Министерство науки и высшего образования Российской Федерации

Российская академия наук

Кольский научный центр

Мурманский морской биологический институт
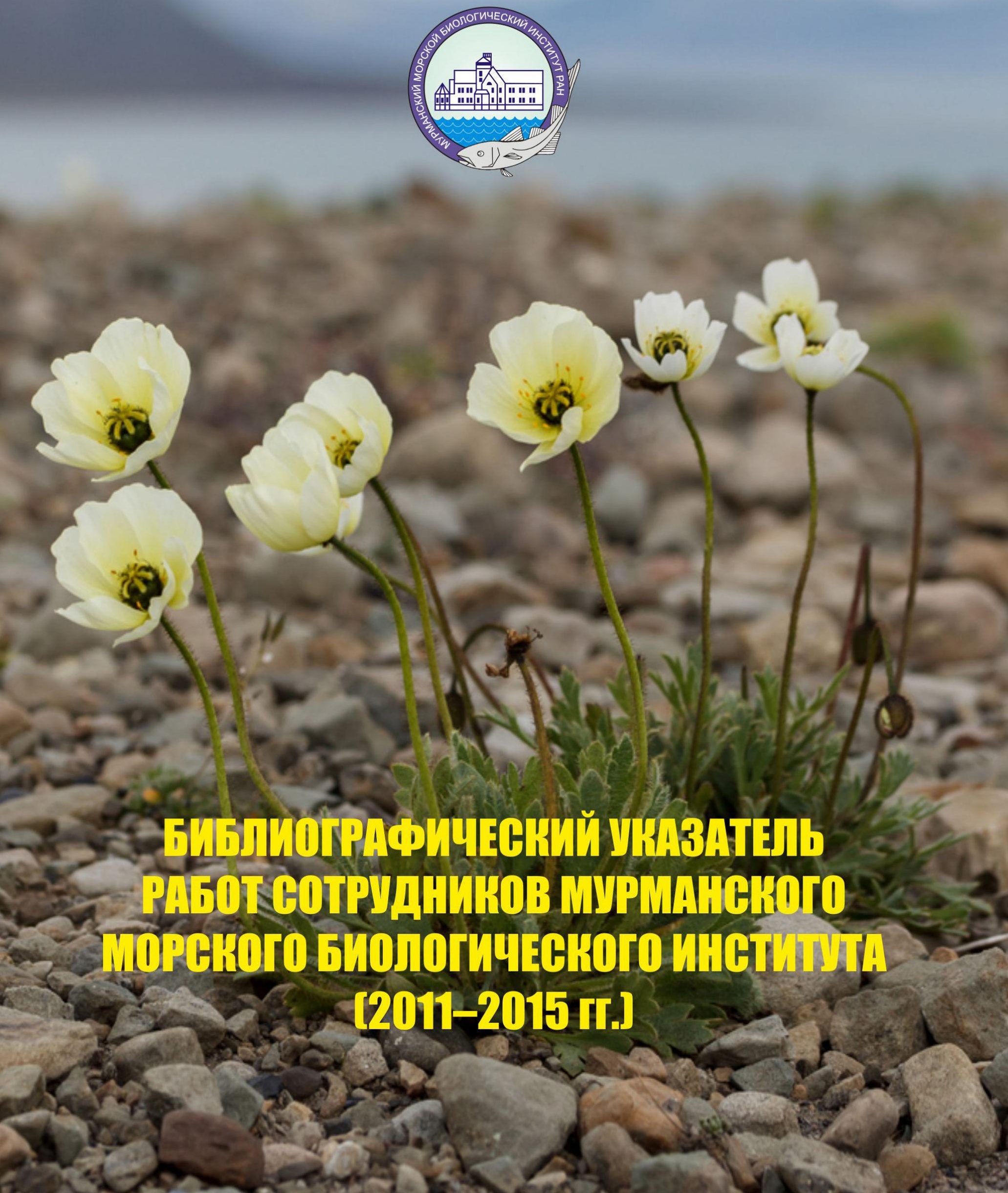
Министерство науки и высшего образования Российской Федерации

Российская академия наук

Кольский научный центр

Мурманский морской биологический институт

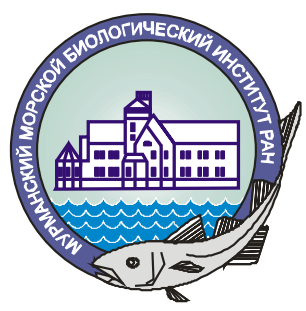

БИБЛИОГРАФИЧЕСКИЙ УКАЗАТЕЛЬ

РАБОТ СОТРУДНИКОВ МУРМАНСКОГО МОРСКОГО БИОЛОГИЧЕСКОГО ИНСТИТУТА

(2011-2015 гг.)

Апатиты

2020 
Библиографический указатель работ сотрудников Мурманского морского биологического института (2011-2015 гг.) / Мурман. мор. биол. ин-т Кольского науч. центра РАН. - Апатиты: Изд-во КНЦ РАН, 2020. $235 \mathrm{c}$

ISBN 978-5-91137-420-4

Настоящий выпуск продолжает издание библиографического указателя работ сотрудников Института, посвященных исследованиям в области геологии, гидрологии, метеорологии, биологии, экологии и охраны окружающей среды. Хронологические рамки зафиксированной в указателе литературы 2011-2015 гг. Все описанные работы систематизированы по темам, в пределах каждого раздела и подраздела расположены в алфавитном порядке. Нумерация статей сквозная. Для удобства пользователей пособие заканчивается авторским указателем.

Составители: Ю.И. Ивакина, Н.Е. Касаткина

ISBN 978-5-91137-420-4 Фе Федеральное государственное бюджетное учреждение науки Мурманский морской биологический институт КНЦ РАН, 2020 
Ministry of Science and Higher Education of the Russian Federation

Russian Academy of Sciences

Kola Science Centre

Murmansk Marine Biological Institute

\section{BIBLIOGRAPHIC INDEX OF THE RESEARCHERS \\ WORKS OF MURMANSK MARINE \\ BIOLOGICAL INSTITUTE \\ (2011-2015)}


DOI: $10.37614 / 978.5 .91137 .420 .4$

Bibliographic index of the researchers works of Murmansk Marine Biological Institute (2011-2015) / Murmansk Marine Biological Institute KSC RAS. - Apatity: Publ. Kola Science Centre RAS, 2020. - 235 p.

ISBN 978-5-91137-420-4

The present release continues the edition of a bibliographic index of works of the Institute devoted to researches in the field of geology, hydrology, meteorology, biology, ecology and environmental protection. Chronological limits of the literature listed in the index are 2011-2015. All described works are systematized on themes, and located in alphabetic order within the frameworks of each section and subsection. Numeration of articles is through. For users' convenience there's author's index at the end of a book.

Compilers: J.I. Ivakina, N.E. Kasatkina

ISBN 978-5-91137-420-4 C Murmansk Marine Biological Institute KSC RAS, 2020 


\section{ИСТОРИЯ ИССЛЕДОВАНИЙ. ЮБИЛЕЙНЫЕ ДАТЫ}

1. Адров Н.М. Морские биологи - физике океана // Вестн. Кольского науч. центра РАН. - 2012. - № 4(11). - С. 62-76.

2. Адров Н.М. Полярная наука Книповича (к 150-летию со дня его рождения). - Апатиты: Изд-во КНЦ РАН, 2012. - 253 с.

3. Адров Н.М. Полярные вызовы Н.М. Книповича // Вестн. Мурм. гос. техн. ун-та. -2012 . - Т. 15, № 4. - С. 858-861.

4. Адров Н.М. Северный период деятельности Н.М. Книповича // Материалы XXX юбилейной конференции молодых ученых Мурманского морского биологического института, посвященной 150летию со дня рождения Н.М. Книповича «Проблемы океанографии, биологии и освоения биоресурсов морей российской Арктики» (г. Мурманск, май 2012 г.). - Мурманск: Изд. ММБИ КНЦ РАН, 2012. - C. 5-9.

5. Адров Н.М. Дерюгинские рубежи морской биологии (к 135летию со дня рождения К.М. Дерюгина). - Мурманск: Изд. ММБИ КНЦ РАН, 2013. - $164 \mathrm{c}$.

6. Адров Н.M. Дерюгинский период морской науки и высшего образования. Ч. 1 // Материалы XXXI конференции молодых ученых Мурманского морского биологического института, посвященной 135летию со дня рождения К.М. Дерюгина, «Океанография и биология арктических морей» (г. Мурманск, май 2013 г.). - Мурманск: Изд. ММБИ КНЦ РАН, 2013. - С. 5-8.

7. Адров Н.M. Дерюгинский период морской науки и высшего образования. Ч. 2 // Материалы XXXI конференции молодых ученых Мурманского морского биологического института, посвященной 135летию со дня рождения К.М. Дерюгина, «Океанография и биология арктических морей» (г. Мурманск, май 2013). - Мурманск: Изд. ММБИ КНЦ РАН, 2013. - С. 188-194.

8. Адров Н.М. Морские биологи - химии океана // Вестн. Кольского науч. центра РАН. - 2013. - № 2(13). - С. 26-35.

9. Адров Н.М. Полянский и Камшилов в Дальних Зеленцах (эссе о рыцарях науки и ее изгнанниках) // Эколого-эволюционные исследования морских организмов и экосистем: Матер. XIV Междунар. науч. конф. студентов и аспирантов «Проблемы Арктического региона» (Мурманск, май 2014 г.). Т. І. Форум молодых ученых, посвященный 110-летию со дня рождения Ю.И. Полянского 
(XXXII конференция молодых ученых ММБИ). - Мурманск: Изд. ММБИ КНЦ РАН, 2014. - С. 5-10.

10. Адров Н.М. Прошлое и будущее глазами пионера Арктики ММБИ // Арктическое морское природопользование в XXI веке современный баланс научных традиций и инноваций (к 80-летию ММБИ КНЦ РАН): Тез. докл. Междунар. науч. конф. (г. Мурманск, 1-3 апреля 2015 г.). - Апатиты: Изд-во КНЦ РАН, 2015. - С. 7-8.

11. Воскобойников Г.М. Альгологические исследования морей русской Арктики // Водоросли: проблемы таксономии, экологии и использование в мониторинге: Матер. докл. III Междунар. науч.-практ. конф. - Ярославль: Изд. Ин-та биол. внутр. вод им. И.Д. Папанина, 2014. - C. 39-41.

12. Денисов В.В., Жичкин А.П. Научное наследие Н.М. Книповича в современных условиях комплексного освоения природных ресурсов Баренцева моря // Вестн. Мурм. гос. техн. ун-та. - 2012. - Т. 15, № 4. C. 721-732.

13. Журавлева Н.Г. К 15-летнему юбилею кафедры биоэкологии // Современные проблемы экологии и природопользования: Сб. матер. регион. науч.-практ. конф., посвященной 15-летию со дня основания кафедры биоэкологии, Мурманск, 27-28 февраля 2014 г. - Мурманск: Изд-во Мурм. гос. техн. ун-та, 2014. - С. 8-12.

14. Зензеров В.C. Мурманскому морскому биологическому институту - 80. Роль ММБИ КНЦ РАН в укреплении приоритета российской науки в Арктике // Вестн. Кольского науч. центра РАН. 2015. - № 2(21). - C. 4-10.

15. Зензеров В.С., Ишкулов Д.Г. Мурманскому морскому биологическому институту Кольского научного центра РАН 75 лет // Океанология. - 2011. - Т. 51, № 6. - С. 1135-1136.

16. Кавиееви Н.Н., Ерохина И.А. 30 лет исследований морских млекопитающих в ММБИ // Арктическое морское природопользование в XXI веке - современный баланс научных традиций и инноваций (к 80-летию ММБИ КНЦ РАН): Тез. докл. Междунар. науч. конф. (г. Мурманск, 1-3 апреля 2015 г.). - Апатиты: Изд-во КНЦ РАН, 2015. C. 92-94.

17. Ковблюк Н.М., Лебедева Н.В., Михайлов К.Г. Александру Викторовичу Пономареву - 60 лет // Arthropoda Selecta. - 2012. № 21(4). - C. 387-396.

18. Лебедева Н.В. Южный вектор арктической морской науки (к 80-летию Мурманского морского биологического института) // Вестн. Южного науч. центра РАН. - 2015. - Т. 11, № 1. - С. 105-106. 
19. Макаревич П.Р., Тарасов Г.А. 35 лет на просторах арктических вод // Вестн. Кольского науч. центра РАН. - 2014. - № 3(18). - С. $26-29$.

20. Матишов Г.Г., Ишкулов Д.Г. Научно-исследовательская и экспедиционная деятельность ММБИ в 2005-2009 годах // Комплексные исследования больших морских экосистем России. - Апатиты: Изд-во КНЦ РАН, 2011. - С. 5-14.

21. Матишов Г.Г., Ковалева Г.В. Николай Михайлович Книпович: биография и научное наследие // Экологическая безопасность приморских регионов (порты, берегозащита, рекреация, марикультура): Матер. Междунар. науч. конф., посвященной 150-летию Н.М. Книповича (Ростов-на-Дону, 5-8 июня 2012 г.). - Ростов н/Д.: Изд-во ЮНЦ РАН, 2012. - С. 5-15.

22. Матишов Г.Г., Степаньян О.В. Научно-исследовательское судно «Профессор Панов»: 10 лет морских экспедиционных исследований // Вестн. Южного науч. центра РАН. - 2012. - Т. 8, № 2. - С. 91-93.

23. Матишов Г.Г., Степаньян О.В. Научно-исследовательское судно «Денеб»: 5 лет морских экспедиционных исследований // Вестн. Южного науч. центра РАН. - 2012. - Т. 8, № 3. - С. 92-95.

24. Матишов Г.Г., Степаньян О.В. Морские исследования у берегов Абхазии // Природа. - 2014. - № 11. - С. 70-78.

25. Чинарина А.Д. Герман Августович Клюге (жизнь, организациионная и научная деятельность) // Материалы XXIX конференции молодых ученых Мурманского морского биологического института, посвященной 140 -летию со дня рождения Г.А. Клюге, «Морские исследования экосистем европейской Арктики» (г. Мурманск, май 2011 г.). - Мурманск: Изд. ММБИ КНЦ РАН, 2011. - С. 5-8.

26. Чинарина А.Д. «Смотреть вперед и помнить...». Очерки из истории ММБИ КНЦ РАН. - Ростов н/Д.: Изд-во ЮНЦ РАН, 2012. - 326 с.

27. Чинарина А.Д. Памяти Владимира Матвеевича Муравейко (1944-2014) // Арктическое морское природопользование в XXI веке современный баланс научных традиций и инноваций (к 80-летию ММБИ КНЦ РАН): Тез. докл. Междунар. науч. конф. (г. Мурманск, 1-3 апреля 2015 г.). - Апатиты: Изд-во КНЦ РАН, 2015. - С. 245-247.

28. Чинарина А.Д., Ивакина Ю.И. Мурманский морской биологический институт в 1981-2011 гг. (к 30-летию руководства Институтом академиком Г.Г. Матишовым). - Мурманск: Изд. ММБИ КНЦ РАН, 2011. - 58 с. 


\section{ГЕОЛОГИЯ. СЕДИМЕНТОЛОГИЯ. ПАЛЕОЭКОЛОГИЯ}

29. Геологическое строение Западно-Шпицбергенской континентальной окраины / Г.С. Казанин, Г.А. Тарасов, Т.Я. Федухина, B.B. Шлькова // Комплексные исследования природы Шпицбергена и прилегающего шельфа: Матер. Междунар. науч. конф. (Мурманск, 6-8 ноября 2014 г.). Вып. 12. - М.: ГЕОС, 2014. - С. 132-143.

30. Герасимова М.В., Митяев М.В. Взвешенное вещество в губе Чупа, Карельское побережье Белого моря // Проблемы изучения, рационального использования и охраны природных ресурсов Белого моря: Матер. XII Междунар. конф. с элементами школы для молодых ученых и аспирантов (Петрозаводск, 30 сентября-4 октября 2013 г.). Петрозаводск: Изд-во КарелНЦ РАН, 2013. - С. 91-94.

31. Герасимова М.В., Митяев М.В. Современные условия осадконакопления в проливах архипелага ЗФИ // Геология морей и океанов: Матер. XX Междунар. науч. конф. (Школы) по морской геологии (г. Москва, 18-22 ноября 2013 г.). Т. І. - М.: ГЕОС, 2013. - С. 44-48.

32. Герасимова М.В., Митяев М.В. Физические свойства вещества, осаждающегося на дно и формирующего первичный слой отложений в губах Мурманского побережья // Геология морей и океанов: Матер. XXI Междунар. науч. конф. (Школы) по морской геологии. Т. III. - М.: ГЕОС, 2015. - С. 14-16.

33. Детальная реконструкция изменения палеосреды северо-востока Белого моря в позднезаальское-эемское время / E.E. Талденкова, Х.А. Баух, А.Ю. Степанова, Я.С. Овсепян, О.В. Руденко, И.А. Погодина, С.Д. Николаев // Квартер во всем его многообразии. Фундаментальные проблемы, итоги изучения и основные направления дальнейших исследований: Матер. VII Всерос. совещ. по изучению четвертичного периода (г. Апатиты, 12-17 сентября 2011 г.). - Апатиты; СПб.: Б.и., 2011. - T. 2. - С. 260-263.

34. Западно-Шпицбергенская континентальная окраина: геологическое строение, нефтегазоносность / Г.С. Казанин, Г.А. Тарасов, Т.Я. Федухина, В.В. Шлькова, Г.Г. Матишов // Докл. РАН. - 2015. T. 460, № 2. - C. 204-209.

35. К вопросу о реконструкции палеоландшафтных особенностей Нижнего Подонья в финальный период эпохи бронзы-раннем железном веке / Г.В. Ковалева, К.В. Красноручкая, М.В. Набоженко, В.В. Польшин, B.B. Потапов, И.В. Толочко // Культуры степной Евразии и их взаимодействие с древними цивилизациями: Матер. Междунар. конф. (Санкт-Петербург, 22-26 октября 2012 г.). - СПб.: ИИМК РАН, Периферия, 2012. - Кн. 1. - С. 405-414. 
36. Кокин O.B. Геолого-геоморфологическая деятельность пульсирующих ледников // Вестн. Моск. гос. ун-та. Сер. Геогр. 2011. - № 1. - С. 22-27.

37. Кокин O.B. Геоморфологический анализ при реконструкции палеопульсаций горно-долинных ледников // Рельеф и экзогенные процессы гор. - Иркутск: Изд. Ин-та геогр. им. В.Б. Сочавы СО РАН, 2011. - T. 2. - C. 25-26.

38. Кокин O.B. Голоценовые стадии оледенения Западного Шпицбергена // Квартер во всем его многообразии. Фундаментальные проблемы, итоги изучения и основные направления дальнейших исследований: Матер. VII Всерос. совещ. по изучению четвертичного периода (г. Апатиты, 12-17 сентября 2011 г.). - Апатиты; СПб.: Б.и., 2011. - Т. 1. - С. 274-275.

39. Кокин O.B. Сравнительный анализ рельефа подводного продолжения горных долин Западного Шпицбергена при реконструкции истории их развития // Материалы XXIX конференции молодых ученых Мурманского морского биологического института, посвященной 140-летию со дня рождения Г.А. Клюге, «Морские исследования экосистем европейской Арктики» (г. Мурманск, май 2011 г.). - Мурманск: Изд. ММБИ КНЦ РАН, 2011. С. 104-105.

40. Костин Д.А., Тарасов Г.А. Четвертичный осадочный чехол Баренцево-Карского бассейна // Геология и геоэкология континентальных окраин Евразии. Вып. 3. Специальное издание, посвященное 40-летию МАГЭ. - М.: ГЕОС, 2011. - 107-130 с.

41. Матишов Г.Г., Калмыков Н.П. Ассоциация Anancus archidiskodon (Mammalia, Proboscidea) в биомах юга Русской платформы // Вестн. Южного науч. центра РАН. - 2011. - Т. 7, № 1. - С. 65-70.

42. Матишов Г.Г., Калмыков Н.П. Дейнотерии (Mammalia, Proboscidea) в позднетретичных биомах Восточной Европы // Вестн. Южного науч. центра РАН. - 2012. - Т. 8, № 1. - С. 47-53.

43. Матишов Г.Г., Калмыков Н.П. Представления об истории современных ландшафтов Ергениской возвышенности и Ставропольского выступа // Вестн. Южного науч. центра РАН. - 2013. - Т. 9, № 2. C. 32-37.

44. Матишов Г.Г., Парада С.Г. Добыча сланцевого газа методом гидроразрыва пласта: современное состояние, риски и угрозы // Геология и геофизика Юга России. - 2015. - № 1. - С. 42-60.

45. Матишов Г.Г., Шипилов Э.В. Минеральные ресурсы морских шельфов // Богатства России. - М.: Календа, 2012. - С. 208-211. 
46. Матишов Г.Г., Калмыков Н.П., Климук В.С. Новые данные о фауне и стратиграфии местонахождения Семибалки (Приазовье) // Докл. РАН. - 2012. - Т. 442, № 5. - С. 664-667.

47. Матишов Г.Г., Новенко Е.Ю., Дюжсова К.В. Палиноиндикация антропогенных изменений растительности Приазовья (по данным изучения донных отложений Азовского моря) // Докл. РАН. - 2013. Т. 450, № 6. - С. 708-712.

48. Матишов Г.Г., Новенко Е.Ю., Красноруичкая К.В. Динамика ландшафтов Приазовья в позднем голоцене // Вестн. Южного науч. центра РАН. - 2011. - Т. 7, №3. - С. 35-43.

49. Матишов Г.Г., Новенко Е.Ю., Красноруцкая К.В. Изменения климата Приазовья в позднем голоцене // Докл. РАН. - 2012. - Т. 444, № 3. - С. 320-324.

50. Матишов Г.Г., Польшин В.В., Толочко И.В. К вопросу о реконструкции береговой линии Таганрогского залива и дельты Дона в античную эпоху // Экологическая безопасность приморских регионов (порты, берегозащита, рекреация, марикультура): Матер. Междунар. науч. конф., посвященной 150-летию Н.М. Книповича (Ростов-на-Дону, 5-8 июня 2012 г.). - Ростов н/Д.: Изд-во ЮНЦ РАН, 2012. - С. 147-156.

51. Мешеряков Н.И. Закономерности седиментационных процесссов в береговых перигляционных областях залива Грён-фьорд (Западный Шпицберген) // Комплексные исследования природы Шпицбергена: Матер. Междунар. науч. конф. (Мурманск, 1-3 ноября 2012 г.). Вып. 11. - М.: ГЕОС, 2012. - C. 179-185.

52. Мещеряков Н.И. Морфометрические особенности и геоморфологический облик залива Грён-фьорд // Материалы XXX юбилейной конференции молодых ученых Мурманского морского биологического института, посвященной 150-летию со дня рождения Н.М. Книповича, «Проблемы океанографии, биологии и освоения биоресурсов морей российской Арктики» (г. Мурманск, май 2012). - Мурманск: Изд. ММБИ КНЦ РАН, 2012. - С. 126-129.

53. Мещеряков Н.И. Изучение ледового переноса осадочного вещества в заливе Грён-фьорд // Геология морей и океанов: Матер. XX Междунар. науч. конф. (Школы) по морской геологии (г. Москва, 18 22 ноября 2013 г.). T. III. - М.: ГЕОС, 2013. - С. 54-58.

54. Мещеряков Н.И. Накопление и перераспределение осадочного материала в устьевой зоне реки Грёндален (Западный Шпицберген) // Вестн. Мурм. гос. техн. ун-та. - 2013. - Т. 16, № 3. - С. 501-505.

55. Мешеряков Н.И. Некоторые особенности перераспределения осадков в береговой зоне Грён-фьорд (Западный Шпицберген) // Материалы XXXI конференции молодых ученых Мурманского морского 
биологического института, посвященной 135 -летию со дня рождения К.М. Дерюгина, «Океанография и биология арктических морей» (г. Мурманск, май 2013). - Мурманск: Изд. ММБИ КНЦ РАН, 2013. C. $136-139$.

56. Мещеряков Н.И. Некоторые вопросы формирования зандровой равнины в верховье залива Грён-фьорд (Западный Шпицберген) // Вестн. Мурм. гос. техн. ун-та. - 2014. - Т. 17, № 1. - С. 153-156.

57. Мещеряков Н.И. Структурные особенности песчаной косы залива Грён-фьорд (Западный Шпицберген) // Эколого-эволюционные исследования морских организмов и экосистем: Матер. XIV Междунар. науч. конф. студентов и аспирантов «Проблемы Арктического региона» (г. Мурманск, май 2014 г.). Т. І. Форум молодых ученых, посвященный 110-летию со дня рождения Ю.И. Полянского (XXXII конференция молодых ученых ММБИ). - Мурманск: Изд. ММБИ КНЦ PAH, 2014. - C. 113-115.

58. Мещеряков Н.И. Особенности геоморфологии подводной равнины устьевой зоны реки Грёндален (Западный Шпицберген) // Арктическое морское природопользование в XXI веке - современный баланс научных традиций и инноваций (к 80-летию ММБИ КНЦ РАН): Тез. докл. Междунар. науч. конф. (г. Мурманск, 1-3 апреля 2015 г.). Апатиты: Изд-во КНЦ РАН, 2015. - С. 162-163.

59. Мещеряков Н.И., Бобров К.А., Тарасов Г.А. Седиментологические и океанологические исследования в апреле 2014 года в заливе Грён-фьорд // Комплексные исследования природы Шпицбергена и прилегающего шельфа: Матер. Междунар. науч. конф. (Мурманск, 6-8 ноября 2014 г.). Вып. 12. - М.: ГЕОС, 2014. - С. 210-215.

60. Митяев M.В. Древнебереговые линии Мурманского побережья // Квартер во всем его многообразии. Фундаментальные проблемы, итоги изучения и основные направления дальнейших исследований: Матер. VII Всерос. совещ. по изучению четвертичного периода (г. Апатиты, 12-17 сентября 2011 г.). - Апатиты; СПб.: Б.и., 2011. - Т. 2. - C. 89-91.

61. Митяев М.В. Древние береговые линии островов архипелага ЗФИ // Геология морей и океанов: Матер. XX Междунар. науч. конф. (Школы) по морской геологии (г. Москва, 18-22 ноября 2013 г.). T. V. М.: ГEOC, 2013. - C. 193-198.

62. Митяев М.В. Мурманское побережье (геолого-геоморфологические и климатические особенности, современные геологические процессы). Апатиты: Изд-во КНЦ РАН, 2014. - 226 с.

63. Митяев М.В. Морфоструктурное строение архипелага ЗФИ // Геология морей и океанов: Матер. XX Междунар. науч. конф. (Школы) 
по морской геологии (г. Москва, 18-22 ноября 2013 г.). Т. V. - М.: ГЕОС, 2013. - С. 310-313.

64. Митяев М.В., Бергер В.Я. Сезонная изменчивость концентрации водной взвеси в губе Чупа (Белое море) // Океанология. 2014. - Т. 54, № 3. - С. 368-377.

65. Митяев М.В., Герасимова М.В. Вертикальные потоки вещества в заливах Мурманского и Карельского побережий // Квартер во всем его многообразии. Фундаментальные проблемы, итоги изучения и основные направления дальнейших исследований: Матер. VII Bсерос. совещ. по изучению четвертичного периода (г. Апатиты, 12-17 сентября 2011 г.). - Апатиты; СПб.: Б.и., 2011. - Т. 2. - С. 92-95.

66. Митяев М.В., Герасимова М.В. Пространственно-временные изменения концентрации взвешенного вещества в заливах Мурманского и Карельского побережий // Геология океанов и морей: Матер. XIX Междунар. научн. конф. (Школы) по морской геологии (г. Москва, 14-18 ноября 2011 г.). Т. III. - М.: ГЕОС, 2011. - С. 48-52.

67. Митяев M.B., Герасимова М.В. Суточные изменения содержания взвеси в губах Чупа (Белое море) и Ярнышная (Баренцево море) // Глобальные климатические процессы и их влияние на экосистемы арктических и субарктических регионов: Тез. докл. Междунар. науч. конф. (г. Мурманск, 9-11 ноября 2011 г.). - Апатиты: Изд-во КНЦ РАН, 2011. - С. 129-131.

68. Митяев М.В., Герасимова М.В. Динамика вод и взвеси в губе Чупа Карельского побережья Белого моря в зависимости от стадии приливоотливного цикла // Морская биология, геология, океанология междисциплинарные исследования на морских стационарах: Матер. науч. конф., посвященной 75-летию Беломорской биологической станции им. Н.А. Перцова (г. Москва, 27 февраля-1 марта 2013). М.: Тов-во науч. изд. КМК, 2013. - С. 196-201.

69. Митяев М.В., Герасимова М.В. Позднечетвертичная история осадконакопления в проливах архипелага ЗФИ // Геология морей и океанов: Матер. XX Междунар. науч. конф. (Школы) по морской геологии (г. Москва, 18-22 ноября 2013 г.). Т. І. - М.: ГЕОС, 2013. C. 105-108.

70. Митяев М.В., Герасимова М.В. Геолого-тектонические, геоморфологические особенности строения и современные условия седиментации архипелага Земля Франца-Иосифа // Тр. Кольского науч. центра РАН. - 2014. - Т. 4(23). - Сер. Океанология. - Вып. 2.- С. 5-60.

71. Митяев М.В., Герасимова М.В. Изменение интенсивности экзогенных геологических процессов на Мурманском побережье // 
Эволюция осадочных процессов в истории Земли: Матер. 8-го Всерос. литологического совещ. (Москва, 27-30 октября 2015 г.). - М.: Изд-во РГУ нефти и газа им. И.М. Губкина, 2015. - Т. 1. - С. 125-126.

72. Митяев М.В., Герасимова М.В. Цикличность экзогенных геологических процессов на Мурманском побережье // Арктическое морское природопользование в XXI веке - современный баланс научных традиций и инноваций (к 80-летию ММБИ КНЦ РАН): Тез. докл. Междунар. науч. конф. (г. Мурманск, 1-3 апреля 2015 г.). Апатиты: Изд-во КНЦ РАН, 2015. - С. 165.

73. Митяев М.В., Бергер В.Я., Герасимова М.В. Взвесь и вертикальные потоки осадочного вещества в губе Чупа (Карельское побережье) // Геология морей и океанов: Матер. XXI Междунар. науч. конф. (Школы) по морской геологии. Т. III. - М.: ГЕОС, 2015. - С. 65-69.

74. Митяев М.В., Герасимова М.В., Бергер В.Я. Взвесь и вертикальные потоки осадочного вещества в губе Ярнышная (Мурманское побережье) и губе Чупа (Карельское побережье) // Геология морей и океанов: Матер. ХХ Междунар. науч. конф. (Школы) по морской геологии (г. Москва, 18-22 ноября 2013 г.). Т. III. - М.: ГЕОС, 2013. - С. 59-63.

75. Митяев М.В., Герасимова М.В., Бергер В.Я. Взвесь и вертикальные потоки осадочного вещества в губе Ярнышная (Мурманское побережье) // Геология морей и океанов: Матер. XXI Междунар. науч. конф. (Школы) по морской геологии. Т. III. - М.: ГЕОС, 2015. - C. 60-64.

76. Митяев М.В., Герасимова М.В., Дружскова Е.И. Вертикальные потоки осадочного вещества в прибрежных районах Баренцева и Белого морей // Океанология. - 2012. - Т. 52, № 1. - С. 121-130.

77. Нижнее Подонье в эпоху поздней бронзы и раннего железа: палеогеографические реконструкции / Г.Г. Матишов, И.В. Толочко, В.В. Потапов, М.В. Набоженко, В.В. Польиин, К.В. Дюжова, Г.В. Ковалева, A.E. Золотарева // Вестн. Южного науч. центра РАН. - 2013. - Т. 9, № 4. - C.56-65.

78. Погодина И.А. Фораминиферы в донных отложениях морей Западной Арктики. - Апатиты: Изд-во КНЦ РАН, 2014. - 192 с.

79. Развитие шельфовых экосистем Арктики в условиях морского перигляциала / Г.Г. Матишов, В.В. Денисов, С.Л. Дженюк, П.Р. Макаревич, И.А. Погодина, Г.А. Тарасов // Физические, геологические и биологические исследования океанов и морей. - М.: Научный мир, 2010. - С. 598-612. 
80. Руденко О.В., Тарасов Г.А. Изменения природной среды Северо-Канинского региона в голоцене (по палинологическим данным) // Вестн. Южного науч. центра РАН. - 2012. - Т. 8, № 1. - С. 38-46.

81. Тарасов Г.А. Потоки осадочного вещества в заливе Грёнфьорд // Квартер во всем его многообразии. Фундаментальные проблемы, итоги изучения и основные направления дальнейших исследований: Матер. VII Всерос. совещ. по изучению четвертичного периода (г. Апатиты, 12-17 сентября 2011 г.). - Апатиты; СПб.: Б.и., 2011. - Т. 2. - С. 263-265.

82. Тарасов Г.А. Быстроменяющийся гляциально-перигляциальный ландшафт Западного Шпицбергена // Комплексные исследования природы Шпицбергена: Матер. Междунар. науч. конф. (Мурманск, 1-3 ноября 2012 г.). Вып. 11. - М.: ГЕОС, 2012. - С. 232-238.

83. Тарасов Г.А. Новые представления о суточной изменчивости потока осадочного вещества в фьордовом заливе Шпицбергена // Геология морей и океанов: Матер. ХХ Междунар. науч. конф. (Школы) по морской геологии (г. Москва, 18-22 ноября 2013 г.). Т. III. - М.: ГЕОС, 2013. - С. 97-102.

84. Тарасов Г.А. Особенности седиментологических исследований в Арктике // Тр. Кольского науч. центра РАН. - 2013. - Т. 1(14). - Сер. Океанология. - Вып.1. - С. 79-95.

85. Тарасов Г.А. Грён-фьорд под натиском тепла // Рус. вестн. Шпицбергена. - 2014. - № 10. - С. 20.

86. Тарасов Г.А. К вопросу о седиментологической роли полихет в заливах Шпицбергена // Комплексные исследования природы Шпицбергена и прилегающего шельфа: Матер. Междунар. науч. конф. (Мурманск, 6-8 ноября 2014 г.). Вып. 12. - М.: ГЕОС, 2014. - С. 287-290.

87. Тарасов Г.А. К природе малоизвестных природных процессов влияющих на ход современного седиментогенеза // Евразийское научное объединение. - 2015. - Т. 2, № 11(11). - С. 154-156.

88. Тарасов Г.А. Процессы седиментации и геологические этапы развития шельфа Баренцева моря // Арктическое морское природопользование в XXI веке - современный баланс научных традиций и инноваций (к 80-летию ММБИ КНЦ РАН): Тез. докл. Междунар. науч. конф. (г. Мурманск, 1-3 апреля 2015 г.). - Апатиты: Изд-во КНЦ РАН, 2015. C. 223-224.

89. Тарасов Г.А. Четвертичный осадочный чехол ЗападноАрктического шельфа: литологическое строение, пространственное распределение // Вестн. Кольского науч. центра РАН. - 2015. № 2(21). - C. 124-134. 
90. Тарасов Г.А., Мещеряков Н.И. Ледовый режим и процессы осадкообразования в заливах Шпицбергена // Геология морей и океанов: Матер. XXI Междунар. науч. конф. (Школы) по морской геологии. T. IV. - М.: ГЕОС, 2015. - С. 319-323.

91. Тарасов Г.А., Руденко О.В., Матишов Г.Г. Палиностратиграфия голоцена Чёшской губы Баренцева моря как инструмент реконструкции природной среды // Докл. РАН. - 2011. - Т. 439, № 4. - С. 545-547.

92. Шипилов Э.В. Геодинамика суперплюмовых событий в эволюции Арктического океана и его континентальных окраин // Современное состояние наук о Земле: Матер. Междунар. конф., посвященной памяти В.Е. Хаина (Москва, 1-4 февраля 2011 г.). - М.: Изд-во Моск. гос. ун-та, 2011. - С. 2110-2113.

93. Шипилов Э.В. О позднемезозойском вулканизме ВосточноАрктической континентальной окраины Евразии (Восточно-Сибирское море) по сейсмическим данным // Докл. РАН. - 2011. - Т. 436, № 4. C. 504-508.

94. Шипилов Э.В., Карякин Ю.В. Баренцевоморская магматическая провинция: геолого-географические свидетельства и новые результаты определения ${ }^{40} \mathrm{Ar} /{ }^{39} \mathrm{Ar}-$ возраста // Докл. РАН. - 2011. - Т. 439, № 3. С. $376-382$.

95. Шипилов Э.В., Карякин Ю.В. Баренцевоморская мезозойская магматическая провинция: строение и ${ }^{40} \mathrm{Ar} /{ }^{39} \mathrm{Ar}$-возраст // Вулканизм и геодинамика: Матер. V Всерос. симп. по вулканологии и палеовулканологии. Екатеринбург: Изд. Ин-та геологии и геохимии УрО РАН, 2011. C. $396-400$.

96. Шипилов Э.В., Карякин Ю.В. О мезозойской магматической провинции на баренцевоморском обрамлении Балтийского щита: строение, ${ }^{40} \mathrm{Ar} /{ }^{39} \mathrm{Ar}-$ возраст и геодинамика формирования // Минералогия, петрология и полезные ископаемые Кольского региона. Труды VIII Всероссийской (с международным участием) Ферсмановской научной сессии, посвященной 135-летию со дня рождения академика Д.С. Белянкина (18-19 апреля 2011 г.). - Апатиты: Изд-во К\&М, 2011. С. 218-225.

97. Шипилов Э.В., Шкарубо С.И. Новые данные о структуре комплексов основания Южно-Карского бассейна // Докл. РАН. - 2011. T. 438, № 1. - C. 95-100.

98. Шипилов Э.В., Шкарубо С.И. Строение домезозойского основания Южно-Карского сегмента Западно-Сибирской плиты // Разведка и охрана недр. - 2012. - № 1. - С. 38-42. 
99. Benthic community changes at the North Siberian margin in response to Atlantic water mass variability since last deglacial times / E. Taldenkova, H.A. Bauch, A.Yu. Stepanova, Ya. Ovsepyan, I. Pogodina, T. Klyuvitkina, S. Nikolaev // Marine Micropaleontology. - 2012. - Vol. 96-97. P. 13-28. - URL: http://www.sciencedirect.com/science/article/pii/S0377839812000618

100. Benthic community changes at the North Siberian margin in response to Atlantic water mass variability since last deglacial times / E. Taldenkova, H.A. Bauch, A. Stepanova, Ya. Ovsepyan, I. Pogodina, T. Klyuvitkina, S. Nikolaev // Marine Micropaleontology. - 2013. - Vol. 99. (Arctic Ocean Warming of the Past: Proxy Development and Reconstructions). - P. 29-44.

101. Early stages of evolution of the Arctic margins (NeoproterozoicPaleozoic) and plate reconstructions / V.A. Vernikovsky, D.V. Metelkin, A.E. Vernikovskaya, N.Yu. Matushkin, L.I. Lobkovsky, E.V. Shipilov // Abstract book the VI International conference on Arctic margins (ICAM-VI) (31 May-2 June 2011, Fairbanks, Alaska, USA). - Fairbanks: University of Alaska, 2011. - P. 224.

102. History of ice-rafting and water mass evolution at the North Siberian continental margin (Laptev Sea) during Late Glacial and Holocene times / E. Taldenkova, H.A. Bauch, J. Gottschalk, S. Nikolaev, Yu. Rostovtseva, I. Pogodina, Ya. Ovsepyan, E. Kandiano // Quaternary Sci. Rev. - 2010. Vol. 29. - P. 3919-3935.

103. Kazanin G.S., Tarasov G.A. The geological structure and petroleum resource potential of the West Spitsbergen continental margin // Petrochemistry and Chemical Engineering: Abstr. of $3^{\text {rd }}$ World Congress (November 30 December 02, 2015, Atlanta, USA). - 2015. - Vol. 6, Iss. 5. - P. 75.

104. Kokin $O$. The evidences of the Pre-Holocene glacier advance in West Spitsbergen // Arctic Palaeoclimate and its Extremes (APEX): V Intern. Conf. and Workshop. - Longyearbyen, Svalbard, 2011. - P. 84-85.

105. Late Saalian - Eemian transition: a new high-resolution record of environmental changes from the northeastern White Sea region, northern Russia / E. Taldenkova, H. Bauch, A. Stepanova, Ya. Ovsepyan, O. Rudenko, I. Pogodina // Quaternary sciences - the view from the mountains (XVIII INQUA - 2011) (21-27 July 2011 in Bern, Switzerland). Sess. 17 Interglacial Climates / Poster. ID 2303. - Bern, 2011. - URL: http://www.inqua2011.ch/?a=programme\&subnavi=abstract\&id=2303\&sess ionid=17

106. Paleogeography of the Sea of Azov region in the Late Holocene (reconstruction by diatom and pollen data from marine sediments) / G. Matishov, G. Kovaleva, E. Novenko, K. Krasnorutskaya, V. Pol'shin // 
Quaternary International. - 2012. - P. 1-9. - URL http://dx.doi.org/ 10.1016/j.quaint.2012.05.044

107. Phases and stages of the plume magmatism in the Franz-Josef Land Archipelago / Yu.V. Kariakin, E.V. Shipilov, V.A. Simonov, E.V. Sklyarov, A.V. Travin // Large Igneous Provinces of Asia: Abstr. Intern. Symp. Irkutsk: IEC SB RAS, 2011. - P. 96-98.

108. Postglacial and Holocene environmental evolution of the Laptev Sea continental margin inferred from high-resolution records of benthic and planktic foraminifers / Ya. Ovsepyan, E. Taldenkova, I. Pogodina, H. Bauch // Quaternary sciences - the view from the mountains (XVIII INQUA - 2011) (21-27 July 2011 in Bern, Switzerland) Sess. 17 Interglacial Climates / Poster. ID 2200. - Bern, 2011. - URL: http://www.inqua2011.ch/?a= programme\&subnavi $=$ abstract\& $\mathrm{id}=2200 \&$ sessionid $=17$

109. Rudenko O., Tarasov G. Holocene palynostratigraphy of bottom and marine bench sediments of the Barents Sea Chyosha Bay // Abstract book the VI International conference on Arctic margins (ICAM-VI) (31 May-2 June 2011, Fairbanks, Alaska, USA). - Fairbanks: University of Alaska, 2011. - P. 185-186. - URL: http://www.2.gi.alaska.edu/ICAMVI

110. Shipilov E.V., Karyakin Yu.V. Geodynamics of the JurassicCretaceous basaltoid magmatism of the Arctic region and the origin of the Canadian oceanic basin // Abstract book the VI International conference on Arctic margins (ICAM-VI) (31 May-2 June 2011, Fairbanks, Alaska, USA). - Fairbanks: University of Alaska, 2011. - P. 186-187. - URL: http://www.2.gi.alaska.edu/ICAMVI

111. Tarasov G. Late Quaternary evolution of the Barents Sea // Quaternary sciences - the view from the mountains (XVIII INQUA - 2011) (21-27 July 2011 in Bern, Switzerland). - Bern, 2011. - URL: http://www.inqua2011.ch/?a=programme\&subnavi=sessions\&id=103

112. Tarasov G.A. Sedimentation processes and glacial history in the Western Arctic Ocean // Berichte zur Polarforschung. - 2012. - № 640. - P. 81-100.

113. Tarasov G.A., Mesheriakov N.I. Mass transport and sedimentogenesis in the periglacial of Spitsbergen // Fundamental science and technology promising developments III. - North Charleston, USA, 2014. - Vol. 2. - P. 23-25.

114. The West Spitzbergen continental margin: The geological structure and petroleum resource potential / G.S. Kazanin, G.A. Tarasov, T.Ya. Feduhina, V.V. Schlykova, G.G. Matishov // Doklady Earth Sci. 2015. - Vol. 460, part 1. - P. 22-27.

115. Zakharenko $V$., Paramonova M., Tarasov G. Specific nature of quaternary sedimentation within West Svalbard continental margin // Quaternary sciences - the view from the mountains (XVIII INQUA - 2011) 
(21-27 July 2011 in Bern, Switzerland). - Bern, 2011. - URL: http://www.inqua2011.ch/?a=programme\&subnavi=sessions\&id=103

\section{ГИДРОЛОГИЯ. ГИДРОХИМИЯ. МЕТЕОРОЛОГИЯ}

116. Адров H.M. Природа энерговлагообмена водных и воздушных масс Баренцева моря. - Мурманск: Изд-во Мурм. гос. техн. ун-та, 2012. -75 с.

117. Бардан С.И. Количественный анализ и динамика области смешения морских и материковых вод южного колена Кольского залива (Баренцево море) // Изучение и освоение морских и наземных экосистем в условиях арктического и аридного климата: Матер. Междунар. науч. конф. (6-11 июня 2011 г., Ростов-на-Дону). - Ростов н/Д.: Изд-во ЮНЦ РАН, 2011. - С. 20-24.

118. Бардан С.И. Гидрохимическая характеристика вод архипелага Земля Франца-Иосифа (Баренцево море) и условия их формирования в конце летнего сезона // Изучение и освоение морских и наземных экосистем в условиях арктического и аридного климата: Матер. Междунар. науч. конф. (6-11 июня 2011 г., Ростов-на-Дону). Ростов н/Д.: Изд-во ЮНЦ РАН, 2011. - С. 231-234.

119. Бардан С.И. Облученность и спектральный состав проходящей в толщу вод ФАР на широте Печорского моря для подледного периода // Экологическая безопасность приморских регионов (порты, берегозащита, рекреация, марикультура): Матер. Междунар. науч. конф., посвященной 150-летию Н.М. Книповича (Ростов-на-Дону, 5-8 июня 2012 г.). Ростов н/Д.: Изд-во ЮНЦ РАН, 2012. - С. 47-51.

120. Бардан С.И., Долгоносов Б.М. Физические основы устойчивости слоистых структур области река-море и натурные данные по Кольскому заливу // Вестн. Кольского науч. центра РАН. 2013. - № 2(13). - С. 36-54.

121. Бардан С.И., Корнеева Г.А. Гидролитическая активность водной среды в водах архипелага Земля Франца-Иосифа (Баренцево море) и анализ условий формирования // Изучение и освоение морских и наземных экосистем в условиях арктического и аридного климата: Матер. Междунар. науч. конф. (6-11 июня 2011 г., Ростов-на-Дону). Ростов н/Д.: Изд-во ЮНЦ РАН, 2011. - С. 234-237.

122. Бардан С.И., Разумовский Л.В. Анализ иерархической системы озер Кольского полуострова // Оценка трансформации озерных экосистем методом диатомового анализа. - М.: ГЕОС, 2012. - С. 73-80. 
123. Бардан С.И., Сербов Н.Г. Оптические характеристики зоны смешения морских и пресных вод в южном колене Кольского залива (Баренцево море) в летний сезон // Український гидромет. журн. 2011. - № 9. - С. 210-219.

124. Бардан С.И., Сербов Н.Г. Формулирование и анализ модели влияния температуры на биопродукционный потенциал компонентов фитоценоза в водных экосистемах // Український гидромет. журн. 2013. - № 13. - С. 191-215.

125. Бардан С.И., Сербов Н.Г., Корнеева Г.А. Формы гидролитической активности водной среды и закономерности ее формирования в зимний сезон на примере Печорского моря // Український гидромет. журн. - 2012. - № 10. - С. 181-194.

126. Батиметрические и океанографические факторы формирования БМЭ Арктики / Г.Г. Матишов, С.Л. Дюенюк, А.П. Жичкин, Д.В. Моисеев // Комплексные исследования больших морских экосистем России. Апатиты: Изд-во КНЦ РАН, 2011. - С. 63-91.

127. Бергер В.Я., Митяев М.В. Сезонные и межгодовые изменения концентрации органических веществ в сестоне Белого моря // Вопросы промысловой океанологии. - 2012. - Вып. 9, № 2. - С. 123-124.

128. Бобров K.A. Некоторые результаты исследований водных масс арктических морей с помощью отрывных зондирующих систем // Материалы XXXI конференции молодых ученых Мурманского морского биологического института, посвященной 135-летию со дня рождения К.М. Дерюгина, «Океанография и биология арктических морей» (г. Мурманск, май 2013). - Мурманск: Изд. ММБИ КНЦ РАН, 2013. - C. 33-38.

129. Влияние сейсмичности на распределение рыбных скоплений на западной окраине Баренцевоморского бассейна / A.Н. Виноградов, С. Баранов, А.П. Жичкин, Д.В. Моисеев // Рыбные ресурсы. - 2011. № 2. - C. 18-21.

130. Гаргопа Ю.М. Влияние климатообразующих процессов на биогенные вещества Азовского моря // Вопросы промысловой океанологии. - 2010. - Т. 7, вып. 2. - С. 65-83.

131. Гаргопа Ю.М. Азовское море в условиях климатических изменений и антропогенных воздействий // Азовское море, Керченский пролив и предпроливные зоны в Черном море: проблемы управления прибрежными территориями для обеспечения экологической безопасности и рационального природопользования. - Ростов н/Д.: Изд-во ЮНЦ РАН, 2012. - С. 89-100.

132. Гаргопа Ю.М. Климатические изменения экосистем южных морей в условиях антропогенных воздействий // Современные рыбохозяйственные и экологические проблемы Азово-Черноморского 
региона: Матер. VII Междунар. конф. (Керчь, 20-23 июля 2012 г.). Керчь: Изд. ЮГНИРО, 2012. - Т. 1. - С. 219-225.

133. Гаргопа Ю.М. Крупномасштабные изменения гидрометеорологических условий формирования рыбопродуктивности южных морей // Комплексные исследования больших морских экосистем России. - Апатиты: Изд-во КНЦ РАН, 2011. - С. 372-389.

134. Гаргопа Ю.М. Азовское море в условиях изменений климатообразующих процессов и антропогенных воздействий // Экосистемные исследования среды и биоты Азовского бассейна. Ростов н/Д.: Изд-во ЮНЦ РАН, 2012. - С. 21-40.

135. Гаргопа Ю.М., Филатова Т.Б. Влияние климатообразующих процессов на биогенные вещества Азовского моря // Изв. вузов. Сев.Кавк. регион. Естест. науки. - 2013. - № 4. - С. 66-69.

136. Гидробиологические индикаторы циклических изменений климата Западной Арктики в XX-XXI вв. / Г.Г. Матишов, Д.В. Моисеев, О.С. Любина, А.П. Жичкин, С.Л. Дюенюк, П.Р. Макаревич, Е.А. Фролова // Вестн. Южного науч. центра РАН. - 2011. - Т. 7, № 2. - С. 54-68.

137. Гидрологический режим губы Дальнезеленецкая / Г.В. Ильин, Д.В. Моисеев, М.С. Громов, Д.В. Широколобов, А.А. Дерябин // Арктическое морское природопользование в XXI веке - современный баланс научных традиций и инноваций (к 80-летию ММБИ КНЦ РАН): Тез. докл. Междунар. науч. конф. (г. Мурманск, 1-3 апреля 2015 г.). Апатиты: Изд-во КНЦ РАН, 2015. - С. 88-90.

138. Громов М.С., Моисеев Д.В., Широколобов Д.В. Гидрометеорологические условия в губе Зеленецкая Баренцева моря летом 2010 г. // Глобальные климатические процессы и их влияние на экосистемы арктических и субарктических регионов: Тез. докл. Междунар. науч. конф. (г. Мурманск, 9-11 ноября 2011 г.). - Апатиты: Изд-во КНЦ PAH, 2011. - C. 25-26.

139. Дженюк С.Л. К оценкам климатических рисков на акваториях и побережьях Баренцева и Белого морей // Региональные эффекты глобальных климатических изменений в XXI веке (причины, последствия, прогнозы): Матер. Междунар. науч. конф. (г. Воронеж, 26-27 июня 2012 г.). - Воронеж: Научная книга, 2012. - С. 480-482.

140. Дженюк С.Л. К оценке океанологической изученности Баренцева и Белого морей // Вестн. Мурм. гос. техн. ун-та. - 2012. Т. 15, № 4. - С. 739-748.

141. Дженюк С.Л. Климатообразующие факторы и климатические особенности Земли Франца-Иосифа // Тр. Кольского науч. центра РАН. 2014. - Т. 4(23). Сер. Океанология. - Вып. 2. - С. 61-69. 
142. Жичкин А.П. Изменчивость климатических условий и география рыболовства в Баренцевом море // Комплексные исследования больших морских экосистем России. - Апатиты: Изд-во КНЦ РАН, 2011. C. $177-202$.

143. Жичкин А.П. Климатические колебания ледовых условий в разных районах Баренцева моря // Метеорология и гидрология. 2012. - № 9. - С. 69-79.

144. Жичкин А.П. Особенности климатических колебаний и рыбный промысел в высокоширотных районах Баренцева моря // Учен. зап. Рос. гос. гидромет. ун-та. - 2013. - № 30. - С. 108-115.

145. Жичкин А.П. Ледовые условия в районе архипелага Земля Франца-Иосифа // Тр. Кольского науч. центра РАН. - 2014. - Т. 4(23). Сер. Океанология. - Вып. 2. - С. 82-89.

146. Жичкин А.П. Воздействие природных и антропогенных факторов на состояние промысловой ихтиофауны и промышленное рыболовство в Баренцевом море // Арктическое морское природопользование в XXI веке - современный баланс научных традиций и инноваций (к 80-летию ММБИ КНЦ РАН): Тез. докл. Междунар. науч. конф. (г. Мурманск, 1-3 апреля 2015 г.). - Апатиты: Изд-во КНЦ РАН, 2015. - С. 68-70.

147. Жичкин А.П. Климатические колебания ледовитости морей западного сектора российской Арктики и их влияние на морехозяйственную деятельность // Северный морской путь: развитие арктических коммуникаций в глобальной экономике «Арктика-2015»: Матер. VI Всерос. мор. науч.-практ. конф., Мурманск, 13-14 мая 2015 г. - Мурманск: Изд-во Мурм. гос. техн. ун-та, 2015. - С. 153-155.

148. Жичкин А.П. Особенности межгодовых и сезонных колебаний аномалий ледовитости Баренцева моря // Метеорология и гидрология. 2015. - № 5. - С. 52- 62 .

149. Жичкин А.П. Динамика межгодовых и сезонных аномалий ледовитости Баренцева и Карского морей // Вестн. Кольского науч. центра РАН. - 2015. - № 1(20). - С. 55-64.

150. Инжебейкин Ю.И., Матишов Д.Г. Субинерционные и сезонные процессы в формировании гидрологических полей на северовосточном побережье Черного моря // Экологическая безопасность приморских регионов (порты, берегозащита, рекреация, марикультура): Матер. Междунар. науч. конф., посвященной 150-летию Н.М. Книповича (Ростов-на-Дону, 5-8 июня 2012 г.). - Ростов н/Д.: Изд-во ЮНЦ РАН, 2012. - C. 105-108.

151. Иикулова Т.Г. Гидрохимические исследования в губе Чупа Кандалакшского залива Белого моря [Электронный ресурс] // Биологические ресурсы Белого моря и внутренних водоемов 
европейского Севера: Тез. докл. XXIX Междунар. конф. (27-29 марта 2013 г., г. Мурманск). - Мурманск: Изд-во ПИНРО, 2013. Электрон. дан. (4 Мб.). - 1 электрон. опт. диск (CD-ROM). - Систем. требования: Windows XP и выше; Word; CD-дисковод; мышь. - (CD192).

152. Климат морей Западной Арктики в начале XXI века / Г.Г. Матишов, С.Л. Дженюк, А.П. Жичкин, Д.В. Моисеев // Изв. РАН. Сер. Геогр. - 2011. - № 3. - С. 17-32.

153. Количество и распределение сестона в Белом море / В.Я. Бергер, М.В. Герасимова, М.В. Митяев, В.В. Смирнов // Проблемы изучения, рационального использования и охраны природных ресурсов Белого моря: Матер. XII Междунар. конф. с элементами школы для молодых ученых и аспирантов (Петрозаводск, 30 сентября-4 октября 2013 г.). - Петрозаводск: Изд-во КарНЦ РАН, 2013. - С. 36-39.

154. Корнеева Г.А., Бардан С.И., Гордеева Е.Л. Использование гидролитических ферментов в процессах самоочищения природных вод Русской Арктики (архипелаг Земля Франца-Иосифа) // Химическая технология: Тез. докл. Междунар. конф. (18-23 марта 2012 г., г. Москва). - М.: ГЕОС, 2012. - С. 264-267.

155. Ледовый режим Азвского моря и климат в начале XXI века / Г.Г. Матишов, А.Л. Чикин, Л.В. Дашкевич, В.В. Кульгин, Л.Г. Чикина // Докл. РАН. - 2014. - Т. 457, № 5. - С. 603-607.

156. Матишов Г.Г. Исследования климатических изменений морских экосистем - приоритетное направление полярной океанологии // Глобальные климатические процессы и их влияние на экосистемы арктических и субарктических регионов: Тез. докл. Междунар. науч. конф. (г. Мурманск, 9-11 ноября 2011 г.). - Апатиты: Изд-во КНЦ PAH, 2011. - C. 5-7.

157. Матишов Г.Г. Случаи экстремальной адвекции соленых вод в дельту Дона и льда в Керченский пролив // Докл. РАН. - 2015. Т. 465, № 1. - С. 99-103.

158. Матишов Г.Г. Климат и океанографические исследования северных и южных морей // Вестн. Кольского науч. центра РАН. 2015. - № 2(21). - С. 11-19.

159. Матишов Г.Г., Бердников С.В. Экстремальное затопление дельты Дона весной 2013 г. // Изв. РАН. Сер. Геогр. - 2015. - № 1. C. 111-118.

160. Матишов Г.Г., Жичкин А.П. Влияние климатических флуктуаций на промысловую ихтиофауну экосистемы Баренцева моря // Вестн. Южного науч. центра РАН. - 2013. - Т. 9, № 1. - С. 61-70. 
161. Матишов Г.Г., Инжебейкин Ю.И. Субинерционные движения на северо-восточном шельфе Черного моря // Докл. РАН. 2012. - Т. 446, № 6. - С. 686-689.

162. Матишов Г.Г., Клещенков А.В. Кубанский паводковый кризис. Климат, геоморфология, прогноз. Крымск, июль 2012 г. Ростов н/Д.: Изд-во ЮНЦ РАН, 2012. - 116 с.

163. Матишов Г.Г., Моисеев Д.В. Исследования термохалинных характеристик вод в районе Земли Франца-Иосифа // Тр. Кольского науч. центра РАН. - 2014. Т. 4(23). - Сер. Океанология. - Вып. 2. C. $69-82$.

164. Матишов Г.Г., Гасанова А.Ш., Ковалева Г.В. Влияние изменений гидролого-гидрохимического режима Каспийского моря на развитие микроводорослей в прибрежной зоне // Докл. РАН. - 2011. T. 437, № 3. - С. 404-408.

165. Матишов Г.Г., Матишов Д.Г., Шевердяев И.В. Обстоятельства затопления Олимпийской деревни в Адлере: Отчет о результатах экспедиции по маршруту Туапсе-Сухуми (01-08.08.2015 г.). - Ростов н/Д.: Изд-во ЮНЦ РАН, 2015. - 64 с.

166. Матишов Г.Г., Яиикая Н.А., Бердников С.В. Особенности внутривекового режима солености Каспийского моря // Докл. РАН. 2012. - Т. 444, № 5. - С. 549-553.

167. Матишов Д.Г., Гаргопа Ю.М., Елисеева О.И. Современный гидрохимический режим водоемов и водотоков Кумо-Манычской впадины в условиях изменений климата и антропогенных воздействий // Современное состояние и технологии мониторинга аридных и семиаридных экосистем юга России. - Ростов н/Д.: Изд-во ЮНЦ РАН, 2010. - C. 102-113.

168. Мишина Н.Н. Особенности распределения гидрохимических параметров во внутренней акватории о. Западный Шпицберген летом 2008 г. // Материалы XXIX конференции молодых ученых Мурманского морского биологического института, посвященной 140 -летию со дня рождения Г.А. Клюге, «Морские исследования экосистем европейской Арктики» (г. Мурманск, май 2011 г.). - Мурманск: Изд. ММБИ КНЦ PAH, 2011. - C. 153-155.

169. Моисеев Д.В. Использование отрывных зондирующих систем с борта судов ледового класса на акватории Севморпути [Электронный peсурс] // Наука и образование - 2014: Матер. Междунар. науч.-техн. конф., Мурманск, 24-28 марта 2014 г. - Электрон. текст. дан. Мурманск: Изд-во Мурм. гос. техн. ун-та, 2014. - С. 246-250. 1 электрон. опт. диск (CD-ROM). - Систем. требования: PC не ниже класса Pentium II; 128 Mb РАM; свободное место на HDD 100 Mb; 
Adobe Acrobat Reader; дисковод CD-ROM 2-х и выше. - Загл. с экрана. Электрон. текст подг. ФГБОУ ВПО «МГТУ». - № гос. регистрации 0321401155.

170. Моисеев Д.В., Бобров К.А. Океанографические исследования в заливе Грён-фьорд // Арктическое морское природопользование в XXI веке - современный баланс научных традиций и инноваций (к 80-летию ММБИ КНЦ РАН): Тез. докл. Междунар. науч. конф. (г. Мурманск, 1-3 апреля 2015 г.). - Апатиты: Изд-во КНЦ РАН, 2015. С. 168-169.

171. Моисеев Д.В., Громов М.С. Гидрометеорологические условия в губе Долгой Баренцева моря // Вестн. Кольского науч. центра РАН. 2015. - № 1(20). - С. 65-77.

172. Моисеев Д.В., Духно Г.Н. Верификация температуры поверхности моря по данным дистанционного зондирования Земли и in situ для Карского моря // Арктическое морское природопользование в XXI веке - современный баланс научных традиций и инноваций (к 80-летию ММБИ КНЦ РАН): Тез. докл. Междунар. науч. конф. (г. Мурманск, 1-3 апреля 2015 г.). - Апатиты: Изд-во КНЦ РАН, 2015. C. 169-170.

173. Морские испытания многоканальной измерительнотехнологической платформы / Г.В. Смирнов, Г.Г. Матишов, А.Л. Оленин, Е.А. Аистов, К.С. Григоренко, О.В. Степаньян // Вестн. Южного науч. центра РАН. - 2014. - Т. 10, № 3. - С. 54-60.

174. Морские экспедиционные исследования на научноисследовательских судах «Денеб» и «Профессор Панов» в 2013 г. / Г.Г. Матишов, О.В. Степаньян, К.С. Григоренко, В.М. Харьковский, В.В. Поважный, В.В. Польшин, В.Г. Сойер // Океанология. - 2015. T. 55, № 5. - C. 861-865.

175. Необходимое условие существования квазипериодических нелинейных внутренних волн в непрерывно стратифицированном море переменной глубины / С.М. Хартиев, К.С. Григоренко, А.А. Соловьева, Д.Г. Матишов // Вестн. Южного науч. центра РАН. - 2012. - Т. 8, № $1 .-$ C. 23-27.

176. Омельчук P.B. Биогенные элементы в ноябре на разрезе «Кольский меридиан» // Материалы XXXI конференции молодых ученых Мурманского морского биологического института, посвященной 135летию со дня рождения К.М. Дерюгина, «Океанография и биология арктических морей» (г. Мурманск, май 2013). - Мурманск: Изд. ММБИ КНЦ РАН, 2013. - С. 147-149.

177. О природы крупных гидрометеорологических аномалий в арктических и южных морях России / Г.Г. Матишов, С.Л. Дженюк, Д.В. Моисеев, А.П. Жичкин // Изв. РАН. Сер. Геогр. - 2014. - № 1. C. 36-46. 
178. Особенности гидролого-гидрохимического режима Азовского и Черного морей в 2013 г. / Г.Г. Матишов, О.В. Степаньян, К.С. Григоренко, В.М. Харьковский, В.В. Поважный, В.Г. Сойер // Вестн. Южного науч. центра. - 2015. - Т. 11, № 2. - С. 36-44.

179. Павлова Л.Г., Иикулова Т.Г. Исследование параметров гидрохимического комплекса в губе Териберская // Арктическое морское природопользование в XXI веке - современный баланс научных традиций и инноваций (к 80-летию ММБИ КНЦ РАН): Тез. докл. Междунар. науч. конф. (г. Мурманск, 1-3 апреля 2015 г.). Апатиты: Изд-во КНЦ РАН, 2015. - С. 185-186.

180. Пастухов И.А. Гидрохимические показатели разреза «Кольский меридиан» в ноябре 2013 года // Эколого-эволюционные исследования морских организмов и экосистем: Матер. XIV Междунар. науч. конф. студентов и аспирантов «Проблемы Арктического региона» (г. Мурманск, май 2014 г.). Т. І. Форум молодых ученых, посвященный 110 -летию со дня рождения Ю.И. Полянского (XXXII конференция молодых ученых ММБИ). - Мурманск: Изд. ММБИ КНЦ РАН, 2014. C. $136-141$.

181. Пастухов И.А. Уровень активности щелочной фосфатазы в море Лаптевых летом 2014 г. // Арктическое морское природопользование в XXI веке - современный баланс научных традиций и инноваций (к 80-летию ММБИ КНЦ РАН): Тез. докл. Междунар. науч. конф. (г. Мурманск, 1-3 апреля 2015 г.). - Апатиты: Изд-во КНЦ РАН, 2015. - C. 190-191.

182. Связь между концентрацией различных форм фосфора и хлорофилла $a$ в Таганрогском заливе Азовского моря в 2008-2010 гг. / В.В. Поважный, С.В. Бердников, Е.П. Пономаренко, А.В. Шишкина // Экосистемные исследования среды и биоты Азовского бассейна. Ростов н/Д.: Изд-во ЮНЦ РАН, 2012. - С. 116-124.

183. Современная многолетняя изменчивость термохалинного состояния вод Баренцева моря / В.В. Денисов, Г.В. Ильин, Д.В. Моисеев, А.П. Жичкин // Океанография и морской лед. - М.; СПб.: Paulsen, 2011. C. 227-238.

184. Современные климатические тенденции в Баренцевом море / Г.Г. Матишов, В.В. Денисов, А.П. Жичкин, Д.В. Моисеев, М.С. Громов // Докл. РАН. - 2011. - Т. 441, № 3. - С. 395-398.

185. Современные океанологические процессы в западноарктических и южных морях России / Г.Г. Матишов, С.Л. Дженюк, Д.В. Моисеев, А.П. Жичкин // Морские экосистемы и сообщества в условиях современных климатических изменений. - СПб.: Реноме, 2014. - С. 13-31. 
186. Современный гидролого-гидрохимический режим Цимлянского водохранилища / Ю.М. Гаргопа, В.Д. Панов, П.М. Лурье, Е.Г. Алёшина, Н.В. Алёшина, Т.Б. Филатова // Цимлянское водохранилище: состояние водных и прибрежных экосистем, проблемы и пути решения. - Ростов н/Д.: Изд-во ЮНЦ РАН, 2011. - С. 14-29.

187. Учет вековой динамики климата Баренцева моря при планировании морской деятельности / Г.Г. Матишов, С.Л. Дженюк, В.В. Денисов, А.П. Жичкин, Д.В. Моисеев // Тр. Кольского науч. центра РАН. - 2013. - Т. 1(14). - Сер. Океанология. - Вып. 1. - С. 56-71.

188. Экстремальное наводнение в дельте Дона (23-24 марта 2013 г.) и факторы, его определяющие / Г.Г. Матишов, А.Л. Чикин, С.В. Бердников, И.В. Шевердяев // Докл. РАН. - 2014. - Т. 455, № 3. C. 342-345.

189. Экстремальное затопление дельты Дона весной 2013 г: хронология, условия формирования и последствия / Г.Г. Матишов, А.Л. Чикин, С.В. Бердников, И.В. Шевердяев, А.В. Клещенков, E.Э. Кириллова // Вестн. Южного науч. центра РАН. - 2014. - Т. 10, № 1. - C. 17-24.

190. Яицккая H.A. Термохалинный режим Каспийского моря при изменении уровня: Автореф. дис. ... канд. геогр. наук (25.00.28. океанология). - Мурманск, 2012. - 28 с.

191. Climate and oceanographic processes in the Barents Sea / G.G. Matishov, S.L. Dzhenyuk, V.V. Denisov, A.P. Zhichkin, D.V. Moiseev // Berichte zur Polarforschung. - 2012. - № 640. - P. 63-73.

192. Climatic anomalies in the beginning of 2012 in the area of Arctic and European seas [Электронный ресурс]/G. Matishov, S. Dzhenyuk, D. Moiseev, A. Zhichkin // Arctic Frontiers 2015. Climate and Energy: Science conference (Tromsø, Norway, 18-23 January 2015). - URL: http:// arcticfrontiers.conference-services.net/reports/template/onetextabstract. $\mathrm{xml}$ ?xsl= template/onetextabstract.xsl\&conferenceID $=4282 \&$ abstractID $=866321$

193. From fresh to marine waters: characterization and fate of dissolved organic matter in the Lena River delta region, Siberia / $R$. GonçalvesAraujo, C.A. Stedmon, B. Heim, I. Dubinenkov, A. Kraberg, D. Moiseev, A. Bracher // Frontiers Mar. Sci. - 2015. - Vol. 2, article 108. - Doi: 10.3389/fmars.2015.00108. - URL: http://journal.frontiersin.org/article/10. 3389/fmars.2015.00108/full?utm_source=Email_to_authors_\&utm medium= Email\&utm_content $=\mathrm{T} 1 \_11.5 \mathrm{e} 1 \_$author\&utm_campaign $=$Email pub̄lication\& field $=\&$ journalName $=$ Frontiers_in_Marine_Science\&id $=170808$

194. Marine investigations on the research vessels Deneb and Professor Panov during Expeditions in 2013 / G.G. Matishov, O.V. Stepan'yan, K.S. Grigorenko, V.M. Khar'kovskii, V.V. Povazhnyi, V.V. Pol'shin, V.G. Soier // Oceanology. - 2015. - Vol. 55, № 5. - P. 780-784. 
195. Pronounced anomalies of air, water, ice conditions in the Barents and Kara seas, and the Sea of Azov / G.G. Matishov, S.L. Dzhenyuk, D.V. Moiseev, A.P. Zhichkin // Oceanologia. - 2014. - № 56(3). P. 445-460.

196. Recent climatic tendencies in the Barents Sea / G.G. Matishov, V.V. Denisov, A.P. Zhichkin, D.V. Moiseev, M.S. Gromov // Doklady Earth Sci. - 2011. - Vol. 441, № 1. - P. 1602-1606.

197. Trends in hydrological and ice condition sin the Large Marine Ecosystems of the Russian Arctic during periods of climate change / G.G. Matishov, S.L. Dzhenyuk, D.V. Moiseev, A.P. Zhichkin // Environmental Development. - 2015. - P. 1-13. - URL: http://dx.doi.org/10.1016/j.envdev. 2015.10.001i

198. Zhichkin A.P. Peculiarities of international and seasonal variations of the Barents Sea ice coverage anomales // Russian Meteorology and Hydrology. - 2015. - Vol. 40, № 5. - P. 319-326.

\section{МОДЕЛИРОВАНИЕ. ИНФОРМАЦИОННЫЕ ТЕХНОЛОГИИ}

199. Ващенко П.С., Калинка О.П. Разработка базы данных для интерактивной карты чувствительности берегов Кольского залива к разливам нефти // Материалы XXIX конференции молодых ученыX Мурманского морского биологического института, посвященной 140летию со дня рождения Г.А. Клюге, «Морские исследования экосистем европейской Арктики» (г. Мурманск, май 2011 г.). - Мурманск: Изд. ММБИ КНЦ РАН, 2011. - С. 25-29.

200. Дворецкий А.Г. Модель роста молоди камчатского краба в Баренцевом море // Тр. Зоол. ин-та РАН. - 2011. - Т. 315, № 1. C. $75-84$.

201. Иванов C.A. Новые подходы к обработке гидрологических данных на стандартных разрезах Баренцева моря // Вестн. Южного науч. центра РАН. - 2011. - Т. 7, № 4. - С. 46-54.

202. Иванов C.A. Оценка качества информации базы океанографических данных на стандартных разрезах Баренцева моря // Материалы XXIX конференции молодых ученых Мурманского морского биологического института, посвященной 140 -летию со дня рождения Г.А. Клюге, «Морские исследования экосистем европейской Арктики» (г. Мурманск, май 2011 г.). - Мурманск: Изд. ММБИ КНЦ РАН, 2011. - С. 89-93.

203. Иванов C.A. Оценка соответствия информации в базе океанографических данных на стандартных разрезах Баренцева моря по достоверным массивам // Изучение и освоение морских и наземных экосистем в условиях арктического и аридного климата: Матер. 
Междунар. науч. конф. (6-11 июня 2011 г., Ростов-на-Дону). - Ростов н/Д.: Изд-во ЮНЦ РАН, 2011. - С. 400-404.

204. Информационное обеспечение исследований климатической динамики морских экосистем / Г.Г. Матишов, С.В. Бердников, А.П. Жичкин, В.В. Кульгин, Н.А. Яичкая, С.В. Кумпан, И.А. Третьякова, И.В. Шевердяев, А.Е. Цыганкова, С.Л. Дюенюк, С. Левитус, И.В. Смоляр // Морские экосистемы и сообщества в условиях современных климатических изменений. - СПб.: Реноме, 2014. - С. 31-49.

205. Макаревич П.Р., Гайденок Н.Д., Огнетов Г.Н. Об одном из вариантов моделирования динамики беломорской популяции гренландского тюленя (Phoca groenlandica) // Морские млекопитающие Голарктики 2012: Сб. науч. тр. по матер. VII Междунар. конф. (г. Суздаль, 24-28 сентября 2012 г.). - М.: РОО «Совет по морским млекопитающим», 2012. - T. 2. - C. 406-409.

206. Матишов Г.Г., Чикин А.Л. Исследования ветровых течений в Керченском проливе с помощью математического моделирования // Вестн. Южного науч. центра РАН. - 2012. - Т. 8, № 2. - С. 27-32.

207. Матишов Г.Г., Чикин А.Л. Один из подходов к моделированию ветровых течений в Керченском проливе // Докл. РАН. - 2012. - Т. 445, № 3. - C. 342-345.

208. Матишов Г.Г., Гаргопа Ю.М., Чикин А.Л. Моделирование ледостава в Азовском море с учетом климатического тренда в начале XXI века // Докл. РАН. - 2012. - Т. 445, № 5. - С. 590-593.

209. Матишов Г.Г., Моисеев Д.В., Духно Г.Н. Создание тематических разделов «Экология и природопользование», «Морская биология», «Загрязнение» электронного морского атласа «ЕСИМО» по Балтийскому, Белому, Баренцеву морям // V Международная конференция «Геоинформационные технологии и космический мониторинг», Всероссийское совещание консорциума «Университетские геопорталы УНИГЕО» (2-6 сентября 2012 г.). - Ростов н/Д.: Изд-во Южного фед. ун-та, 2012. - С. 17-20.

210. Матишов Г.Г., Моисеев Д.В., Духно Г.Н. Создание тематического раздела «Загрязнение морских вод» электронного морского атласа «ЕСИМО» по арктическим морям Российской Федерации // Экология. Экономика. Информатика (8-13 сентября 2013 г.): В 2-х т. T. 2. Геоинформационные науки и экологическое развитие: новые подходы, методы, технологии. Геоинформационные технологии и космический мониторинг. - Ростов н/Д.: Изд-во Южного фед. ун-та, 2013. - C. 182-184.

211. Моисеев Д.В., Духно Г.Н. Геоинформационный анализ передвижений арктических ластоногих со спутниковыми метками // Дистанционные методы исследования в зоологии: Матер. науч. конф. 
(28-29 ноября 2011 г., г. Москва, ИПЭЭ РАН). М.: Тов-во науч. изд. KMK, 2011. - C. 54.

212. Моисеев Д.В., Духно Г.Н. Создание тематических разделов для электронного морского атласа «ЕСИМО» по морям Российской Федерации // Современные проблемы экологии и природопользования: Матер. регион. науч.-практ. конф., посвященной 15-летию со дня основания кафедры биоэкологии, Мурманск, 27-28 февраля 2014 г. Мурманск: Изд-во Мурм. гос. техн. ун-та, 2014. - С. 195-201.

213. Моисеев Д.В., Духно Г.Н. Обработка и анализ передвижений арктических ластоногих с датчиками спутниковой телеметрии // Экологическая стратегия развития прибрежных регионов: география, окружающая среда, население. Медико-экологические и социальноэкономические проблемы прибрежных регионов: Матер. Всерос. науч. конф. (г. Ростов-на-Дону, 15-18 декабря 2015 г.). - Ростов н/Д.: Изд-во ЮНЦ РАН, 2015. - С. 151-157.

214. Моисеев Д.В., Духно Г.Н., Дерябин А.А. Изучение маршрутов передвижения гренландских тюленей со спутниковыми метками // Морские животные на службе человеку: Матер. науч.-практ. семинара (4 октября 2010 г., Североморск). - Ростов н/Д.: Изд-во ЮНЦ РАН, 2011. - С. 53-56.

215. Океанографическая база данных Азовского моря за 100 лет наблюдений / Г.Г. Матишов, С.В. Бердников, В.В. Кульлгин, А.В. Шишкина // Азовское море, Керченский пролив и предприливные зоны в Черном море: проблемы управления прибрежными территориями для обеспечения экологической безопасности рационального природопользования. Ростов н/Д.: Изд-во ЮНЦ РАН, 2012. - С. 72-81.

216. О проекте «Разработка компьютерной системы оперативного прогнозирования опасных природных явлений в бассейне, береговой зоне и акватории Азовского моря» / Г.Г. Матишов, С.В. Бердников, В.В. Кульглин, А.Л. Чикин, О.Е. Архипова, Н.А. Яиикая, Н.В. Лихтанская, Л.В. Дашкевич, В.В. Сорокина, В.В. Сапрыгин, И.А. Третьякова, И.В. Шевердяев, В.М. Кушнир, В.В. Фомин, Е.Л. Шержуков // Экология. Экономика. Информатика (7-12 сентября 2014 г.): В 2-х т. Т. 1. Системный анализ и моделирование экономических и экологических систем. - Ростов н/Д.: Изд-во Южного фед. ун-та, 2014. С. 56-62.

217. Разработка гидробиологических и экологических разделов электронного атласа «ЕСИМО» по морям Российской Федерации [Электронный ресурс] / Г.Г. Матишов, Д.В. Моисеев, Г.Н. Духно, С.В. Бердников, Ю.М. Льчагина, Н.А. Яицкая // ЕСИМО'2012 конференция для разработчиков и специалистов исследовательских и проектных организаций и представителей федеральных органов 
исполнительной власти РФ (г. Обнинск, 24-28 сентября 2012 г.). 2012. - C. 1-4. - URL: http://conference.oceaninfo.ru/files new/138201207-24-23-20-34.doc

218. Разработка интегрированной математической модели большой морской экосистемы Баренцева и Белого морей для оценки природных рисков и эффективного использования биологических ресурсов / С.В. Бердников, А.Е. Цыганкова, И.В. Шевердяев, В.В. Кулыгин, В.В. Сорокина, О.Е. Архипова, Ю.М. Льчагина, Н.А. Яицкая // Экология. Экономика. Информатика (8-13 сентября 2013 г.): В 2-х т. T. 2. Геоинформационные науки и экологическое развитие: новые подходы, методы, технологии. Геоинформационные технологии и космический мониторинг. - Ростов н/Д.: Изд-во Южного фед. ун-та, 2013. - C. 57-63.

219. Разработка атласа климатических изменений в больших морских экосистемах северных и южных морей России (1878-2013 гг.) / Г.Г. Матитов, С.В. Бердников, А.П. Жичкин, С.Л. Дюенюк, В.В. Кульгиин, Н.А. Яичкая, С.В. Кумпан, И.А. Третьякова, И.В. Шевердяев, А.Е. Цыганкова, С. Левитус, И. Смоляр // Экология. Экономика. Информатика (8-13 сентября 2013 г.): В 2-х т. Т. 2. Геоинформационные науки и экологическое развитие: новые подходы, методы, технологии. Геоинформационные технологии и космический мониторинг. - Ростов н/Д.: Изд-во Южного фед. ун-та, 2013. - С. 86-30.

220. Совместные подходы ММБИ, ЮНЦ и Лаборатории климата океана HOAA (США) к организации океанографических и гидробиологических баз данных арктических и южных морей России / Г.Г. Матишов, Д.В. Моисеев, С.В. Бердников, В.В. Кульгин, Н.А. Яиикая, А.В. Шишкина // Тр. Кольского науч. центра РАН. - 2013. Т. 1(14). - Сер. Океанология. - Вып. 1. - С. 135-152.

221. Создание тематических разделов «Экология и природопользование», «Морская биология», «Гидродинамика» и «Загрязнение» электронного морского атласа «ЕСИМО» по морям Российской Федерации / С.В. Бердников, Ю.М. Лычагина, Н.А. Яицкая, Д.В. Моисеев, М.С. Громов, Г.Н. Духно, А.А. Дерябин // IV конференция «Геоинформационные технологии и космический мониторинг» (пос. Дюрсо, 6-8 сентября 2011 г.). - Ростов н/Д.: ЦВВР, 2011. - С. 101-102.

222. Усягина И.С., Бердников С.В. Моделирование динамики ${ }^{137} \mathrm{Cs}$ в воде и донных отложениях Баренцева и Белого морей в период 1960-2010 гг. [Электронный ресурс] // Биологические ресурсы Белого моря и внутренних водоемов европейского Севера: Тез. докл. XXIX Междунар. конф., 27-29 марта 2013 г., г. Мурманск, Россия. Мурманск: Изд-во ПИНРО, 2013. Электрон. дан. (4 Мб). - 1 электрон. 
опт. диск (CD-ROM). - Систем. требования: Windows XP и выше; Word; CD-дисковод; мышь. - (CD192).

223. Цыганкова A.Е., Бердников С.В. Ледовитость Белого моря в период 1940-2010 гг. по результатам математического моделирования и спутникового мониторинга [Электронный ресурс] // Биологические ресурсы Белого моря и внутренних водоемов европейского Севера: Тез. докл. XXIX Междунар. конф., 27-29 марта 2013 г., г. Мурманск, Россия. - Мурманск: Изд-во ПИНРО, 2013. Электрон. дан. (4 Мб). 1 электрон. опт. диск (CD-ROM). - Систем. требования: Windows XP и выше; Word; CD-дисковод; мышь. - (CD192).

224. Arctic seas phytoplankton database 1921-2011 / P.R. Makarevich, D.V. Moiseev, E.I. Druzhkova, A.A. Oleinik // Celebrating 50 years of science at Helgoland Roads: Abstr. book (September, 18-20, 2012, Helgoland, Germany). - Helgoland, 2012. - P. 24.

225. Assessment of seasonal and decadal signals in the in situ Atlantic plankton data / J. Bruun, A. Rees, J. Stephens, S. Thomalla, R. Philibert, H. Waldron, P. Somerfield, E. Jeansson, R. Bellerby, D. Moiseev// ICES. Annual Science Conference: Abstr. book (Bergen, Norway, 17-21 September 2012). - Copenhagen: ICES, 2012. - P. 5. - URL: http://www.ices.dk/iceswork/asc/2012/themesessions/themesessions.asp

226. Atlantic province-based comparison of plankton dominance from satellite, model and data [Электронный pecypc] / J. Bruun, I. Allen, M. Vichi, P. Somerfield, A. Samuelsen, M.-F. Racault, H. Waldron, P. Monteiro, W. McKiver, R. Bellerby, S. Thomalla, K. Lygre, D. Moiseev, J. Johannessen, R. Brewin, M. Butenschön, E. Jeansson // The 2013 European Space Agency Living Planet Symposium: Abstr. (Edinburgh, 09-13 September 2013). Ocean Colour 3. - URL: http://www.livingplanet2013.org/abstracts/850766.htm

227. Moiseev D.V., Duhno G.N., Fedorkova Yu.V. Verification of remote sensing basic products with in situ data for the Kara Sea // Geoinformation sciences and environmental development: New approaches, methods, technologies: collection of articles of the II international conference (May 5-9, 2014, Limassol, Cyprus). - Rostov-on-Don: Publ. house SSC RAS, 2014. - P. 137-140.

228. Moiseev D.V., Kulygin V.V., Berdnikov S.V. Joint MMBI, SSC RAS and NODC NOAA approach to oceanographic and hydro-biological database organisation for the Arctic and Southern seas of Russia // Berichte zur Polarforschung. - 2012. - № 640. - P. 137-151.

229. Oceanic biogeochemical characteristic maps identified with holistic use of satellite, model and data / J. Bruun, I. Allen, M. Vichi, P. Somerfield, A. Samuelsen, M.-F. Racault, H. Waldron, P. Monteiro, W. McKiver, R. Bellerby, S. Thomalla, K. Lygre, D. Moiseev, J. Johannessen, R. Brewin, 
M. Butenschön, E. Jeansson, A. Vines, J. Heard // EGU General Assembly 2014. Geophysical Res.: Abstr. - 2014. - Vol. 16. - URL: EGU2014-15766

230. Zhichkin A. Electronic database of MMBI on cod fishery geography in the Barents Sea ecosystem // Arctic Frontiers 2013. Geopolitics and marine production in a cangini Arctic: Abstr. book (Tromsø, Norway, 20-25 January 2013). - Tromsø, 2013. - P. 152. - URL: www.arcticfrontiers.com

\section{ГИДРОБИОЛОгИЯ}

\section{Микробиологические сообщества}

231. Бактерии и вирусы эстуарных вод Карского моря / М.А. Павлова, Т.И. Широколобова, М.П. Венгер, В.В. Водопьянова // Арктическое морское природопользование в XXI веке - современный баланс научных традиций и инноваций (к 80-летию ММБИ КНЦ РАН): Тез. докл. Междунар. науч. конф. (г. Мурманск, 1-3 апреля 2015 г.). Апатиты: Изд-во КНЦ РӒ, 2015. - С. 187-188.

232. Бардан С.И. Закономерности формирования пространственной структуры бактериоценозов в зимнем планктоне Печорского моря // Изв. РАН. Сер. геогр. - 2014. - № 6. - С. 62-74.

233. Бардан С.И. Метод оценки продукционного потенциала морских бактериоценозов для зимних условий морей Западной Арктики // Экологическая безопасность приморских регионов (порты, берегозащита, рекреация, марикультура): Матер. Междунар. науч. конф., посвященной 150-летию Н.М. Книповича (Ростов-на-Дону, 5-8 июня 2012 г.). - Ростов н/Д.: Изд-во ЮНЦ РАН, 2012. - С. 43-47.

234. Бардан С.И. Размерная структура и морфологический состав зимнего бактериопланктона Печорского моря и условия формирования // Микробиология. - 2013. - Т. 82, № 6. - С. 741-752.

235. Бардан С.И., Сербов Н.Г. Условия формирования и состав доминирующих групп в бактериальных ценозах зимнего планктона на примере Печорского моря // Український гидромет. журн. - 2014. № 14. - С. 213-226.

236. Бардан С.И., Сербов Н.Г. Фракталы в биогеографических закономерностях, определяющих состав бактериоценозов зимнего планктона на примере Печорского моря // Вісник Одеського державного екологічного університету. - 2014. - Вип. 17. - С. 141-156.

237. Венгер М.П. Сообщества бактериопланктона в водах архипелагов Шпицберген и Земля Франца-Иосифа // Материалы XXIX 
конференции молодых ученых Мурманского морского биологического института, посвященной 140 -летию со дня рождения Г.А. Клюге, «Морские исследования экосистем европейской Арктики» (г. Мурманск, май 2011 г.). - Мурманск: Изд. ММБИ КНЦ РАН, 2011. - С. 29-33.

238. Венгер М.П. Бактериопланктон северо-восточной части Баренцева моря // Вестн. Южного науч. центра РАН. - 2011. - Т. 7, № 4. - С. 55-60.

239. Венгер М.П. Новый фактор контроля микропланктонных сообществ арктобореальной зоны // Биоресурсы и аквакультура: Тез. докл. Школы молодых ученых по морской биологии (Мурманск, 28-29 февраля 2012 г.). - Мурманск: Изд-во Мурм. гос. техн. ун-та, 2012. C. $11-14$.

240. Венгер М.П. Микробные сообщества в водах западного побережья архипелага Новая Земля // Материалы XXX юбилейной конференции молодых ученых Мурманского морского биологического института, посвященной 150 -летию со дня рождения Н.М. Книповича, «Проблемы океанографии, биологии и освоения биоресурсов морей российской Арктики» (г. Мурманск, май 2012). - Мурманск: Изд. ММБИ КНЦ РАН, 2012. - С. 31-36.

241. Венгер М.П. Летний бактериопланктон в арктических и субарктических прибрежных экосистемах [Электронный ресурс] // Наука и образование - 2013: Матер. Междунар. науч.-техн. конф., Мурманск, 4-11 марта 2013 г. - Электрон. текст. дан. (220 Мб). Мурманск: Изд-во Мурм. гос. техн. ун-та, 2013. - С. 222-224. - 1 опт. компакт-диск (CD-ROM). Систем. требования: PC не ниже класса Pentium II 128 Mb RAM; свободное место на HDD $130 \mathrm{Mb}$; привод для компакт-дисков CD-ROM 2-х и выше. - Электрон. текст подгот. ФГБОУ ВПО «МГТУ». - № гос. регистрации 0321301202.

242. Венгер М.П. Результаты исследования микропланктонных сообществ в губе Дальнезеленецкой летом 2012 г. // Материалы XXXI конференции молодых ученых Мурманского морского биологического института, посвященной 135-летию со дня рождения К.М. Дерюгина, «Океанография и биология арктических морей» (г. Мурманск, май 2013). - Мурманск: Изд. ММБИ КНЦ РАН, 2013. - С. 38-45.

243. Венгер М.П. Исследование вириопланктона в Баренцевом море в период полярной ночи // Микроорганизмы и вирусы в водных экосистемах: Матер. 4-го Байкальского микробиол. симп. с междунар. участием (Иркутск, ЛИН СО РАН, 7-12 сентября, 2015 г.). - Иркутск: Аспринт, 2015. - С. 260-262.

244. Венгер М.П., Широколобова Т.И. Виро- и бактериопланктон шельфа Баренцева моря // Современные эколого-биологические и 
химические исследования, техника и технология производств: Матер. Междунар. науч.-практ. конф., Мурманск, 7 апреля 2015 г.: В 2-х ч. Мурманск: Изд-во Мурм. гос. техн. ун-та, 2015. - Ч. 1. - С. 199-205.

245. Венгер М.П., Копьлов А.И., Заботкина Е.А. Вириопланктон открытых и прибрежных акваторий Баренцевоморского шельфа // Современные проблемы физиологии, экологии и биотехнологии микроорганизмов: Всерос. симпозиум с междунар. участием (г. Москва, МГУ, 24-27 декабря 2014 г.). - М.: МАКС Пресс, 2014. - С. 51.

246. Венгер М.П., Макаревич П.Р., Водопьянова В.В. Результаты исследований виропланктона Баренцева моря в летний период // Глобальные климатические процессы и их влияние на экосистемы арктических и субарктических регионов: Тез. докл. Междунар. науч. конф. (г. Мурманск, 9-11 ноября 2011 г.). - Апатиты: Изд-во КНЦ РАН, 2011. - C. 16-17.

247. Венгер М.П., Широколобова Т.И., Вдопьянова В.В. Бактериопланктон архипелагов Баренцева моря // Изучение и освоение морских и наземных экосистем в условиях арктического и аридного климата: Матер. Междунар. науч. конф. (6-11 июня 2011 г., Ростов-на-Дону). Ростов н/Д.: Изд-во ЮНЦ РАН, 2011. - С. 246-247.

248. Вирусы в пелагиали Баренцева моря / M.П. Венгер, Т.И. Широколобова, П.Р. Макаревич, В.В. Водопьянова // Докл. РАН. 2012. - T. 446, № 3. - С. 345-349.

249. Компоненты микропланктона арктических и субарктических экосистем Баренцевоморского шельфа / Т.И. Широколобова, М.П. Венгер, П.Р. Макаревич, В.В. Водопьянова // Арктическое морское природопользование в XXI веке - современный баланс научных традиций и инноваций (к 80-летию ММБИ КНЦ РАН): Тез. докл. Междунар. науч. конф. (г. Мурманск, 1-3 апреля 2015 г.). - Апатиты: Изд-во КНЦ РАН, 2015. - С. 256-258.

250. Культивируемые бактерии летнего периода в водах арктической эстуарной зоны / Т.И. Широколобова, М.П. Венгер, М.А. Павлова, Н.Н. Мишина // Изучение и освоение морских и наземных экосистем в условиях арктического и аридного климата: Матер. Междунар. науч. конф. (6-11 июня 2011 г., Ростов-на-Дону). Ростов н/Д.: Изд-во ЮНЦ РАН, 2011. - С. 113-116.

251. Павлова М.A. Структура гетеротрофного бактериопланктона Кольского залива [Электронный ресурс] // Наука и образование - 2012: Матер. Междунар. науч.-техн. конф., Мурманск, 2-6 апреля 2012 г. Мурманск: Изд-во Мурм. гос. техн. ун-та, 2012. - С. 486-490. - URL: http://www.mstu.edu.ru/science/conferences/nio2012/

252. Павлова М.A. Бактериопланктон губ Восточного Мурмана в период активной вегетации кокколитофорид // Материалы XXXI 
конференции молодых ученых Мурманского морского биологического института, посвященной 135 -летию со дня рождения К.М. Дерюгина, «Океанография и биология арктических морей» (г. Мурманск, май 2013). - Мурманск: Изд. ММБИ КНЦ РАН, 2013. - С. 155-162.

253. Павлова М.А. Вириопланктон карскоморских эстуариев // Микроорганизмы и вирусы в водных экосистемах: Матер. 4-го Байкальского микробиологического симпозиума с международным участием (Иркутск, ЛИН СО РАН, 7-12 сентября, 2015 г.) - Иркутск: Аспринт, 2015. - С. 291-292.

254. Павлова М.А., Венгер М.П. Бактерии и вирусы прибрежных экосистем арктических морей в летний вегетационный период микроводорослей // Современные эколого-биологические и химические исследования, техника и технология производств: Матер. Междунар. науч.-практ. конф., Мурманск, 7 апреля 2015 г.: В 2-х ч. - Мурманск: Изд-во Мурм. гос. техн. ун-та, 2015. - Ч. 1. - С. 254-259.

255. Павлова М.A., Водопьянова В.В. Бактериопланктонные сообщества Обско-Тазовской губы // Эколого-эволюционные исследования морских организмов и экосистем: Матер. XIV Междунар. науч. конф. студентов и аспирантов «Проблемы Арктического региона». Т. I. Форум молодых ученых, посвященный 110-летию со дня рождения Ю.И. Полянского (XXXII конференция молодыХ ученых ММБИ) (г. Мурманск, май 2014). - Мурманск: Изд. ММБИ КНЦ РАН, 2014. C. $129-136$.

256. Пуговкин Д.В. Сравнительный анализ методов десорбции эпифитных бактерий // Материалы XXIX конференции молодых ученых Мурманского морского биологического института, посвященной 140летию со дня рождения Г.А. Клюге, «Морские исследования экосистем европейской Арктики» (г. Мурманск, май 2011 г.). - Мурманск: Изд. ММБИ КНЦ РАН, 2011. - С. 177-180.

257. Пуговкин Д.В. Эпифитные бактерии бурых водорослей Баренцева моря // Биоресурсы и аквакультура: Тез. докл. Школы молодых ученых по морской биологии (Мурманск, 28-29 февраля 2012 г.). Мурманск: Изд-во Мурм. гос. техн. ун-та, 2012. - С. 36-37.

258. Пуговкин Д.В., Ляймер А.В. Бактерии-эпифиты водорослей Fucus vesiculosus в губе Дальнезеленецкая Баренцева моря // Арктическое морское природопользование в XXI веке - современный баланс научных традиций и инноваций (к 80-летию ММБИ КНЦ РАН): Тез. докл. Междунар. науч. конф. (г. Мурманск, 1-3 апреля 2015 г.). Апатиты: Изд-во КНЦ РАН, 2015. - С. 204-205.

259. Пуговкин Д.В., Ильинский В.В., Ляймер А.В. Таксономический состав эпифитных бактериоцензов бурых водорослей Fucus vesiculosus 
из чистых и загрязненных нефтепродуктами акваторий Баренцева моря // Современные проблемы физиологии, экологии и биотехнологии микроорганизмов: Матер. Всерос. симп. с междунар. участием (г. Москва, 24-27 декабря 2014 г.). - М.: МАКС Пресс, 2014. - С. 191.

260. Пуговкин Д.В., Ильинский В.В., Ляймер А.В. Эпифитные бактериальные сообщества бурых водорослей Fucus vesiculosus Баренцева моря // Охрана окружающей среды и здоровья человека в Российской Федерации и странах Евросоюза: Матер. Междунар. науч.-практ. конф. (г. Мурманск, 31 октября 2014 г.). - Мурманск: Изд-во Мурм. гос. техн. ун-та, 2014. - С. 134-134.

261. Пуговкин Д.В., Рыюжик И.В., Воскобойников Г.М. Эффективность деструкции нефтяных углеводородов бактериально-водорослевой ассоциацией (БВА) в лабораторных условиях // Актуальные проблемы науки и техники - 2015: Матер. VIII Междунар. науч.-практ. конф. молодых ученых (16-18 ноября 2015 г.). - Уфа: Изд-во Уфимского гос. нефт. техн. ун-та, 2015. - Т. I. - C. 341-342.

262. Широколобова Т.И. Микробиологический мониторинг фоновых и импактных районов Баренцевоморского прибрежья // Экологическая безопасность приморских регионов (порты, берегозащита, рекреация, марикультура): Матер. Междунар. науч. конф., посвященной 150-летию Н.М. Книповича (Ростов-на-Дону, 5-8 июня 2012 г.). - Ростов н/Д.: Изд-во ЮНЦ РАН, 2012. - С. 278-281.

263. Широколобова Т.И., Венгер М.П. Микробиологический мониторинг прибрежных вод Баренцева моря // Глобальные климатические процессы и их влияние на экосистемы арктических и субарктических регионов: Тез. докл. Междунар. науч. конф. (г. Мурманск, 9-11 ноября 2011 г.). - Апатиты: Изд-во КНЦ РАН, 2011. - C. 202-203.

\section{Фитопланктон. Первичная продукция}

264. Бардан С.И. Фракционирование по размеру клеток фитоценозов зимнего планктона и полуэмпирическая модель процесса для подледного периода // Экологическая безопасность приморских регионов (порты, берегозащита, рекреация, марикультура): Матер. Междунар. науч. конф., посвященной 150-летию Н.М. Книповича (Ростов-на-Дону, 5-8 июня 2012 г.). - Ростов н/Д.: Изд-во ЮНЦ РАН, 2012. - C. 51-55.

265. Водопьянова В.В. Пространственное распределение хлорофилла $a$ фитопланктона на акватории Баренцева моря в августе 
2010 г. // Материалы XXIX конференции молодых ученых Мурманского морского биологического института, посвященной 140летию со дня рождения Г.А. Клюге, «Морские исследования экосистем европейской Арктики» (г. Мурманск, май 2011 г.). - Мурманск: Изд. ММБИ КНЦ РАН, 2011. - С. 38-42.

266. Водопьянова В.B. Вертикальное распределение хлорофилла арктического фитопланктона в условиях полярной ночи // Арктическое морское природопользование в XXI веке - современный баланс научных традиций и инноваций (к 80-летию ММБИ КНЦ РАН): Тез. докл. Междунар. науч. конф. (г. Мурманск, 1-3 апреля 2015 г.). Апатиты: Изд-во КНЦ РАН, 2015. - С. 30-31.

267. Дружкова Е.И. Биопродуктивность и фитопланктонные сообщества Баренцева, Белого и Карского морей // Комплексные исследования больших морских экосистем России. - Апатиты: Изд-во КНЦ РАН, 2011. - С. 116-154.

268. Дружкова Е.И. Пространственная организация сообщества нанопланктона фьордов Западного Шпицбергена // Глобальные климатические процессы и их влияние на экосистемы арктических и субарктических регионов: Тез. докл. Междунар. науч. конф. (г. Мурманск, 9-11 ноября 2011 г.). - Апатиты: Изд-во КНЦ РАН, 2011. - C. 54-56.

269. Дружкова Е.И., Макаревич П.Р. Исследования фитопланктона моря Лаптевых: история и современность // Тр. Кольского науч. центра РАН. - 2013. - Т. 1(14). - Сер. Океанология. - Вып. 1. - С. 71-79.

270. Ларионов В.В. Сообщества одноклеточных микроводорослей: «третий» путь эволюции // Арктическое морское природопользование в XXI веке - современный баланс научных традиций и инноваций (к 80-летию ММБИ КНЦ РАН): Тез. докл. Междунар. науч. конф. (г. Мурманск, 1-3 апреля 2015 г.). - Апатиты: Изд-во КНЦ РАН, 2015. C. $130-132$.

271. Макаревич П.Р. Первичная продуктивность прибрежных экосистем Баренцева моря // Глобальные климатические процессы и их влияние на экосистемы арктических и субарктических регионов: Тез. докл. Междунар. науч. конф. (г. Мурманск, 9-11 ноября 2011 г.). Апатиты: Изд-во КНЦ РАН, 2011. - С. 120-121.

272. Макаревич П.Р. Первичная продукция Баренцева моря // Вестн. Мурм. гос. техн. ун-та. - 2012. - Т. 15, № 4. - С. 786-793.

273. Макаревич П.Р. Особенности функционирования сообществ первичных продуцентов морей Западной Арктики // Арктическое морское природопользование в XXI веке - современный баланс научных традиций и инноваций (к 80-летию ММБИ КНЦ РАН): Тез. докл. 
Междунар. науч. конф. (г. Мурманск, 1-3 апреля 2015 г.). - Апатиты: Изд-во КНЦ РАН, 2015. - С. 146-147.

274. Макаревич П.Р. Структура годового цикла пелагических альгоценозов прибрежной зоны Карского моря // Экосистема Карского моря - новые данные экспедиционных исследований: Матер. науч. конф. (Москва, 27-20 мая 2015 г.). - М.: АПР, 2015. - С. 98-105.

275. Макаревич П.Р., Дружкова Е.И. Первичная продукция Баренцева моря // Изучение и освоение морских и наземных экосистем в условиях арктического и аридного климата: Матер. Междунар. науч. конф. (6-11 июня 2011 г., Ростов-на-Дону). - Ростов н/Д.: Изд-во ЮНЦ PAH, 2011. - C. 180-182.

276. Макаревич П.Р., Ларионов В.В. Годовой цикл развития планктонного фитоценоза Обь-Енисейского мелководья Карского моря // Биология моря. - 2011. - Т. 37, № 1. - С. 3-8.

277. Макаревич П.Р., Водопьянова В.В., Олейник А.А. Фитоценозы пелагиали Кольского залива. Структура и функциональные характеристики. - Ростов н/Д.: Изд-во ЮНЦ РАН, 2015. - 192 с.

278. Макаревич П.Р., Дружкова Е.И., Ларионов В.В. Первичный продукционный потенциал пелагиали прибрежной зоны архипелага Земля Франца-Иосифа // Комплексные исследования природы Шпицбергена и прилегающего шельфа: Матер. Междунар. науч. конф. (Мурманск, 6-8 ноября 2014 г.). Вып. 12. - М.: ГЕОС, 2014. - С. 178-182.

279. Макаревич П.Р., Дружкова Е.И., Ларионов В.В. Структура сезонной сукцессии фитопланктона Баренцева и Карского морей: регуляция или саморегуляция? // Морские экосистемы и сообщества в условиях современных климатических изменений. - СПб.: Реноме, 2014. - C. 99-121.

280. Олейник A.A. Продукционный цикл фитопланктона в эстуарии Кольского залива // Глобальные климатические процессы и их влияние на экосистемы арктических и субарктических регионов: Тез. докл. Междунар. науч. конф. (г. Мурманск, 9-11 ноября 2011 г.). - Апатиты: Изд-во КНЦ РАН, 2011. - С. 140-141.

281. Олейник A.A. Сезонное развитие фитопланктона в водах желоба Франц-Виктория и на прилегающей акватории архипелага Земля Франца-Иосифа // Наземные и морские экосистемы. - М.; СПб.: Paulsen, 2011. - C. 166-180.

282. Олейник А.А. Фитопланктон Кольского залива: Автореф. дис. ... канд. биол. наук (25.00.28 - океанология). - Мурманск, 2011. - 23 с. 
283. Олейник A.A. Весеннее развитие микропланктона во фьордах Западного Шпицбергена // Комплексные исследования природы Шпицбергена: Матер. Междунар. науч. конф. (Мурманск, 1-3 ноября 2012 г.). Вып. 11. - М.: ГЕОС, 2012. - С. 206-209.

284. Олейник A.A. Новые динофлагеллаты (Dinophyceae) планктона Баренцева моря // Бот. журн. - 2014. - Т. 99, № 7. - C. 756-765.

285. Олейник A.A. Фитопланктон прибрежья архипелага Земля Франца-Иосифа // Вестн. Кольского науч. центра РАН. - 2015. № 2(21). - C. 25-32.

286. Павлова М.А. Вспышка цветения кокколитофорид в прибрежных районах Баренцева моря [Электронный ресурс] // Наука и образование - 2013: Матер. Междунар. науч.-техн. конф., Мурманск, 4-11 марта 2013 г. - Электрон. текст. дан. (220 Мб). - Мурманск: Издво Мурм. гос. техн. ун-та, 2013. - С. 273-275. - 1 электрон. опт. диск (CD-ROM). - Систем. требования: PC не ниже класса Pentium II; 128 Mb RAM; свободное место на HDD $130 \mathrm{Mb}$; дисковод CD-ROM 2-х и выше. - Загл. с экрана. - Электрон. текст подг. ФГБОУ ВПО «МГТУ». № гос. регистрации 0321301202 .

287. Павлова М.А., Водопьянова В.В., Олейник А.А. Особенности развития микробиоценозов пелагиали Обско-Тазовской губы // Современные проблемы физиологии, экологии и биотехнологии микроорганизмов: Всерос. симп. с междунар. участием (г. Москва, МГУ, 24-27 декабря 2014 г.). - М.: МАКС Пресс, 2014. - С. 179.

288. Сапрыгин B.B. Изучение распределения хлорофилла $a$ в Азовском море по данным дистанционного зондирования Земли из космоса и результатам судовых измерений: Автореф. дис. ... канд. геогр. наук (25.00.28 - океанология). - Ростов н/Д., 2011. - 24 с.

289. Структура и распределение фитопланктона в глубоководных районах северной части Карского моря / В.М. Суханова, И.Н. Суханова, Е.И. Дружкова, А.Ф. Сажин, А.Б. Демидов, С.А. Мошаров, В.В. Кременецкий, А.С. Полухин // Экосистема Карского моря - новые данные экспедиционных исследований: Матер. науч. конф. (Москва, 27-29 мая 2015 г.). - М.: АПР, 2015. - С. 98-105.

290. Структура сообществ фитопланктона Енисейского эстуария и прилежащего Карского шельфа / И.Н. Суханова, М.В. Флинт, B.М. Сергеева, Е.И. Дружкова, А.А. Недоспасов // Океанология. - 2015. Т. 55, № 6. - С. 935-948.

291. Фитопланктон северо-западной части Карского моря / И.Н. Суханова, М.В. Флинт, Е.И. Дружкова, А.Ф. Сажин, В.М. Сергеева // Океанология. - 2015. - Т. 55, № 4. - С. 605-619. 
292. Фитоценозы эстуариев Оби и Енисея и Обь-Енисейского взморья / И.Н. Суханова, М.В. Флинт, В.М. Сергеева, Е.И. Дружкова // Экосистема Карского моря - новые данные экспедиционных исследований: Матер. науч. конф. (Москва, 27-29 мая 2015 г.). - М.: АПР, 2015. - С. 105-111.

293. Широколобова Т.И., Водопьянова В.В., Павлова М.А. Современные изменения в планктонном фитоценозе Баренцевоморского прибрежья // Состояние арктических морей и территорий в условиях изменения климата: Тез. Всерос. конф. с междунар. участием. Архангельск: Изд. дом САФУ, 2014. - С. 109-110.

294. Druzhkova E.I., Makarevich P.R. The Laptev Sea phytoplankton studies: past and present // Berichte zur Polarforschung. - 2012. - № 640. P. 74-80.

295. Makarevich P., Druzhkova E., Larionov V. Primary producer of the Barents Sea // Diversity of Ecosystems. - Rijeka, Croatia: IntechOpen, 2012. - P. 367-392.

296. Makarevich P., Larionov V., Moiseev D. The pelagic algocenosis in the Ob-Yenisei shallow zone of the Kara Sea: Productive potential and the features of the succession cycle [Электронный pecypc] // Arctic Frontiers 2015. Climate and Energy: Sci. conf. (Tromsø, Norway, 18-23 January 2015). - Tromsø, 2015. - P. 137. - URL: http://arcticfrontiers. conference-sevices.net/reports/template/onetextabstract.xml?xsl=template/ onetextabstract.xsl\&conferenceID $=4282 \&$ abstractID $=866014$

297. Makarevich P.R., Larionov V.V., Moiseev D.V. Phytoplankton succession in the Ob-Yenisei shallow zone of the Kara Sea based on russian databases // J. Sea Res. - 2014. - Vol. 101 (Special iss.: The changing North Sea: Taking stock). - P. 31-40. - Doi: 10.1016/j.seares.2014.10.008. URL: http://www.sciencedirect.com/science/article/pii/S1385110114001816

298. Phytoplankton community structure in the Lena Delta (Siberia, Russia) in relation to hydrography / A.C. Kraberg, E. Druzhkova, B. Heim, M.J.G. Loeder, K.H. Wiltshire // Biogeosciences Discuss. - 2013. - Vol. 10, № 2. - P. 2305-2344. - Doi: 10.5194/bgd-10-2305-2013. - URL: http:// www.biogeosciences-discuss.net/10/issue2.html

299. Phytoplankton in the northwestern Kara Sea / I.N. Sukhanova, M.V. Flint, A.F. Sazhin, V.M. Sergeeva, E.I. Druzhkova // Oceanology. 2015. - Vol. 55, № 4. - P. 547-560.

300. The molecular characterization of the enigmatic dinoflagellate Kolkwitziella acuta reveals an affinity to the excentrica section of the genus Protoperidinium / K.N. Mertens, Y. Takano, A. Yamaguchi, H. Gu, K. Bogus, A. Kremp, S. Bagheri, G. Matishov, K. Matsuoka // Systematics and 
Biodiversity. - 2015. - Vol. 13, № 2. - P. 116. - Doi: 10.1080/14772000. 2015.1078855. - URL: http://www.tandfonline.com/doi/full/10.1080/14772000. 2015.1078855 (IF-2.191)

\section{Зоопланктон}

301. Берченко И.В. Некоторые морфологические особенности вида Calanus finmarchicus (Copepoda) // Материалы XXIX конференции молодых ученых Мурманского морского биологического института, посвященной 140-летию со дня рождения Г.А. Клюге, «Морские исследования экосистем европейской Арктики» (г. Мурманск, май 2011 г.). - Мурманск: Изд. ММБИ КНЦ РАН, 2011. - С. 16-19.

302. Берченко И.В. Внутривидовая изменчивость некоторых морфологических признаков Calanus finmarchicus (Copepoda) в морях Западной Арктики // Докл. РАН. - 2012. - Т. 442, № 3. - С. 423-425.

303. Берченко И.В. Межвидовое скрещивание в популяциях Calanus finmarchicus и Calanus glacialis арктических морей // Материалы XXXI конференции молодых ученых Мурманского морского биологического института, посвященной 135-летию со дня рождения К.М. Дерюгина, «Океанография и биология арктических морей» (г. Мурманск, май 2013). - Мурманск: Изд. ММБИ КНЦ РАН, 2013. - С. 21-25.

304. Берченко И.В., Бобров К.А. Ранневесенние процессы в планктоне Грён-фьорда (Ис-фьорд, арх. Шпицберген) // Комплексные исследования природы Шпицбергена и прилегающего шельфа: Матер. Междунар. науч. конф. (Мурманск, 6-8 ноября 2014 г.). Вып. 12. - М.: ГЕОС, 2014. -. 27-30.

305. Берченко И.В., Ступникова А.Н. Морфологические особенности Calanus finmarchicus и Calanus glacialis в районах совместного существования популяций // Океанология. - 2014. - Т. 54, № 4. - С. 490-497.

306. Дворецкий В.Г. Динамика биомассы зоопланктона и Calanus finmarchicus в прибрежной зоне Баренцева моря в условиях климатических вариаций // Глобальные климатические процессы и их влияние на экосистемы арктических и субарктических регионов: Тез. докл. Междунар. науч. конф. (г. Мурманск, 9-11 ноября 2011 г.). Апатиты: Изд-во КНЦ РАН, 2011. - С. 33-34.

307. Двореикий В.Г. Межгодовые вариации трофической структуры и биоразнообразия зоопланктонных сообществ в южной части Баренцева моря // Изв. ТИНРО. - 2011. - Т. 165. - С. 185-195. 
308. Двореикий В.Г. Мониторинговые исследования зоопланктона в губе Долгая Баренцева моря // Изучение и освоение морских и наземных экосистем в условиях арктического и аридного климата: Матер. Междунар. науч. конф. (6-11 июня 2011 г., Ростов-на-Дону). Ростов н/Д.: Изд-во ЮНЦ РАН, 2011. - С. 265-267.

309. Дворецкий В.Г. Распределение личинок эвфаузиид и десятиногих ракообразных в весеннем планктоне южной части Баренцева моря // Изв. РАН. Сер. биол. - 2011. - № 4. - С. 463-469.

310. Дворецкий В.Г. Структура зоопланктонного сообщества в Воронке и Мезенском заливе летом 2008 г. // Материалы XXIX конференции молодых ученых Мурманского морского биологического института, посвященной 140 -летию со дня рождения Г.А. Клюге, «Морские исследования экосистем европейской Арктики» (г. Мурманск, май 2011 г.). - Мурманск: Изд. ММБИ КНЦ РАН, 2011. - С. 61-65.

311. Двореикий В.Г. Зимний зоопланктон Карского моря (февраль 2002 г.) // Материалы Всероссийской конференции молодых ученых и специалистов с международным участием, посвященной 90-летию со дня постройки первого научно-исследовательского судна ПИНРО «Персей». - Мурманск: Изд-во ПИНРО, 2012. - С. 80-84.

312. Дворецкий В.Г. Продукция кормового зоопланктона в Баренцевом море в летний период // Изв. ТИНРО. - 2012. - Т. 168. - С. 169-183.

313. Дворецкий В.Г. Размерная структура популяций Calanus finmarchicus, C. glacialis и C. hyperboreus во внутренних водах архипелага Земля Франца-Иосифа в августе 2006 и 2007 гг. // Проблемы Арктики и Антарктики. - 2012. - № 3. - С. 28-39.

314. Дворецкий В.Г. Структура популяции и скорость продукции яиц Temora longicornis (Copepoda) в губе Дальнезеленецкая (Баренцево море) в середине летнего периода // Вестн. СПбГУ. Сер. 3. - 2012. Вып. 2. - С. 35-43.

315. Двореикий В.Г. Зимний зоопланктон прибрежья югозападной части Баренцева моря (март 2007 г.) // Материалы XXX юбилейной конференции молодых ученых Мурманского морского биологического института, посвященной 150 -летию со дня рождения Н.M. Книповича, «Проблемы океанографии, биологии и освоения биоресурсов морей российской Арктики» (г. Мурманск, май 2012). Мурманск: Изд. ММБИ КНЦ РАН, 2012. - С. 49-57.

316. Дворецкий В.Г. Современные исследования зоопланктона в Баренцевом море // Тр. Кольского науч. центра РАН. - 2013. Т. 1(14). - Сер. Океанология. - Вып. 1. - С. 161-182. 
317. Дворецкий В.Г. Структура летних сообществ мезозоопланктона у берегов архипелага Земля Франца-Иосифа и в прилегающих водах // Тр. Кольского науч. центра РАН. 2014. - Т. 4(23). - Сер. Океанология. Вып. 2. - С. 150-179.

318. Двореикий В.Г. Особенности распределения зимнего зоопланктона в Печорском море // Вестн. Кольского науч. центра РАН. - 2015. № 3(23). - C. 73-81.

319. Дворецкий В.Г., Дворецкий А.Г. Биология и роль Oithona similis в зоопланктоне морей Арктики. - Апатиты: Изд-во КНЦ РАН, 2011. - 149 c.

320. Дворецкий В.Г., Дворецкий А.Г. Смертность планктонного рачка Oithona similis Claus, 1866 (Copepoda: Cyclopoida) в Баренцевом и Белом морях // Биология моря. - 2011. - Т. 37, № 2. - С. 116-123.

321. Двореикий В.Г., Дворецкий А.Г. Динамика биомассы зоопланктона и Calanus finmarchicus в прибрежье Баренцева моря в различных термических условиях // Изв. РАН. Сер. Биол. - 2012. № 6. - С. 667-672.

322. Дворецкий В.Г., Дворецкий А.Г. Распределение копепод в весеннем планктоне прибрежья Баренцева моря в 2007 г. // Вестн. Кольского науч. центра РАН. - 2012. - № 2(9). - С. 30-36.

323. Дворецкий В.Г., Дворецєкий А.Г. Структура эпизоопланктона и уровни продукции копепод в северо-восточной части Черного моря (лето 2010 г.) // Вестн. Южного науч. центра РАН. - 2012. - Т. 8, № 2. C. $48-52$.

324. Дворецкий В.Г., Двореикий А.Г. Особенности биологии ракообразных, ассоциированных с морским льдом в Арктике (обзор) // Вестн. Кольского науч. центра РАН. - 2013. - № 1. - С. 43-57.

325. Дворецкий В.Г., Дворецкий А.Г. Суточная продукция Acartia longiremis в Баренцевом море в летний период // Изв. ТИНРО. - 2013. T. 175. - C. 1-7.

326. Дворецкий В.Г., Дворецкий А.Г. Уровни смертности двух массовых копепод в Баренцевом море // Вестн. Мурм. гос. техн. ун-та. 2013. - Т. 16, № 3. - С. 460-465.

327. Дворецкий В.Г., Дворецкий А.Г. Распределение зоопланктона в прибрежье Кольского полуострова летом 2012 г. // Материалы XXXI конференции молодых ученых Мурманского морского биологического института, посвященной 135-летию со дня рождения К.М. Дерюгина, «Океанография и биология арктических морей» (г. Мурманск, май 2013). - Мурманск: Изд. ММБИ КНЦ РАН, 2013. - С. 49-56. 
328. Двореикий В.Г., Двореикий А.Г. Генеративная продукция планктонного рачка Pseudocalanus minutus в прибрежье Баренцева моря // Бюл. Моск. общ-ва испытателей природы. Отд. биол. - 2013. Т. 118, вып. 4. - С. 34-38.

329. Дворецкий В.Г., Двореикий А.Г. Сезонные вариации репродуктивных характеристик Oithona similis (Copepoda, Cyclopoida) в Кольском заливе // Материалы XV Школы-конференции молодых ученых «Биология внутренних вод» (Борок, 19-24 октября 2013 г.). Кострома: Костромской печатный дом, 2013. - С. 52-55.

330. Двореикий В.Г., Дворецкий А.Г. Зимний зоопланктон югозападной части Баренцева моря (март 2007 г.) // Рыбное хозяйство. 2013. - № 2. - С. 74-78.

331. Дворецкий В.Г., Двореикий А.Г. Годовой продукционный цикл зоопланктона в южной части Баренцева моря // Проблемы Арктики и Антарктики. - 2014. - № 4. - С. 90-96.

332. Дворецкий В.Г., Дворечкий А.Г. Биоразнообразие и трофическая структура зоопланктона в Баренцевом море // Морские экосистемы и сообщества в условиях современных климатических изменений. - СПб.: Реноме, 2014. - С. 121-131.

333. Двореикий В.Г., Дворецкий А.Г. Видовое разнообразие планктонных сообществ западноарктических морей // Биология моря. 2014. - T. 40, № 2. - С. 108-112.

334. Дворецкий В.Г., Двореикий А.Г. Генеративная продукция массовой планктонной копеподы Calanus finmarchicus в прибрежье Баренцева моря // Вестн. Мурм. гос. техн. ун-та. - 2014. - Т. 17, № 1. C. 112-117.

335. Двореикий В.Г., Двореикий А.Г. Межгодовая флуктуация зоопланктона на Кольском разрезе (Баренцево море) в связи с факторами среды // Изв. РАН. Сер. Биол. - 2014. - № 4. - С. 398-407.

336. Дворецุкий В.Г., Дворецкий А.Г. Распределение зоопланктона в прибрежных водах архипелага Шпицберген в августе 2009 г. // Комплексные исследования природы Шпицбергена и прилегающего шельфа: Матер. Междунар. науч. конф. (Мурманск, 6-8 ноября 2014 г.). Вып. 12. - М.: ГЕОС, 2014. - С. 58-63.

337. Двореикий В.Г., Двореикий А.Г. Сообщество планктонных копепод губы Ура и прилегающих вод // Эколого-эволюционные исследования морских организмов и экосистем: Матер. XIV Междунар. науч. конф. студентов и аспирантов «Проблемы Арктического региона» (г. Мурманск, май 2014 г.). Т. І. Форум молодых ученых, посвященный 110-летию со дня рождения Ю.И. Полянского (XXXII конференция молодых ученых ММБИ). - Мурманск: Изд. ММБИ КНЦ РАН, 2014. С. 54-63. 
338. Двореикий В.Г., Двореикий А.Г. Влияние факторов среды на зоопланктон на разрезе «Кольский меридиан» в 2003-2010 гг. // Арктическое морское природопользование в XXI веке - современный баланс научных традиций и инноваций (к 80-летию ММБИ КНЦ РАН): Тез. докл. Междунар. науч. конф. (г. Мурманск, 1-3 апреля 2015 г.). Апатиты: Изд-во КНЦ РАН, 2015. - С. 48-50.

339. Двореикий В.Г., Двореикий А.Г. Продукционные характеристики зоопланктона южного прибрежья Баренцева моря (губа Дроздовка) // Вестн. Южного науч. центра РАН. - 2015. - Т. 11, № 3. - С. 92-97.

340. Дворецкий В.Г., Дворецкий А.Г. Распределение и продукционные характеристики кормового зоопланктона у берегов Кольского полуострова летом 2008 года // Рыбное хозяйство. - 2015. - № 1. - С. 59-63.

341. Двореикий В.Г., Дворецฺкий А.Г. Зоопланктон в районах формирования полыней в морях Северного Ледовитого океана // Биология моря. - 2015. - Т. 41, № 4. - С. 225-238.

342. Дворецкий В.Г., Дворецкий А.Г. Межгодовые колебания численности и биомассы планктонных копепод рода Oithona в Баренцевом море // Изв. РАН. Сер. Биол. - 2015. - № 5. - С. 528-537. Doi: $10.1134 / \mathrm{S} 1062359015050052$

343. Дворецкий В.Г., Дворецкий А.Г. Экология зоопланктонных сообществ Баренцева моря и сопредельных вод. - СПб.: Реноме, 2015. - 736 c.

344. Кренева К.B., Кренева C.В. «Микробиальная петля» и микрозоопланктон // Биосистема: от теории к практике: Тез. докл. Школы-конф. молодых ученых. - Пущино, 2013. - С. 81.

345. Кренева С.В., Кренева К.В. Уровень развития планктонных инфузорий как показатель адаптации экосистем к эвтрофированию вод // Экология свободноживущих простейших наземных и водных экосистем: Тез. докл. IV Междунар. симп. (г. Тольятти, 17-21 октября 2011 г.). - Тольятти: Кассандра, 2011. - С. 35.

346. Летний бактерио- и зоопланктон прибрежных вод архипелага Шпицберген / В.Г. Двореикий, М.П. Венгер, П.Р. Макаревич, Д.В. Моисеев // Биология моря. - 2012. - Т. 38, № 1. - С. 82-85.

347. Berchenko I., Stupnikova A. Interbreeding of Calanus finmarchicus and C. glacialis in the areas of coexisting // Arctic Frontiers 2013. Geopolitics and marine production in a cangini Arctic: Abstr. book (Tromsø, Norway, 20-25 January 2013). - Tromsø, 2013. - P. 157.

348. Dvoretsky V.G. Distribution of Calanus species off Franz Josef Land (Arctic Barents Sea) [Электронный pecypc] // Polar Sci. - 2011. Vol. 5. - P. 361-373. - Doi: 10.1016/j.polar.2011.06.004. - URL: http:// www.sciencedirect.com/science/article/pii/S1873965211000521 
349. Dvoretsky V.G. Seasonal mortality rates of Oithona similis (Cyclopoida) in a large Arctic fjord // Polar Sci. - 2012. - Vol. 6. - P. 263269. - Doi: 10.1016/j.polar.2012.09.001. - URL: http://www.sciencedirect. com/science/article/pii/S1873965212000424

350. Dvoretsky V.G., Dvoretsky A.G. Crustaceans of the Barents Sea: recent studies of Murmansk Marine Biological Institute: review // Berichte zur Polarforschung. - 2012. - № 640. - P. 162-176.

351. Dvoretsky V.G., Dvoretsky A.G. Morphometric differentiation of Pseudocalanus minutus populations in the Barents Sea // Acta Zoologica. 2013. - Vol. 94, iss. 2. - P. 203-214. - Doi: 10.1111/j.1463-6395.2011.00543.x URL: http://onlinelibrary.wiley.com/doi/10.1111/j.1463-6395.2011.00543.x/abstract

352. Dvoretsky V.G., Dvoretsky A.G. Copepod communities off Franz Josef Land (northern Barents Sea) in late summer of 2006 and 2007 // Polar Biol. - 2011. - Vol. 34. - P. 1231-1238. - Doi: 10.1007/s00300-011-0977-2. URL: http://www.springerlink.com/content/dkt82274760gw686/

353. Dvoretsky V.G., Dvoretsky A.G. Mesozooplankton structure in the northern White Sea in July 2008 // Polar Biol. - 2011. - Vol. 34, № 3. P. 469-474. - Doi: 10.1007/s00300-010-0901-1. - URL: http://www.springerlink. com/content/6646387p87k5225w/fulltext.html

354. Dvoretsky V.G., Dvoretsky A.G. Estimated copepod production rate and structure of mesozooplankton communities in the coastal Barents Sea during summer-autumn 2007 // Polar Biol. - 2012. - Vol. 12, № 9. P. 1321-1342. - Doi: 10.1007/s00300-012-1175-6. - URL: http://www. springerlink.com/content/678x372631401t67/

355. Dvoretsky V.G., Dvoretsky A.G. Epiplankton in the Barents Sea: Summer variations of mesozooplankton biomass, community structure and diversity // Continental Shelf Res. - 2013. - Vol. 52, № 1. - P. 1-11. Doi: 10.1016/j.csr.2012.10.017. - URL: http://www.sciencedirect.com/science/ article/pii/S0278434312002932

356. Dvoretsky V.G., Dvoretsky A.G. Structure of mesozooplankton community in the Barents Sea and adjacent waters in August 2009 // J. Natur. History. - 2013. - Vol. 47, № 31-32. - P. 2095-2114.

357. Dvoretsky V.G., Dvoretsky A.G. Summer mesozooplankton community of Moller Bay (Novaya Zemlya Archipelago, Barents Sea) // Oceanologia. - 2013. - Vol. 55, № 1. - P. 205-218. - Doi: 10.5697/oc.551.205. - URL: http://www.iopan.gda.pl/oceanologia/

358. Dvoretsky V.G., Dvoretsky A.G. Egg production rates of two common copepods in the Barents Sea in summer // Polar Sci. - 2014. Vol. 8. - 298-305. 
359. Dvoretsky V.G., Dvoretsky A.G. Zooplankton in the Areas of Polynya Formation in the Seas of the Arctic Ocean // Russian J. Marine Biol. - 2015. Vol. 41, № 4. - P. 223-237.

360. Dvoretsky V.G., Dvoretsky A.G. Early winter mesozooplankton of the coastal south-eastern Barents Sea // Estuarine, Coastal and Shelf Science. - 2015. - Vol. 152. - P. 116-123. - Doi: 10.1016/j.ecss.2014.11.016. URL: http://www.sciencedirect.com/science/article/pii/S0272771414003448

361. Dvoretsky V.G., Dvoretsky A.G. Interannual variations in abundance and biomass of planktonic copepods Oithona in the Barents Sea // Biology Bull. - 2015. - Vol. 42, № 5. - P. 449-457. - Doi: 10.1134/ S1062359015050052

362. Dvoretsky V.G., Dvoretsky A.G. Regional differences of mesozooplankton communities in the Kara Sea // Continental Shelf Res. 2015. - Vol. 105. - P. 26-41.

363. Dvoretsky V.G., Dvoretsky A.G. Summer population structure of the copepods Paraeuchaeta spp. in the Kara Sea // J. Sea Res. - 2015. Vol. 96. - P. 18-22.

364. Selifonova Zh.P. Seasonal dynamics of micro- and mesoplankton of the Temryuk estuarial pelagic ecosystem of the Sea of Azov // Inland Water Biology. - 2011. - Vol. 4, № 2. - P. 182-191.

\section{Зообентос}

365. Ахметчина О.Ю. Современные данные о видовом составе и распределении мшанок (Bryozoa) вдоль разреза «Кольский меридиан» (Баренцево море) // Материалы XXXI конференции молодых ученых Мурманского морского биологического института, посвященной 135летию со дня рождения К.М. Дерюгина, «Океанография и биология арктических морей» (г. Мурманск, май 2013). - Мурманск: Изд. ММБИ КНЦ РАН, 2013. - С. 8-17.

366. Ахметчина О.Ю. Видовой состав и особенности распределения мшанок в заливе Хорнсунн (Западный Шпицберген) // Экологоэволюционные исследования морских организмов и экосистем: Матер. XIV Междунар. науч. конф. студентов и аспирантов «Проблемы Арктического региона» (г. Мурманск, май 2014 г.). Т. I. Форум молодых ученых, посвященный 110 -летию со дня рождения Ю.И. Полянского (XXXII конференция молодых ученых ММБИ). Мурманск: Изд. ММБИ КНЦ РАН, 2014. - С. 10-16. 
367. Ахметчина О.Ю. Мшанки залива Хорнсунн-фьорд (Западный Шпицберген) // Современные проблемы экологии и природопользования: Матер. регион. науч.-практ. конф., посвященной 15-летию со дня основания кафедры биоэкологии, Мурманск, 27-28 февраля 2014 г. Мурманск: Изд-во Мурм. гос. техн. ун-та, 2014. - С. 74-79.

368. Ахметчина О.Ю. Биотопическое распределение мшанок (Bryozoa) на литорали Восточного Мурмана (Дальние Зеленцы) // Арктическое морское природопользование в XXI веке - современный баланс научных традиций и инноваций (к 80-летию ММБИ КНЦ РАН): Тез. докл. Междунар. науч. конф. (г. Мурманск, 1-3 апреля 2015 г.). Апатиты: Изд-во КНЦ РАН, 2015. - С. 12-14.

369. Ахметчина О.Ю., Захаров Д.В. Видовой состав и распределение мшанок (Bryozoa) вдоль разреза «Кольский меридиан» (Баренцево море) в 2010-2011 годах // Вестн. Мурм. гос. техн. ун-та. - 2013. - Т. 16, № 3. - C. 415-424.

370. Бентосные сообщества архипелага Земля Франца-Иосифа / Е.А. Фролова, О.Ю. Ахметчина, Е.А. Гарбуль, Д.Р. Дикаева, О.Л. Зимина, О.С. Любина, И.О. Нехаев, Н.Н. Пантелеева, А.А. Фролов // Тр. Кольского науч. центра РАН. - 2014. - Т. 4(23). - Сер. Океанология. Вып. 2. - С. 179-222.

371. Бирюкова C.B. Макрозообентос районов косы Тузла и косы Рубанова Таманского залива // Арктическое морское природопользование в XXI веке - современный баланс научных традиций и инноваций (к 80-летию ММБИ КНЦ РАН): Тез. докл. Междунар. науч. конф. (г. Мурманск, 1-3 апреля 2015 г.). - Апатиты: Изд-во КНЦ РАН, 2015. - C. 21-23.

372. Булышева Н.И., Набоженко М.В., Шохин И.В. Изученность фауны донных беспозвоночных республики Адыгея // Социальногуманитарные и экологические проблемы развития современной Адыгеи. - Ростов н/Д.: Изд-во ЮНЦ РАН, 2012. - С. 316-319.

373. Бульшева Н.И., Набоженко М.В., Шохин И.В. Многолетние изменения донных сообществ кавказской части Черного моря // Биологическое разнообразие Кавказа: Матер. XIV Междунар. науч. конф., посвященной 70-летию со дня рождения Гайирбега Магомедовича Абдурахманова (Махачкала, 5-7 ноября 2012). - Махачкала: Изд-во Ин-та прикладной экологии Республики Дагестан, 2012. - С. 383-384.

374. Винарский М.В., Нехаев И.О., Палатов Д.М. Находки моллюсков рода Aplexa (Gastropoda: Pulmonata: Physidae) в водоемах крайнего севера Западной Сибири // Бюл. Дальневосточного малакологического общ-ва. - 2013. - Вып. 17. - С. 142-150. 
375. Ворошилова И.С., Фролов А.А., Андреева С.И. Соответствует ли форма раковин сфериид логарифмической спирали? // Экосистемы малых рек: биоразнообразие, экология, охрана: Матер. лекций II Всерос. школы-конф. (пос. Борок, 18-22 ноября 2014 г.). - Т. II. Борок: Филигрань, 2014. - С. 70-72.

376. Вязникова В.С., Манушин И.Е., Фролова Е.А. Две стратегии существования полихет в Баренцевом море на примере Spiochaetopterus typicus и видов семейства Maldanidae // Материалы XVII научного семинара «Чтения памяти К.М. Дерюгина». - СПб.: Изд-во СПбГУ, 2015. - C. 52-68.

377. Гарбуль Е.А., Любина О.С. Оценка уловистости дночерпателей разных типов на песчаных грунтах // Глобальные климатические процессы и их влияние на экосистемы арктических и субарктических регионов: Тез. докл. Междунар. науч. конф. (г. Мурманск, 9-11 ноября 2011 г.). - Апатиты: Изд-во КНЦ РАН, 2011. - С. 19-20.

378. Гарбуль Е.А., Моисеев Д.В. Усовершенствованный стол для разбора проб макрозообентоса // Арктическое морское природопользование в XXI веке - современный баланс научных традиций и инноваций (к 80-летию ММБИ КНЦ РАН): Тез. докл. Междунар. науч. конф. (г. Мурманск, 1-3 апреля 2015 г.). - Апатиты: Изд-во КНЦ РАН, 2015. - C. 35-36.

379. Гаргопа Ю.М., Сарвилина С.В. Климатические изменения зообентоса Азовского моря в условиях антропогенных воздействий // Водные ресурсы. - 2011. - Т. 38, № 6. - С. 698-706.

380. Головкина Е.M., Набоженко М.В. Современное состояние донных сообществ Керченского пролива (российский сектор) и заливов Таманского полуострова // Вестн. Южного науч. центра РАН. - 2012. T. 8, № 2. - C. 53-61.

381. Гудимов A.B. Сравнительные исследования экологии и функциональной активности морских организмов разных экосистем (на примере мидий Черного и Баренцева морей) // Комплексные исследования больших морских экосистем России. - Апатиты: Изд-во КНЦ РАН, 2011. - С. 428-464.

382. Гудимов A.B., Свитина В.C. Балянусы (Semibalanus balanoides) как биологические индикаторы ранних глобальных изменений условий среды в Арктике // Глобальные климатические процессы и их влияние на экосистемы арктических и субарктических регионов: Тез. докл. Междунар. науч. конф. (г. Мурманск, 9-11 ноября 2011 г.). - Апатиты: Изд-во КНЦ РАН, 2011. - С. 27. 
383. Гудимов А.В., Свитина В.С. Литоральные раки-балянусы Semibalanus balanoides (L.) в градиенте факторов среды эстуарной зоны Кольского залива // Геодинамика и экология Баренц-региона в XXI веке: Матер. конф. с междунар. участием (15-18 сентября 2014 г., Архангельск). - Архангельск: Изд. Ин-та экол. проблем Севера УрО PAH, 2014. - C. 51-53.

384. Губки центральной и южной частей Карского моря / Г.С. Морозов, О.С. Любина, А.В. Голиков, Р.М. Сабиров // Функционирование и динамика водных экосистем в условиях климатических изменений и антропогенных воздействий: Матер. 5-й Междунар. конф., посвященной памяти выдающегося гидробиолога Г.Г. Винберга (12-17 октября 2015 г., г. Санкт-Петербург, Россия). СПб.: Лема, 2015. - С. 173-174.

385. Дворецкий А.Г. Биологические особенности симбиотических амфипод, заселяющих камчатского краба в губе Сайда Кольского залива (Баренцево море) // Изучение и освоение морских и наземных экосистем в условиях арктического и аридного климата: Матер. Междунар. науч. конф. (6-11 июня 2011 г., Ростов-на-Дону). - Ростов н/Д.: Изд-во ЮНЦ РАН, 2011. - С. 261-264.

386. Двореикий А.Г. Биологические особенности эпибионтов камчатского краба в губе Долгая // Глобальные климатические процессы и их влияние на экосистемы арктических и субарктических регионов: Тез. докл. Междунар. науч. конф. (г. Мурманск, 9-11 ноября 2011 г.). Апатиты: Изд-во КНЦ РАН, 2011. С. 31-33.

387. Двореикий А.Г. Оценка симбиотических отношений бокоплавов Ischyrocerus при поселении на икре камчатского краба Баренцева моря // Материалы XXIX конференции молодых ученых Мурманского морского биологического института, посвященной 140-летию со дня рождения Г.А. Клюге, «Морские исследования экосистем европейской Арктики» (г. Мурманск, май 2011 г.). - Мурманск: Изд. ММБИ КНЦ PAH, 2011. - C. 57-61.

388. Двореикий А.Г. Некоторые особенности биологии камчатского краба в губе Дальнезеленецкая в летний период 2009 г. // Материалы Всероссийской конференции молодых ученых и специалистов с международным участием, посвященной 90-летию со дня постройки первого научно-исследовательского судна ПИНРО «Персей». Мурманск: Изд-во ПИНРО, 2012. - С. 75-79.

389. Дворецкий А.Г. Сообщество обрастателей камчатского краба в губе Дальнезеленецкая в летний период 2009 г. // Материалы XXX юбилейной конференции молодых ученых Мурманского морского биологического института, посвященной 150 -летию со дня рождения 
Н.М. Книповича, «Проблемы океанографии, биологии и освоения биоресурсов морей российской Арктики» (г. Мурманск, май 2012). Мурманск: Изд. ММБИ КНЦ РАН, 2012. - С. 42-49.

390. Двореикий А.Г. Вселение камчатского краба в Баренцево море и его воздействие на экосистему (обзор). 1. Выедание бентоса // Вопросы рыболовства. - 2012. - Т. 13, № 1(49). - С. 18-34.

391. Дворецкий А.Г. Вселение камчатского краба в Баренцево море и его воздействие на экосистему (обзор). 2. Конкуренция с местными видами // Вопросы рыболовства. - 2013. - Т. 14, № 1(53). C. $16-25$.

392. Дворецкий А.Г. Вселение камчатского краба в Баренцево море и его воздействие на экосистему (обзор). 3. Ассоциированные организмы // Вопросы рыболовства. - 2013. - Т. 14, № 3(55). - С. 1-15.

393. Дворецкий А.Г. Исследования камчатского краба в прибрежье Баренцева моря // Тр. Кольского науч. центра РАН. - 2013. - Т. 1(14). Сер. Океанология. - Вып. 1. - С. 183-207.

394. Двореикий А.Г., Дворецкий В.Г. Рост молоди камчатского краба в двух губах Восточного Мурмана (Баренцево море) // Изв. ТИНРО. - 2011. - Т. 164. - С. 185-195.

395. Двореикий А.Г., Дворецฺкий В.Г. Межвидовая конкуренция симбионтов и обрастателей камчатского краба в Баренцевом море // Докл. РАН. - 2011. - Т. 440, № 3. - С. 417-419.

396. Дворецкий А.Г., Дворецкий В.Г. Новые данные о симбиозе амфипод Ischyrocerus и камчатского краба при поселении бокоплавов на икре хозяина // Докл. РАН. - 2012. - Т. 445, № 3. - С. 360-362.

397. Двореикий А.Г., Двореикий В.Г. Особенности биологии бокоплава Ischyrocerus commensalis, симбионта камчатского краба в губе Сайда (Баренцево море) // Вестн. Кольского науч. центра РАН. 2012. - № 2(9). - С. 23-29.

398. Двореикий А.Г., Двореикий В.Г. Сравнительный анализ сообществ обрастателей камчатского краба во фьордах Баренцева моря // Изв. ТИНРО. - 2012. - Т. 169. - С. 100-109.

399. Двореикий А.Г., Дворецкий В.Г. Эпифауна крабов-литодид в Баренцевом море. - Апатиты: Изд-во КНЦ РАН, 2012. - 410 с.

400. Дворецкий А.Г., Дворецкий В.Г. Видовой состав макросимбионтов и обрастателей камчатского краба в прибрежье Баренцева моря (губа Дальнезеленецкая) в 2010 году // Вестн. Мурм. гос. техн. ун-та. - 2013. - Т. 16, № 3. - С. 452-459. 
401. Двореикий А.Г., Двореикий В.Г. Некоторые черты биологии камчатского краба в губе Дальнезеленецкая (Баренцево море) в летний период // Рыбное хозяйство. - 2013. - № 5. - С. 79-84.

402. Дворецкий А.Г., Двореикий В.Г. Сообщество обрастателей камчатского краба в губе Дальнезеленецкая (Восточный Мурман, Баренцево море): сравнительный анализ сезонных особенностей // Тр. Карельского науч. центра РАН. - 2013. - Сер. Биогеогр. - Вып. 14, № 2 . - C. 78-85.

403. Дворецкий А.Г., Двореияий В.Г. Особенности роста молоди камчатского краба в губе Дальнезеленецкая // Материалы XXXI конференции молодых ученых Мурманского морского биологического института, посвященной 135-летию со дня рождения К.М. Дерюгина, «Океанография и биология арктических морей» (г. Мурманск, май 2013). - Мурманск: Изд. ММБИ КНЦ РАН, 2013. - С. 45-49.

404. Дворецкий А.Г., Дворецкий В.Г. Влияние климатических факторов на молодь камчатского краба в прибрежье Баренцева моря // Вопросы рыболовства. - 2014. - Т. 15, № 4. - С. 434-442.

405. Двореикий А.Г., Двореикий В.Г. Влияние гидродинамического режима акватории на сообщества обрастателей камчатского краба в Баренцевом море // Океанология. - 2014. - Т. 54, № 2. - С.193-199.

406. Двореикий А.Г., Дворецкий В.Г. Влияние повреждений экзоскелета на линьку камчатского краба Баренцева моря // Экологоэволюционные исследования морских организмов и экосистем: Матер. XIV Междунар. науч. конф. студентов и аспирантов «Проблемы Арктического региона» (г. Мурманск, май 2014 г.). Т. І. Форум молодых ученых, посвященный 110 -летию со дня рождения Ю.И. Полянского (XXXII конференция молодых ученых ММБИ). Мурманск: Изд. ММБИ КНЦ РАН, 2014. - С. 49-54.

407. Дворецкий А.Г., Дворецкий В.Г. Исследования биологии камчатского краба в прибрежье Восточного Мурмана Баренцева моря // Современные проблемы экологии и природопользования: Матер. регион. науч.-практ. конф., посвященной 15-летию со дня основания кафедры биоэкологии, Мурманск, 27-28 февраля 2014 г. - Мурманск: Изд-во Мурм. гос. техн. ун-та, 2014. - С. 60-64.

408. Дворецкий А.Г., Дворечкий В.Г. Камчатский краб в прибрежье Мурмана. Популяционная динамика // Морские экосистемы и сообщества в условиях современных климатических изменений. - СПб.: Реноме, 2014. - C. 148-164.

409. Дворечкий А.Г., Дворечкий В.Г. Камчатский краб в прибрежье Мурмана. Симбионты // Морские экосистемы и сообщества в условиях современных климатических изменений. - СПб.: Реноме, 2014. C. $164-176$. 
410. Двореикий А.Г., Дворецкий В.Г. Особенности биологии камчатского краба в прибрежье Баренцева моря в летний период // Вестн. СПбГУ. - 2014. - Сер. 3. - Вып. 1. - С. 5-13.

411. Двореикий А.Г., Двореикий В.Г. Особенности пищевого поведения симбиотических амфипод, обитающих на камчатском крабе Баренцева моря // Вестн. Южного науч. центра РАН. - 2014. - Т. 10, № 2. - C. 52-58.

412. Двореикий А.Г., Двореикий В.Г. Вариации размеров созревания самок камчатского краба в прибрежье Баренцева моря // Арктическое морское природопользование в XXI веке - современный баланс научных традиций и инноваций (к 80-летию ММБИ КНЦ РАН): Тез. докл. Междунар. науч. конф. (г. Мурманск, 1-3 апреля 2015 г.). Апатиты: Изд-во КНЦ РАН, 2015. - С. 47-48.

413. Дворещкий А.Г., Дворецкий В.Г. Влияние микроповреждений экзоскелета на линьку молоди камчатского краба Баренцева моря // Изв. ТИНРО. - 2015. - Т. 181. - С. 209-215.

414. Дикаева Д.Р. Сообщества полихет в заливе Белльсунн (Западный Шпицберген) // Материалы XXIX конференции молодыХ ученых Мурманского морского биологического института, посвященной 140 -летию со дня рождения Г.А. Клюге, «Морские исследования экосистем европейской Арктики» (г. Мурманск, май 2011 г.). Мурманск: Изд. ММБИ КНЦ РАН, 2011. С. 65-71.

415. Дикаева Д.Р. Современное распределение сообществ полихет в губах Восточного Мурмана (губы Дроздовка и Ивановская) // Материалы XXX юбилейной конференции молодых ученых Мурманского морского биологического института, посвященной 150-летию со дня рождения Н.М. Книповича, «Проблемы океанографии, биологии и освоения биоресурсов морей российской Арктики» (г. Мурманск, май 2012). - Мурманск: Изд. ММБИ КНЦ РАН, 2012. - С. 57-61.

416. Дикаева Д.Р. Распределение литоральных сообществ полихет в куту Кольского залива (эстуарий реки Тулома) // 2013 год год охраны окружающей среды в России: Тез. докл. конф. молодых ученых (Мурманск, 12-13 февраля 2013 г.). - Мурманск: Изд-во Мурм. гос. техн. ун-та, 2013. - С. 81-84.

417. Дикаева Д.Р. Состав и количественное распределение сообществ полихет во фьордах и заливах Западного Шпицбергена // Материалы XXXI конференции молодых ученых Мурманского морского биологического института, посвященной 135-летию со дня рождения К.М. Дерюгина, «Океанография и биология арктических морей» (г. Мурманск, май 2013). - Мурманск: Изд. ММБИ КНЦ РАН, 2013. C. 56-61. 
418. Дикаева Д.Р. Особенности распределения литоральных сообществ полихет в эстуарии Кольского залива // Эколого-эволюционные исследования морских организмов и экосистем: Матер. XIV Междунар. науч. конф. студентов и аспирантов «Проблемы Арктического региона» (г. Мурманск, май 2014 г.). Т. І. Форум молодых ученых, посвященный 110-летию со дня рождения Ю.И. Полянского (XXXII конференция молодых ученых ММБИ). - Мурманск: Изд. ММБИ КНЦ РАН, 2014. - С. 63-67.

419. Дикаева Д.Р., Фролова Е.А. Изменение видового состава сообществ полихет на разрезе «Кольский меридиан» (Баренцево море) в период климатических изменений // Изучение и освоение морских и наземных экосистем в условиях арктического и аридного климата: Матер. Междунар. науч. конф. (6-11 июня 2011 г., Ростов-на-Дону). Ростов н/Д.: Изд-во ЮНЦ РАН, 2011. - С. 155-158.

420. Дикаева Д.Р., Фролова Е.А. Количественное распределение сообществ полихет в районе архипелага Новая Земля // Глобальные климатические процессы и их влияние на экосистемы арктических и субарктических регионов: Тез. докл. Междунар. науч. конф. (г. Мурманск, 9-11 ноября 2011 г.). - Апатиты: Изд-во КНЦ РАН, 2011. - C. 51-53.

421. Дикаева Д.Р., Фролова Е.А. Современное распределение сообществ полихет во фьордах Западного Шпицбергена // Вестн. Мурм. гос. техн. ун-та. 2014. Т. 17, № 1. С. 119-127.

422. Дикаева Д.Р., Фролова Е.А. Сообщества полихет губ Дроздовка и Ивановская Восточного Мурмана // Современные проблемы экологии и природопользования: Матер. регион. науч.-практ. конф., посвященной 15-летию со дня основания кафедры биоэкологии, Мурманск, 27-28 февраля 2014 г. - Мурманск: Изд-во Мурм. гос. техн. ун-та, 2014. - С. 201-206.

423. Дикаева Д.Р., Фролова Е.А. Сообщества полихет фьордов Западного Шпицбергена // Комплексные исследования природы Шпицбергена и прилегающего шельфа: Матер. Междунар. науч. конф. (Мурманск, 6-8 ноября 2014 г.). Вып. 12. - М.: ГЕОС, 2014. - С. 72-76.

424. Дикаева Д.Р., Фролова Е.А. Многолетнее распределение сообществ полихет на разрезе «Кольский меридиан» // Арктическое морское природопользование в XXI веке - современный баланс научных традиций и инноваций (к 80-летию ММБИ КНЦ РАН): Тез. докл. Междунар. науч. конф. (г. Мурманск, 1-3 апреля 2015 г.). Апатиты: Изд-во КНЦ РАН, 2015. - С. 57-59. 
425. Донные сообщества у берегов арктических архипелагов / Е.А. Фролова, О.С. Любина, О.Л. Зимина, Д.Р. Дикаева, А.А. Фролов, О.Ю. Ахметчина, Е.А. Гарбуль, И.О. Нехаев // Наземные и морские экосистемы. - М.; СПб.: Paulsen, 2011. - С. 181-210.

426. Зензеров В.С., Илющенко А.М., Типисова Е.В. Камчатский краб в прибрежье Мурмана. Морфофизиология и новые представления о роли камчатского краба в экосистеме Баренцева моря // Морские экосистемы и сообщества в условиях современных климатических изменений. - СПб.: Реноме, 2014. - С. 198-204.

427. Зимина О.Л. Фауна и особенности распределения донных ракообразных (Crustacea: Peracarida) в прибрежной зоне Кольского полуострова // Материалы XXIX конференции молодых ученых Мурманского морского биологического института, посвященной 140летию со дня рождения Г.А. Клюге, «Морские исследования экосистем европейской Арктики» (г. Мурманск, май 2011 г.). - Мурманск: Изд. ММБИ КНЦ РАН, 2011. - С. 80-85.

428. Зимина О.Л. Особенности биогеографической структуры фауны донных ракообразных (Crustacea: Peracarida) в прибрежной зоне Кольского полуострова и прилежащей акватории // Материалы XXX юбилейной конференции молодых ученых Мурманского морского биологического института, посвященной 150-летию со дня рождения Н.M. Книповича, «Проблемы океанографии, биологии и освоения биоресурсов морей российской Арктики» (г. Мурманск, май 2012). Мурманск: Изд. ММБИ КНЦ РАН, 2012. - С. 67-72.

429. Зимина О.Л. Находка краба стригуна Chionoecetes opilio (O. Fabricius, 1788) (Decapoda: Majidae) в Карском море // Биология моря. - 2014. - Т. 40, № 6. - C. 497-499.

430. Зимина О.Л., Любина О.С. Особенности распределения перакарид (Crustacea: Malacosrtraca) в прибрежной зоне Кольского полуострова и прилежащей акватории // Современные проблемы экологии и природопользования: Матер. регион. науч.-практ. конф., посвященной 15-летию со дня основания кафедры биоэкологии, Мурманск, 27-28 февраля 2014 г. - Мурманск: Изд-во Мурм. гос. техн. ун-та, 2014. - С. 101-107.

431. Зимина О.Л., Любина О.С. Фауна Peracarida (Crustacea: Malacostraca) на разрезе «Кольский меридиан» // Арктическое морское природопользование в XXI веке - современный баланс научных традиций и инноваций (к 80-летию ММБИ КНЦ РАН): Тез. докл. Междунар. науч. конф. (г. Мурманск, 1-3 апреля 2015 г.). - Апатиты: Изд-во КНЦ РАН, 2015. - С. 80-81. 
432. Зимина О.Л., Семин В.Л. Новые данные о фауне беспозвоночных Карского и Печорского морей по результатам траловой съемки 2012 г. // Материалы XXXI конференции молодых ученых Мурманского морского биологического института, посвященной 135летию со дня рождения К.М. Дерюгина, «Океанография и биология арктических морей» (г. Мурманск, май 2013). - Мурманск: Изд. ММБИ КНЦ РАН, 2013. - С. 90-96.

433. Зимина О.Л., Семин В.Л. Особенности фауны донных беспозвоночных арктических морей (Карское, Лаптевых, ВосточноСибирское) по результатам траловых съемок 2012-2014 гг. // Экосистема Карского моря - новые данные экспедиционных исследований: Матер. науч. конф. - М.: АПР, 2015. - С. 184-188.

434. Зообентос сублиторали губ Кольского полуострова / О.С. Любина, О.Л. Зимина, Е.А. Фролова, А.А. Фролов, О.Ю. Ахметчина, И.О. Нехаев, Д.Р. Дикаева, Е.А. Гарбуль // Морские экосистемы и сообщества в условиях современных климатических изменений. СПб.: Реноме, 2014. - С. 131-148.

435. Зуев Ю.А., Павлова Л.В. Особенности распределения мегабентоса в верхней сублиторали Кольского залива (Баренцево море) // Докл. РАН. - 2011. - Т. 439, № 5. - С. 713-717.

436. Зуев Ю.А., Павлова Л.В. Экологические особенности зоны влияния маргинального фильтра в Кольском заливе Баренцева моря // Потенциал современной географии в решении проблем развития регионов: Матер. Междунар. науч.-практ. конф. молодых ученых, посвященной 95-летию Национальной академии наук Украины, Украина, г. Киев, 3-5 октября 2013 г. - Київ: Логос, 2013. - С. 208-212.

437. Зуев Ю.А., Павлова Л.В. Мегабентос верхней сублиторали Кольского залива Баренцева моря [Электронный ресурс] // XI съезд Гидробиологического общества при Российской академии наук: Тез. докл., Красноярск, 22-26 сент. 2014 г. - Электрон. текст. дан. Красноярск: Изд-во Сибирского фед. ун-та, 2014. - С. 67-68. - Систем. требования: PC не ниже класса Pentium I; $128 \mathrm{Mb}$ RAM; Windows 98/XP/7; Adobe Reader V8.0 и выше. - Загл. с экрана.

438. Зуев Ю.А., Павлова Л.В. Влияние климатических колебаний и антропогенного воздействия на мегабентос Кольского залива // Функционирование и динамика водных экосистем в условиях климатических изменений и антропогенных воздействий: Матер. 5-й Междунар. конф., посвященной памяти выдающегося гидробиолога Г.Г. Винберга (12-17 октября 2015 г., г. Санкт-Петербург, Россия). СПб.: Лема, 2015. - С. 323-324. 
439. Илющенко А.М. Новые данные об устойчивости камчатского краба Баренцева моря к низкой солености // Материалы XXIX конференции молодых ученых Мурманского морского биологического института, посвященной 140 -летию со дня рождения Г.А. Клюге, «Морские исследования экосистем европейской Арктики» (г. Мурманск, май 2011 г.). - Мурманск: Изд. ММБИ КНЦ РАН, 2011. - С. 93-94.

440. Илющенко А.М., Зензеров В.С. Новые данные по устойчивости камчатского краба Баренцева моря к низкой солености // Экология. 2012. - № 2. - C. 159-160.

441. Любина O.C. Влияние изменений условий среды на распределение зообентоса на разрезе «Кольский меридиан» в Баренцевом море // Глобальные климатические процессы и их влияние на экосистемы арктических и субарктических регионов: Тез. докл. Междунар. науч. конф. (г. Мурманск, 9-11 ноября 2011 г.). Апатиты: Изд-во КНЦ РАН, 2011. - С. 113-116.

442. Любина O.C. Морфология и распространение амфипод Ericthonius stephenseni и Guernea nordenskjoldi (Crustacea) в Баренцевом и Карском морях // Зоол. журн. - 2011. - Т. 90, № 3. - С. 285-292.

443. Любина О.С. Особенности распределения амфипод (Crustacea, Amphipoda) в южной части Баренцева моря // Современные проблемы экологии и природопользования: Матер. регион. науч.практ. конф., посвященной 15-летию со дня основания кафедры биоэкологии, Мурманск, 27-28 февраля 2014 г. - Мурманск: Изд-во Мурм. гос. техн. ун-та, 2014. - С. 97-101.

444. Любина О.С., Фролов А.А. Современные исследования зообентоса Баренцева моря и сопредельных вод // Вестн. Кольского науч. центра РАН. - 2015. - № 2(21). - С. 20-24.

445. Любина О.С., Анисимова Н.А., Любин П.А. Изменения зообентоса на разрезе «Кольский меридиан» с 1995 по 2012 гг. // Арктическое морское природопользование в XXI веке - современный баланс научных традиций и инноваций (к 80-летию ММБИ КНЦ РАН): Тез. докл. Междунар. науч. конф. (г. Мурманск, 1-3 апреля 2015 г.). Апатиты: Изд-во КНЦ РАН, 2015. - С. 140-142.

446. Любина О.С., Брязгин В.Ф., Разновская С.В. Состав и распределение бентосных амфипод (Crustacea, Amphipoda) в южной части Баренцева моря // Биология моря. - 2014. - Т. 40, № 4. - С. 257-267.

447. Любина О.С., Зимина О.Л., Анисимова Н.А. Распределение и изменчивость фауны амфипод (Crustacea, Amphipoda) на Кольском разрезе (Баренцево море) // Докл. РАН. - 2012. - Т. 442, № 3. - С. 426-429. 
448. Малавенда С.В., Шавылин А.А. Макрофитобентос Кольского залива Баренцева моря: современное состояние и уязвимость от нефтяных разливов // Pontus Euxinus 2015: Тез. IX Bсерос. науч.-практ. конф. молодых ученых (с международным участием) по проблемам водных экосистем, посвященной 100-летию со дня рождения д.б.н., проф., чл.-корр. АН УССР В.Н. Грёзе (17-20 ноября 2015 г.). Севастополь: DigitPrint, 2015. - С. 103-104.

449. Малавенда С.В., Малавенда С.С., Комракова Д.Г. Особенности макрофитобентоса Кольского залива [Электронный ресурс] // Наука и образование - 2014: Матер. Междунар. науч.-техн. конф., Мурманск, 24-28 марта 2014 г. - Электрон. текст. дан. - Мурманск: Изд-во Мурм. гос. техн. ун-та, 2014. - C. 242-245. - 1 электрон. опт. диск (CD-ROM). Систем. требования: РС не ниже класса Pentium II; 128 Mb PAM; свободное место на HDD $100 \mathrm{Mb}$; Adobe Acrobat Reader; дисковод CD-ROM 2-х и выше. - Загл. с экрана. - Электрон. текст подг. ФГБОУ ВПО «МГТУ». - № гос. регистрации 0321401155.

450. Материалы к современному состоянию макрозообентоса Цимлянского водохранилища / И.В. Шохин, Н.И. Булышева, E.M. Головкина, М.В. Набоженко // Цимлянское водохранилище: состояние водных и прибрежных экосистем, проблемы и пути решения. - Ростов н/Д.: Изд-во ЮНЦ РАН, 2011. - С. 42-45.

451. Набоженко M.В. Современное распределение двустворчатых моллюсков (Mollusca: Bivalvia) северо-восточной части Черного моря // Вестн. Южного науч. центра РАН. - 2011. - Т. 7, № 3. - С. 79-86.

452. Набоженко M.В. Реконструкция и динамика таксоценоза двустворчатых моллюсков (Mollusca: Bivalvia) Азовского моря в позднем голоцене в связи с изменением солености // Тр. Зоол. ин-та РАН. - 2013. - Т. 317 (Прил. 3. Пятьдесят лет концепции критической солености). - С. 182-191.

453. Набоженко М.В., Коваленко Е.П. Современное распределение донных сообществ макрозообентоса в Ейском лимане (Таганрогский залив Азовского моря) // Океанология. - 2011. - Т. 51, № 4. - С. 669-674.

454. Набоженко М.В., Сон М.О. Особенности распределения Dreissena bugensis (Andrusov, 1897) (Mollusca: Bivalvia: Dreissenidae) в низовьях Дона, Волги и Таганрогском заливе Азовского моря // Азовское море, Керченский пролив и предпроливные зоны в Черном море: проблемы управления прибрежными территориями для обеспечения экологической безопасности и рационального природопользования. Ростов н/Д.: Изд-во ЮНЦ РАН, 2012. - С. 191-197.

455. Набоженко М.В., Шохин И.В., Булышева Н.И. Донная фауна прикаспийских ильменей // Биологическое разнообразие Кавказа: Матер. XII Междунар. конф. (Махачкала, 4-7 ноября 2010). - Махачкала: Изд-во Дагест. гос. ун-та, 2010. - С. 390-391. 
456. Нехаев И.О. Особенности географического распространения подродов и жизненных форм Lymnaeidae (Gastropoda, Pulmonata) в Восточной Европе // Изв. РАН. Сер. Биол. - 2011. - № 4. - С. 477-483.

457. Нехаев И.О. Особенности формирования состава морфологических групп прудовиков в Арктике (Gastropoda: Pulmonata: Lymnaeidae) // Материалы XXIX конференции молодых ученыX Мурманского морского биологического института, посвященной 140летию со дня рождения Г.А. Клюге, «Морские исследования экосистем европейской Арктики» (г. Мурманск, май 2011 г.). - Мурманск: Изд. ММБИ КНЦ РАН, 2011. - С. 162-166.

458. Нехаев И.О. Предварительный анализ таксономической структуры фауны раковинных брюхоногих моллюсков в прибрежной части Кольского полуострова // Материалы XXX юбилейной конференции молодых ученых Мурманского морского биологического института, посвященной 150 -летию со дня рождения Н.М. Книповича, «Проблемы океанографии, биологии и освоения биоресурсов морей российской Арктики» (г. Мурманск, май 2012). - Мурманск: Изд. ММБИ КНЦ РАН, 2012. - С. 137-140.

459. Нехаев И.О. Раковинные брюхоногие моллюски залива Грёнфьорд // Комплексные исследования природы Шпицбергена: Матер. Междунар. науч. конф. (Мурманск, 1-3 ноября 2012 г.). Вып. 11. - М.: ГЕОС, 2012. - C. 277-279.

460. Нехаев И.О. Сравнение видовых описаний пресноводных Gastropoda в работах двух систематических школ // Наукові записки Тернопільського національного університету імені Володимира Гнатюка. - 2012. - Серія: Біологія, 2. - Спец. випуск «Молюски: результати, проблеми і перспективи досліджень». - С. 24-32.

461. Нехаев И.О. Таксономическая и зоогеографическая структура фауны раковинных брюхоногих моллюсков в прибрежной части Кольского полуострова // Биоресурсы и аквакультура: Тез. докл. Школы молодых ученых по морской биологии (Мурманск, 28-29 февраля 2012 г.). - Мурманск: Изд-во Мурм. гос. техн. ун-та, 2012. - С. 33-36.

462. Нехаев И.О. О возможных причинах новых находок брюхоногих моллюсков в Баренцевом море // Материалы XXXI конференции молодых ученых Мурманского морского биологического института, посвященной 135-летию со дня рождения К.М. Дерюгина, «Океанография и биология арктических морей» (г. Мурманск, май 2013). - Мурманск: Изд. ММБИ КНЦ РАН, 2013. - С. 144-147.

463. Нехаев И.О. О возможных изменениях в распространении некоторых видов брюхоногих моллюсков в водах Мурмана // Экологоэволюционные исследования морских организмов и экосистем: Матер. 
XIV Междунар. науч. конф. студентов и аспирантов «Проблемы Арктического региона» (г. Мурманск, май 2014 г.). Т. І. Форум молодых ученых, посвященный 110 -летию со дня рождения Ю.И. Полянского (XXXII конференция молодых ученых ММБИ). Мурманск: Изд. ММБИ КНЦ РАН, 2014. - С. 126-129.

464. Нехаев И.О. Отражают ли новые находки моллюсков на югозападе Баренцева моря происходящие климатические изменения? // Арктическое морское природопользование в XXI веке - современный баланс научных традиций и инноваций (к 80-летию ММБИ КНЦ РАН): Тез. докл. Междунар. науч. конф. (г. Мурманск, 1-3 апреля 2015 г.). Апатиты: Изд-во КНЦ РАН, 2015. - С. 176-178.

465. Новые данные о макрозообентосе Бейсугского лимана Азовского моря / Н.И. Бульшщева, М.В. Набоженко, В.Л. Сёмин, И.В. Шохин, A.К. Залота // Юг России: экология, развитие. - 2013. - № 3. - С. 53-60.

466. Особенности распределения бентосных сообществ во фьордах Западного Шпицбергена / О.С. Любина, О.Л. Зимина, Е.А. Фролова, П.А. Любин, А.А. Фролов, Д.Р. Дикаева, О.Ю. Ахметчина, Е.А. Гарбуль // Проблемы Арктики и Антарктики. - 2011. - № 1(87). - С. 28-40.

467. Особенности распределения зообентоса в прибрежной зоне Кольского полуострова / О.С. Любина, О.Л. Зимина, Е.А. Фролова, А.А. Фролов, И.О. Нехаев, Д.Р. Дикаева // Вестн. Мурм. гос. техн. ун-та. 2012. - T. 15, № 4. - С. 776-785.

468. Павлова Л.В. Выедание бентоса камчатским крабом в прибрежье Баренцева моря // Глобальные климатические процессы и их влияние на экосистемы арктических и субарктических регионов: Тез. докл. Междунар. науч. конф. (г. Мурманск, 9-11 ноября 2011 г.). Апатиты: Изд-во КНЦ РАН, 2011. - С. 144-146.

469. Павлова Л.В. Исследование влияния молоди камчатского краба на донные сообщества Баренцева моря // Комплексные исследования больших морских экосистем России. - Апатиты: Изд-во КНЦ РАН, 2011. - С. 234-258.

470. Павлова Л.В. Камчатский краб в прибрежье Мурмана. Питание // Морские экосистемы и сообщества в условиях современных климатических изменений. - СПб.: Реноме, 2014. - С. 177-197.

471. Павлова Л.В. Величина и структура экологического рациона камчатского краба как критерии оценки влияния вселенца на бентос Баренцева моря // Арктическое морское природопользование в XXI веке - современный баланс научных традиций и инноваций (к 80-летию ММБИ КНЦ РАН): Тез. докл. Междунар. науч. конф. (г. Мурманск, 1-3 апреля 2015 г.). - Апатиты: Изд-во КНЦ РАН, 2015. - С. 183-185. 
472. Павлова Л.В. Экологический рацион камчатского краба в прибрежной мелководной зоне Баренцева моря // Докл. РАН. - 2015. T. 463, № 2. - С. 244-249.

473. Пантелеева Н.Н. К биоразнообразию экосистем: новые виды беспозвоночных в фауне залива Грён-фьорд (Западный Шпицберген) // Изучение и освоение морских и наземных экосистем в условиях арктического и аридного климата: Матер. Междунар. науч. конф. (6-11 июня 2011 г., Ростов-на-Дону). - Ростов н/Д.: Изд-во ЮНЦ РАН, 2011. - C. 308-311.

474. Пантелеева Н.Н. Беспозвоночные обитатели залива Грёнфьорд // Рус. вестн. Шпицбергена. - 2013. - № 7. - С. 26-27.

475. Пантелеева Н.Н. Гидроиды литорали Восточного Мурмана (Баренцево море) и их сезонное развитие // Морская биология, геология, океанология - междисциплинарные исследования на морских стационарах: Матер. науч. конф., посвященной 75-летию Беломорской биологической станции им. Н.А. Перцова (г. Москва, 27 февраля1 марта 2013). - М.: Тов-во науч. изд. КМК, 2013. - С. 227-232.

476. Пантелеева Н.Н. Исследование книдарий в ММБИ: история и современность // Арктическое морское природопользование в XXI веке - современный баланс научных традиций и инноваций (к 80-летию ММБИ КНЦ РАН): Тез. докл. Междунар. науч. конф. (г. Мурманск, 1-3 апреля 2015 г.). - Апатиты: Изд-во КНЦ РАН, 2015. - С. 189-190.

477. Пантелеева Н.Н., Зимина О.Л. Новые данные о медузах (Cnidaria) в районе архипелага Шпицберген // Комплексные исследования природы Шпицбергена и прилегающего шельфа: Матер. Междунар. науч. конф. (Мурманск, 6-8 ноября 2014 г.). Вып. 12. - М.: ГЕОС, 2014. - C. 237-242.

478. Предварительные результаты современного мониторинга зообентоса на разрезе «Кольский меридиан» (Баренцево море) / О.С. Любина, Е.А. Фролова, Д.Р. Дикаева, Н.А. Анисимова, П.А. Любин, А.А. Фролов, Е.А. Гарбуль, О.Л. Зимина, О.Ю. Ахметчина, И.О. Нехаев // Тр. Кольского науч. центра РАН. - 2013. - Т. 1(14). - Сер. Океанология. Вып. 1. - С. 208-223.

479. Распределение зообентоса в губах Ивановская и Дроздовка Восточного Мурмана (Баренцево море) / О.С. Любина, О.Л. Зимина, Е.А. Фролова, А.А. Фролов, Д.Р. Дикаева, Н.Н. Пантелеева, И.О. Нехаев, Е.А. Гарбуль // Докл. РАН. - 2012. - Т. 447, № 2. - С. 230-234.

480. Распределение ракообразных (Crustacea) в западной части Баренцева моря по данным траловых съемок в 2011 году / О.С. Любина, О.Л. Зимина, П.А. Любин, Л.Л. Йоргенсен // Комплексные исследования природы Шпицбергена: Матер. Междунар. науч. конф. (Мурманск, 1-3 ноября 2012 г.). Вып. 11. - М.: ГЕОС, 2012. - С. 154-159. 
481. Савикин А.И. Изменение фауны двустворчатых моллюсков (Mollusca: Bivalvia) Таганрогского залива за последние сто лет // Экологическая безопасность приморских регионов (порты, берегозащита, рекреация, марикультура): Матер. Междунар. науч. конф., посвященной 150-летию Н.М. Книповича (Ростов-на-Дону, 5-8 июня 2012 г.). Ростов н/Д.: Изд-во ЮНЦ РАН, 2012. - С. 206-208.

482. Свитина B.C., Гудимов A.B. Усоногие раки Semibalanus balanoides (L.) в градиенте факторов среды эстуарной литорали кута Кольского залива // Современные проблемы экологии и природопользования: Матер. регион. науч.-практ. конф., посвященной 15-летию со дня основания кафедры биоэкологии, Мурманск, 27-28 февраля 2014 г. - Мурманск: Изд-во Мурм. гос. техн. ун-та, 2014. - С. 216-221.

483. Свитина В.С., Гудимов А.В. Особенности распределения и экология усоногих раков Semibalanus balanoides на некоторых участках эстуарной литорали Кольского залива и Ура-губы // Современные эколого-биологические и химические исследования, техника и технология производств: Матер. Междунар. науч.-практ. конф., Мурманск, 7 апреля 2015 г.: В 2-х ч. - Мурманск: Изд-во Мурм. гос. техн. ун-та, 2015. - Ч. 1. - С. 271-276.

484. Свитина B.С., Гудимов А.В. Популяция усоногих раков Semibalanus balanoides: условия выживания на эстуарной литорали кута Кольского залива // Арктическое морское природопользование в XXI веке - современный баланс научных традиций и инноваций (к 80-летию ММБИ КНЦ РАН): Тез. докл. Междунар. науч. конф. (г. Мурманск, 1-3 апреля 2015 г.). - Апатиты: Изд-во КНЦ РАН, 2015. - C. 212-213.

485. Свитина В.С., Гудимов А.В. Экологические исследования популяции усоногих раков Semibalanus balanoides (L.) (Crustacea) в южном колене Кольского залива (эстуарий р. Тулома) // Биоразнообразие наземных и водных животных. Зооресурсы: Сб. тр. III Всерос. науч. интернет-конф. с междунар. участием. - Казань: ИП Синяев Д.Н., 2015. - С. 53-57.

486. Семин В.Л. Экология полихет Азовского моря и лиманов российской части его побережья: Автореф. дис. ... канд. биол. наук (25.00.28 - океанология). - Мурманск, 2011. - 25 с.

487. Семин В.Л., Зимина О.Л. Предварительные данные о мегабентосе моря Лаптевых и западной части Восточно-Сибирского моря // Арктическое морское природопользование в XXI веке - современный баланс научных традиций и инноваций (к 80-летию ММБИ КНЦ РАН): Тез. докл. Междунар. науч. конф. (г. Мурманск, 1-3 апреля 2015 г.). Апатиты: Изд-во КНЦ РАН, 2015. - С. 218-220. 
488. Симбионты промысловых видов крабов Охотского и Баренцева морей / Г.Г. Матишов, И.В. Карманова, А.Г. Двореикий, С.Ю. Утевский. Ростов н/Д.: Изд-во ЮНЦ РАН, 2014. - 276 с.

489. Фауна и экология губок (Calcarea, Demospongiae) континентального шельфа и батиали Восточно-Приновоземельского желоба Карского моря / Г.С. Морозов, А.В. Голиков, О.С. Любина, P.M. Сабиров // Комплексные исследования природы Шпицбергена и прилегающего шельфа: Матер. Междунар. науч. конф. (Мурманск, 6-8 ноября 2014 г.). Вып. 12. - М.: ГЕОС, 2014. - С. 220-225.

490. Фролов А.А. Фауна, распространение и экология моллюсков надсемейства Pisidioidea различных водных объектов Северо-Запада России: Автореф. дис. ... канд. биол. наук (03.02.08 - экология (биология). - Борок, 2011. - 24 с.

491. Фролов A.A. Особенности биологии Euglesa curta (Clessin, 1874) (Bivalvia: Pisidioidea) в водоемах Мурманской области // Науч. зап. Тернопольского нац. пед. ун-та им. Владимира Гнатюка. - Сер. Биол. - 2012. - № 2(51). - С. 287-290.

492. Фролов А.А. Многолетние исследования пресноводных двустворчатых моллюсков надсемейства Pisidioidea в водоемах севера Мурманской области // Арктическое морское природопользование в XXI веке - современный баланс научных традиций и инноваций (к 80-летию ММБИ КНЦ РАН): Тез. докл. Междунар. науч. конф. (г. Мурманск, 1-3 апреля 2015 г.). - Апатиты: Изд-во КНЦ РАН, 2015. - C. 231-233.

493. Фролова Е.А., Дикаева Д.Р. Сообщества полихет прибрежья Баренцева моря и северной части Белого моря // Глобальные климатические процессы и их влияние на экосистемы арктических и субарктических регионов: Тез. докл. Междунар. науч. конф. (г. Мурманск, 9-11 ноября 2011 г.). - Апатиты: Изд-во КНЦ РАН, 2011. - C. 191-193.

494. Фролова Е.А., Дикаева Д.Р. Биогеографический состав многощетинковых червей фьордов и заливов Западного Шпицбергена // Комплексные исследования природы Шпицбергена: Матер. Междунар. науч. конф. (Мурманск, 1-3 ноября 2012 г.). Вып. 11. - М.: ГЕОС, 2012. - C. 238-248.

495. Фролова Е.А., Дикаева Д.Р. Сообщества полихет архипелага Земля Франца-Иосифа // Север в XXI веке: среда обитания, общество, освоение: Сб. матер. I Междунар. науч.-практ. конф., 1-4 декабря 2014 г. - Мурманск: АНО АЦНИЭ, 2014. - С. 119-123. 
496. Шохин И.В., Набоженко М.В. Stereoderma kirchsbergii (Heller, 1968) (Echinodermata: Holothuroidea: Cucumariidae) в водах кавказского побережья России: первая находка для российского сектора Черного моря // Изучение и освоение морских и наземных экосистем в условиях арктического и аридного климата: Матер. Междунар. науч. конф. (6-11 июня 2011 г., Ростов-на-Дону). - Ростов н/Д.: Изд-во ЮНЦ РАН, 2011. - С. 363-364.

497. Chaban E.M., Nekhaev I.O. Retusa pellucida (Brown, 1827) (Gastropoda: Opisthobranchia: Cephalaspidea) from the Barents Sea - a new species for the fauna of Russian Arctic seas // Zoosystematica Rossca. 2010. - Vol. 19(2). - P. 196-204.

498. Chaban E.M., Nekhaev I.O. Age variability in the shell of Scaphander punctostriatus (Mighels et C.B. Adams, 1842) (Gastropoda: Heterobranchia: Cephalaspidea) as revealed by specimens from the Russian part of the Barents Sea // Zoosystematica Rossica. - 2013. - Vol. 22(2). P. 165-171.

499. Chaban E.M., Nekhaev I.O., Lubin P.A. Hermania indistincta comb. nov. (Gastropoda: Opisthobranchia: Cephalaspidea) from the Barents Sea - new species and genus for the fauna of the Russian Seas // Zoosystematica Rossica. - 2015. - Vol. 24(2). - P. 148-154.

500. Deart Yu.V., Frolov A.A., Manushin I.E. Bivalves Abra prismatica (Montagu, 1808) and Gari fervensis (Gmelin, 1791) - species new to the fauna of the Russian sector of the Barents Sea // Russian J. Biol. Invasions. 2013. - Vol. 4, № 3. - P. 139-148.

501. Decapod Crustaceans of the Barents Sea and adjacent waters: species composition and peculiarities of distribution / O.L. Zimina, P.A. Lyubin, L.L. Jørgensen, D.V. Zakharov, O.S. Lyubina // Arthropoda Selecta. - 2015. - Vol. 24, № 4. - P. 417-428.

502. Dvoretsky A.G. Epibionts of the great spider crab, Hyas araneus (Linnaeus, 1758), in the Barents Sea // Polar Biol. - 2012. - Vol. 35(4). P. 625-631. - Doi: 10.1007/s00300-011-1087-x. - URL: http://www.springerlink. com/content/p271615mhg657763/

503. Dvoretsky A.G., Dvoretsky V.G. Population biology of Ischyrocerus commensalis, a crab-associated amphipod, in the southern Barents Sea: a multi-annual summer study // Marine Ecology. - 2011. - Vol. 32, № 4. P. 498-508. - Doi: 10.1111/j.1439-0485.2011.00450.x

504. Dvoretsky A.G., Dvoretsky V.G. Does spine removal affect molting process in the king red crab (Paralithodes camtschaticus) in the Barents Sea? // Aquaculture. - 2012. - Vol. 326-329. - P. 173-177. - Doi: 10.1016/j.aquaculture. 2011.10.028. - URL: http://www.sciencedirect.com/ science/article/pii/S0044848611008441 
505. Dvoretsky A.G., Dvoretsky V.G. Copepods associated with the red king crab Paralithodes camtschaticus (Tilesius, 1815) in the Barents Sea // Zoological Studies: a Springer Open J. - 2013. - Vol. 52, № 17. - 7 p. Doi: 10.1186/1810-522X-52-17. - URL: http://www.zoologicalstudies.com/ content $/ 52 / 1 / 17$

506. Dvoretsky A.G., Dvoretsky V.G. Population dynamics of the invasive lithodid crab, Paralithodes camtschaticus, in a typical bay of the Barents Sea // J. Marine Sci. - 2013. - Vol. 70(6). - P. 1255-1262. - Doi: 10.1093/icesjms/fst037. - URL: http:/icesjms.oxfordjournals.org/content/70/6.toc

507. Dvoretsky A.G., Dvoretsky V.G. Size-at-age of juvenile red king crab (Paralithodes camtschaticus) in the coastal Barents Sea // Cahiers de Biol. Marine. - 2014. - Vol. 55, № 1. - P. 43-48.

508. Dvoretsky A.G., Dvoretsky V.G. Red king crab in Russia: populations, fisheries, and symbionts // King crabs of the World: biology and fisheries management. - Boca Raton: CRC Press (Taylor\&Francis Group), 2014. - P. 501-518.

509. Dvoretsky A.G., Dvoretsky V.G. Size at maturity of female red king crab, Paralithodes camtschaticus, from the costal zone of Kola Peninsula (southern Barents Sea) // Cahiers de Biol. Marine. - 2015. Vol. 56, № 1. - P. 49-54.

510. Garbul E.A., Anisimova N.A. Some features of the quantitative distribution of sipunculan worms (Sipuncula) in the central and southern Barents Sea // Oceanologia. - 2012. - Vol. 54, № 1. - P. 59-74.

511. Impact of invasive bivalve Anadara kagoshimensis on the Taman Bay (Sea of Azov) benthic assemblages / G.A. Kolyuchkina, S.V. Biryukova, V.L. Semin, U.V. Simakova, A.B. Basin, V.A. Spiridonov, M.V. Nabozhenko // $50^{\text {th }}$ European Marine Biology Symposium, Helgoland, Germany, September 21-25: Book of abstr. - Helgoland, 2015. - P. 59.

512. Internal brooding affects the spatial structure of intertidal sea anemones in the Arctic-boreal region / A. Kaliszewicz, N. Panteleeva, I. Olejniczak, P. Boniecki, M. Sawicki // Polar Biol. - 2012. - Vol. 35. P. 1911-1919. - Doi: 10.1007/s00300-012-1232-1

513. Level mode of the Caspian Sea and the new sight at the islands of the Northern Caspian / G.M. Abdurahmanov, G.A. Teymurov, I.V. Shokhin, M.V. Nabozhenko, S.V. Alieva, S.N. Eskendarova, Z.M. El'derkhanova // The Caspian region: environmental consequences of the climate change. Moscow: MSU, RFBR. P. 60-63.

514. Lyubina O.S., Frolova E.A., Dikaeva D.R. Current zoobenthos monitoring at the Kola Transect in the Barents Sea // Berichte zur Polarforschung. - 2012. - № 640. - P. 177-189. 
515. Nekhaev I.O. Two species of parasitic molluscs new for Russian Seas // Ruthenica. - 2011. - Vol. 21, № 1. - P. 69-72.

516. Nekhaev I.O. Distributional notes on Gibbula cineraria (Linnaeus, 1758), Pseudosetia turgida (Jeffreys, 1870) and Haliella stenostoma (Jeffreys, 1858) in Russian part of the Barents Sea (Gastropoda) // Ruthenica. - 2013. - Vol. 23, № 1. - P. 35-39.

517. Nekhaev I.O. The first record of Alvania punctura from Russian waters (Gastropoda: Rissoidae) // Marine Biodiversity Records. - 2013. Vol. 6, № 2. - P. 1-3. - Doi: 10.1017/S1755267212001145

518. Nekhaev I.O. Marine shell-bearing Gastropoda of Murman (Barents Sea): an annotated check-list // Ruthenica. - 2014. - Vol. 24, № 2. - P. 75-121.

519. Nekhaev I.O. New records of gadilid molluscs from the southwestern Barents Sea (Scaphopoda: Gadilidae) // Ruthenica. - 2015. Vol. 25, № 2. - P. 69-71.

520. Nekhaev I.O. Occurence of Obtusella intersecta in the Barents Sea (Mollusca: Gastropoda: Rissoidae) // Zoosystematica Rossica. - 2015. Vol. 24(1). - P. 3-8.

521. Nekhaev I.O. Surviving at the edge of land: finding of the limnetic snail Sibirenauta sibirica (Gastropoda: Physidae) on the coast of the Laptev Sea (Eastern Siberia) // Bull. Russian Malacol. Soc. - 2015. Vol. 19. - P. 25-30.

522. Nekhaev I.O., Kantor Yu.I. The first record of Thesbia nana (Lovén, 1846) (Gastropoda: Conoidea) in Russian waters // Ruthenica. 2012. - № 22(2). - P. 51-54.

523. Nekhaev I.O., Deart Yu.V., Lubin P.A. Molluscs of the genus Onoba H. Adams et A. Adams, 1852 from the Barents Sea and adjacent waters (Gastropoda: Rissoidae) // Proceedings of the Zoological Institute of Russian Academy of Sciences. - 2014. - Vol. 318(3). - P. 268-279.

524. Nekhaev I.O., Schiøtte T., Vinarski M.V. Type materials of European freshwater mollusks described by Otto Friedrich Müller // Archiv für Molluskenkunde. - 2015. - Vol. 144, iss. 1. - P. 51-64.

525. Pavlova L.V. Ration of the red king crab on coastal shoals of the Barents Sea // Doklady Biol. Sci. - 2015. - Vol. 463, № 1. - P. 200-204.

526. Sikorski A.V., Pavlova L.V. New species of Scolelepis (Polychaeta, Spionidae) from the Norwegian coast and Barents Sea with a brief review of the genus // Fauna Norvegica. - 2015. - Vol. 35. - P. 9-19. 
527. Sukhotin A., Regel K., Krasnov Y. When mussels are most tasty: seasonal variation of caloric value and tissue biochemical composition of Mytilus in the north. A variety of interactions in marine environment // A variety of interactions in marine environment: Abstr. 49 $9^{\text {th }}$ EMBS (September 8-12, 2014, St.-Petersburg). - St.-Petersburg, 2014. - P. 24-25. URL: http://www.onlinereg.ru/EMBS49/EMBS.pdf

528. Svitina $V$., Gudimov A. Estuarine population of Semibalanus balanoides in gradient of limiting factors in the Kola Bay // A variety of interactions in marine environment: Abstr. 49 ${ }^{\text {th }}$ EMBS (September 8-12, 2014, St.-Petersburg). - St.-Petersburg, 2014. - P. 16-17. - URL: http:// www.onlinereg.ru/EMBS49/EMBS.pdf

529. Type materials of freshwater gastropod species described by C.A. Westerlund and accepted in current malacological taxonomy: a taxonomic and nomenclatorial study / M.V. Vinarski, I.O. Nekhaev, P. Glöer, T. Proschwitz von // Ruthenica. - 2013. - Vol. 23, № 2. - P. 79-108.

\section{Водоросли-макрофиты. Водная растительность}

530. Адаптация и регуляция роста у макрофитов Баренцева моря / Г.М. Воскобойников, М.В. Макаров, С.В. Малавенда, И.В. Рыжсик // Вестн. Кольского науч. центра РАН. - 2015. - № 2(21). - С. 40-48.

531. Водоросли, сосудистые растения и лишайники Мурманского побережья Баренцева моря (аннотированный список видов) / Е.Ф. Марковская, С.В. Малавенда, И.В. Рыжик, Л.А. Сергиенко, A.B. Сонина. - Петрозаводск: Изд-во Петрозав. гос. ун-та, 2013. -69 с.

532. Воскобойников Г.М. Адаптационная способность морских макрофитов Баренцева моря // Ботанические сады и устойчивое развитие северных регионов: Матер. Всерос. науч. конф. с междунар. участием, посвященной 80-летнему юбилею ПАБСИ КНЦ РАН, АпатитыКировск, 25-28 августа 2011 г. - Апатиты: Изд-во К\&M, 2011. - С. 44-48.

533. Воскобойников Г.М. Ультраструктура энергетического аппарата у макроводорослей высоких широт в условиях темноты // Комплексные исследования природы Шпицбергена и прилегающего шельфа: Матер. Междунар. науч. конф. (Мурманск, 6-8 ноября 2014 г.). Вып. 12. - М.: ГЕОС, 2014. - C. 39-41.

534. Воскобойников Г.М. Исследования адаптации, регуляции роста и использования макрофитов Баренцева моря: связь времен // Арктическое морское природопользование в XXI веке - современный баланс научных традиций и инноваций (к 80-летию ММБИ КНЦ РАН): Тез. докл. Междунар. науч. конф. (г. Мурманск, 1-3 апреля 2015 г.). Апатиты: Изд-во КНЦ РАН, 2015. - С. 32-33. 
535. Воскобойников Г.М., Макаров М.В. Влияние темноты и температуры на водоросли арктических морей // Комплексные исследования природы Шпицбергена: Матер. Междунар. науч. конф. (Мурманск, 1-3 ноября 2012 г.). Вып. 11. - М.: ГЕОС, 2012. - С. 38-42.

536. Воскобойников Г.М., Макаров М.В., Рыжик И.В. Влияние факторов внешней среды на существование водорослей-макрофитов арктических морей // Биоразнообразие и устойчивое развитие: Матер. докл. III Междунар. науч.-практ. конф. (Симферополь, 15-19 сентября 2014 г.). - Симферополь: Изд. Крым. науч. центра, 2014. - С. 67-68.

537. Громов В.В. Состояние и перспективы развития донной морской растительности Черного моря на Северо-Кавказском шельфе // Состояние экосистем шельфовой зоны Черного и Азовского морей в условиях антропогенного воздействия. - Краснодар: Изд-во Кубан. гос. ун-та, 2011. - С. 38-45.

538. Громов В.В. Водная и прибрежно-водная растительность северного и западного побережья Азовского моря // Журн. Сибирского федерального ун-та. Сер. Биол. - 2012. - Т.5, № 2. - С. 121-137.

539. Громов B.B. Макрофитобентос южных морей России. Водоросли Северо-Кавказского побережья Черного моря, прибрежноводная растительность Азовского моря и Северного Каспия. Саарбруккен: Palmarium Acad. Publ., 2012. - 337 с.

540. Громов В.В. Несколько замечаний о методе Браун-Бланке в морской гидроботанике // Арктическое морское природопользование в XXI веке - современный баланс научных традиций и инноваций (к 80-летию ММБИ КНЦ РАН): Тез. докл. Междунар. науч. конф. (г. Мурманск, 1-3 апреля 2015 г.). - Апатиты: Изд-во КНЦ РАН, 2015. - C. 43.

541. Громов B.B., Милютина Н.П. Адаптации доминирующих водорослей к меняющимся условиям среды Азовского моря // Экосистемные исследования среды и биотв Азовского бассейна. Ростов н/Д.: Изд-во ЮНЦ РАН, 2012. - С. 140-158.

542. Динамика фитообрастания крупно-обломочного материала на литорали Мурмана / С.С. Малавенда, С.В. Малавенда, М.В. Митяев, M.В. Герасимова // Pontus Euxinus 2015: Тез. IX Всерос. науч.-практ. конф. молодых ученых по проблемам водных экосистем, посвященной 100летию со дня рождения д.б.н., проф., чл.-корр. АН УССР В.Н. Грёзе (17-20 ноября 2015 г.). - Севастополь: DigitPrint, 2015. - С. 104-106.

543. Динамика фитообрастания крупно-обломочного материала на литорали Мурмана / С.С. Малавенда, М.В. Митяев, С.В. Малавенда, М.В. Герасимова // Современные эколого-биологические и химические 
исследования, техника и технология производств: Матер. Междунар. науч.-практ. конф., Мурманск, 7 апреля 2015 г.: В 2-х ч. - Мурманск: Изд-во Мурм. гос. техн. ун-та, 2015. - Ч. 1. - С. 140-146.

544. Клиндух М.П. Динамика содержания свободного пролина в бурой водоросли Fucus vesiculosus // Материалы XXIX конференции молодых ученых Мурманского морского биологического института, посвященной 140-летию со дня рождения Г.А. Клюге, «Морские исследования экосистем европейской Арктики» (г. Мурманск, май 2011 г.). - Мурманск: Изд. ММБИ КНЦ РАН, 2011. - С. 105-109.

545. Клиндух М.П. Содержание пролина в бурой водоросли Fucus vesiculosus L.: природные и экспериментальные данные // Вестн. Южного науч. центра РАН. - 2011. - Т. 7, № 4. - С. 61-65.

546. Клиндух М.П. Содержание маннита и свободного пролина в бурой водоросли Fucus vesiculosus Мурмана // Биоресурсы и аквакультура: Тез. докл. Школы молодых ученых по морской биологии (Мурманск, 28-29 февраля 2012 г.). - Мурманск: Изд-во Мурм. гос. техн. ун-та, 2012. - С. 21-23.

547. Клиндух М.П. Содержание некоторых свободных аминокислот в бурой водоросли Fucus vesiculosus бухты Белокаменная Кольского залива Баренцева моря // Материалы XXX юбилейной конференции молодых ученых Мурманского морского биологического института, посвященной 150 -летию со дня рождения Н.М. Книповича, «Проблемы океанографии, биологии и освоения биоресурсов морей российской Арктики» (г. Мурманск, май 2012). - Мурманск: Изд. ММБИ КНЦ PAH, 2012. - C. 90-97.

548. Клиндух М.П. Влияние концентрации тяжелых металлов на содержание свободного пролина в бурой водоросли Fucus vesiculosus в природе и в эксперименте [Электронный ресурс] // Наука и образование - 2013: Матер. Междунар. науч.-техн. конф., Мурманск, 4-11 марта 2013 г. - Электрон. текст. дан. (220 Мб). - Мурманск: Изд-во Мурм. гос. техн. ун-та, 2013. - С. 243-244. - 1 электрон. опт. диск (CD-ROM). - Систем. требования: PC не ниже класса Pentium II; $128 \mathrm{Mb}$ RAM; свободное место на HDD $130 \mathrm{Mb}$; дисковод CD-ROM 2-х и выше. - Электрон. текст подг. ФГБОУ ВПО «МГТУ». - № гос. регистрации 0321301202.

549. Клиндух М.П. Содержание маннита, белка и свободных аминокислот в бурых водорослях $F$. vesiculosus и A. nodosum Баренцева, Белого и Балтийского морей // Материалы XXXI конференции молодых ученых Мурманского морского биологического института, посвященной 135 -летию со дня рождения К.М. Дерюгина, «Океанография и биология арктических морей» (г. Мурманск, май 2013). - Мурманск: Изд. ММБИ КНЦ РАН, 2013. - С. 108-113. 
550. Клиндух М.П. Сравнение методов извлечения свободных аминокислот из фукусовых водорослей // Эколого-эволюционные исследования морских организмов и экосистем: Матер. XIV Междунар. науч. конф. студентов и аспирантов «Проблемы Арктического региона» (г. Мурманск, май 2014 г.). Т. І. Форум молодых ученых, посвященный 110-летию со дня рождения Ю.И. Полянского (XXXII конференция молодых ученых ММБИ). - Мурманск: Изд. ММБИ КНЦ PAH, 2014. - C. 76-82.

551. Клиндух М.П. Исследование свободных аминокислот бурых и красныХ водорослей Баренцева моря методом ВЭЖХ // Арктическое морское природопользование в XXI веке - современный баланс научных традиций и инноваций (к 80-летию ММБИ КНЦ РАН): Тез. докл. Междунар. науч. конф. (г. Мурманск, 1-3 апреля 2015 г.). Апатиты: Изд-во КНЦ РАН, 2015. - С. 107-109.

552. Клиндух М.П., Облучинская Е.Д. Свободный пролин Fuсиs vesiculosus: в природе и эксперименте // Глобальные климатические процессы и их влияние на экосистемы арктических и субарктических регионов: Тез. докл. Междунар. науч. конф. (г. Мурманск, 9-11 ноября 2011 г.). - Апатиты: Изд-во КНЦ РАН, 2011. - С. 86-88.

553. Клиндух М.П., Облучинская Е.Д. Сравнительное исследование химического состава бурых водорослей Fucus vesiculosus и Ascophyllum nodosum // Вестн. Мурм. гос. техн. ун-та. - 2013. - Т. 16, № 3. - С. 466-471.

554. Клиндух М.П., Облучинская Е.Д. Содержание свободных аминокислот в разных частях таллома и в онтогенезе бурой водоросли Fucus vesiculosus // Современные эколого-биологические и химические исследования, техника и технология производств: Матер. Междунар. науч.-практ. конф., Мурманск, 7 апреля 2015 г.: В 2-х ч. - Мурманск: Изд-во Мурм. гос. техн. ун-та, 2015. - Ч. 1. - С. 222-226.

555. Клиндух М.П., Облучинская Е.Д., Матишов Г.Г. Сезонные изменения содержания маннита и пролина в бурой водоросли Fucus vesiculosus (L.) Мурманского побережья Баренцева моря // Докл. РАН. 2011. - T. 441, № 1. - C. 133-136.

556. Колбеева М.В., Фисак Е.М., Рыжик И.В. Влияние дизельного топлива на активность каталазы в клетках Fucus vesiculosus // Проблемы Арктического региона: Пятнадцатая Междунар. науч. конф. студентов и аспирантов (г. Мурманск, 14 мая 2015 г.): Тез. докл. - Ростов н/Д.: Изд-во ЮНЦ РАН, 2015. - C. 76-77. - URL: http://www.mmbi.info/publikatsii/n52/

557. Комракова Д.Г., Малавенда С.С., Малавенда С.В. Литоральные фитоценозы защищенных участков Кольского залива и Ура-губы // Проблемы Арктического региона: 12-я Междунар. науч. конф. студентов и аспирантов, г. Мурманск, май 2012 г.: Тез. конф. - Мурманск: Изд. ММБИ КНЦ РАН, 2012. - С. 62-63. 
558. Комракова Д.Г., Малавенда С.С., Малавенда С.В. Изменения в литоральных фитоценозах Мурмана при антропогенном воздействии // Проблемы Арктического региона: 13-я Междунар. науч. конф. студентов и аспирантов, г. Мурманск, май 2013 г.: Тез. конф. - Мурманск: Изд. ММБИ КНЦ РАН, 2013. - С. 29-30.

559. Кудрявиева Е.О., Воскобойников Г.М., Голяк И.В. Строение энергетического аппарата у Laminaria latissima на ранних стадиях онтогенеза // Арктическое морское природопользование в XXI веке современный баланс научных традиций и инноваций (к 80-летию ММБИ КНЦ РАН): Тез. докл. Междунар. науч. конф. (г. Мурманск, 1-3 апреля 2015 г.). - Апатиты: Изд-во КНЦ РАН, 2015. - С. 121-123.

560. Кудрявиева Е.О., Воскобойников Г.М., Голяк И.В. Строение энергетического аппарата у Saccharina latissima на ранних стадиях онтогенеза // Проблемы Арктического региона: Пятнадцатая Междунар. науч. конф. студентов и аспирантов (г. Мурманск, 14 мая 2015 г.): Тез. докл. - Ростов н/Д.: Изд-во ЮНЦ РАН, 2015. - С. 79-80. URL: http://www.mmbi.info/publikatsii/n52/

561. Макаров M.В. Влияние гидростатического давления на вертикальную зональность Laminaria saccharina (L.) Lamouroux Баренцева моря // Океанология. - 2011. - Т. 51, № 3. - С. 485-493.

562. Макаров М.В. Светособирающий комплекс бурой водоросли Fucus vesiculosus L. Баренцева моря // Изучение и освоение морских и наземных экосистем в условиях арктического и аридного климата: Матер. Междунар. науч. конф. (6-11 июня 2011 г., Ростов-на-Дону). Ростов н/Д.: Изд-во ЮНЦ РАН, 2011. - С. 287-290.

563. Макаров М.В. Стандартные методы расчетов физиологических показателей водорослей. Иллюзия достоверности // Глобальные климатические процессы и их влияние на экосистемы арктических и субарктических регионов: Тез. докл. Междунар. науч. конф. (г. Мурманск, 9-11 ноября 2011 г.). - Апатиты: Изд-во КНЦ РАН, 2011.- C. 121-123.

564. Макаров М.В. Адаптация светособирающего комплекса бурой водоросли Fucus vesiculosus L. Баренцева моря к условиям освещения // Докл. РАН. - 2012. - Т. 442, № 6. - С. 845-849.

565. Макаров М.B. Распределение фотосинтетических пигментов по таллому Saccharina latissima в различных гидродинамических условиях // Экологическая безопасность приморских регионов (порты, берегозащита, рекреация, марикультура): Матер. Междунар. науч. конф., посвященной 150-летию Н.М. Книповича (Ростов-на-Дону, 5-8 июня 2012 г.). - Ростов н/Д.: Изд-во ЮНЦ РАН, 2012. - С. 144-147. 
566. Макаров М.В. Гидростатическое давление и вертикальное распределение водорослей // Арктическое морское природопользование в XXI веке - современный баланс научных традиций и инноваций (к 80-летию ММБИ КНЦ РАН): Тез. докл. Междунар. науч. конф. (г. Мурманск, 1-3 апреля 2015 г.). - Апатиты: Изд-во КНЦ РАН, 2015. - C. 150-151.

567. Макаров М.В., Воскобойников Г.М. Влияние освещения и температуры на макроводоросли Баренцева моря // Тр. Кольского науч. центра РАН. - 2013. - Т. 1(14). - Сер. Океанология. - Вып. 1. - С. 95-111.

568. Макаров М.В., Рыюик И.В., Воскобойников Г.М. Влияние глубины произрастания на морфофизиологические показатели Fucus vesiculosus L. Баренцева моря // Альгология. - 2012. - Т. 22, № 4. C. 345-360.

569. Малавенда C.B. Видовое разнообразие литоральных макрофитов Восточного Мурмана // Материалы XXIX конференции молодых ученых Мурманского морского биологического института, посвященной 140летию со дня рождения Г.А. Клюге, «Морские исследования экосистем европейской Арктики» (г. Мурманск, май 2011 г.). - Мурманск: Изд. ММБИ КНЦ РАН, 2011. - С. 127-133.

570. Малавенда С.В. Устойчивость фукоидов Баренцева моря к переменной солености // Бот. журн. - 2011. - Т. 96, № 3. - С. 342-349.

571. Малавенда С.В. Влияние абиотических факторов на видовое разнообразие водорослей-макрофитов Восточного Мурмана // Глобальные климатические процессы и их влияние на экосистемы арктических и субарктических регионов: Тез. докл. Междунар. науч. конф. (г. Мурманск, 9-11 ноября 2011 г.). - Апатиты: Изд-во КНЦ РАН, 2011. - C. 128-129.

572. Малавенда C.B. Структура сообществ Saccharina latissima (Phaeophyceae) Баренцева моря // Материалы II (X) Международной ботанической конференции молодых ученых (г. Санкт-Петербург, 11-16 ноября 2012). - СПб.: ЛЭТИ, 2012. - С. 36.

573. Малавенда С.В. Зависимость видового разнообразия водорослей-макрофитов от абиотических факторов в ряде губ Мурманского побережья Баренцева моря (Россия) // Актуальные проблемы современной альгологии: Тез докл. IV Междунар. конф. (23-25 мая 2012 г., г. Киев, Украина). - Киев: Изд. Ин-та ботаники им. Н.Г. Холодного НАН Украины, 2012. - С. 184-186.

574. Малавенда C.В. Донные фитоценозы Кольского залива Баренцева моря // Водоросли: проблемы таксономии, экологии и использование в мониторинге: Матер. докл. III Междунар. науч.-практ. конф. - Ярославль: Изд. Ин-та биол. внутр. вод им. И.Д. Папанина, 2014. - C. 160-161. 
575. Малавенда C.В. Особенности макрофитобентоса Грён-фьорда архипелага Шпицберген // Комплексные исследования природы Шпицбергена и прилегающего шельфа: Матер. Междунар. науч. конф. (Мурманск, 6-8 ноября 2014 г.). Вып. 12. - М.: ГЕОС, 2014. - С. 190-196.

576. Малавенда С.В. Пространственно-видовая структура донных фитоценозов Грён-фьорда архипелага Шпицберген // Экологоэволюционные исследования морских организмов и экосистем: Матер. XIV Междунар. науч. конф. студентов и аспирантов «Проблемы Арктического региона» (г. Мурманск, май 2014 г.). Т. I. Форум молодых ученых, посвященный 110 -летию со дня рождения Ю.И. Полянского (XXXII конференция молодых ученыХ ММБИ). Мурманск: Изд. ММБИ КНЦ РАН, 2014. - С. 96-105.

577. Малавенда C.B. Распределение макрофитобентоса в Кольском заливе Баренцева моря // Современные проблемы экологии и природопользования: Матер. регион. науч.-практ. конф., посвященной 15-летию со дня основания кафедры биоэкологии, Мурманск, 27-28 февраля 2014 г. - Мурманск: Изд-во Мурм. гос. техн. ун-та, 2014. - С. 159-160.

578. Малавенда С.В., Макаров М.В. Структура пояса Saccharina latissima в губе Зеленецкая Баренцева моря [Электронный ресурс] // Наука и образование - 2012: Матер. Междунар. науч.-техн. конф., Мурманск, 2-6 апреля 2012 г. - Электрон. текст. дан. (30 Мб). Мурманск: Изд-во Мурм. гос. техн. ун-та, 2012. С. 326-328. 1 электрон. опт. диск (CD-ROM). - Систем. требования: PC не ниже класса Pentium II; 128 Mb RAM; свободное место на HDD 130 Мб; дисковод CD-ROM 2-х и выше. - Загл. с экрана. - Электрон. текст подг. ФГБОУ ВПО «МГТУ». - № гос. регистрации 0321201101.

579. Малавенда С.В., Макаров М.В. Структура сублиторальных фитоценозов защищенной губы Зеленецкая Мурманского побережья Баренцева моря [Электронный ресурс] // Вопросы современной альгологии. - 2014. - № 1(5). - URL: http://algology.ru/472

580. Малавенда С.В., Метельский А.А. Ассоциации ламинариевых водорослей губ Ивановская и Дроздовка Восточного Мурмана // Вестн. Мурм. гос. техн. ун-та. - 2013. - Т. 16, № 3. - С. 493-500.

581. Малавенда С.В., Метельский А.А. Современное состояние сублиторальных фитоценозов губ Ивановская и Дроздовка Восточного Мурмана [Электронный ресурс] // Наука и образование - 2013: Матер. Междунар. науч.-техн. конф., Мурманск, 4-11 марта 2013 г. - Электрон. текст. дан. (220 Мб). - Мурманск: Изд-во Мурм. гос. техн. ун-та, 2013. C. 258-260. - 1 электрон. опт. диск (CD-ROM). - Систем. требования: PC не ниже класса Pentium II; $128 \mathrm{Mb}$ RAM; свободное место на HDD $130 \mathrm{Mb}$; дисковод CD-ROM 2-х и выше. - Электрон. текст подг. ФГБОУ ВПО «МГТУ». - № гос. регистрации 0321301202. 
582. Малавенда С.В., Комракова Д.Г., Малавенда С.С. Изменения структуры литоральных фитоценозов Мурмана при антропогенном воздействии // Вестн. Мурм. гос. техн. ун-та. - 2013. - Т. 16, № 3. С. 486-492.

583. Малавенда С.С., Малавенда С.В. Донные фитоценозы южного и среднего колен Кольского залива Баренцева моря // Материалы XXX юбилейной конференции молодых ученых Мурманского морского биологического института, посвященной 150-летию со дня рождения H.М. Книповича, «Проблемы океанографии, биологии и освоения биоресурсов морей российской Арктики» (г. Мурманск, май 2012). Мурманск: Изд. ММБИ КНЦ РАН, 2012. - С. 116-122.

584. Малавенда С.С., Малавенда С.В. Современное состояние донных фитоценозов Кольского залива Баренцева моря // Современные проблемы и перспективы рыбохозяйственного комплекса: Матер. III науч.-практ. конф. молодых ученых ФГУП ВНИРО с междунар. участием. - М.: Изд-во ВНИРО, 2012 - С. 47-50.

585. Малавенда С.С., Малавенда С.В. Современное состояние макрофитобентоса Кольского залива Баренцева моря // Материалы Всероссийской конференции молодых ученых и специалистов с международным участием, посвященной 90-летию со дня постройки первого научно-исследовательского судна ПИНРО «Персей». Мурманск: Изд-во ПИНРО, 2012. - С. 178-183.

586. Малавенда С.C., Малавенда С.В. Черты деградации в фитоценозах южного и среднего коле Кольского залива Баренцева моря // Вестн. Мурм. гос. техн. ун-та. - 2012. - Т. 15, № 4. - С. 794-802.

587. Матишов Г.Г., Коломийчук В.П., Польшина Т.Н. Флористическое районирование береговой зоны Азовского моря // Вестн. Южного науч. центра РАН. - 2014. - Т. 10, № 1. - С. 55-59.

588. Метельский A.A. Макроэпифитные сообщества фукусовых водорослей Кольского залива и восточного побережья Мурмана (на примере губ Ярнышная и Зеленецкая) // Материалы XXIX конференции молодых ученых Мурманского морского биологического института, посвященной 140 -летию со дня рождения Г.А. Клюге, «Морские исследования экосистем европейской Арктики» (г. Мурманск, май 2011 г.). - Мурманск: Изд. ММБИ КНЦ РАН, 2011. - С. 141-147.

589. Метельский A.A. Макроэпифитные сообщества фукусовых водорослей Кольского залива и губ Восточного Мурмана: видовой состав, распределение, сезонная динамика // Биоресурсы и аквакультура: Тез. докл. Школы молодых ученых по морской биологии (Мурманск, 28-29 февраля 2012 г.). - Мурманск: Изд-во Мурм. гос. техн. ун-та, 2012. - С. 30-31. 
590. Метельский A.A. Ламинариевые водоросли и их эпифиты губ Дроздовка и Ивановская Восточного Мурмана // Материалы XXX юбилейной конференции молодых ученых Мурманского морского биологического института, посвященной 150-летию со дня рождения Н.М. Книповича, «Проблемы океанографии, биологии и освоения биоресурсов морей российской Арктики» (г. Мурманск, май 2012). Мурманск: Изд. ММБИ КНЦ РАН, 2012. - С. 122-126.

591. Метельский А.А. К флоре макроводорослей Печорского моря // Вестн. Южного науч. центра РАН. - 2014. - Т. 10, № 1. - С. 50-54.

592. Метельский A.A. Макрофиты открытой части Печорского моря // Эколого-эволюционные исследования морских организмов и экосистем: Матер. XIV Междунар. науч. конф. студентов и аспирантов «Проблемы Арктического региона» (г. Мурманск, май 2014 г.). Т. I. Форум молодых ученых, посвященный 110-летию со дня рождения Ю.И. Полянского (XXXII конференция молодых ученых ММБИ). Мурманск: Изд. ММБИ КНЦ РАН, 2014. - С. 108-112.

593. Метельский А.А., Малавенда С.В. Сублиторальные ассоциации макрофитобентоса губ Ивановская и Дроздовка Восточного Мурмана // Материалы XXXI конференции молодых ученых Мурманского морского биологического института, посвященной 135-летию со дня рождения К.М. Дерюгина, «Океанография и биология арктических морей» (г. Мурманск, май 2013). - Мурманск: Изд. ММБИ КНЦ РАН, 2013. - C. 131-136.

594. Облучинская Е.Д. Биологически активные вещества фукоидов Баренцева моря: биохимические и технологические аспекты // Глобальные климатические процессы и их влияние на экосистемы арктических и субарктических регионов: Тез. докл. Междунар. науч. конф. (г. Мурманск, 9-11 ноября 2011 г.). - Апатиты: Изд-во КНЦ PAH, 2011. - C. 141-142.

595. Облучинская Е.Д. Биохимические аспекты адаптации фукоидов Баренцева моря // Изучение и освоение морских и наземных экосистем в условиях арктического и аридного климата: Матер. Междунар. науч. конф. (6-11 июня 2011 г., Ростов-на-Дону). - Ростов н/Д.: Изд-во ЮНЦ РАН, 2011. - С. 300-302.

596. Облучинская Е.Д. Влияние факторов внешней среды на содержание полисахаридов фукуса пузырчатого Fucus vesiculosus L. // Химия растительного сырья. - 2011. - № 3. - С. 47-51.

597. Облучинская Е.Д. Содержание полифенолов бурой водоросли Fucus distichus L. // Высокие технологии, фундаментальные и прикладные исследования в физиологии и медицине: Матер. Междунар. науч. конф. - СПб.: Изд. Политехн. ун-та, 2012. - С. 45-47. 
598. Облучинская Е.Д., Алешина Е.Г., Матишов Д.Г. Содержание тяжелых металлов и мышьяка в донных отложениях и в фукоидах Мурманского побережья Баренцева моря // Экологическая безопасность приморских регионов (порты, берегозащита, рекреация, марикультура): Матер. Междунар. науч. конф., посвященной 150-летию Н.М. Книповича (Ростов-на-Дону, 5-8 июня 2012 г.). - Ростов н/Д.: Изд-во ЮНЦ РАН, 2012. - C. 174-177.

599. Перемотина А.Г., Облучинская Е.Д. Фенолы бурых водорослей (Fucus distichus) Баренцева моря // 2013 год - год охраны окружающей среды в России: Тез. докл. конф. молодых ученых (Мурманск, 12-13 февраля 2013 г.). - Мурманск: Изд-во Мурм. гос. техн. ун-та, 2013. - С. 54-55.

600. Пуговкин Д.В., Рыљжик И.В. О возможности стерилизации водоросли Fucus vesiculosus ульрафиолетовым излучением // Материалы $\mathrm{XXX}$ юбилейной конференции молодых ученых Мурманского морского биологического института, посвященной 150-летию со дня рождения Н.М. Книповича, «Проблемы океанографии, биологии и освоения биоресурсов морей российской Арктики» (г. Мурманск, май 2012). - Мурманск: Изд. ММБИ КНЦ РАН, 2012. - С. 148-151.

601. Рентгено-флуоресцентный спектрометр с полным внешним отражением для элементного анализа водорослей-макрофитов / В.М. Разномазов, Н.М. Новиковский, В.О. Пономаренко, В.В. Громов, Е.Г. Алёшина // Экология промышленного производства. - 2011. №. 1. - С. 60-74.

602. Рыжик И.В. Метаболическая активность клеток Fucus vesiculosus Linnaeus, 1753 (Phaeophyta: Fucales) из Баренцева моря в условиях нефтяного загрязнения // Биология моря. - 2012. - Т. 38, № $1 .-$ С. $86-88$.

603. Рыжик И.В. Сезонная и суточная динамика метаболической активности клеток Fucus vesiculosus L. Баренцева моря // Актуальные проблемы современной альгологии: Тез докл. IV Междунар. конф. (23-25 мая 2012 г., г. Киев, Украина). - Киев: Изд. Ин-та ботаники им. Н.Г. Холодного НАН Украины, 2012. - С. 254-255.

604. Рыжик И.В. Оценка метаболической активности клеток фукусовых водорослей тетразолиевым методом // Альгология. - 2013. Т. 23, № 1. - С. 10-17.

605. Рыжик И.В. Содержание растворимых флоротаннинов у Fucus vesiculosus L. Кольского залива // Современные проблемы экологии и природопользования: Матер. регион. науч.-практ. конф., посвященной 15-летию со дня основания кафедры биоэкологии, Мурманск, 27-28 февраля 2014 г. - Мурманск: Изд-во Мурм. гос. техн. ун-та, 2014. - С. 192-195. 
606. Рыжик И.В. Активные формы кислорода - как начальный этап процесса адаптации Fucus vesiculosus к периоду осушения // Арктическое морское природопользование в XXI веке - современный баланс научных традиций и инноваций (к 80-летию ММБИ КНЦ РАН): Тез. докл. Междунар. науч. конф. (г. Мурманск, 1-3 апреля 2015 г.). Апатиты: Изд-во КНЦ РАН, 2015. - С. 208-209.

607. Рыжик И.В. Изменение физиологических показателей литоральных водорослей в период отлива [Электронный ресурс] // Растения в условиях глобальных и локальных природно-климатических и антропогенных воздействий: Матер. VIII съезда общ-ва физиологов растений России (21-26 сентября 2015, г. Петрозаводск). - Петрозаводск: Изд. КарНЦ РАН, 2015. - C. 460. - URL: http://resources.krc.karelia.ru/ib/ doc/conference/kniga_sezd_ofr-11_final.pdf

608. Рыжик И.В., Ващенко А.В. Метаболическая активность клеток Fucus vesiculosus Баренцева моря: сезонные изменения // Глобальные климатические процессы и их влияние на экосистемы арктических и субарктических регионов: Тез. докл. Междунар. науч. конф. (г. Мурманск, 9-11 ноября 2011 г.). - Апатиты: Изд-во КНЦ PAH, 2011. - C. 170.

609. Рыжик И.В., Вильнет А.А. Морфологические формы и гибриды фукусовых водорослей Мурманского побережья Баренцева моря // Биоразнообразие и устойчивое развитие: Матер. докл. III Междунар. науч.-практ. конф. (Симферополь, 15-19 сентября 2014 г.). Симферополь: Изд. Крым. науч. центра, 2014. - С. 313-314.

610. Рыжик И.В., Вильнет A.A. Полиморфизм Fucus distichus Мурманского побережья Баренцева моря // Водоросли: проблемы таксономии, экологии и использование в мониторинге: Матер. докл. III Междунар. науч.-практ. конф. - Ярославль: Изд. Ин-та биол. внутр. вод им. И.Д. Папанина, 2014. - С. 24-26.

611. Рыжсик И.В., Малавенда С.В. Корнманния тонкокожистая Kornmannia leptoderma (Kjellman) Bliding // Красная книга Мурманской области. Изд. 2-е. - Кемерово: Азия-Принт, 2014. - С. 190.

612. Рыљсик И.В., Малавенда С.В. Саккориза кожистая - Saccorhiza dermatodea (Bachelot de la Pylaie) J. Agardh // Красная книга Мурманской области. Изд. 2-е. - Кемерово: Азия-Принт, 2014. - С. 191.

613. Рыжик И.В., Макаров М.В., Воскобойников Г.М. Физиологические состояние литоральных бурых водорослей Fucus serratus Linnaeus, 1753 и Fucus distichus Linnaeus, 1767, произраставших на плантации-биофильтре в Баренцевом море // Биология моря. - 2014. T. 40, № 2. - C. 131-136. 
614. Современное состояние фитоценозов Баренцева моря и прибрежных вод Шпицбергена / Г.М. Воскобойников, М.В. Макаров, С.В. Малавенда, И.В. Рыжик // Морские экосистемы и сообщества в условиях современных климатических изменений. - СПб.: Реноме, 2014. - C. 204-222.

615. Соколова С.В., Колбеева М.В., Рыжик И.В. Распределение растворимых флоротаннинов по таллому Fucus vesiculosus // Проблемы Арктического региона: 12-я Междунар. науч. конф. студентов и аспирантов, г. Мурманск, май 2012 г.: Тез. конф. - Мурманск: Изд. ММБИ КНЦ РАН, 2012. - С. 73.

616. Трофимова Н.В., Облучинская Е.Д. Азот, аминокислоты и белки в бурых водорослях (Fucus serrastus) Баренцева моря // 2013 год год охраны окружающей среды в России: Тез. докл. конф. молодых ученых (Мурманск, 12-13 февраля 2013 г.). - Мурманск: Изд-во Мурм. гос. техн. ун-та, 2013. - С. 66-67.

617. Фитообрастание крупнообломочного материала на валунной литорали Мурманского побережья и сукцессия фитоценозов / С.В. Малавенда, М.В. Митяев, С.С. Малавенда, М.В. Герасимова // Арктическое морское природопользование в XXI веке - современный баланс научных традиций и инноваций (к 80-летию ММБИ КНЦ РАН): Тез. докл. Междунар. науч. конф. (г. Мурманск, 1-3 апреля 2015 г.). Апатиты: Изд-во КНЦ РАН, 2015. - С. 153-155.

618. Микроводоросли в системе биологического мониторинга морских прибрежных экосистем / Е.В. Шошина, Г.М. Воскобойников, М.В. Макаров, С.Е. Завалко, В.И. Капков // Вестн. Мурм. гос. техн. ун-та. - 2012. - Т. 15, № 4. - С. 851-857.

619. Makarov M.V. Adaptation of the light harvesting complex of the Barents Sea brown seaweed Fucus vesiculosus L. to light conditions // Doklady Biol. Sci. - 2012. - Vol. 442. - P. 58-61.

620. Makarov M.V., Voskoboinikov G.M. Effects of light and temperature on the Barents Sea macroalgae // Berichte zur Polarforschung. 2012. № 640. - P. 101-117.

621. Makarov M.V., Ryzhik I.V., Voskoboinikov G.M. The effect of Fucus vesiculosus L. (Phaeophyceae) depth of vegetation in the Barents Sea (Russia) on its morphophysiological parameters // International J. Algae. 2013. - T. 15, № 1. - C. 77-90.

622. Voskoboinikov G., Makarov M., Rizhik I. The influence of polar night on seaweeds of the arctic seas // World conference on marine biodiversity, 12-16 October 2014, Qingdao, China: Abstr. book. - Qingdao, 2014. - P. 243. 


\section{Ихтиология}

623. Берестовский Е.Г. Интродукция радужной форели в водоемы Севера Европы // Современные проблемы экологии и природопользования: Матер. регион. науч.-практ. конф., посвященной 15-летию со дня основания кафедры биоэкологии, Мурманск, 27-28 февраля 2014 г. Мурманск: Изд-во Мурм. гос. техн. ун-та, 2014. - С. 56-59.

624. Воскобойникова О.С., Кудрявиева О.Ю. Развитие костного скелета в онтогенезе пинагора Cyclopterus lumpus (Cyclopteridae, Scorpaeniformes) // Вопросы ихтиологии. - 2014. - Т. 54, № 3. - С. 251-260.

625. Дорофеева E.A., Карамушко О.В. 16. Mallotus villosus (Müller, 1776) - мойва // Рыбы в заповедниках России: В 2-х т. - Т. 2. Морские рыбы. - М.: Тов-во науч. изд. КМК, 2013. С. 62-65.

626. Ихтиофауна прибрежной зоны губ Восточного Мурмана (Ярнышная, Зеленецкая) в летний период 2013 г. / К.И. Ким, О.В. Бондарев, О.Ю. Кудрявщева, С.С. Малавенда // Проблемы Арктического региона: Матер. XIV Междунар. науч. конф. студентов и аспирантов. T. II. Форум студентов и аспирантов: Тез. докл. (г. Мурманск, май 2014 г.). - Мурманск: Изд. ММБИ КНЦ РАН, 2014. - C. 84-85.

627. Ихтиологические исследования арктических морей и сопредельных вод в 2005-2009 гг. / О.В. Карамушко, Н.Г. Журавлева, Л.И. Карамушко, Е.Г. Берестовский, О.Ю. Кудрявиева, Е.В. Расхожева // Комплексные исследования больших морских экосистем России. Апатиты: Изд-во КНЦ РАН, 2011. - С. 155-176.

628. Карамушко Л.И. Энергетика холодноводных морских видов рыб: механизмы и закономерности адаптаций // Глобальные климатические процессы и их влияние на экосистемы арктических и субарктических регионов: Тез. докл. Междунар. науч. конф. (г. Мурманск, 9-11 ноября 2011 г.). - Апатиты: Изд-во КНЦ РАН, 2011. - С. 82-83.

629. Карамушко Л.И. Рост, продукция, метаболизм и адаптации морских видов рыб высоких широт // Докл. РАН. - 2014. - Т. 455, № 4. C. $481-483$.

630. Карамушко Л.И. Биоэнергетические адаптации полярных видов рыб // Арктическое морское природопользование в XXI веке современный баланс научных традиций и инноваций (к 80-летию ММБИ КНЦ РАН): Тез. докл. Междунар. науч. конф. (г. Мурманск, 1-3 апреля 2015 г.). - Апатиты: Изд-во КНЦ РАН, 2015. - С. 101-102. 
631. Карамушко Л.И. Рост, продукция, метаболизм и адаптации морских видов рыб высоких широт // Функционирование и динамика водных экосистем в условиях климатических изменений и антропогенных воздействий: Матер. 5-й Междунар. конф., посвященной памяти выдающегося гидробиолога Г.Г. Винберга (12-17 октября 2015 г., г. Санкт-Петербург, Россия). - СПб.: Лема, 2015. - С. 140.

632. Карамушко Л.И., Christiansen J.S. Bioenergetic adaptations in polar cod Boreogadus saida (Lepechin, 1774) [Электронный ресурс] // XI съезд Гидробиологического общества при Российской академии наук: Тез. докл., Красноярск, 22-26 сент. 2014 г. - Электрон. текст. дан. Красноярск: Изд-во Сибир. фед. ун-та, 2014. - С. 75. - Систем. требования: PC не ниже класса Pentium I; 128 Mb RAM; Windows 98/XP/7; Adobe Reader V8.0 и выше. - Загл. с экрана.

633. Карамушко O.B. 2. Somniosus microcephalus (Bloch \& Schneider, 1801) - полярная акула // Рыбы в заповедниках России: В 2-х т. - Т. 2. Морские рыбы. - М.: Тов-во науч. изд. КМК, 2013. - С. 24-26.

634. Карамушко O.B. 4. Amblyraja radiata (Donovan, 1808) звёздчатый скат // Рыбы в заповедниках России: В 2-х т. - Т. 2. Морские рыбы. - М.: Тов-во науч. изд. КМК, 2013. - С. 30-32.

635. Карамушко O.B. 40. Sebastes mentella Travin, 1951 клювокрылый морской окунь // Рыбы в заповедниках России: В 2-х т. Т. 2. Морские рыбы. - М.: Тов-во науч. изд. КМК, 2013. - С. 126-129.

636. Карамушко O.B. 41. Sebastes norvegicus (Ascanius, 1772) золотистый морской окунь // Рыбы в заповедниках России: В 2-х т. Т. 2. Морские рыбы. - М.: Тов-во науч. изд. КМК, 2013. - С. 129-132.

637. Карамушко O.B. 52. Artediellus atlanticus Jordan \& Evermann, 1898) - атлантический крючкорог // Рыбы в заповедниках России: В 2-х т. Т. 2. Морские рыбы. - М.: Тов-во науч. изд. КМК, 2013. - С. 160-163.

638. Карамушко O.B. 67. Icelus bicornis Reinhardt, 1840 - двурогий ицел, атлантический или арктический ицел // Рыбы в заповедниках России: В 2-х т. - Т. 2. Морские рыбы. - М.: Тов-во науч. изд. КМК, 2013. - C. 197-199.

639. Карамушко O.B. 74. Myохосерhalus scorpius (Linnaeus, 1758) европейский керчак // Рыбы в заповедниках России: В 2-х т. - Т. 2. Морские рыбы. - М.: Тов-во науч. изд. КМК, 2013. - С. 214-217.

640. Карамушко O.B. 81. Triglops murrayi Gunther, 1888 атлантический триглопс // Рыбы в заповедниках России: В 2-х т. - Т. 2. Морские рыбы. - М.: Тов-во науч. изд. КМК, 2013. - С. 230-232. 
641. Карамушко O.B. 87. Cottunculus microps Collett, 1875 малоглазый коттункул // Рыбы в заповедниках России: В 2-х т. - Т. 2. Морские рыбы. - М.: Тов-во науч. изд. КМК, 2013. - С. 246-248.

642. Карамушко O.B. 91. Agonus cataphractus (Linnaeus, 1758)европейская лисичка // Рыбы в заповедниках России: В 2-х т. - Т. 2. Морские рыбы. - М.: Тов-во науч. изд. КМК, 2013. - С. 256-258.

643. Карамуико O.B. 95. Leptagonus decagonus (Bloch and Schneider, 1801) - лисичка-лептагон // Рыбы в заповедниках России: В 2-х т. Т. 2. Морские рыбы. - М.: Тов-во науч. изд. КМК, 2013. - С. 266-269.

644. Карамушко O.B. 103. Ulcina olrikii (Lutken, 1877) - ледовитоморская лисичка, ульцина // Рыбы в заповедниках России: В 2-х т. Т. 2. Морские рыбы. - М.: Тов-во науч. изд. КМК, 2013. - С. 288-290.

645. Карамушко O.B. 127. Lycenchelys sarsii (Collett, 1871) лиценхел Сарса // Рыбы в заповедниках России: В 2-х т. - Т. 2. Морские рыбы. - М.: Тов-во науч. изд. КМК, 2013. - С. 347-349.

646. Карамушко O.B. 131. Lycodes gracilis Sars, 1867 - тонкий ликод Вааля // Рыбы в заповедниках России: В 2-х т. - Т. 2. Морские рыбы. - М.: Тов-во науч. изд. КМК, 2013. - С. 356-358.

647. Карамушко O.B. 132. Licodes marisalbi Knipowitsch, $1906-$ беломорский ликод // Рыбы в заповедниках России: В 2-х т. - Т. 2. Морские рыбы. - М.: Тов-во науч. изд. КМК, 2013. - С. 358-359.

648. Карамушко O.B. 135. Zoarces viviparus (Linnaeus, 1758) европейская бельдюга // Рыбы в заповедниках России: В 2-х т. - Т. 2. Морские рыбы. - М.: Тов-во науч. изд. КМК, 2013. - С. 364-366.

649. Карамушко O.B. 148. Lumpenus fabricii Reinhardt, 1836 люмпен Фабриция // Рыбы в заповедниках России: В 2-х т. - Т. 2. Морские рыбы. - М.: Тов-во науч. изд. КМК, 2013. - С. 394-396.

650. Карамушко O.B. 149. Lumpenus lampretaeformis (Walbaum, 1792) - миноговидный люмпен // Рыбы в заповедниках России: В 2-х т. Т. 2. Морские рыбы. М.: Тов-во науч. изд. КМК, 2013. - С. 396-399.

651. Карамушко O.B. 162. Pholis gunnellus (Linnaeus, 1758) обыкновенный маслюк // Рыбы в заповедниках России: В 2-х т. - Т. 2. Морские рыбы. - М.: Тов-во науч. изд. КМК, 2013. - С. 426-428.

652. Карамушко O.B. 166. Anarhichas denticulatus Køryer, 1769) синяя зубатка // Рыбы в заповедниках России: В 2-х т. - Т. 2. Морские рыбы. - М.: Тов-во науч. изд. КМК, 2013. - С. 434-437.

653. Карамушко O.B. 167. Anarhichas lupus Linnaeus, 1758 обыкновенная зубатка, морской волк // Рыбы в заповедниках России: В 2-х т. - Т. 2. Морские рыбы. - М.: Тов-во науч. изд. КМК, 2013. C. $438-442$. 
654. Карамушко O.B. 168. Anarhichas minor Olafsen, 1772 - пятнистая зубатка // Рыбы в заповедниках России: В 2-х т. - Т. 2. Морские рыбы. М.: Тов-во науч. изд. КМК, 2013. - С. 442-444.

655. Карамушко O.B. 174. Ammodytes marinus Raitt, 1934 европейская многопозвонковая песчанка // Рыбы в заповедниках России: В 2-х т. - Т. 2. Морские рыбы. - М.: Тов-во науч. изд. КМК, 2013. - C. 458-460.

656. Карамушко O.B. 175. Ammodytes tobianus Linnaeus, 1758 европейская малопозвонковая песчанка // Рыбы в заповедниках России: В 2-х т. - Т. 2. Морские рыбы. - М.: Тов-во науч. изд. КМК, 2013. - C. 461-463.

657. Карамушко O.B. Разнообразие и структура ихтиофауны северных морей России // Тр. Кольского науч. центра РАН. - 2013. Т. 1(14). - Сер. Океанология. - Вып. 1. - С. 127-135.

658. Карамушко O.В. Видовой состав и структура ихтиопланктона Баренцева, Белого и Карского морей // Арктическое морское природопользование в XXI веке - современный баланс научных традиций и инноваций (к 80-летию ММБИ КНЦ РАН): Тез. докл. Междунар. науч. конф. (г. Мурманск, 1-3 апреля 2015 г.). - Апатиты: Изд-во КНЦ РАН, 2015. - С. 102-103.

659. Карамушко O.В., Попова О.A. 25. Melanogrammus aeglefinus (Linnaeus, 1758) - пикша // Рыбы в заповедниках России: В 2-х т. - Т. 2. Морские рыбы. - М.: Тов-во науч. изд. КМК, 2013. - С. 87-89.

660. Карамушко O.B., Попова O.A. 26. Pollachius virens (Linnaeus, 1758) - сайда // Рыбы в заповедниках России: В 2-х т. - Т. 2. Морские рыбы. М.: Тов-во науч. изд. КМК, 2013. - С. 90-92.

661. Карамушко O.B., Решетников Ю.C. 7. Raja fyllae Lütken, 1887 - круглый скат // Рыбы в заповедниках России: В 2-х т. - Т. 2. Морские рыбы. М.: Тов-во науч. изд. КМК. 2013. С. 39-41.

662. Карамушко О.В., Решетников Ю.С. 82. Triglops pingelii Reinhardt, 1837 - остроносый триглопс // Рыбы в заповедниках России: В 2-х т. - Т. 2. Морские рыбы. - М.: Тов-во науч. изд. КМК, 2013. C. $232-235$.

663. Карамушко О.В., Решетников Ю.С. 92. Aspidophoroides bartoni Gilbert, 1896 - лисичка-аллигатор Бартона, щитонос Бартона // Рыбы в заповедниках России: В 2-х т. - Т. 2. Морские рыбы. - М.: Тов-во науч. изд. КМК, 2013. - С. 258-260.

664. Карамушко О.В., Решетников Ю.С. 97. Pallasina aix Starks, 1896 - северная полосатая паллазина, игловидная лисичка // Рыбы в заповедниках России: В 2-х т. - Т. 2. Морские рыбы. - М.: Тов-во науч. изд. КМК, 2013. - С. 272-274. 
665. Карамушко О.В., Решетников Ю.С. 98. Pallasina barbata (Steindachner, 1876) - южная полосата паллазина, бородатая лисичка // Рыбы в заповедниках России: В 2-х т. - Т. 2. Морские рыбы. - М.: Тов-во науч. изд. КМК, 2013. - С. 274-277.

666. Карамуико O.В., Решетников Ю.C. 147. Leptoclinus maculatus (Fries, 1838) - пятнистый лептоклин // Рыбы в заповедниках России: В 2-х т. - Т. 2. Морские рыбы. - М.: Тов-во науч. изд. КМК, 2013. C. 391-394.

667. Карамушко О.В., Христиансен Й.Ш. Новые данные по ихтиофауне прибрежных вод Северо-Восточной Гренландии // Глобальные климатические процессы и их влияние на экосистемы арктических и субарктических регионов: Тез. докл. Междунар. науч. конф. (г. Мурманск, 9-11 ноября 2011 г.). - Апатиты: Изд-во КНЦ РАН, 2011. - C. 83-84.

668. Кудрявиева О.Ю. Некоторые аспекты биологии европейского керчака Myoxocephalus scorpius (L.) (Cottodae) в Кольском заливе Баренцева моря // Вестн. Мурм. гос. техн. ун-та. - 2012. - Т. 15, № 4. C. 766-775.

669. Кудрявиева О.Ю. Обзор ихтиофауны района Земли ФранцаИосифа // Тр. Кольского науч. центра РАН. - 2014. - Т. 4(23). - Сер. Океанология. - Вып. 2. - С. 222-251.

670. Кудрявцева О.Ю. Структура прибрежных сообществ молоди рыб в губах Дальнезеленецкая и Ярнышная Баренцева моря // Арктическое морское природопользование в XXI веке - современный баланс научных традиций и инноваций (к 80-летию ММБИ КНЦ РАН): Тез. докл. Междунар. науч. конф. (г. Мурманск, 1-3 апреля 2015 г.). Апатиты: Изд-во КНЦ РАН, 2015. - С. 119-121.

671. Лужняк В.А., Васильева Е.Д., Демченко В.А. Таксономическое разнообразие ихтиофауны бассейна Азовского моря в современный период // Комплексные исследования больших морских экосистем России. - Апатиты: Изд-во КНЦ РАН, 2011. - С. 398-409.

672. Матишов Г.Г., Иванов В.П., Балькин П.А. Введение // Белорыбица и кумжа Каспийского бассейна. - Ростов н/Д.: Изд-во ЮНЦ РАН, 2010. - С. 7-8.

673. Матишов Г.Г., Иванов В.П., Бальккин П.А. Промысловое значение белорыбицы и кумжи // Белорыбица и кумжа Каспийского бассейна. - Ростов н/Д.: Изд-во ЮНЦ РАН, 2010. - С. 17-18.

674. Матишов Г.Г., Иванов В.П., Балькин П.А. Заключение // Белорыбица и кумжа Каспийского бассейна. - Ростов н/Д.: Изд-во ЮНЦ РАН, 2010. - С. 73-75. 
675. Попова О.А., Карамушко О.В. 22. Eleginus nawaga (Koelreuter, 1770) - атлантическая навага, навага // Рыбы в заповедниках России: В 2-х т. - Т. 2. Морские рыбы. - М.: Тов-во науч. изд. КМК, 2013. C. $78-80$.

676. Попова O.A., Карамушко O.B. 30. Lophius piscatorius Linnaeus, 1758 - морской черт // Рыбы в заповедниках России: В 2-х т. - Т. 2. Морские рыбы. - М.: Тов-во науч. изд. КМК, 2013. - С. 100-102.

677. Представители ихтиофауны в прибрежных зонах губ Ярнышная и Зеленецкая в летний период в 2013 и 2014 гг. / О.В. Бондарев, К.И. Ким, С.С. Малавенда, О.Ю. Кудрявиева // Проблемы Арктического региона: Пятнадцатая Междунар. науч. конф. студентов и аспирантов (г. Мурманск, 14 мая 2015 г.): Тез. докл. - Ростов н/Д.: Изд-во ЮНЦ PAH, 2015. - C. 70-71. - URL: http://www.mmbi.info/publikatsii/n52/

678. Расхожева E.B. Климатические изменения, промысел и продукционные процессы в популяции сайки Boreigadus saida (Lepechin, 1773) Баренцева моря // Глобальные климатические процессы и их влияние на экосистемы арктических и субарктических регионов: Тез. докл. Междунар. науч. конф. (г. Мурманск, 9-11 ноября 2011 г.). - Апатиты: Изд-во КНЦ РАН, 2011. - С. 162-164.

679. Расхожева E.B. Рост и продукция сайки в Карском море // Современные проблемы экологии и природопользования: Матер. регион. науч.-практ. конф., посвященной 15-летию со дня основания кафедры биоэкологии, Мурманск, 27-28 февраля 2014 г. - Мурманск: Изд-во Мурм. гос. техн. ун-та, 2014. - С. 172-177.

680. Расхожева E.B. Продукционные процессы и параметры жизненного цикла в популяции сайки Баренцева моря // Арктическое морское природопользование в XXI веке - современный баланс научных традиций и инноваций (к 80-летию ММБИ КНЦ РАН): Тез. докл. Междунар. науч. конф. (г. Мурманск, 1-3 апреля 2015 г.). Апатиты: Изд-во КНЦ РАН, 2015. - С. 205-207.

681. Расхожева E.B. Динамика Р/В-коэффициента и параметры жизненного цикла в популяции сайки Boreogadus saida (Lepechin, 1774) Баренцева моря // Функционирование и динамика водных экосистем в условиях климатических изменений и антропогенных воздействий: Матер. 5-й Междунар. конф., посвященной памяти выдающегося гидробиолога Г.Г. Винберга (12-17 октября 2015 г., г. Санкт-Петербург, Россия). - СПб.: Лема, 2015. - С. 219-220.

682. Решетников Ю.С., Карамушко О.В. 3. Squalus suckleyi (Girard, 1855) - колючая тихоокеанская акула // Рыбы в заповедниках России: В 2-х т. - Т. 2. Морские рыбы. - М.: Тов-во науч. изд. КМК, 2013. - C. 27-30. 
683. Решетников Ю.С., Карамушко О.В. 63. Gymnocanthus tricuspis (Reinhardt, 1830) - арктический шлемоносец // Рыбы в заповедниках России: В 2-х т. - Т. 2. Морские рыбы. - М.: Тов-во науч. изд. КМК, 2013. - C. 186-188.

684. Решетников Ю.С., Карамушко О.В. 93. Brachyopsis segaliensis (Tilesius, 1809) - длиннорылая лисичка, сахалинская лисичка // Рыбы в заповедниках России: В 2-х т. - Т. 2. Морские рыбы. - М.: Тов-во науч. изд. КМК, 2013. - С. 261-263.

685. Решетников Ю.С., Карамуико О.B. 99. Percis japonica (Pallas, 1769) - японская лисичка // Рыбы в заповедниках России: В 2-х т. Т. 2. Морские рыбы. - М.: Тов-во науч. изд. КМК, 2013. - С. 277-280.

686. Решетников Ю.С., Карамушко О.В. 100. Podothecus accipenserinus (Tilesius, 1813) - осетровидная лисичка // Рыбы в заповедниках России: В 2-х т. - Т. 2. Морские рыбы. М.: Тов-во науч. изд. КМК, 2013. C. $280-282$.

687. Решетников Ю.С., Карамушко О.В. 101. Sarritor frenatus (Gilbert, 1896) - тонкохвостая лисичка // Рыбы в заповедниках России: В 2-х т. - Т. 2. Морские рыбы. - М.: Тов-во науч. изд. КМК, 2013. C. $283-285$.

688. Решетников Ю.С., Карамушко О.В. 102. Sarritor leptorhynchus (Gilbert, 1896) - тонкокрылая лисичка // Рыбы в заповедниках России: В 2-х т. - Т. 2. Морские рыбы. М.: Тов-во науч. изд. КМК, 2013. C. $286-288$.

689. Решетников Ю.С., Карамушко О.В. 105. Cyclopterus lumpus (Linnaeus, 1758) - пинагор // Рыбы в заповедниках России: В 2-х т. Т. 2. Морские рыбы. - М.: Тов-во науч. изд. КМК, 2013. - С. 295-298.

690. Решетников Ю.С., Карамушко О.В. 126. Gymnelus retrodorsalis Le Danois, 1913 - тонкорукий (тонкопёрый) гимнелис // Рыбы в заповедниках России: В 2-х т. - Т. 2. Морские рыбы. - М.: Тов-во науч. изд. КМК, 2013. - С. 345-347.

691. Решетников Ю.С., Карамушко О.В. 128. Lycodes beringi Andriashev, 1935 - ликод Беринга // Рыбы в заповедниках России: В 2-х т. Т. 2. Морские рыбы. - М.: Тов-во науч. изд. КМК, 2013. - С. 349-351.

692. Решетников Ю.С., Карамушко О.В. 140. Anisarchus medius (Reinhardt, 1837) - ильный люмпен // Рыбы в заповедниках России: В 2-х т. - Т. 2. Морские рыбы. - М.: Тов-во науч. изд. КМК, 2013. C. $376-378$.

693. Результаты ихтиологических исследований устьевого взморья Дона / Г.Г. Матишов, Е.Н. Пономарева, В.А. Лужняк, А.В. Стариев. Ростов н/Д.: Изд-во ЮНЦ РАН, 2014. - 160 с. 
694. Салмова Н.А., Журавлева Н.Г. Влияние абиотических экологических факторов на иммунитет рыб [Электронный ресурс] // Наука и образование - 2013: Матер. Междунар. науч.-техн. конф., Мурманск, 4-11 марта 2013 г. - Электрон. текст. дан. (220 Мб). Мурманск: Изд-во Мурм. гос. техн. ун-та, 2013. - С. 1042-1045. 1 электрон. опт. диск (CD-ROM). - Систем. требования: PC не ниже класса Pentium II; $128 \mathrm{Mb}$ RAM; свободное место на HDD $130 \mathrm{Mb}$; дисковод CD-ROM 2-х и выше. - Электрон. текст подг. ФГБОУ ВПО «МГТУ». - № гос. регистрации 0321301202.

695. Светочева О.Н., Эриксен Е. Морфологическая характеристика отолитов некоторых донных рыб Баренцева моря // Вестн. Кольского науч. центра РАН. - 2013. - № 4(15). - С. 91-104.

696. Селифонова Ж.П. Мониторинг ихтиопланктона в Новороссийском порту Черного моря // Современное состояние и технологии мониторинга аридных и семиаридных экосистем юга России. - Ростов н/Д.: Изд-во ЮНЦ РАН, 2010. - С. 258-264.

697. Смирнова E.В. Разнообразие непромысловых видов рыб в северной части Баренцева моря в различные климатические периоды // Глобальные климатические процессы и их влияние на экосистемы арктических и субарктических регионов: Тез. докл. Междунар. науч. конф. (г. Мурманск, 9-11 ноября 2011 г.). - Апатиты: Изд-во КНЦ PAH, 2011. - C. 180.

698. Смирнова E.B. Сезонная и межгодовая динамика соотношений различных видов рыб в уловах в 1999-2010 гг. // Материалы XXIX конференции молодых ученых Мурманского морского биологического института, посвященной 140-летию со дня рождения Г.А. Клюге, «Морские исследования экосистем европейской Арктики» (г. Мурманск, май 2011 г.). - Мурманск: Изд. ММБИ КНЦ РАН, 2011. - С. 190-191.

699. Смирнова E.B. Особенности распространения чернобрюхого липариса Liparis fabricii Krøyer, 1847 в Баренцевом море // Материалы $\mathrm{XXX}$ юбилейной конференции молодых ученых Мурманского морского биологического института, посвященной 150 -летию со дня рождения Н.М. Книповича, «Проблемы океанографии, биологии и освоения биоресурсов морей российской Арктики» (г. Мурманск, май 2012). - Мурманск: Изд. ММБИ КНЦ РАН, 2012. - С. 173-175.

700. Смирнова E.B. Анализ распределения видов рода Triglops Reinhardt, 1830 в Баренцевом и Карском морях // Эколого-эволюционные исследования морских организмов и экосистем: Матер. XIV Междунар. науч. конф. студентов и аспирантов «Проблемы Арктического региона» (г. Мурманск, май 2014 г.). Т. І. Форум молодых ученых, посвященный 110-летию со дня рождения Ю.И. Полянского (XXXII конференция молодых ученых ММБИ). - Мурманск: Изд. ММБИ КНЦ РАН, 2014. C. $144-150$. 
701. Смирнова E.В. Анализ распределения некоторых видов рода Lycodes (Zoarcidae) в Баренцевом и Карском морях // Арктическое морское природопользование в XXI веке - современный баланс научных традиций и инноваций (к 80-летию ММБИ КНЦ РАН): Тез. докл. Междунар. науч. конф. (г. Мурманск, 1-3 апреля 2015 г.). Апатиты: Изд-во КНЦ РАН, 2015. - С. 220-221.

702. Смирнова Е.В., Карамушко О.В. Факторный анализ распространения чернобрюхого липариса Liparis cf. fabricii Krøyer, 1847 в Карском море // Современные проблемы экологии и природопользования: Матер. регион. науч.-практ. конф., посвященной 15-летию со дня основания кафедры биоэкологии, Мурманск, 27-28 февраля 2014 г. Мурманск: Изд-во Мурм. гос. техн. ун-та, 2014. - С. 221-227.

703. Смирнова E.В., Карамушко О.В. Пространственное распределение и некоторые черты биологии чернобрюхого липариса Liparis cf. fabricii Krøyer, 1847 в Карском море // Вестн. Кольского науч. центра РАН. - 2015. - № 1(20). - С. 78-84.

704. Современные исследования ихтиофауны Баренцева моря и сопредельных вод / О.В. Карамушко, Н.Г. Журавлева, Л.И. Карамушко, О.Ю. Кудрявиева, Е.В. Расхожева, Е.В. Смирнова // Морские экосистемы и сообщества в условиях современных климатических изменений. - СПб.: Реноме, 2014. - С. 223-243.

705. Филогеография тихоокеанской сельди (Clupea pallasii) некоторых морей Евразии / B.В. Горбачев, Л.А. Черноиванова, П.Н. Панфилова, И.К. Трофимов, Р.Л. Батанов, В.Г. Чикилев, А.А. Бонк, И.О. Нехаев, Л.Л. Солвенчук, А.В. Вакатов // Генетика. 2012. - T. 48(9). - C. 1091-1097.

706. Чернова Н.В., Смирнова Е.В., Расхожева Е.В. О первом нахождении гренландской полярной акулы Somniosus microcephalus (Somniosidae) в сибирской Арктике с замечаниями о ее распространении и биологии // Вопросы ихтиологии. - 2015. - Т. 55, № 6. - С. 665-674.

707. Arctic skate Amblyraja hyperborea preys on remarkably large glacial eelpouts Lycodes frigidus / I. Birkjedal, J.Sh. Christiansen, O.V. Karamushko, G. Langhelle, A. Lynghammar // J. Fish Biol. - 2015. Vol. 86, iss. 1. - P. 360-364.

708. Atlantic fishes in the Chukchi Borderland / C.W. Mecklenburg, I. Byrkjedal, O.V. Karamushko, P.R. Møller // Marine Biodiversity. - 2014. Vol. 44. - P. 127-150. - Doi: 10.1007/s12526-013-0192-1

709. Christiansen J.S., Mecklenburg C.W., Karamushko O.V. Arctic marine fishes and their fisheries in light of global change // Global Change Biol. - 2013. - P. 1-8. - Doi: 10.1111/gcb.12395. 
710. Dvoretsky A.G., Dvoretsky V.G. Commercial fish and shellfish in the Barents Sea: Have introduced crab species affected the population trajectories of commercial fish? // Reviews in Fish Biology and Fisheries. 2015. - Vol. 25, № 2. - P. 297-322. - Doi: 10.1007/s11160-015-9382-1. URL: http://link.springer.com/article/10.1007/s11160-015-9382-1

711. Fishes / J.S. Christiansen, J.D. Reist, R.J. Brown, V.A. Brykov, G. Christensen, K. Christoffersen, P. Cott, P. Crane, J.B. Dempson, M. Docker, K. Dunmall, A. Finstad, V.F. Gallucci, J. Hammar, L.N. Harris, J. Heino, E. Ivanov, O.V. Karamushko, A. Kirillov, A. Kucheryavyy, H. Lehtonen, A. Lynghammar, C.W. Mecklenburg, P.D.R. Moller, T. Mustonen, A.G. Oleinik, M. Power, Y.S. Reshetnikov, V.I. Romanov, O.-T. Sandlund, C.D. Sawatzky, M. Svenning, K.H. Swanson, F.J. Wrona // Arctic biodiversity assessment. Status and trends in Arctic biodiversity. Conservation of Arctic flora and fauna, Akureyri (CAFF2013). - Denmark: Narayana Press, 2013. - P. 192-245.

712. Karamushko L.I. Growth, production, metabolism and adaptations of high-latitude marine fish // Doklady Biol. Sci. - 2014. - Vol. 455. P. 116-118.

713. Karamushko L.I., Christiansen J.S. Bioenergetic adaptations in polar cod Boreogadus saida (Lepechin, 1774) // Dynamics of sub-Arctic marine ecosystems: Abstr. book ESSAS Annual Science Meeting (Copenhagen, Denmark, 7-9 April 2014). - Copenhagen, 2014. - P. 45.

714. Karamushko O.V. Structure of ichthyofauna in the Arctic seas off Russia // Berichte zur Polarforschung. - 2012. № 640. - P. 129-136.

715. List of marine and diadromous fishes of the arctic region: working draft with common names and zoogeographic characterizations for the circumpolar biodiversity monitoring program / C.W. Mecklenburg, I. Byrkjedal, J.S. Christiansen, O.V. Karamushko, A. Lynghammar, P.R. Møller. Akureyri: CAFF, 2013. - 40 p. - URL: http://www.abds.is/publications/ view_category/129-marine-ecosystems

716. Marine fishes of the Arctic. Arctic report card / F.J. Mueter, J.D. Reist, A.R. Majewski, C.D. Sawatzky, J.S. Christiansen, K.J. Hedges, B.W. Coad, O.V. Karamushko, R.R. Lauth, A. Lynghammar, S.A. MacPhee, C.W. Mecklenburg // Update for 2013. - Washington: NOAA, 2013. P. 58-72. - URL: http://www.arctic.noaa.gov/report13/marine_fish.html

717. Physiological responses to petroleum-related compounds in the Arctic key species polar cod (Boreogadus saida) / J. Nahrgang, S. Meier, M. Frantzen, J.S. Christiansen, L.I. Karamushko, I. Wasbotten // Comparative Biochemistry and Physiology. Part A. Molecular \& Integrative Physiology. 2012. - Vol. 163. - P. 52-53. 
718. Physiological responses to petroleum-related compounds in the Arctic key species polar cod (Boreogadus saida) / J. Nahrgang, S. Meier, M. Frantzen, J.S. Christiansen, L.I. Karamushko, I. Wasbotten, J. Berge // Cellular and molecular mechanisms for physiological adaptation to multiple stress: $28^{\text {th }}$ ESCPB Congress (2-5 September 2012, Bilbao, Basque Country (Spain). - Bilbao, 2012. - P. 23.

719. Physiological responses to dietary crude oil in the Arctic key species polar cod (Boreogadus saida) / J. Nahrgang, S. Meier, M. Frantzen, A. Mackee, J.S. Christiansen, L.I. Karamushko, I. Halvorsen, J. Berge // $4^{\text {th }}$ Norwegian Environmental Toxicology Symposium «Emerging challenges and threats in the Arctic» (16-18 October 2012, Tromsø, Norway). Tromsø, 2012. - P. 45.

720. Physiological responses to petroleum-related compounds in the Arctic key species polar cod (Boreogadus saida) / J. Nahrgang, S. Meier, M. Frantzen, J.S. Christiansen, L.I. Karamushko, I. Wasbotten, J. Berge // $23^{\text {rd }}$ SETAC Europe (Society of Environmental Toxicology and Chemistry) Annual Meeting, 12-16 May 2013, Glasgow, Scotland. - Glasgow, 2013. - P. 17.

721. Physiological responses to dietary crude oil in the Arctic key species polar cod (Boreogadus saida) / J. Nahrgang, S. Meier, M. Frantzen, A. Mackee, J.S. Christiansen, L.I. Karamushko, I. Halvorsen, J. Berge // Pollutant Responses in Marine Organisms (PRIMO): Abstr. for the $17^{\text {th }}$ Congress, 5-8 May 2013, Faro, Portugal. - Faro, 2013. - P. 39.

722. Physiological responses to dietary crude oil in the arctic key species polar cod (Boreogadus saida) / J. Nahrgang, M. Bender, S. Meier, M. Frantzen, J.S. Christiansen, L.I. Karamushko, I. Wasbotten, J. Berge // Polar cod \& Petroleum: Abstr. book Sci. Meeting (Copenhagen, Denmark, 10 April 2014). - Copenhagen, 2014. - P. 14.

723. Raskhozheva E.V. Growth and production of polar cod Boreogadus saida (Lepechin) in the Barents and Kara seas // Dynamics of sub-Arctic Marine Ecosystems: Abstr. book ESSAS Annual Sci. Meeting (Copenhagen, Denmark, 7-9 April 2014). - Copenhagen, 2014. - P. 52.

724. Spatial distribution and abundance of Arctogadus glacialis and Boreogadus saida in NE Greenland / M.L. Madsen, R. Primicerio, M. Greenacre, K. Proebel, S.-E. Fevolden, O.V. Karamushko, J.S. Christiansen // Dynamics of sub-Arctic Marine Ecosystems: Abstr. book ESSAS Annual Sci. Meeting (Copenhagen, Denmark, 7-9 April 2014). - Copenhagen, 2014. - P. 51-52.

725. Species richness and distribution of chondrichthyan fishes in the Arctic Ocean and adjacent seas / A. Lynghammar, J.S. Christiansen, C.W. Mecklenburg, O.V. Karamushko, P.R. Møller, V.F. Gallucci // Biodeversity. - 2013. - Vol. 14, iss. 1. - P. 57-66. - Doi: org./10.1080/ 14888386.2012.706198. - URL: http://www.tandfonline.com/toc/tbid20/current 
726. Svetocheva O., Eriksen E., Haug T. Barents Sea Ammodytidae and their ecological significance for the top predators during summer feeding // Climate change and effects on the Barents Sea marine living resources: The $15^{\text {th }}$ Russ.-Norw. Symp. (Svalbard, Norway, 6-9 September 2011). - Longyearbyen, 2011. - P. 181-188. - Doi: 10.13140/2.1.4381.0245

727. The marine fishes of Jan Mayen Island, NE Atlantic - past and present / R.M. Weinerroither, K.H. Nedreaas, F. Uiblein, J.S. Christiansen, I. Byrkjedal, O. Karamushko // Marine Biodiversity. - 2011. - Vol. 41, № 3. - P. 395-411.

\section{Аквакультура}

728. Биотехнология и экономика аквакультуры и первичной переработки морских макрофитов на побережье Баренцева моря / Г.М. Воскобойников, И.В. Голяк, Ю.Ф. Куранов, М.В. Макаров // Арктическое морское природопользование в XXI веке - современный баланс научных традиций и инноваций (к 80-летию ММБИ КНЦ РАН): Тез. докл. Междунар. науч. конф. (г. Мурманск, 1-3 апреля 2015 г.). Апатиты: Изд-во КНЦ РАН, 2015. - С. 34-35.

729. Воскобойников Г.М. Санитарная аквакультура: от гипотезы до демонстрационного проекта // Морские прибрежные экосистемы, водоросли, беспозвоночные и продукты их переработки: Матер. IV Междунар. конф. - Южно-Сахалинск: Изд. СахНИРО, 2011. - С. 170-171.

730. Воскобойников Г.М., Зубова Е.Ю. Морские водоросли в санитарной аквакультуре: теория и практика // Актуальные проблемы современной альгологии: Тез докл. IV Междунар. конф. (23-25 мая 2012 г., г. Киев, Украина). - Киев: Изд-во Ин-та ботаники им. Н.Г. Холодного НАН Украины, 2012. - С. 62-63.

731. Журавлева Н.Г. Причины торможения товарного рыбоводства на европейском Севере // Задачи государства в становлении морского и пресноводного рыбоводства: опыт, ошибки и перспективы импортозамещения: Сб. докл. расширенного заседания Президиума ЮНЦ РАН (Ростовская область, с. Кагальник, 10 июня 2015 г.). Ростов н/Д.: Изд-во ЮНЦ РАН, 2015. - С. 47-57.

732. Журавлева Н.Г., Ларина Т.М. Краткая характеристика сведений о критических периодах у эмбрионов и личинок рыб [Электронный ресурс] // Наука и образование - 2011: Матер. Междунар. науч.-техн. конф. - Электрон. текст. дан. (30 Мб). - Мурманск: Изд-во Мурм. гос. техн. ун-та, 2011. - С. 597-602. - 1 электрон. опт. диск (CDROM). - Систем. требования: PC не ниже класса Pentium II; $128 \mathrm{Mb}$ 
RAM; свободное место на HDD 30 Mб; дисковод CD-ROM 2-х и выше. Загл. с экрана. - Электрон. текст подг. ФГБОУ ВПО «МГТУ». № гос. регистрации 0321100504 .

733. Кабанова Н.А., Журавлева Н.Г. Марикультура - перспективное направление рационального ведения рыбного хозяйства [Электронный pecyрс] // Охрана окружающей среды и здоровья человека в Российской Федерации и странах Евросоюза: Матер. Междунар. науч.-практ. конф., Мурманск, 31 окт. 2014 г. - Электрон. текст. дан. (5.15 Мб). - Мурманск: Изд-во Мурм. гос. техн. ун-та, 2014. - С. 28-34. - 1 электрон. опт. диск (CD-ROM). - Систем. требования: PC не ниже класса Pentium II; 128 Mb RAM; Windows 9x-Windows 8; свободное место на HDD 131 Мб; дисковод CD-ROM 2-х и выше. - Загл. с экрана. - Электрон. текст подг. ФГБОУ ВПО «МГТУ».

734. К вопросу о возможности использования фукусовых водорослей в санитарной аквакультуре / Г.М. Воскобойников, Е.Ю. Зубова, Н.Н. Мишина, Д.В. Пуговкин, И.В. Рыюжик // Глобальные климатические процессы и их влияние на экосистемы арктических и субарктических регионов: Тез. докл. Междунар. науч. конф. (г. Мурманск, 9-11 ноября 2011 г.). - Апатиты: Изд-во КНЦ РАН, 2011. - С. 18-19.

735. Ларина Т.М., Журавлева Н.Г. Некоторые практические рекомендации для выращивания молоди трески [Электронный ресурс] // Наука и образование - 2011: Матер. Междунар. науч.-техн. конф. Электрон. текст. дан. (30 Мб). - Мурманск: Изд-во Мурм. гос. техн. ун-та, 2011. - С. 614-616. - 1 электрон. опт. диск (CD-ROM). - Систем. требования: PC не ниже класса Pentium II; 128 Mb RAM; свободное место на HDD 30 Мб; дисковод CD-ROM 2-х и выше; - Загл. с экрана. Электрон. текст подг. ФГБОУ ВПО «МГТУ». - № гос. регистрации 0321100504.

736. Ларина Т.М., Журавлева Н.Г. Причины возникновения отклонений от нормы при выращивании личинок рыб // Наука и образование - 2012: Матер. Междунар. науч.-техн. конф., Мурманск, 2-6 апреля 2012 г. - Электрон. текст. дан. (30 Мб). - Мурманск: Изд-во Мурм. гос. техн. ун-та, 2012. С. 392-394. - 1 электрон. опт. диск (CDROM). - Систем. требования: PC не ниже класса Pentium II; $128 \mathrm{Mb}$ RAM; свободное место на HDD 130 Мб; дисковод CD-ROM 2-х и выше. - Загл. с экрана. - Электрон. текст подг. ФГБОУ ВПО «МГТУ». № гос. регистрации 0321201101 .

737. Матишов Г.Г., Дженюк С.Л. Как развивать арктическую науку в современных условиях // Задачи государства в становлении морского и пресноводного рыбоводства: опыт, ошибки и перспективы импортозамещения: Сб. докл. расширенного заседания Президиума ЮНЦ РАН (Ростовская область, с. Кагальник, 10 июня 2015 г.). Ростов н/Д.: Изд-во ЮНЦ РАН, 2015. - С. 105-118. 
738. Матишов Г., Балькин П., Пономарева Е. Рыболовство и аквакультура России // Наука в России. - 2012. - № 1. - С. 64-71.

739. Матишов Г.Г., Балыкин П.А., Пономарева Е.Н. Рыболовство и аквакультура России // Вестн. РАН. - 2012. - Т. 82, № 1. - С. 35-49.

740. Матишов Г.Г., Пономарева Е.Н., Белая М.М. Сохранение генетического разнообразия рыб методами низкотемпературного консервирования // Рыбное хозяйство. - 2012. - № 3. - С. 59-62.

741. Муравейко А.В., Емелина А.В. Предпосылки развития аквакультуры на Кольском полуострове // Рыбное хозяйство. - 2015. № 3. - С. 89-93.

742. Новые биотехнологии и технические средства для выращивания осетровых рыб в установках замкнутого водообеспечения / Г.Г. Матишов, Е.Н. Пономарева, Р.Е. Вербицкий, М.В. Коваленко, А.А. Бирюков // Наукоемкие технологии дл инновационной индустрии южного макрорегиона. - Ростов н/Д.: Изд-во ЮНЦ РАН, 2011. - С. 9-19.

743. Опыт создания криобанка водорослей-макрофитов Баренцева моря / Г.М. Воскобойников, И.В. Голяк, Е.Ю. Зубова, Е.О. Кудрявиева // Вестн. Южного науч. центра РАН. - 2015. - Т. 11, № 4. - С. 93-95.

744. Причины деформаций нотохорда молоди атлантической трески при культивировании в Северной Европе / Н.Г. Журавлева, Г.Г. Матишов, O. Оттесен, T.M. Ларина // Международная рыбохозяйственная деятельность Российской Федерации на современном этапе. - М.: Изд-во ВНИРО, 2010. - С. 181-186 (Тр. ВНИРО. Т. 149).

745. Практическая аквакультура (разработки ЮНЦ РАН и ММБИ) / Г.Г. Матишов, Е.Н. Пономарева, Н.Г. Журавлева, В.А. Григорьев, B.A. Лужняк. - Ростов н/Д.: Изд-во ЮНЦ РАН, 2011. - 284 с.

746. Салмова Н.А., Журавлева Н.Г. Продукция аквакультуры как источник пищевого белка // Наука и образование - 2011: Матер. Междунар. науч.-техн. конф. - Электрон. текст. дан. (30 Мб). Мурманск: Изд-во Мурм. гос. техн. ун-та, 2011. - С. 647-651. 1 электрон. опт. диск (CD-ROM). - Систем. требования: PC не ниже класса Pentium II; $128 \mathrm{Mb}$ RAM; свободное место на HDD 30 Мб; дисковод CD-ROM 2-х и выше; - Загл. с экрана. - Электрон. текст подг. ФГБОУ ВПО «МГТУ». - № гос. регистрации 0321100504.

747. Салмова Н.А., Журавлева Н.Г. Гистологическое строение печени и поджелудочной железы личинок трески (Gadus morhua L.) в условиях искусственного содержания // Биоресурсы и аквакультура: Тез. докл. Школы молодых ученых по морской биологии (Мурманск, 28-29 февраля 2012 г.). - Мурманск: Изд-во Мурм. гос. техн. ун-та, 2012. - C. 37-41. 
748. Салмова Н.А., Журавлева Н.Г. Морфологическое строение печени и поджелудочной железы молоди трески (Gadus morhua L.) в условиях искусственного выращивания // Вестн. Мурм. гос. техн. ун-та. - 2012. - Т. 15, № 3. - С. 551-558.

749. Салмова Н.А., Журавлева Н.Г. Рациональное управление природопользованием в марикультуре // Экологическая безопасность приморских регионов (порты, берегозащита, рекреация, марикультура): Матер. Междунар. науч. конф., посвященной 150-летию Н.М. Книповича (Ростов-на-Дону, 5-8 июня 2012 г.). - Ростов н/Д.: Изд-во ЮНЦ РАН, 2012. - С. 213-216.

750. Салмова Н.А., Журавлева Н.Г. Особенности гистологической структуры тимуса мальков атлантической трески в условиях марикультуры // 2013 год - год охраны окружающей среды в России: Тез. докл. конф. молодых ученых (Мурманск, 12-13 февраля 2013 г.). Мурманск: Изд-во Мурм. гос. техн. ун-та, 2013. - С. 59-65.

751. Салмова Н.А., Журавлева Н.Г., Щепак Л.В. Аквакультура перспективное направление рационального природопользования // Современные проблемы экологии и природопользования: Матер. регион. науч.-практ. конф., посвященной 15-летию со дня основания кафедры биоэкологии, Мурманск, 27-28 февраля 2014 г. - Мурманск: Изд-во Мурм. гос. техн. ун-та, 2014. С. 235-238.

752. Санитарная аквакультура: от гипотезы до демонстрационного проекта / Г.М. Воскобойников, М.В. Макаров, И.В. Рыюсик, Д.В. Пуговкин // Водоросли: проблемы таксономии, экологии и использование в мониторинге: Матер. докл. III Междунар. науч.-практ. конф. - Ярославль: Изд. Ин-та биол. внутр. вод им. И.Д. Папанина, 2014. - С. 213-214.

753. Федотова Л.В., Оттесен О., Журавлева Н.Г. Деформации личинок радужного губана (Labrus bergylta) при различных условиях инкубации икры // Современные эколого-биологические и химические исследования, техника и технология производств: Матер. Междунар. науч.-практ. конф., Мурманск, 7 апреля 2015 г.: В 2-х ч. - Мурманск: Изд-во Мурм. гос. техн. ун-та, 2015. - Ч. 1. - С. 286-290.

754. Щепак Л.В., Журавлева Н.Г. Проблемы заражения лосося морскими вшами и ее решение в рамках устойчивого развития [Электронный ресурс] // Наука и образование - 2013: Матер. Междунар. науч.-техн. конф., Мурманск, 4-11 марта 2013 г. - Электрон. текст. дан. (220 Мб). - Мурманск: Изд-во Мурм. гос. техн. ун-та, 2013. C. 1064-1066. - 1 электрон. опт. диск (CD-ROM). - Систем. требования: PC не ниже класса Pentium II; $128 \mathrm{Mb}$ RAM; свободное место на HDD $130 \mathrm{Mb}$; дисковод CD-ROM 2-х и выше. - Загл. с экрана. - Электрон. текст подг. ФГБОУ ВПО «МГТУ». - № гос. регистрации 0321301202. 
755. Щепак Л.В., Журавлева Н.Г., Оттесен О. Эффекты температуры и солености на оплодотворенную икру радужного губана (Labrus bergylta) при инкубировании // Вестн. Камчатского гос. техн. ун-та. - 2012. - № 22. - С. 92-97.

756. Щепак Л.В., Журавлева Н.Г., Оттесен О. Современное состояние марикультуры лосося и проблемы заражения лосося паразитами Lepeophtheirus salmonis // 2013 год - год охраны окружающей среды в России: Тез. докл. конф. молодых ученых (Мурманск, 12-13 февраля 2013 г.). - Мурманск: Изд-во Мурм. гос. техн. ун-та, 2013. - С. 68-89.

757. Щепак Л.В., Журавлева Н.Г., Оттесен О. Ballan wrasse как важный вид для аквакультуры морских холодноводных видов [Электронный ресурс] // Наука и образование - 2013: Матер. Междунар. науч.-техн. конф., Мурманск, 4-11 марта 2013 г. - Электрон. текст. дан. (220 Мб). - Мурманск: Изд-во Мурм. гос. техн. ун-та, 2013. C. 1060-1063. - 1 электрон. опт. диск (CD-ROM). - Систем. требования: PC не ниже класса Pentium II; $128 \mathrm{Mb}$ RAM; свободное место на HDD $130 \mathrm{Mb}$; дисковод CD-ROM 2-х и выше. - Электрон. текст подг. ФГБОУ ВПО «МГТУ». - № гос. регистрации 0321301202.

758. Matishov G.G., Ponomareva E.N. Prospects for biotechnology development of Aquaculture in Southern Russia // World Aquaculture. 2015. - Vol. 46, № 4 (December). - P. 64-65.

759. Salmova N., Zhuravleva N. Mariculture as an element of environmental management [Электронный ресурс] // Наука и образование 2014: Матер. Междунар. науч.-техн. конф., Мурманск, 24-28 марта 2014 г. - Электрон. текст. дан. - Мурманск: Изд-во Мурм. гос. техн. ун-та, 2014. - C. 1007-1012. - 1 электрон. опт. диск (CD-ROM). Систем. требования: PC не ниже класса Pentium II; 128 Mb PAM; свободное место на HDD $100 \mathrm{Mb}$; Adobe Acrobat Reader; дисковод CDROM 2-х и выше. - Загл. с экрана. - Электрон. текст подг. ФГБОУ ВПО «МГТУ». - № гос. регистрации 0321401155.

760. Shchepak L.V., Zhuravleva N.G. Salmon lice (Lepeophtheirus salmonis) problem and its solution in the framework of sustainable development [Электронный ресурс] // Наука и образование - 2014: Матер. Междунар. науч.-техн. конф., Мурманск, 24-28 марта 2014 г. Электрон. текст. дан. - Мурманск: Изд-во Мурм. гос. техн. ун-та, 2014. C. 1013-1016. - 1 электрон. опт. диск (CD-ROM). - Систем. требования: PC не ниже класса Pentium II; $128 \mathrm{Mb}$ PAM; свободное место на HDD $100 \mathrm{Mb}$; Adobe Acrobat Reader; дисковод CD-ROM 2-х и выше. - Загл. с экрана. - Электрон. текст подг. ФГБОУ ВПО «МГТУ». - № гос. регистрации 0321401155. 


\section{энтомология}

761. Абдурахманов Г.М., Набоженко М.В. Определитель и каталог жуков-чернотелок (Coleoptera: Tenebrionidae s. str.) Кавказа и юга европейской части России. - М.: Тов-во науч. изд. КМК, 2011. - 361 с.

762. Кирейчук А.Г., Набоженко М.В., Нель А. Первый мезозойский представитель подсем. Tenebrioninae (Coleoptera: Tenebrionidae) из нижнего мела Исяня (Китай, пров. Ляонин) // Энтомол. обозрение. 2011. - Т. 90, вып. 3. - С. 548-552.

763. Лебедева Н.В., Таскаева А.А., Коулсон С.Дж. Разнообразие ногохвосток (Collembola) в гнездах бургомистра Larus hyperboreus 1. (арх. Шпицберген) // Комплексные исследования природы Шпицбергена: Матер. Междунар. науч. конф. (Мурманск, 1-3 ноября 2012 г.). Вып. 11. - М.: ГЕОС, 2012. - С. 146-149.

764. Марахонич A.B., Набоженко М.В. Псаммофильные чернотелки (Coleoptera: Tenebrionidae) побережий Черного (кавказская часть) и Азовского морей // Биологическое разнообразие Кавказа: Tp. XIV Междунар. конф. (Махачкала, 5-7 ноября 2012 г.). - Махачкала: Изд. Ин-та приклад. экологии Республики Дагестан, 2012. - С. 186-187.

765. Набоженко M.В. Жуки-чернотелки рода Probaticus Seidlitz, 1896 (Coleoptera: Tenebrionidae) Кавказа // Биологическое разнообразие Кавказа: Матер. XII Междунар. конф. (Махачкала, 4-7 ноября 2010 г.). Махачкала: Изд-во Дагестан. гос. ун-та, 2010. - С. 391-392.

766. Набоженко М.В. Жуки-чернотелки родов Ectromopsis Allard, 1876 и Xanthomus Mulsant, 1854 (Coleoptera: Tenebrionidae) - представители супралиторальных фаун древних и современных морских бассейнов // Фундаментальные проблемы энтомологии в XXI веке: Матер. Междунар. науч. конф. (Санкт-Петербург, 16-20 мая 2011 г.). - СПб.: Изд-во СПбГУ, 2011. С. 111.

767. Набоженко М.В. Почвообитающие личинки жуков-чернотелок (Coleoptera: Tenebrionidae): морфологическая специализация и таксономическое значение // Проблемы почвенной зоологии: Матер. XVI Всерос. совещ. по почвенной зоологии (Ростов-на-Дону, 4-7 октября 2011 г.). - М: Тов-во науч. изд. КМК, 2011. - С. 86-87.

768. Набоженко M.B. Новые виды рода Armenohelops Nabozhenko, 2002 (Coleoptera: Tenebrionidae: Helopini) из Турции // Кавказский энтомол. бюл. - 2011. - Т. 7, № 2. - С. 135-138.

769. Набоженко М.В. Жуки-чернотелки (Coleoptera: Tenebrionidae s. str.), предлагаемые для включения в Красную книгу Краснодарского 
края // Результаты мониторинга видов растений, животных и грибов, занесенных в Красную книгу Краснодарского края (2007-2011). Ижевск: Изд. дом «Университет», 2012. - С. 161-163.

770. Набоженко М.В. 279. Лена Юстины - Laena justinae (Reitter, 1887) // Красная книга Республики Адыгея. Редкие и находящиеся под угрозой исчезновения объекты животного и растительного мира: В 2-х ч. - Изд. 2-е. - Майкоп: Качество, 2012. - Ч. 2. Животные. - С. 127.

771. Набоженко М.В. Причины разрывов в ареалах жуковчернотелок трибы Helopini (Coleoptera: Tenebrionidae) // Материалы XV Международной научной конференции «Биологическое разнообразие Кавказа и Юга России» (г. Махачкала, 5-6 ноября 2013 г.) - Махачкала: Изд. Ин-та приклад. экологии Республики Дагестан, 2013. - С. 177-178.

772. Набоженко М.В., Абдурахманов Г.М. Итоги изучения фауны жуков-чернотелок (Coleoptera: Tenebrionidae s. str.) Кавказа и юга европейской части России // Биологическое разнообразие Кавказа: Tp. XIV Междунар. конф. (Махачкала, 5-7 ноября 2012). - Махачкала: Изд. Ин-та приклад. экологии Республики Дагестан, 2012. - С. 201-202.

773. Набоженко М.B., Кескин Б. Дизъюнктивный ареал Odocnemis protinus (Reitter, 1900) - первого представителя рода (Coleoptera: Tenebrionidae: Helopini) в Иране // Юг России: экология, развитие. 2013. - № 3. - С. 66-72.

774. Набоженко М.В., Никитский Н.Б. 278. Метаклиза синяя Metacliza azurea (Waltl, 1838) // Красная книга Республики Адыгея. Редкие и находящиеся под угрозой исчезновения объекты животного и растительного мира. В 2-х ч. - Изд. 2-е. - Майкоп: Качество, 2012. Ч. 2. Животные. - С. 126.

775. Набоженко М.В., Кескин Б., Кескин Н.А. Молекулярногенетические исследования жуков-чернотелок рода Odocnemis (Coleoptera: Tenebrionidae) // Молекулярно-генетические подходы в таксономии и экологии: Тез. докл. науч. конф. (25-29 марта 2013 г., Ростов-на-Дону). Ростов н/Д.: Изд-во ЮНЦ РАН, 2013. - С. 65.

776. Набоженко М.В., Шохин И.В., Марахонич А.В. Псаммофильные жесткокрылые сем. Tenebrionidae и Scarabaeidae (Coleoptera) побережий Азовского моря и Нижнего Дона // Tp. XIV съезда Русского энтомологического общ-ва (Санкт-Петербург, 26 августа-1 сентября 2012 г.). - СПб.: Изд. Зоол. ин-та РАН, 2012. - С. 300.

777. Набоженко М.В., Шохин И.В., Марахонич А.В. Супралиторальная колеоптерофауна (Insecta: Coleoptera) песчаных побережий Таганрогского залива // Экологическая безопасность приморских регионов (порты, берегозащита, рекреация, марикультура): Матер. 
Междунар. науч. конф., посвященной 150-летию Н.М. Книповича (Ростов-на-Дону, 5-8 июня 2012 г.). - Ростов н/Д.: Изд-во ЮНЦ РАН, 2012. - C. 163-166.

778. Основные закономерности распределения и генезис псаммофильных жесткокрылых понто-каспийского региона на примере Tenebrionidae и Scarabaeoidea (Insecta: Coleoptera) / M.В. Набоженко, И.В. Шохин, Г.М. Абдурахманов, А.Н. Кльчева, А.В. Марахонич, Д.И. Олейник // Юг России: экология, развитие. - 2012. - № 1. - С. 110-126.

779. Пономарев А.В., Лебедева Н.В. Пауки (Aranei) и некоторые их ценотические связи в байрачных лесах Нижнего Дона // Аридные экосистемы. - 2014. - Т. 20, № 2(59). - С. 80-91.

780. Трансформация таксоцена тенебрионид-лихенофагов в экотонах «лес-степь» / М.В. Набоженко, Н.В. Лебедева, С.В. Набоженко, В.Д. Лебедев // Энтомол. обозрение. - 2015. - Т. 94, № 4. - С. 868-883.

781. Фенология вылета хирономид (Diptera: Chironomidae) в Таганрогском заливе Азовского моря / Н.И. Бульшщева, М.В. Набоженко, А.И. Савикин, И.В. Шохин // Кавказский энтомол. бюл. - 2013. - Т. 9, вып. 2. - С. 329-332.

782. Хирономиды (Diptera: Chironomidae) донных сообществ Таганрогского залива Азовского моря / Н.И. Бульшшева, М.В. Набоженко, А.И. Савикин, И.В. Шохин // Экосистемные исследования среды и биоты Азовского бассейна. - Ростов н/Д.: Изд-во ЮНЦ РАН, 2012. - С. 171-177.

783. Introduction of invertebrates into the High Arctic via imported soils: the case of Barentsburg in the Svalbard / S.J. Coulson, A. Fjellberg, D.J. Gwiazdowicz, N.V. Lebedeva, E.N. Melekhina, T. Solhøy, Ch. Erséus, K. Maraldo, L. Miko, H. Schatz, R.M. Schmelz, G. Søli, E. Stur // Biological Invasions. - 2012. - P. 1-5. - Doi: 10.1007/s10530-012-0277-y

784. Keskin B., Nabozhenko M.V. Review of the genus Odocnemis Allard, 1876: O. korbi species-group (Coleoptera: Tenebrionidae: Helopini) // Annales zoologici. - 2011. - Vol. 61, № 2. - P. 339-354.

785. Keskin B., Nabozhenko M.V. Idahelops alpagutae (Coleoptera: Tenebrionidae: Helopini): a new genus and species from the Aegean region of Turkey // Zootaxa. - 2012. - Vol. 3207. - P. 63-67.

786. Kirejtshuk A.G., Nabozhenko M.V., Nel A. New genus and species of the tribe Opatrini (Coleoptera, Tenebrionidae, Tenebrioninae) from the lowermost eocene amber of Paris Basin // Proceedings of the Zoological Institute RAS. - 2010. - Vol. 314, № 2. - P. 191-196.

787. Kirejtshuk A.G., Nabozhenko M.V., Nel A. First mesozoic representative of the subfamily tenebrioninae (Coleoptera, Tenebrionidae) 
from the lower cretaceous of Yixian (China, Liaoning) // Entomological Review. - 2012. - Vol. 92, № 1. - P. 97-100. - Doi: 10.1134/S0013873812010101. URL: http://www.springerlink.com/content/m12m27x3074458m8/

788. Lebedeva N.V. Arboricular oribatid mites (Acari, Oribatida) in nests and birds from Ciscaucasus // XIV International Congress of Acarology (13-18 ${ }^{\text {th }}$, July, 2014, Kyoto, Japan): Abstr. book. Kyoto, 2014, - P. 137.

789. Lebedeva N.V., Taskaeva A.A. Collembola (Arthropoda: Hexapoda) from the Arctic Skua (Stercorarius parasiticus L.) habitat on the Nordaustlandet (Svalbard) // Russian Entomol. J. - 2012. - Vol. 21(4). - P. 351-355.

790. Lebedeva N.V., Poltavskaya M.P. Oribatid mites (Acari, Oribatida) of plain area of the southern european Russia // Zootaxa. - 2013. - Vol. 3709, № 2. - P. 101-133.

791. Microarthropod communities of industrially disturbed or imported soils in the High Arctic; the abandoned coal mining town of Pyramiden, Svalbard / S.J. Coulson, A. Fjellberg, E.N. Melekhina, A.A. Taskaeva, N.V. Lebedeva, O.A. Belkina, S. Seniczak, A. Seniczak, D.J. Gwiazdowicz // Biodiversity and Conservations. - 2015. - Vol. 24, № 7. P. 1671-1690.

792. Nabozhenko M.V. New combination and new synonymy in the subtribe Cylindrinotina (Coleoptera, Tenebrionidae, Helopini) based on the study of types from European museums // Deutsche Entomologische Zeitschrift. - 2011. - Vol. 58, № 2. - P. 275-277.

793. Nabozhenko M.V. Two new species of the genus Nalassus Mulsant, subgenus Helopondrus Reitter (Coleoptera: Tenebrionidae) from Turkey // Stuttgarter Beiträge zur Naturkunde A, Neue Serie. - 2011. Vol. 4. - P. 263-267.

794. Nabozhenko M.V. Two new species of the tribe Helopini (Coleoptera: Tenebrionidae) from Artvin Province, Turkey // Annales zoologici. - 2011. - Vol. 61, № 2. - P. 335-338.

795. Nabozhenko M.V. A review of the genus Nalassus Mulsant, 1854 (Coleoptera: Tenebrionidae: Helopini) of China with new concept of the distribution of the genus // Кавказский энтомол. бюл. - 2012. - Т. 8, № 1. - C. 33-36.

796. Nabozhenko M.V. New taxa of the genus Nalassus Mulsant, 1854 from Georgia // Кавказский энтомол. бюл. - 2013. - Т. 9, № 2. - С. 261-264.

797. Nabozhenko M.V. Taxonomic notes on the genera Hedyphanes Fischer von Waldheim, 1820 and Entomogonus Solier, 1848 (Coleoptera: Tenebrionidae) of Turkey // J. Insect Biodiversity. - 2013. - Vol. 1, № 8. P. 1-9. 
798. Nabozhenko M.V., Keskin B. Results of taxonomic and molecular study of the genus Odocnemis Allard, 1876 (Coleoptera: Tenebrionidae) of Turkey and Transcaucasia // Биологическое разнообразие Кавказа: Tp. XIV Междунар. конф. (Махачкала, 5-7 ноября 2012). - Махачкала: Изд. Ин-та приклад. экологии Республики Дагестан, 2012. - С. 263.

799. Nabozhenko M.V., Kirejtshuk A.G. Cryptohelops menaticus - a new genus and species of the tribe Helopini (Coleoptera: Tenebrionidae) from the Palaeocene of Menat (France) // C.R. Palevol. - 2014. Vol. 13. - P. 65-71. URL: http://www.sciencedirect.com/science/article/pii/S1631068313001486

800. Nabozhenko M.V., Lillig M. A new subgenus and species of the genus Hedyphanes Fischer von Waldheim, 1820 (Coleoptera: Tenebrionidae: Helopini) from Israel and Egypt // Zootaxa. - 2013. - Vol. 3641, № 2. - P. 188-192.

801. Nabozhenko M.V., Tichý $V$. Two new species of the genus Entomogonus Solier, 1848 (Coleoptera: Tenebrionidae) from Turkey // Кавказский энтомол. бюл. - 2011. - Т. 7, № 1. - С. 45-49.

802. Nabozhenko M.V., Bousquet Y., Bouchard P. Nomenclatural notes on the species recorded and described under the name Helops gracilis (Coleoptera: Tenebrionidae) // Annales zoologici. - 2012. - Vol. 62, № 4. - P. 725-731.

803. Nekhaeva A.A., Nekhaev I.O. On the spider fauna of Bolshoy Aynov Island (Barents Sea) (Arachnida: Arenei) // Arthropoda Selecta. 2011. - Vol. 20, № 4. - P. 319-322.

804. Ponomarev A.V., Lebedeva N.V. Spiders (Aranei) and some of their cenotic links in gully forests of the Lower Don River // Arid Ecosystems. - 2014. Vol. 4, № 2. - P. 107-118.

805. Purchart L., Nabozhenko M.V. Description of larva and pupa of the genus Deretus (Coleoptera: Tenebrionidae) with key to the larvae of the tribe Helopini // Acta Entomologica Musei Nationalis Pragae. - 2012. Vol. 52 (Suppl. 2). - P. 295-302.

806. The invertebrate fauna of the anthropogenic soils in the High Arctic settlement of Barentsburg; Svalbard / S.J. Coulson, A. Fjellberg, D.J. Gwiazdowicz, N.V. Lebedeva, E.N. Melekhina, T. Solhøy, C. Erséus, K. Maraldo, L. Miko, H. Schatz, R.M. Schmelz, G. Søli, E. Stur // Polar Res. 2013. - Vol. 32. - Article № 19273. - Doi: org/10.3402/polar.v32i0.19273

\section{птицы}

807. Баданин Ю.А. Состав и распределение авифауны Баренцева и Карского морей в зимне-весенний период 2013 года по данным 
судовых наблюдений // Эколого-эволюционные исследования морских организмов и экосистем: Матер. XIV Междунар. науч. конф. студентов и аспирантов «Проблемы Арктического региона» (г. Мурманск, май 2014 г.). Т. І. Форум молодых ученых, посвященный 110-летию со дня рождения Ю.И. Полянского (XXXII конференция молодых ученых ММБИ). - Мурманск: Изд. ММБИ КНЦ РАН, 2014. - С. 16-22.

808. Баданин Ю.А., Дерябин А.А. Авифауна Баренцева и Карского морей по трассе Северного морского пути в зимне-весенний период 2013-2014 гг. // Арктическое морское природопользование в XXI веке современный баланс научных традиций и инноваций (к 80-летию ММБИ КНЦ РАН): Тез. докл. Междунар. науч. конф. (г. Мурманск, 1-3 апреля 2015 г.). - Апатиты: Изд-во КНЦ РАН, 2015. - С. 14-15.

809. Бианки В.В., Краснов Ю.В. Материалы к познанию птиц района дельты Печоры (неворобьиные) // Рус. орнитол. журн. - 2015. T. 24, № 1103. - C. 414-423.

810. Биотические последствия изменения местообитаний в колониях и колониальных поселениях птиц в высокой Арктике / Н.В. Лебедева, С.Дж. Коулсон, Д.Дж. Гвяздович, А.А. Таскаева, Е.Н. Мелехина, T. Солхой // Теоретические аспекты колониальности у птиц. - Ростов н/Д.: Изд-во ЮНЦ РАН, 2012. - С. 88-91.

811. Влияние экологических факторов на размножение обыкновенной пустельги и кобчика в долине Маныча / Н.В. Лебедева, А.И. Ермолаев, Л.Ф. Скрылева, А.С. Родимиев, М.А. Микляева // Вестн. Южного науч. центра РАН. - 2011. - Т. 7, № 2. - С. 78-85.

812. Влияние факторов среды на воспроиводство кряквы / Н.Х. Ломадзе, Н.В. Лебедева, С.Г. Коломейцев, В.В. Куликов // Сохранение разнообразия животных и охотничье хозяйство России: Матер. 4-й Междунар. науч.-практ. конф. (г. Москва, 17-18 февраля 2011 г.). М.: Изд-во РГАУ-МСХА им. К.А. Тимирязева, 2011. - С. 415-418.

813. Гаврило М.В., Краснов Ю.В., Чупин И.И. Первая регистрация кулика-воробья Calidris minuta и краснозобика Calidris ferruginea на архипелаге Земля Франца-Иосифа // Рус. орнитол. журн. - 2014. Т. 23. - Экспресс-вып. № 962. - С. 271-273.

814. Горяева A.A. Гнездовая стратегия синатропной группировки серебристых чаек в городе Мурманске // Теоретические аспекты колониальности у птиц. - Ростов н/Д.: Изд-во ЮНЦ РАН, 2012. C. $150-153$.

815. Горяева А.А. Экология морских птиц, обитающих в антропогенных ландшафтах // Птицы северных и южных морей России: фауна, экология. - Апатиты: Изд-во КНЦ РАН, 2013. - С. 117-123. 
816. Горяева A.A. Об отдельных случаях обнаружения новых кормовых стаций представителями синантропной группировки серебристых чаек в окрестностях Мурманска // Арктическое морское природопользование в XXI веке - современный баланс научных традиций и инноваций (к 80-летию ММБИ КНЦ РАН): Тез. докл. Междунар. науч. конф. (г. Мурманск, 1-3 апреля 2015 г.). - Апатиты: Изд-во КНЦ РАН, 2015. - С. 40-42.

817. Горяев Ю.И., Ежов А.В., Горяева А.А. О гнездовании орланабелохвоста (Haliaeetus albicilla) на технических сооружениях в тундре Южного Ямала // Беркут. - 2014. - Вып. 1(23). - С. 30-31.

818. Динкевич М.А., Маркитан Л.В. Встреча облигатных птицнекрофагов в равнинной части республики Адыгея (окрестности г. Краснодара) // Стрепет. - 2010. - Т. 8, вып. 2. - С. 101-106.

819. Динкевич М.А., Маркитан Л.В. Материалы к фауне птиц Цимлянского водохранилища и его окрестностей // Цимлянское водохранилище: состояние водных и прибрежных экосистем, проблемы и пути решения. - Ростов н/Д.: Изд-во ЮНЦ РАН, 2011. - С. 94-102.

820. Ежов A.B. Устойчивость колоний моевок Rissa tridactula в Баренцевоморском регионе в современных условиях // Теоретические аспекты колониальности у птиц. - Ростов н/Д.: Изд-во ЮНЦ РАН, 2012. - C. 154-158.

821. Ежов А.В. Современное состояние гнездовых популяций моевок и кайр побережья Мурмана // Актуальные проблемы естествознания, физической культуры и безопасности жизнедеятельности: Матер. науч.-практ. конф. студентов факультета естествознания, физической культуры и безопасности жизнедеятельности МГГУ (7-14 апреля 2014 года). - Мурманск: Изд-во Мурм. гос. гуманит. ун-та, 2014. - C. 26-29.

822. Ежов A.B. Трофические условия и их влияние на состояние колоний моевок и кайр в южной части Баренцева моря // Север в XXI веке: среда обитания, общество, освоение: Матер. I Междунар. науч.практ. конф., 1-4 декабря 2014 г. - Мурманск: АНО АЦНИЭ, 2014. C. $144-150$.

823. Ежов A.B. Численность и репродуктивные показатели в птичьих колониях Мурмана как индикатор состояния кормовой базы в пред- и гнездовой период // Эколого-эволюционные исследования морских организмов и экосистем: Матер. XIV Междунар. науч. конф. студентов и аспирантов «Проблемы Арктического региона» (г. Мурманск, май 2014 г.). Т. І. Форум молодых ученых, посвященный 110 -летию со дня рождения Ю.И. Полянского (XXXII конференция молодых ученых ММБИ). - Мурманск: Изд. ММБИ КНЦ РАН, 2014. - С. 67-74. 
824. Ежов A.B. Итоги 15-летнего мониторинга крупнейших материковых колоний моевок и кайр побережья Мурмана // Вестн. Кольского науч. центра РАН. - 2015. - № 2(21). - С. 53-58.

825. Ежов A.B. Основные угрозы для колоний морских птиц побережья Мурмана // Арктическое морское природопользование в XXI веке - современный баланс научных традиций и инноваций (к 80-летию ММБИ КНЦ РАН): Тез. докл. Междунар. науч. конф. (г. Мурманск, 1-3 апреля 2015 г.). - Апатиты: Изд-во КНЦ РАН, 2015. - С. 61-63.

826. Ежов A.B. Основные угрозы и возможные пути охраны колоний морских птиц побережья Мурмана // Социальное развитие северных территорий России и зарубежных стран: опыт, проблемы, перспективы: Матер. Междунар. конф., 20-21 ноября 2014 г. Мурманск: Изд-во Мурм. гос. гуманит. ун-та, 2015 - С. 69-72.

827. Ермолаев А.И., Лебедева Н.В. Топические связи кобчика Falco vespertinus в колониальных поселениях на юге европейской части России // Теоретические аспекты колониальности у птиц. Ростов н/Д.: Изд-во ЮНЦ РАН, 2012. - С. 159-167.

828. Ермолаев А.И., Лебедева Н.В. О пищевом спектре кобчика // Птицы Кавказа: история изучения, жизнь в урбанизированной среде: Матер. науч.-практ. конф. (г. Кисловодск, станция юных натуралистов, 29 апреля-1 мая 2013 г.). - Ставрополь: Альфа-Принт, 2013. - С. 72-75.

829. Ермолаев А.И., Лебедева Н.В. Эколого-этологические особенности питания обыкновенной пустельги и кобчика в период размножения на юге европейской России // Хищные птицы Северного Кавказа и сопредельных территорий: распространение, экология, динамика популяций, охрана: Матер. Междунар. конф. (8-10 апреля 2014 г., г. Сочи). - Ростов н/Д.: Изд-во Южного фед. ун-та, 2014. - С. 216-221.

830. Ермолаев А.И., Лебедева Н.В., Скрылева Л.Ф. Экология размножения обыкновенной пустельги (Falco tinnunculus L.) в долине Маныча // Изучение и освоение морских и наземных экосистем в условиях арктического и аридного климата: Матер. Междунар. науч. конф. (6-11 июня 2011 г., Ростов-на-Дону). - Ростов н/Д.: Изд-во ЮНЦ PAH, 2011. - C. 272-274.

831. Зимовки морских уток в Баренцевом и Белом морях: размещение и численность / Т. Аарвак, Ю.В. Краснов, М.В. Гаврило, A.A. Шавыкин // Глобальные климатические процессы и их влияние на экосистемы арктических и субарктических регионов: Тез. докл. Междунар. науч. конф. (г. Мурманск, 9-11 ноября 2011 г.). - Апатиты: Изд-во КНЦ РАН, 2011. - С. 7-8. 
832. Зубакин В.А., Лебедева Н.В., Краснов Ю.В. Введение // Теоретические аспекты колониальности у птиц. - Ростов н/Д.: Изд-во ЮНЦ РАН, 2012. - С. 9-12.

833. Иваненко Н.Ю. Особенности гнездования серого гуся (Anser anser) на Айновых островах (Варангер-фьорд, Баренцево море) // Гусеобразные Северной Евразии: география, динамика и управление популяциями: Тез. докл. Междунар. конф. (24-29 марта 2011 г., г. Элиста, Республика Калмыкия, Россия). - Элиста: Б.и., 2011. - С. 36.

834. Иваненко Н.Ю. Результаты орнитологических наблюдений на Айновых островах в 2010 году // Материалы XXIX конференции молодых ученых Мурманского морского биологического института, посвященной 140-летию со дня рождения Г.А. Клюге, «Морские исследования экосистем европейской Арктики» (г. Мурманск, май 2011 г.). - Мурманск: Изд. ММБИ КНЦ РАН, 2011. - С. 85-89.

835. Иваненко Н.Ю. Численность и распределение птиц в Грёнфьорде (Западный Шпицберген) в позднелетний период 2011 года // Комплексные исследования природы Шпицбергена: Матер. Междунар. науч. конф. (Мурманск, 1-3 ноября 2012 г.). Вып. 11. - М.: ГЕОС, 2012. - C. 91-101.

836. Иваненко Н.Ю. Особенности гнездования серого гуся Anser anser на Айновых островах (Варангер-фьорд, Баренцево море) // Рус. орнитол. журн. - 2013. - Т. 22. - Экспресс-вып. № 855. - С. 649-650.

837. Иваненко Н.Ю. Квадрат 33XVG3. Мурманская область // Фауна и население птиц европейской России: ежегод. программы «Птицы Москвы и Подмосковья». - М.: Фитон XXI, 2013. - Вып. 1. - С. 17-19.

838. Иваненко Н.Ю. Квадрат 36WVC2. Мурманская область // Фауна и население птиц европейской России: ежегод. программы «Птицы Москвы и Подмосковья». - М.: Фитон XXI, 2013. - Вып. 1. - С. 165-167.

839. Иваненко Н.Ю. Орнитофауна Западного Мурмана на примере губы Печенга и Айновых островов // Птицы северных и южных морей России: фауна, экология. - Апатиты: Изд-во КНЦ РАН, 2013. - С. 64-102.

840. Иваненко Н.Ю. Особенности гнездования обыкновенной гаги в Грён-фьорде // Современные проблемы экологии и природопользования: Матер. регион. науч.-практ. конф., посвященной 15-летию со дня основания кафедры биоэкологии, Мурманск, 27-28 февраля 2014 г. Мурманск: Изд-во Мурм. гос. техн. ун-та, 2014. - С. 92-96.

841. Иваненко Н.Ю. Особенности размещения гнезд и фенология размножения обыкновенной гаги в окрестностях поселков Баренцбург и Лонгиербюен (Шпицберген) // Комплексные исследования природы 
Шпицбергена и прилегающего шельфа: Матер. Междунар. науч. конф. (Мурманск, 6-8 ноября 2014 г.). Вып. 12. - М.: ГЕОС, 2014. - С. 116-121.

842. Изменения ареалов чайковых птиц в регионе Кольского полуострова / Ю.В. Краснов, Ю.И. Горяев, А.В. Еэсов, Н.Ю. Иваненко // Глобальные климатические процессы и их влияние на экосистемы арктических и субарктических регионов: Тез. докл. Междунар. науч. конф. (г. Мурманск, 9-11 ноября 2011 г.). - Апатиты: Изд-во КНЦ PAH, 2011. - C. 99-101.

843. Использование GPS-навигатора для картирования колоний птиц: методическая проверка / С.П. Харитонов, Н.Ю. Иваненко, И.П. Чухарева, Ю.А. Анисимов // Поволжский экол. журн. - 2011. - № 1. - С. 59-69.

844. Карнатов А.Н., Багатько О.Ю. Численность и распределение основных видов морских птиц на акватории Баренцева моря в сентябре 1997 г. // Материалы XXX юбилейной конференции молодых ученых Мурманского морского биологического института, посвященной 150летию со дня рождения Н.М. Книповича, «Проблемы океанографии, биологии и освоения биоресурсов морей российской Арктики» (г. Мурманск, май 2012). - Мурманск: Изд. ММБИ КНЦ РАН, 2012. C. $80-86$.

845. Краснов Ю.В. Итоги орнитологических исследований в юговосточной части Печорского моря // Изучение и освоение морских и наземных экосистем в условиях арктического и аридного климата: Матер. Междунар. науч. конф. (6-11 июня 2011 г., Ростов-на-Дону). Ростов н/Д.: Изд-во ЮНЦ РАН, 2011. - С. 277-279.

846. Краснов Ю.В. Летние орнитологические наблюдения 2007 г. на западном побережье о. Вайгач // Наземные и морские экосистемы. М.; СПб.: Paulsen, 2011. - С. 336-343.

847. Краснов Ю.В. Северная олуша Morus bassanus (Linnaeus, 1758) // Птицы России и сопредельных регионов. Пеликанообразные, аистообразные, фламингообразные. - М.: Тов-во науч. изд. КМК, 2011. C. 39-46.

848. Краснов Ю.В. Колониальное гнездование обыкновенной гаги Somateria mollissima: адаптивные механизмы и условия формирования // Теоретические аспекты колониальности у птиц. - Ростов н/Д.: Изд-во ЮНЦ РАН, 2012. - С. 173-180.

849. Краснов Ю.В. Морские птицы: современное состояние популяций, распределение и трофические связи // Биологические ресурсы Белого моря: изучение и использование. - СПб.: Изд. Зоол. ин-та РАН, 2012. - С. 244-260 (Исследования фауны морей. Т. 69(77). 
850. Краснов Ю.В. Социальная структура поселения моевок Rissa tridactyla и факторы, ее определяющие // Теоретические аспекты колониальности у птиц. - Ростов н/Д.: Изд-во ЮНЦ РАН, 2012. C. 181-191.

851. Краснов Ю.В. Результаты орнитологических исследований в Белом море летом 2006 г. // Экология морских птиц Белого моря. Апатиты: Изд-во КНЦ РАН, 2012. - С. 12-31.

852. Краснов Ю.В. Об исследовании популяции обыкновенной гаги Somateria mollissima в Белом море // Экология морских птиц Белого моря. - Апатиты: Изд-во КНЦ РАН, 2012. - С. 31-44.

853. Краснов Ю.В. Колониальность у птиц: критический анализ взглядов В.М. Модестова по итогам наблюдений в Баренцевоморском регионе // Зоол. журн. - 2012. - Т. 91, № 7. - С. 795-799.

854. Краснов Ю.В. История отечественных исследований морских птиц // Птицы северных и южных морей России: фауна, экология. Апатиты: Изд-во КНЦ РАН, 2013. - С. 7-16.

855. Краснов Ю.В. Основные направления исследований морских птиц Мурманским морским биологическим институтом КНЦ РАН в северных морях европейской части России // Тр. Кольского науч. центра РАН. - 2013. - Т. 1(14). - Сер. Океанология. - Вып. 1. - С. 111-127.

856. Краснов Ю.В. Орнитофауна западного побережья о. Вайгач и прилегающих островов // Морские экосистемы и сообщества в условиях современных климатических изменений. - СПб.: Реноме, 2014. C. 295-312.

857. Краснов Ю.В. Орнитологические наблюдения на острове Гукера (Земля Франца-Иосифа) и его окрестностях в августе 1993 г. // Тр. Кольского науч. центра РАН. - 2014. - № 4(23). - Сер. Океанология. Вып. 2. - С. 252-263.

858. Краснов Ю.В. Характеристика орнитофауны и исследование ее роли в экосистеме Баренцева моря на современном этапе // Комплексные исследования больших морских экосистем России. Апатиты: Изд-во КНЦ РАН, 2011. - С. 258-277.

859. Краснов Ю.В., Горяев Ю.И. Итоги летних наблюдений за птицами на западном берегу Горла Белого моря // Экология морских птиц Белого моря. - Апатиты: Изд-во КНЦ РАН, 2012. - С. 105-128.

860. Краснов Ю.В., Горяев Ю.И. Основные тенденции развития авифауны Кольского залива и факторы ее определяющие // Птицы северных и южных морей России: фауна, экология. - Апатиты: Изд-во КНЦ РАН, 2013. - С. 38-64. 
861. Краснов Ю.В., Ежов А.В. Современное состояние популяции моевок (Rissa tridactyla) и кайр (Urua aalage и U. lomvia) на Мурмане // Птицы северных и южных морей России: фауна, экология. - Апатиты: Изд-во КНЦ РАН, 2013. - С. 102-117.

862. Краснов Ю.В., Ежсов А.В. О реакции морских птиц Баренцева моря на современные климатические изменения // Состояние арктических морей и территорий в условиях изменения климата: Тез. Всерос. конф. с междунар. участием. - Архангельск: Изд. дом Сев. (Арктич.) фед. ун-та им. М.В. Ломоносова, 2014. - С. 103-104.

863. Краснов Ю.В., Ежов А.В. Результаты изучения кочевок моевок Rissa tridactyla Восточного Мурмана во внегнездовой период на современном этапе // Арктическое морское природопользование в XXI веке - современный баланс научных традиций и инноваций (к 80-летию ММБИ КНЦ РАН): Тез. докл. Междунар. науч. конф. (г. Мурманск, 1-3 апреля 2015 г.). - Апатиты: Изд-во КНЦ РАН, 2015. - С. 113-115.

864. Краснов Ю.В., Гаврило М.В., Аарвак Т. Зимовки морских уток в Белом море и на Мурмане: характер размещения и адекватные методы учета // Гусеобразные Северной Евразии: география, динамика и управление популяциями: Тез. докл. Междунар. конф. (24-29 марта 2011 г., г. Элиста, Республика Калмыкия, Россия). - Элиста: Б.и., 2011. - С. 46.

865. Краснов Ю.В., Гаврило М.В., Шавыкин А.А. Состояние, численность и организация мониторинга популяций обыкновенной гаги (Somateria mollissima) в Баренцевом и Белом морях // Зоол. журн. 2015. - T. 94, № 1. - C. 62-67.

866. Краснов Ю.В., Горяев Ю.И., Ежов А.В. Характеристика орнитофауны на современном этапе // Птицы северных и южных морей России: фауна, экология. - Апатиты: Изд-во КНЦ РАН, 2013. - С. 16-38.

867. Краснов Ю.В., Горяев Ю.И., Ежов А.В. Морские и водоплавающие птицы Белого моря: сезонная динамика и характер распределения // Птицы северных и южных морей России: фауна, экология. - Апатиты: Изд-во КНЦ РАН, 2013. - С. 124-158.

868. Краснов Ю.В., Спиридонов В.А., Добрынин Д.В. Морские птицы на Восточном Мурмане и в северной части Белого моря в летний период: особенности распределения и различия кормовой базы // Экология морских птиц Белого моря. - Апатиты: Изд-во КНЦ PAH, 2012. - C. 44-66.

869. Краснов Ю.В. Шкляревич Г.А., Горяев Ю.И. Трофические связи обыкновенной гаги Somateria mollissima в пределах Белого моря // Экология морских птиц Белого моря. - Апатиты: Изд-во КНЦ РАН, 2012. - C. 67-105. 
870. Краснов Ю.В., Шкляревич Г.А., Сухотин А.А. Особенности питания обыкновенной гаги Somateria mollissima на западном побережье о. Вайгач // Докл. РАН. - 2014. - Т. 459, № 1. - С. 125-127.

871. Куклин В.В. Введение // Птицы северных и южных морей России: фауна, экология. - Апатиты: Изд-во КНЦ РАН, 2013. - С. 5-6.

872. Куклин В.В. Заключение // Птицы северных и южных морей России: фауна, экология. - Апатиты: Изд-во КНЦ РАН, 2013. - С. 262-265.

873. Куклин В.В., Куклина М.М. Гельминтофауна птиц Баренцева и Карского морей и взаимоотношения в системе гельминты-морские птицы // Птицы северных и южных морей России: фауна, экология. Апатиты: Изд-во КНЦ РАН, 2013. - С. 159-177.

874. Куклин В.В., Куклина М.М. Эколого-паразитологические исследования рыбоядных птиц Восточного Приазовья // Птицы северных и южных морей России: фауна, экология. - Апатиты: Изд-во КНЦ PAH, 2013. - C. 254-261.

875. Лебедева Н.В. Гусеобразные - вектор, способствующий расселению почвенных животных в Арктике // Гусеобразные Северной Евразии: география, динамика и управление популяциями: Тез. докл. Междунар. конф. (24-29 марта 2011 г., г. Элиста, Республика Калмыкия, Россия). - Элиста: Б.и., 2011. - С. 49.

876. Лебедева Н.В. Колониальные птицы в Предкавказье: основные направления исследований // Теоретические аспекты колониальности у птиц. - Ростов н/Д.: Изд-во ЮНЦ РАН, 2012. - С. 79-87.

877. Лебедева H.В. Панцирные клещи (Acari, Oribatida) в оперении и гнездах птиц побережья Азовского и Черного морей // Птицы северных и южных морей России: фауна, экология. - Апатиты: Изд-во КНЦ РАН, 2013. - С. 239-254.

878. Лебедева Н.В. Пуночка - снежная овсянка // Рус. вестн. Шпицбергена. - 2013. - № 6. - С. 26-27.

879. Лебедева H. Красногрудый чужеземец // Рус. вестн. Шпицбергена. - 2014. - № 11. - С. 19.

880. Лебедева Н.В. Об обыкновенном чистике // Рус. вестн. Шпицбергена. - 2014. - № 9. С. 31.

881. Лебедева Н.В. Птицы-дуплогнездники как модельные объекты биоиндикации // Птицы-дуплогнездники как модельные объекты в решении проблем популяционной экологии и эволюции: Матер. Междунар. конф. (г. Звенигород, 22-27 сентября 2014 г.). - М.: Тов-во науч. изд. КМК, 2014. - С. 167-170. 
882. Лебедева Н.B. Гуси на миграции и зимовке в бассейне Азовского моря // Арктическое морское природопользование в XXI веке - современный баланс научных традиций и инноваций (к 80-летию ММБИ КНЦ РАН): Тез. докл. Междунар. науч. конф. (г. Мурманск, 1-3 апреля 2015 г.). - Апатиты: Изд-во КНЦ РАН, 2015. - С. 133.

883. Лебедева Н.В. Состояние популяций водоплавающих птиц и опыт в поддержании их численности и разнообразия на юге европейской России // XIV Международная орнитологическая конференция Северной Евразии: Тез. докл. - Алматы: Мензбировское орнитол. общ-во, 2015. - С. 291-292.

884. Лебедева Н.В., Ермолаев А.И. Влияние погодноклиматических факторов на особенности размножения кобчика (Falco verpertinus) и обыкновенной пустельги (F. tinnunculus) в долине Маныча // Экология птиц: виды, сообщества, взаимосвязи: Тр. науч. конф., посвящ. 150-летию со дня рождения Н.Н. Сомова (1863-1923), 1-4 дек. 2011 г., г. Харьков, Украина: В 2-х кн. - Харьков: Изд-во Харьковского гос. ун-та, 2011. - Кн. 2. - С. 176-181 (Сомовская библиотека. Вып. 1. Экология птиц: виды, сообщества, взаимосвязи).

885. Лебедева Н.В., Ермолаев А.И. Особенности колониального гнездования кобчика Falco vespertinus L. в окрестностях озера МанычГудило // Аридные экосистемы. - 2012. - Т. 18, № 3(52). - С. 60-71.

886. Лебедева Н.В., Ермолаев А.И. Особенности гнездостроения грача (Corvus frugilegus L.) в колониальных поселениях в долине Маныча // Вестн. Южного науч. центра РАН. - 2014. - Т. 10, № 3. - С. 83-92.

887. Лебедева Н.В., Иваненко Н.Ю. О птичьих правах // Рос. вестн. Шпицбергена. - 2014. - № 10. - С. 18.

888. Лебедева Н.В., Ломадзе Н.Х. Редкие и малочисленные виды птиц Веселовского водохранилища // Современное состояние и технологии мониторинга аридных и семиаридных экосистем юга России. - Ростов н/Д.: Изд-во ЮНЦ РАН, 2010. - С. 118-128.

889. Лебедева Н.В., Ломадзе Н.Х. Кулики Веселовского водохранилища // Кулики Северной Евразии: экология, миграции и охрана: Матер. VIII Междунар. науч. конф. (10-12 ноября 2009 г., Ростов-на-Дону). - Ростов н/Д.: Изд-во ЮНЦ РАН, 2011. - С. 140-152.

890. Лебедева Н.В., Ломадзе Н.Х. Зимовка гусеобразных на Веселовском водохранилище (Западный Маныч) в 2010-2013 годах // Вестн. Южного науч. центра РАН.- 2013. - Т. 9, № 2. - С. 68-79.

891. Лебедева Н.В., Ломадзе Н.Х. Зимовка огаря на Веселовском водохранилище // Птицы Кавказа: история изучения, жизнь в урбани- 
зированной среде: Матер. науч.-практ. конф. (г. Кисловодск, станция юных натуралистов, 29 апреля-1 мая 2013 г.). - Ставрополь: АльфаПринт, 2013. - С.146-149.

892. Лебедева Н.В., Ломадзе Н.X. Турухтан на Веселовском водохранилище // Кулики в изменяющейся среде Северной Евразии: Матер. IX Междунар. науч. конф. (4-6 февраля 2012 г., Кисловодск). M.: Тезаурус, 2014. - C. 201-203.

893. Лебедева Н.В., Ломадзе Н.Х. Гнездование обыкновенной пустельги в необычном местообитании // Хищные птицы Северного Кавказа и сопредельных территорий: распространение, экология, динамика популяций, охрана: Матер. Междунар. конф. (8-10 апреля 2014, г. Сочи). - Ростов н/Д.: Изд-во Южного фед. ун-та, 2014. - С. 244-246.

894. Лебедева Н.В., Ломадзе Н.Х. Редкие виды птиц Веселовского водохранилища: динамика фауны в 2008-2014 гг. // Вестн. Южного науч. центра РАН. - 2015. - Т. 11, № 2. - С. 66-77.

895. Лебедева Н.В., Савицкий Р.М. Колониальные птицы Азовского моря // Комплексные исследования больших морских экосистем России. - Апатиты: Изд-во КНЦ РАН, 2011. - С. 410-428.

896. Лебедева Н.В., Ермолаев А.И., Ломадзе Н.Х. Смена биотопических предпочтений у обыкновенной пустельги: динамика процесса, возможные причины и выгоды // Проблемы эволюции птиц: систематика, морфология, экология и поведение: Матер. Междунар. конф. памяти Е.Н. Курочкина. - М.: Тов-во науч. изд. КМК, 2013. - С. 129-132.

897. Лебедева Н.В., Ермолаев А.И., Скрылева Л.Ф. Влияние погодных флуктуаций на величину кладки и оологическую изменчивость кобчика (Falco vespertinus L.) в долине Маныча // Теоретичні та практичні аспекті оологіi в сучасній зоології: Матер. Міжнар. наук.-практ. конф. - Київ: Фітосоціоцентр, 2011. - С. 269-273.

898. Лебедева Н.В., Ломадзе Н.Х., Коломейцев С.Г. Новые подходы к охране гусеобразных во временных зонах покоя на Веселовском водохранилище // Тр. Ростовского гос. охот. хоз-ва. Вып. 3. - 2013. C. $137-172$.

899. Лебедева Н.В., Ломадзе Н.Х., Коломейцев С.Г. Опыт поддержания численности и сохранения популяций гусеобразных на юге европейской России // Гусеобразные Северной Евразии: изучение, сохранение и рациональное использование: Тез. докл. Междунар. конф. (30 ноября-6 декабря 2015 г., г. Салехард, Россия). - Салехард: Б.и., 2015. - С. 49-50. 
900. Лебедева Н.В. , Ломадзе Н.Х., Коломейцев С.Г. Опыт восстановления и поддержания численности популяций гусеобразных на Веселовском водохранилище // Сохранение разнообразия животных и охотничье хозяйство России. - Реутов: ЭРА, 2015. - С. 388-391.

901. Лебедева Н.В., Пономарев А.В., Савицкий Р.М. Состояние аборигенной фауны в сохранившихся натуральных степных экосистемах юга европейской России // Сохранение степных и полупустынных экосистем Евразии: Тез. докл. Междунар. науч.-практ. конф., Алматы (Казахстан), 13-14 марта 2013 г. - Алматы: Изд. АСБК, 2013. - С. 96.

902. Ломадзе Н.Х., Лебедева Н.В. Биология московки (Parus ater L.) на северо-западном Кавказе // Социально-гуманитарные и экологические проблемы развития современной Адыгеи. - Ростов н/Д.: Изд-во ЮНЦ РАН, 2012. - С. 481-494.

903. Маркитан Л.В. Динамика прибрежно-водной растительности и биотопических предпочтений уток на лиманах Восточного Приазовья // Изучение и освоение морских и наземных экосистем в условиях арктического и аридного климата: Матер. Междунар. науч. конф. (6-11 июня 2011 г., Ростов-на-Дону). - Ростов н/Д.: Изд-во ЮНЦ РАН, 2011. - C. 292-295.

904. Маркитан Л.В. Сравнительная экология раннего онтогенеза камышевок (Acrocephalus, Sylviidae, Aves) в Восточном Приазовье // Экология птиц: виды, сообщества, взаимосвязи: Тр. науч. конф., посвященной 150-летию со дня рождения Н.Н. Сомова (1863-1923), 1-4 дек. 2011 г., г. Харьков, Украина: В 2-х кн. - Харьков: Изд-во Харьковского гос. ун-та, 2011. - Кн. 2. - С. 378-395 (Сомовская библиотека. Вып. 1. Экология птиц: Виды, сообщества, взаимосвязи).

905. Маркитан Л.В., Динкевич М.А. Современное состояние авифауны рыбообразных прудов дельты Дона // Экосистемные исследования среды и биоты Азовского бассейна. - Ростов н/Д.: Изд-во ЮНЦ РАН, 2012. - С. 214-244.

906. Матишов Г.Г., Савиикий Р.М. Элиминация водоплавающих видов птиц в Азовском море // Вестн. Южного науч. центра РАН, 2012. Т. 8. № 3. С. $50-54$.

907. Натурализация искусственно выращенной кряквы на водоемах Западного Маныча / Н.В. Лебедева, Н.Х. Ломадзе, С.Г. Коломейщев, В.В. Куликов, В.Н. Говорунов // Современные проблемы природопользования, охотоведения и звероводства: Матер. Междунар. науч.-практ. конф., посвящ. 90-летию ВНИИОЗ им. Б.М. Житкова (22-25 мая 2012 г.). Киров: Изд. ВНИИОЗ им. проф Б.М. Житкова, 2012. - С. 539-540. 
908. Особенности миграции реинтродуцированного на юге европейской России серого гуся (Anser anser) / H.B. Лебедева, Н.Х. Ломадзе, В.Н. Говорунов, А.М. Узденов // Энергетика и годовые циклы птиц: Матер. Междунар. конф. памяти В.Р. Дольника. - М.: Тов-во науч. изд. КМК, 2015. - С. 180-182.

909. Особенности экологических связей обыкновенной пустельги и кобчика в долине оз. Маныч-Гудило / А.И. Ермолаев, Н.В. Лебедева, А.С. Родимиев, Л.Ф. Скрылева, Р.М. Савиикий, М.А. Микляева // XIV Международная орнитологическая конференция Северной Евразии, г. Алматы, 18-24 августа 2015 г.: Тез. докл. - Алматы: Мензбировское орнитол. общ-во, 2015. - С. 185-186.

910. Программа изучения колониальности у птиц / B.A. Зубакин, Ю.К. Рощевский, Е.Э. Стоикая, Е.В. Сыроечковский, С.П. Харитонов, И.И. Черничко, Н.В. Лебедева // Теоретические аспекты колониальности у птиц. - Ростов н/Д.: Изд-во ЮНЦ РАН, 2012. - С. 246-264.

911. Результаты наблюдений миграций и сезонных размещений морских уток с борта морских судов на трассе Севморпути / Ю.В. Краснов, А.В. Ежов, Ю.И. Горяев, Ю.А. Баданин // Гусеобразные Северной Евразии: изучение, сохранение и рациональное использование: Тез. докл. Междунар. конф. (30 ноября-6 декабря 2015 г., Салехард, Россия). - Салехард: Б.и., 2015. - С. 100-101.

912. Савиикий Р.М. Альбинизм птиц отряда Passeriformes на юге России // Птицы Кавказа: современное состояние и проблемы охраны: Матер. науч.-практ. конф. - Ставрополь: Изд-во СевКавГТУ, 2011. C. $148-149$.

913. Савиикий Р.М. Гусеобразные - уязвимое звено при разливах нефтепродуктов на акваториях // Гусеобразные Северной Евразии: география, динамика и управление популяциями: Тез. докл. Междунар. конф. (24-29 марта 2011 г., г. Элиста, Республика Калмыкия, Россия). Элиста: Б.и, 2011. - С. 77-78.

914. Савицикий P.M. Миграции гусеобразных Азово-Черноморского региона // Изучение и освоение морских и наземных экосистем в условиях арктического и аридного климата: Матер. Междунар. науч. конф. (6-11 июня 2011 г., Ростов-на-Дону). - Ростов н/Д.: Изд-во ЮНЦ PAH, 2011. - C. 203-204.

915. Савиикий Р.М. Внутрипопуляционная изменчивость морфологических признаков воробьиных птиц // Социально-гуманитарные и экологические проблемы развития современной Адыгеи. - Ростов н/Д.: Изд-во ЮНЦ РАН, 2012. - С. 510-519.

916. Савиикий P.M. Авифауна Азовского моря и Восточного Приазовья в современный период // Птицы северных и южных морей России: фауна, экология. - Апатиты: Изд-во КНЦ РАН, 2013. - С. 215-231. 
917. Савиикий Р.М. Видовой состав и распределение морских птиц на акватории Черного моря // Птицы северных и южных морей России: фауна, экология. - Апатиты: Изд-во КНЦ РАН, 2013. - С. 210-215.

918. Савицкий Р.M. Влияние нефтяного загрязнения на водоплавающих и околоводных птиц Керченского пролива // Птицы северных и южных морей России: фауна, экология. - Апатиты: Изд-во КНЦ РАН, 2013. - С. 231-239.

919. Савицкий Р.М. Разнообразие морских видов птиц в АзовоЧерноморском регионе // Материалы XV Международной научной конференции «Биологическое разнообразие Кавказа и Юга России» (г. Махачкала, 5-6 ноября 2013 г.) - Махачкала: Изд. Ин-та приклад. экологии Республики Дагестан, 2013. - С. 201-203.

920. Савиикий P.M. Характер пребывания левантского буревестника Puffinus yelkouan на юге России // Рус. орнитол. журн. - 2013. - Т. 22, № 910. - C. 2244-2248.

921. Савицкий P.M. Пискулька Anser erythropus (Linnaeus, 1758) // Красная книга Ростовской области. - Ростов н/Д.: Изд. Минприроды Ростов. обл., 2014. - Т. 1. Животные. - С. 178.

922. Савиикий P.M. Белоглазый нырок (чернеть) Aythya nyroca (Guldenstadt, 1770) // Красная книга Ростовской области. - Ростов н/Д.: Изд. Минприроды Ростов. обл., 2014. - Т. 1. Животные. - С. 181.

923. Савицкий Р.М. Заметки о гнездовой экологии ходулочника и шилоклювки в долине Маныча // Кулики в изменяющейся среде Северной Евразии: Матер. Х Междунар. науч. конф. (4-6 февраля 2012 г., Кисловодск). - М.: Тезаурус, 2014. - С. 218- 219.

924. Савиикий P.M. Краснозобая казарка Rufibrenta ruficollis (Pallas, 1769) // Красная книга Ростовской области. - Ростов н/Д.: Изд. Минприроды Ростов. обл., 2014. - Т. 1. Животные. - С. 177.

925. Савиикий P.M. Малый лебедь Cygnus bewickii Yarrell, 1830 // Красная книга Ростовской области. - Ростов н/Д.: Изд. Минприроды Ростов. обл., 2014. - Т. 1. Животные. - С. 179.

926. Савиикий P.M. Серая утка Anas strepera Linnaeus, 1758 // Красная книга Ростовской области. - Ростов н/Д.: Изд. Минприроды Ростов. обл., 2014. - Т. 1. Животные. - С. 180.

927. Савиикий P.M. Савка Oxyura leucocephala (Scopoli, 1769) // Красная книга Ростовской области. - Ростов н/Д.: Изд. Минприроды Ростов. обл., 2014. - Т. 1. Животные. - С. 182.

928. Савиикий Р.M. Ходулочник Himantopus himantopus (Linnaeus, 1758) // Красная книга Ростовской области. - Ростов н/Д.: Изд. Минприроды Ростов. обл., 2014. - Т. 1. Животные. - С. 207. 
929. Савицкий Р.М. Зимовка и миграция обыкновенного гоголя на Азовском море // Арктическое морское природопользование в XXI веке - современный баланс научных традиций и инноваций (к 80-летию ММБИ КНЦ РАН): Тез. докл. Междунар. науч. конф. (г. Мурманск, 1-3 апреля 2015 г.). - Апатиты: Изд-во КНЦ РАН, 2015. - С. 210.

930. Савицкий P.M. Весенняя миграция воробьиных птиц в долине Маныча // Степные птицы Северного Кавказа и сопредельных регионов. Изучение, использование, охрана: Матер. Междунар. конф. (17-19 апреля 2015 г., с. Дивное). - Ростов н/Д.: Академцентр, 2015. - С. 220-222.

931. Савицкий P.M. Овсянка-ремез Emberiza rustica на юге европейской России // Междунар. журн. прикладных и фундаментальных исследований. 2015. - № 11-2. - C. 277-279. - URL: http://www.rae.ru/upfs/?section= content\&op=articles\&month $=11$ \&year $=2015 \&$ part $=2$

932. Савииякий Р.М. Особенности миграций воробьиных птиц центральной части Кумо-Манычской впадины // Успехи совр. естествознания. - 2015. - № 11-2. - С. 214-217.

933. Савиикий P.M. Зимовка и миграция гусеобразных на Азовском море // Гусеобразные Северной Евразии: изучение, сохранение и рациональное использование: Тез. докл. Междунар. конф. (30 ноября6 декабря 2015 г., г. Салехард, Россия). - Салехард: Б.и., 2015. - С. 78-79.

934. Савиикий P.М., Лебедева Н.В. Влияние пастбищной нагрузки на птиц // Изучение и освоение морских и наземных экосистем в условиях арктического и аридного климата: Матер. Междунар. науч. конф. (6-11 июня 2011 г., Ростов-на-Дону). - Ростов н/Д.: Изд-во ЮНЦ PAH, 2011. - C. 324-325.

935. Савицкий P.М., Лебедева Н.В. Гнездование гусеобразных в пессимальных условиях // Гусеобразные Северной Евразии: география, динамика и управление популяциями: Тез. докл. Междунар. конф. (2429 марта 2011 г., г. Элиста, Республика Калмыкия, Россия). - Элиста: Б.и., 2011. - С. 78.

936. Савицкий Р.М., Лебедева Н.В. Новые данные о куликах долины Маныча // Кулики Северной Евразии: экология, миграции и охрана: Матер. VIII Междунар. науч. конф. (10-12 ноября 2009 г., Ростов-на-Дону). - Ростов н/Д.: Изд-во ЮНЦ РАН, 2011. - С. 189-199.

937. Савиикий Р.М., Лебедева Н.В. Роль прибрежных территорий в поддержании разнообразия орнитофауны (на примере Беглицкой косы, Азовское море) // Экологическая безопасность приморских регионов (порты, берегозащита, рекреация, марикультура): Матер. Междунар. науч. конф., посвященной 150-летию Н.М. Книповича (Ростов-на-Дону, 5-8 июня 2012 г.). - Ростов н/Д.: Изд-во ЮНЦ РАН, 2012. - С. 208-213. 
938. Савицкий Р.М., Лебедева Н.В. Птицы фрагментарных степных сообществ вблизи мегаполиса // Птицы Кавказа: история изучения, жизнь в урбанизированной среде: Матер. науч.-практ. конф. (г. Кисловодск, станция юных натуралистов, 29 апреля-1 мая 2013 г.). Ставрополь: Альфа-Принт, 2013. - С. 166.

939. Савиикий Р.М., Лебедева Н.В. Квадрат 37TEN4. Ростовская область // Фауна и население птиц европейской России: ежегод. программы «Птицы Москвы и Подмосковья». - М.: Фитон XXI, 2013. Вып. 1. - С. 204-206.

940. Савиикий Р.М., Лебедева Н.В. Кулики в окрестностях озера Маныч-Гудило // Рус. орнитол. журн. - 2013. - Т. 22, № 953. - С. 3504-3505.

941. Савиикий P.M., Матишов Г.Г. Экология лутка Mergus albellus в зимний период в Азовском море // Экология. - 2011. - № 3. - С. 237-240.

942. Савиикий Р.М., Ермолаев А.И., Савиикая С.С. Современное распространение и охрана белого аиста (Ciconia ciconia) в Ростовской области // Беркут. - 2015. - Т. 24, вып. 1. - С. 37-41.

943. Савичкий P.М., Лебедева Н.В., Ломадзе Н.Х. Экология ходулочника (Himantopus himantopus) в меняющихся гидрологических условиях среды на Западном Маныче // Экология птиц: виды, сообщества, взаимосвязи: Тр. науч. конф., посвященной 150 -летию со дня рождения Н.Н. Сомова (1863-1923), 1-4 дек. 2011 г., г. Харьков, Украина: В 2-х кн. - Харьков: Изд-во Харьковского гос. ун-та, 2011. - Кн. 2. - С. 200203 (Сомовская библиотека. Вып. 1. Экология птиц: виды, сообщества, взаимосвязи).

944. Савиикий Р.М., Лебедева Н.В., Ломадзе Н.Х. Влияние гидрологического режима на пространственное распределение колоний ходулочника // Теоретические аспекты колониальности у птиц. Ростов н/Д.: Изд-во ЮНЦ РАН, 2012. - С. 223-227.

945. Статистическая оценка морфологических структур большой синицы (Parus major L.) различных природных зон / M.A. Микляева, Л.Ф. Скрылева, Н.В. Лебедева, А.В. Тихомирова // Вестн. Тамбовского ун-та. Сер. Естеств. и техн. науки. - 2013. - Т. 18, вып. 3. - С. 808-813.

946. Томкович П.С., Лебедева Н.В. Предисловие // Кулики Северной Евразии: экология, миграции и охрана: Матер. VIII Междунар. науч. конф. (10-12 ноября 2009 г., Ростов-на-Дону). - Ростов н/Д.: Изд-во ЮНЦ РАН, 2011. - С. 7-9.

947. Управление популяцией кряквы (Anas platyrhynhos) в местах проведения охоты / Н.Х. Ломадзе, Н.В. Лебедева, С.Г. Коломейцев, В.Н. Говорунов, В.В. Куликов // Гусеобразные Северной Евразии: 
география, динамика и управление популяциями: Тез. докл. Междунар. конф. (24-29 марта 2011 г., г. Элиста, Республика Калмыкия, Россия). Элиста: Б.и., 2011. С. 50-51.

948. Шавыкин А.А., Краснов Ю.В. Мониторинг птиц в северных морях // Птицы северных и южных морей России: фауна, экология. Апатиты: Изд-во КНЦ РАН, 2013. - С. 178-209.

949. Coulson S., Lebedeva N. Flying without wings // International Innovation. - 2013. - № 3. - P. 98-101.

950. Goryaev Yu.I., Goryaeva A.A., Tatarinkova L.P. Large gulls in man-made landscapes of the Western Murman (Kola Peninsula) // Berkut. Ukrainian Ornithol. J. - 2011. - № 1-2. - P. 90-110.

951. Krasnov Yu.V. Main lines of seabird research of Murmansk Marine Biological Institute in Arctic seas of Europe // Berichte zur Polarforschung. - 2012. - № 640. - P. 118-128.

952. Lebedeva N.V. Avian vector of soil mites in the High Arctic // XIV International Congress of Acarology (13-18, July, 2014, Kyoto, Japan): Abstr. book. - Kyoto, 2014. - P. 69.

953. Lebedeva N.V., Ermolaev A.I. Colonial nesting of Red footed falcon Falco vespertinus L. in near lake Manych Gudilo // Arid Ecosystems. 2012. - Vol. 2, № 3. - C. 177-185. - Doi: 0.1134/S2079096112030092

954. Lebedeva N.V., Ermolaev A.I., Lomadze N.Kh. Change of habitat preferences of the Common Kestrel: dynamic of the process, possible causes, benefits // Ornithol. Sci. - 2014. - Vol. 13. - P. 406.

955. Lebedeva N.V., Lomadze N.Kh., Kolomeitsev S.G. An experiment on maintaining the abundance and conservation of populations of waterfowl in Southern European Russia // Waterfowl of northern Eurasia: research, conservation, and sustainable use: Abstr. book of Intern. Conf. (30 November6 December 2015, Salekhard, Russia). - Salekhard, 2015. - P. 149.

956. Multicolony tracking reveals the winter distribution of a pelagic seabird on an ocean basin scale / M. Frederiksen, B. Moe, F. Daunt, R.A. Phillips, R.T. Barrett, M.I. Bogdanova, T. Boulinier, J.W. Chardine, O. Chastel, L.S. Chivers, $S$. Christensen-Dalsgaard, C. Clément-Chastel, K. Colhoun, R. Freeman, A.J. Gaston, J. González-Solís, A. Goutte, D. Grémillet, T. Guilford, G.H. Jensen, Y. Krasnov, S.-H. Lorentsen, M.L. Mallory, M. Newell, B. Olsen, D. Shaw, H. Steen, H. Strøm, G.H. Systad, T.L. Thórarinsson, T. Anker-Nilssen // Diversity and distributions: J. Conservation Biogeography. 2012. - № 18. P. 530-542. - Doi: 10.1111/j.1472-4642.2011.00864.x - URL: http://onlinelibrary. wiley.com/doi/10.1111/j.1472-4642.2011.00864.x/abstract

957. Results of observations of migration and seasonal movements of sea ducks from aboard ships on the northern sea route / Yu.V. Krasnov, 
A.V. Ezhov, Yu.I. Goryaev, Yu.A. Badanin // Waterfowl of northern Eurasia: research, conservation, and sustainable use: Abstr. Book of Intern. Conf. (30 November-6 December 2015, Salekhard, Russia). - Salekhard, 2015. P. 195-196. - URL: http://onlinereg.ru/Salekhard2015/Salekhard2015_abstracts.pdf

958. Savitskii R.M., Matishov G.G. Winter ecology of the smew (Mergus albellus) in the Sea of Azov // Russian J. Ecology. - 2011. - Vol. 42, № 3. P. 260-262.

\section{МОРСКИЕ МЛЕКОПИТАЮЩИЕ}

959. Анализ результатов мониторинга беломорской популяции гренландского тюленя / Н.Д. Гайденок, П.Р. Макаревич, Г.Н. Огнетов, Г.М. Чмаркова // Рыбное хозяйство. - 2012. - № 2. - С. 67-72.

960. Вольерный комплекс для содержания и исследования морских млекопитающих / А.С. Гладких, Н.Н. Кавцевич, А.М. Калинин, А.Л. Михайлюк // Всероссийская научно-техническая конференция и выставка, посвященная итогам реализации федеральной целевой программы «Исследования и разработки по приоритетным направлениям развития научно-технологического комплекса России на 2007-2013 годы»: Тез. докл. - М.: МИСиС, 2013. - С. 111-112.

961. Гайденок Н.Д., Макаревич П.Р., Огнетов Г.Н. Некоторые особенности обработки результатов мониторинга беломорской популяции гренландского тюленя (Phoca groenlandica) // Рыбное хозяйство. 2012. - № 3. - С. 50-53.

962. Желудкова А.И. Особенности поведения неполовозрелых особей белухи (Delphinapterus leucas) в Соловецком репродуктивном скоплении в Белом море // Морские млекопитающие Голарктики 2012: Сб. науч. тр. по матер. VII Междунар. конф. (г. Суздаль, 24-28 сентября 2012 г.). - М.: РОО «Совет по морским млекопитающим», 2012. T. 1. - C. 245-248.

963. Зырянов C.В., Кавиевич Н.Н. Обыкновенный тюлень // Красная книга Мурманской области. Изд. 2-е. - Кемерово: Азия-Принт, 2014. 2014. - С. 565-566.

964. Исследование арктических видов млекопитающих и перспективы их использования в составе биотехнических систем (БТС) / Д.Г. Ишкулов, А.Л. Михайлюк, А.А. Зайцев, М.В. Пахомов // Стратегия морской деятельности России и экономика природопользования в Арктике: Матер. IV Bcepoc. мор. науч.-практ. конф., Мурманск, 07-08 июня 2012 г. Мурманск: Изд-во Мурм. гос. техн. ун-та, 2012. - С. 129-131. 
965. Исследования атлантического моржа в юго-восточной части Баренцева моря в 2011 г. / В.С. Семенова, А.Н. Болтунов, В.В. Никифоров, B.Н. Светочев // Морские млекопитающие Голарктики 2012: Сб. науч. тр. по матер. VII Междунар. конф. (г. Суздаль, 24-28 сентября 2012 г.). М.: РОО «Совет по морским млекопитающим», 2012. - Т. 2. - С. 228-234.

966. Иикулов Д.Г., Михайлюк А.Л., Пахомов М.В. Опыт лаборатории биотехнических систем в работе с арктическими ластоногими: от теории до практики // Вестн. Кольского науч. центра РАН. - 2015. № 2(21). - С. 70-77.

967. Кавцевич Н.Н., Ерохина И.А. Серый тюлень атлантический // Красная книга Мурманской области. Изд. 2-е. - Кемерово: АзияПринт, 2014. - С. 566-567.

968. Кавиевич Н.Н., Березина И.А., Ерохина И.А. Биотехнические характеристики арктических тюленей в связи с их служебным использованием // Современные эколого-биологические и химические исследования, техника и технология производств: Матер. Междунар. науч.-практ. конф., Мурманск, 7 апреля 2015 г. В 2-х ч. - Мурманск: Изд-во Мурм. гос. техн. ун-та, 2015. - Ч. 1. - С. 111-116.

969. Кондаков А.А., Кавиевич Н.Н., Олейников Е.П. Минимальная численность серых тюленей (Halichoerus grypus Fabricius, 1791) в размножающихся колониях Айновых островов // Арктическое морское природопользование в XXI веке - современный баланс научных традиций и инноваций (к 80-летию ММБИ КНЦ РАН): Тез. докл. Междунар. науч. конф. (г. Мурманск, 1-3 апреля 2015 г.). - Апатиты: Изд-во КНЦ РАН, 2015. - С. 109-110.

970. Кондаков А.А., Светочева О.Н., Светочев В.Н. Современные проблемы изучения и охраны популяции атлантического моржа Odebenus rosmarus rosmarus L., 1758 на восточной границе ареала // Териофауна России и сопредельных территорий: Матер. Междунар. совещ. (IX Съезд териологического общества при РАН). - М.: Тов-во науч. изд. КМК, 2011. - С. 240.

971. Краснов Ю.В. Аномальные миграции гренландского тюленя в Белом море: экологические и социальные аспекты // Биологические ресурсы Белого моря: изучение и использование. - СПб.: Изд. Зоол. ин-та РАН, 2012. - С. 286-293. (Исследования фауны морей. Т. 69(77).

972. Матишов Г.Г. Морские биотехнические системы. Служебное использование морских млекопитающих // Подводные технологии и средства освоения Мирового океана. - М.: Изд. дом «Оружие и технологии», 2011. - С. 760-771.

973. Матишов Г.Г., Войнов В.Б., Михайлюк А.Л. Морские млекопитающие Арктики в составе биотехнических систем // Вестн. Южного науч. центра РАН. - 2014. - Т. 10, № 2. - С. 65-74. 
974. Матишов Г.Г., Войнов В.Б., Михайлюк А.Л. Руководство по подготовке морских млекопитающих в составе биотехнических систем в Арктике. - Ростов н/Д.: Изд-во ЮНЦ РАН, 2015. - 212 с.

975. Матишов Г.Г., Горяев Ю.И., Ишкулов Д.Г. Белый медведь Карского моря. Результаты экспедиционных работ ММБИ в районе прохождения трасс Севморпути в 1997-2013 гг. - Ростов н/Д.: Изд-во ЮНЦ РАН, 2013. - 112 c.

976. Матишов Г.Г., Кондаков А.А., Кавиевич Н.Н. Атомные ледоколы как платформа наблюдений за белым медведем (Ursus maritimus) // Наземные и морские экосистемы. - M.: Paulsen, 2011. - С. 257-262.

977. Михайлюк А.Л. Отлов, приручение и обучение морских млекопитающих выполнению служебных задач // Морские животные на службе человеку: Матер. науч.-практ. семинара (4 октября 2010 г., Североморск). - Ростов н/Д.: Изд-во ЮНЦ РАН, 2011. - С. 34-40.

978. Морские млекопитающие и белый медведь Карского моря: обзор современного состояния / А.Н. Болтунов, Я.И. Алексеева, С.Е. Беликов, В.В. Краснова, В.С. Семенова, В.Н. Светочев, О.Н. Светочева, А.Д. Чернеикий. - М.: РОО «Совет по морским млекопитающим»; ВОО «Рус. геогр. общ-во», 2015. - 104 с.

979. Оценка численности белого медведя (Ursus maritimus) по данным многолетних судовых учетов / Г.Г. Матишов, Н.Г. Челиниев, Ю.И. Горяев, П.Р. Макаревич, Д.Г. Иикулов // Докл. РАН. - 2014. T. 458, № 6. - С. 706-710.

980. Результаты спутникового мечения атлантических моржей (Odobenus rosmarus rosmarus) в юго-восточной части Баренцева моря в 2012-2014 гг. / В.С. Семенова, А.Н. Болтунов, В.В. Никифоров, М.В. Бабушкин, В.Н. Светочев // Морские млекопитающие Голарктики: Сб. науч. тр. VIII Междунар. конф. (г. Санкт-Петербург, 22-27 сентября 2014 г.). - М.: РОО «Совет по морским млекопитающим», 2015. T. 2. - C. 168-174.

981. Родительское поведение белух (Delphinapterus leucas) в естественных условиях / В.В. Краснова, А.Д. Чернеикий, А.И. Желудкова, В.М. Белькович // Изв. РАН. Сер. биол. - 2014. - № 4. - С. 365-373.

982. Светочев В.Н. Организация мониторинга местонахождения морских млекопитающих и параметров окружающей среды в естественных условиях обитания животных // Морские животные на службе человеку: Матер. науч.-практ. семинара (4 октября 2010 г., Североморск). Ростов н/Д.: Изд-во ЮНЦ РАН, 2011. - С. 41-46.

983. Светочев B.H. О миграциях гренландских тюленей (Phoca groenlandica) беломорской популяции на первом году жизни // Глобальные 
климатические процессы и их влияние на экосистемы арктических и субарктических регионов: Тез. докл. Междунар. науч. конф. (г. Мурманск, 9-11 ноября 2011 г.). - Апатиты: Изд-во КНЦ РАН, 2011. - С. 175-177.

984. Светочев В.Н. Морские млекопитающие и перспективы их рационального использования на европейском севере России // Стратегия морской деятельности России и экономика природопользования в Арктике: Матер. IV Всерос. морской науч.-практ. конф., Мурманск, 7-8 июня 2012 г. - Мурманск: Изд-во Мурм. гос. техн. ун-та, 2012. - С. 137.

985. Светочев B.Н. Биология и экология гренландского тюленя (Phoca groenlamdica Erxleben, 1777) беломорской популяции на первом году жизни: Автореф. дис. ... канд. биол. наук (25.00.28 - океанология). Мурманск, 2013. - 24 с.

986. Светочев В.Н., Кавцевич Н.Н. Сезонное распределение гренландских тюленей (Phoca groenlandica) беломорской популяции на первом году жизни // Дистанционные методы исследования в зоологии: Матер. науч. конф. (28-29 ноября 2011 г., г. Москва, ИПЭЭ РАН). - М.: Тов-во науч. изд. КМК, 2011. - С. 82.

987. Светочев B.H., Светочева О.Н. Изучение морских млекопитающих в Белом море методом спутниковой телеметрии: результаты и перспективы // Морские млекопитающие Голарктики 2012: Сб. науч. тр. по материалам VII Междунар. конф. (г. Суздаль, 2428 сентября 2012 г.). - М.: РОО «Совет по морским млекопитающим», 2012. - T. 2. - C. 209-213.

988. Светочев В.Н., Светочева О.Н. Морские млекопитающие: биология, питание, запасы // Биологические ресурсы Белого моря: изучение и использование. - СПб.: Изд. Зоол. ин-та РАН, 2012. С. 261-286 (Исследования фауны морей. Т. 69(77).

989. Светочев B.H., Светочева О.Н. Летняя миграционная активность белухи (Delphinapterus leucas) в Двинском заливе Белого моря // Докл. РАН. - 2013. - Т. 448, № 1. - С. 113-117.

990. Светочев В.Н., Светочева О.Н. Особенности распределения и межвидовых взаимоотношений нерпы (Pusa hispida) и морского зайца (Erignathus barbatus) в Белом море в безледовый период // Поведение и поведенческая экология млекопитающих: Матер. 3-й науч. конф. (Черноголовка, 14-18 апреля 2014 г.). - М.: Тов-во науч. изд. КМК, 2014. - С. 111.

991. Светочев В.Н., Светочева О.Н. Питание и пищевые отношения настоящих тюленей в Белом море // Вестн. Кольского науч. центра PAH. - 2015. - № 3(23). - C. 93-101.

992. Светочев В.Н., Светочева О.Н. Уязвимость настоящих тюленей в Арктике в современных климатических и антропогенных условиях // 
Программа и материалы международной научной конференции, посвященной 50-летию Зоологического музея им. М.И. Глобенко Таврической академии Крымского федерального университета им. В.И. Вернадского (Симферополь, 16-18 сентября 2015 г.). Симферополь: Б.и., 2015. - С. 102-103.

993. Светочев В.Н., Кавиевич Н.Н., Светочева О.Н. Миграции морского зайца (Erignathus barbatus) летом и осенью 2014 г. в Онежском заливе Белого моря // Современные эколого-биологические и химические исследования, техника и технология производств: Матер. Междунар. науч.-практ. конф., Мурманск, 7 апреля 2015 г.: В 2-х ч. - Мурманск: Изд-во Мурм. гос. техн- ун-та, 2015. - Ч. 1. - С. 259-264.

994. Светочев В.Н., Кавцевич Н.Н., Светочева О.Н. Результаты разработки экспериментального образца биотехнической системы. Спутниковое мечение морского зайца в Белом море // Экология, экономика, информатика: В 3-х т. Т. 3. Геоинформационные технологии и космический мониторинг. - Ростов н/Д.: Изд-во Южного фед. ун-та, 2015. - С. 195-199.

995. Светочев B.Н., Светочева О.Н., Кавцевич Н.Н. Метод спутниковой телеметрии для мониторинга морских млекопитающих в Белом море // Программа и материалы международной научной конференции, посвященной 50-летию Зоологического музея им. М.И. Глобенко Таврической академии Крымского федерального университета им. В.И. Вернадского (Симферополь, 16-18 сентября 2015 г.). - Симферополь: Б.и., 2015. - С. 104-105.

996. Светочев В.Н., Светочева О.Н., Кавцевич Н.Н. Миграции гренландских тюленей беломорской популяции на первом году жизни по данным спутниковой телеметрии // Междунар. журн. приклад. и фундамент. исследований. - 2015. - № 12-3. - C. 485-491. - URL: http:// $\mathrm{rae} . \mathrm{ru} / \mathrm{upfs} /$ ? section $=$ content $\&$ op $=$ articles $\&$ month $=12 \&$ year $=2015 \& \mathrm{part}=3$

997. Светочева О.Н. Проникновение редких видов морских млекопитающих в Белое море с 1985 по 2010 гг. // Глобальные климатические процессы и их влияние на экосистемы арктических и субарктических регионов: Тез. докл. Междунар. науч. конф. (г. Мурманск, 9-11 ноября 2011 г.). - Апатиты: Изд-во КНЦ РАН, 2011. - С. 177-178.

998. Светочева O.H. О питании нерпы (Phoca hispida) колюшками (Gasterosteidae) в Белом море // Морские млекопитающие Голарктики 2012: Сб. науч. тр. по матер. VII Междунар. конф. (г. Суздаль, 24-28 сентября 2012 г.). - М.: РОО «Совет по морским млекопитающим», 2012. - T. 2. - C. 218-221.

999. Светочева О.Н. Питание морского зайца (Erignathus barbatus) в Белом море // Проблемы изучения и охраны животного мира на Севере: Матер. II Всерос. науч. конф. с междунар. участием (8-12 апреля 2013 г., г. Сыктывкар, Республика Коми, Россия). - Сыктывкар: Изд-во Коми НЦ УрО РАН, 2013. - С. 181-183. 
1000. Светочева О.Н. Мониторинг пагетодных видов настоящих тюленей в современных климатических и антропогенных условиях в Белом, Баренцевом и Карском морях // Современные экологобиологические и химические исследования, техника и технология производств: Матер. Междунар. науч.-практ. конф., Мурманск, 7 апреля 2015 г.: В 2-х ч. - Мурманск: Изд-во Мурм. гос. техн. ун-та, 2015. - Ч. 1. - С. 265-270.

1001. Светочева О.Н., Светочев В.Н. Биологический мониторинг нерпы (Pusa hispida) в западном секторе российской Арктики и его основные параметры // Изучение и освоение морских и наземных экосистем в условиях арктического и аридного климата: Матер. Междунар. науч. конф. (6-11 июня 2011 г., Ростов-на-Дону). - Ростов н/Д.: Изд-во ЮНЦ РАН, 2011. - С. 334-337.

1002. Светочева O.Н., Светочев B.Н. Подходы белухи (Delphinapterus leucas) в Двинском заливе (Летний берег) во время сезонной миграции в Белое море // Морские млекопитающие Голарктики 2012: Сб. науч. тр. по матер. VII Междунар. конф. (г. Суздаль, 24-28 сентября 2012 г.). М.: РОО «Совет по морским млекопитающим», 2012. - Т. 2. - С. 214-217.

1003. Светочева О.Н., Светочев В.Н. Атлантический морж// Красная книга Мурманской области. Изд. 2-е. - Кемерово: АзияПринт, 2014. - C. 564-565.

1004. Светочева О.Н., Светочев В.Н. Особенности биологии детенышей гренландского тюленя беломорской популяции (Phoca groenlandica Erxleben, 1777) на разных стадиях развития // Морские млекопитающие Голарктики: Сб. науч. тр. VIII Междунар. конф. (Санкт-Петербург, 22-27 сентября 2014). - М.: РОО «Совет по морским млекопитающим», 2015. - Т. 2. - С. 153-160.

1005. Светочева О.Н., Светочев В.Н., Кавцевич Н.Н. Изучение экологии пагетодных тюленей и белухи методом спутниковой телеметрии в Белом море // Евразийское науч. объединение. - 2015. - Т. 1, № 5(5). C. $41-45$.

1006. Спутниковое мечение щенков гренландского тюленя в 2010 году / Г.Г. Матишов, В.Н. Светочев, Н.Н. Кавцевич, Д.Г. Иикулов // Морские животные на службе человеку: Матер. науч.-практ. семинара (4 октября 2010 г., Североморск). - Ростов н/Д.: Изд-во ЮНЦ РАН, 2011. - C. 47-52.

1007. Судовые наблюдения морских млекопитающих на маршруте Северодвинск-Бугрино (о. Колгуев) в 2011 г. / В.С. Семенова, А.Н. Болтунов, B.B. Никифоров, B.Н. Светочев // Морские млекопитающие Голарктики 2012: Сб. науч. тр. по матер. VII Междунар. конф. (г. Суздаль, 2428 сентября 2012 г.). - М.: РОО «Совет по морским млекопитающим», 2012. - T. 2. - C. 225-228. 
1008. Трошичев A.P. К вопросу о транспортировке ластоногих // Арктическое морское природопользование в XXI веке - современный баланс научных традиций и инноваций (к 80-летию ММБИ КНЦ РАН): Тез. докл. Междунар. науч. конф. (г. Мурманск, 1-3 апреля 2015 г.). Апатиты: Изд-во КНЦ РАН, 2015. - С. 225-226.

1009. Челинцев Н.Г., Горяев Ю.И., Ежов А.В. Расчет численности белых медведей в восточной части Баренцева моря и юго-западной части Карского моря по результатам многолетних наблюдений с ледоколов // Морские млекопитающие Голарктики: Сб. науч. тр. VIII Междунар. конф. (Санкт-Петербург, 22-27 сентября 2014). - М.: РОО «Совет по морским млекопитающим», 2015. - Т. 2. - С. 274-283.

1010. Error patterns in age estimation of harp seals (Pagophilus groenlandicus): results from a transatlantic image-based blind reading experiment using known-age teeth / A.K. Frie, K.-A. Fagerheim, M.O. Hammill, F.O. Kapel, C. Lockyer, G.B. Stenson, A. Rosing-Asvid, V. Svetochev // ICES. - 2011. - Vol. 68(9). - P. 1942-1953.

1011. Error patterns in age estimation and toothreadability assignment of grey seals (Halichoerus grypus): results from a transatlantic, image-based, blind-reading study using known-age animals / A.K. Frie, M.O. Hammill, E. Hauksson, Y. Lind, C. Lockyer, O. Stenman, O. Svetocheva // ICES. 2013. - Vol. 70, № 2. - P. 418-430. - Doi:10.1093./icesjms/fss169

1012. Greenland Sea hooded seals - a climate change loser? / A.K. Frie, V. Svetochev, G.B. Stenson, T. Haug // Arctic Frontiers 2015. Climate and Energy: Abstr. Sci. conf. (Tromsø, Norway, 18-23 January 2015). Tromsø, 2015. P. 170. - URL: www.arcticfrontiers.com.; http://arcticfrontiers. conference-sevices.net/reports/template/onetextabstract.xml?xsl=template/ onetextabstract. $x s 1 \&$ conferenceID $=4282 \&$ abstractID $=866400$

1013. Matishov G.G., Ognetov G.N. White whale (Delphinapterus leucas) of the Russia Arctic Seas: biology, ecology, protection and exploitation of resources. - Spain: Fundación Ciudad de las Artes y las Ciencias (Comunitat Valencuiana), 2011. - 302 c.

1014. Reproductive parameters of Greenland Sea hooded seal (Cystophora cristata) females 1958-1999 - clues to the lack of population recovery? / A.K. Frie, V. Svetochev, G. Stenson, T. Haug // ICES. Annual Science Conference, Sess. Climate change: Back to the future for marine predators (19 September 2014, Corina, Spain). - Corina, 2014. - P. 96-97.

1015. Svetochev $V$. Seasonal distribution of the White Sea population harp seal (Phoca groenlandica) on the first year of life // Joint ICES/NAFO Working Group on Harp and Hooded Seals SMRU, University of St. Andrews, UK, 15-18 August 2011, WP SEA-200. - 2011. - P. 12. 
1016. Svetocheva O.N., Svetochev V.N. Analysis of seasonality in trophic relationships of true seals (Phocideae) in the White Sea // Czech Polar Reports. - 2015. - Vol. 5, iss. 2. - P. 230-240. - Doi: 10.5817/CPR2015-2-20

\section{ПАРАЗИТОЛОГИЯ}

1017. Извекова Г.И., Куклина М.М. Заражение цестодами и активность пищеварительных гидролаз позвоночных хозяев // Успехи современной биологии. - 2014. - Т. 134, № 3. - С. 304-315.

1018. Куклин В.В. Особенности гельминтофауны серебристых чаек синантропной группировки г. Мурманска // Докл. РАН. - 2011. T. 440, № 3. - С. 426-429.

1019. Куклин B.B. Влияние процессов синантропизации на гельминтофауну морских птиц на примере серебристых чаек г. Мурманска // Материалы V Всероссийской конференции с международным участием по теоретической и морской паразитологии (23-27 апреля 2012 г., Светлогорск, Калининградская обл.). - Калиниград: Изд. АтлантНИРО, 2012. - C. 115-117.

1020. Куклин B.B. Гельминтофауна моевки (Rissa trydactyla) Баренцева моря // Зоол. журн. - 2013. - Т. 92, № 7. - С. 781-789.

1021. Куклин В.В. Модифицированная методика изготовления тотальных препаратов паразитических плоских червей // Рос. паразитол. журн. - 2013. - № 4. - С. 66-67.

1022. Куклин В.В. Особенности гельминтофауны птиц открытой акватории Баренцева моря // Рос. паразитол. журн. - 2013. - № 3. C. 16-21.

1023. Куклин В.В. Особенности функционирования паразитарных систем в прибрежье Баренцева моря в зимний период // Современные проблемы экологии и природопользования: Матер. регион. науч.-практ. конф., посвященной 15-летию со дня основания кафедры биоэкологии, Мурманск, 27-28 февраля 2014 г. - Мурманск: Изд-во Мурм. гос. техн. ун-та, 2014. - С. 112-115.

1024. Куклин В.В. Гельминты массовых видов колониальных птиц Мурманского побережья: комплексный и сравнительный анализ // Арктическое морское природопользование в XXI веке - современный баланс научных традиций и инноваций (к 80-летию ММБИ КНЦ РАН): Тез. докл. Междунар. науч. конф. (г. Мурманск, 1-3 апреля 2015 г.). Апатиты: Изд-во КНЦ РАН, 2015. - С. 123-125. 
1025. Куклин B.В. Особенности гельминтофауны морских птиц и реализации жизненных циклов паразитов в прибрежье Мурмана (Баренцево море) в зимний период // Докл. РАН. - 2015. - Т. 461, № 5. C. 612-615.

1026. Куклин В.В., Куклина М.М. Гельминтофауна птиц Баренцева и Карского морей и взаимоотношения в системе гельминты-морские птицы // Птицы северных и южных морей России: фауна, экология. Апатиты: Изд-во КНЦ РАН, 2013. - С. 159-177.

1027. Куклин В.В., Куклина М.М. Эколого-паразитологические исследования рыбоядных птиц Восточного Приазовья // Птицы северных и южных морей России: фауна, экология. - Апатиты: Изд-во КНЦ РАН, 2013. - C. 254-261.

1028. Куклин В.В., Маслич М.А. Паразитофауна ракообразных семейства Gammaridae Мурманского побережья Баренцева моря // Докл. РАН. - 2011. - Т. 437, № 5. - С. 709-713.

1029. Куклин В.В., Галактионов К.В., Краснов Ю.В. Возрастные и пространственные особенности заражения гельминтами в колониях моевок острова Харлов (Восточный Мурман, Баренцево море) // Теоретические аспекты колониальности у птиц. - Ростов н/Д.: Изд-во ЮНЦ РАН, 2012. - С. 192-198.

1030. Куклин В.В., Куклина М.М., Кисова Н.Е. Видовой состав и сезонная динамика гельминтофауны европейского керчака (Myoxocephalus scorpius, Cottidae) в Кольском заливе Баренцева моря // Зоол. журн. 2012. - T. 91, № 2. - С. 131-137.

1031. Куклина М.M. Взаимоотношения в системе паразит-хозяин на примере Diphyllobothrium dendriticum (Cestoda: Diphyllobothriidae)серебристая чайка Larus argentatus // Докл. РАН. - 2015. - Т. 463, № 1. - С. 116-119.

1032. Лебедева Н.В. Панцирные клещи (Acari, Oribatida) в гнездах дендрофильных птиц в степной зоне на юге европейской России // Энергетика и годовые циклы птиц: Матер. Междунар. конф. памяти В.Р. Дольника. - М.: Тов-во науч. изд. КМК, 2015. - С. 177-179.

1033. Лебедева Н.В., Мелехина Е.Н., Гвяздович Д.Я. Новые данные о почвенных клещах в гнездах бургомистра Larus hyperboreus L. на архипелаге Шпицберген // Вестн. Южного науч. центра РАН. 2012. - T. 8, № 1. - С. 70-75.

1034. Лебедева Н.В., Мелехина Е.Н., Лебедев В.Д. Панцирные клещи в местообитаниях и гнездах пуночки в высокой Арктике // Комплексные исследования природы Шпицбергена и прилегающего шельфа: Матер. Междунар. науч. конф. (Мурманск, 6-8 ноября 2014 г.). Вып. 12. - М.: ГЕОС, 2014. - C. 162-168. 
1035. First record of Vulgarogamasus immanis (Acari, Mesostigmata) in Svalbard / D.J. Gwiazdowicz, T. Solhøy, S.J. Coulson, N.V. Lebedeva, E.N. Melekhina // Polish Polar Res. - 2012. - Vol. 33, № 1. - P. 35-39.

1036. Korneva J.V., Jones M.K., Kuklin V.V. Fine structure of the uterus in tapeworm Tetrabothrius erostris (Cestoda: Tetrabothriidae) // Parasitology Res. - 2014. - № 113. - P. 4623-4631. - Doi: 10.1007/s00436-014-4153-9

1037. Korneva Ja.V., Jones M.K., Kuklin V.V. Fine structure of the copulatory apparatus of the tapeworm Tetrabothrius erostris (Cestoda: Tetrabothriidea) // Parasitology Res. - 2015. - Vol. 114, № 5. - P. 1829-1838.

1038. Kuklin V.V. Seabird helminth fauna and parasite life cycles on the Murman coast of the Barents Sea in winter // Doklady Biol. Sci. - 2015. Vol. 461, № 1. - P. 100-103.

1039. Kuklina M.M. Relationship in the parasite-host system as exemplified by the Diphyllobothrium dendriticum (Cestoda: Diphyllobothriidae)-herring gull Larus argentatus // Doklady Biol. Sci. - 2015. - Vol. 463, № 1. - P. 183-185.

1040. Relationships between uterus and eggs in cestodes from different taxa, as revealed by scanning electron microscopy / J.V. Korneva, S.A. Kornienko, V.V. Kuklin, N.M. Pronin, M.K. Jones // Parasitology Res. 2014. - № 113. - P. 425-432. - Doi: 10.1007/s00436-013-3671-1 - URL: http://link.springer.com/article/10.1007/s00436-013-3671-1

\section{Физиология и Биохимия}

1041. Березина И.А. Исследование поведения настоящих тюленей в условиях неволи: Автореф. дис. ... канд. биол. наук (03.02.04 зоология). - Петрозаводск, 2013. - 23 с.

1042. Березина И.А., Кавиевич Н.Н. Распознавание серыми тюленями зрительных раздражителей // Изв. Самар. науч. центра РАН. 2011. - Т. 13, № 1(5). - С. 1052-1056.

1043. Березина И.А., Кавцевич Н.Н. Исследование поведения и сенсорных систем арктических тюленей на установке «Экспериментальный научно-исследовательский комплекс "Мурманский океанариум"» // Всероссийская научно-техническая конференция и выставка, посвященная итогам реализации федеральной целевой программы «Исследования и разработки по приоритетным направлениям развития научнотехнологического комплекса России на 2007-2013 годы»: Тез. докл. М.: МИСиС, 2013. - С. 112-113.

1044. Березина И.А., Калинин А.М., Кавцевич Н.Н. Различение настоящими тюленями геометрических фигур [Электронный ресурс] // 
Наука и образование - 2011: Матер. Междунар. науч.-техн. конф. Электрон. текст. дан. (30 Мб). - Мурманск: Изд-во Мурм. гос. техн. ун-та, 2011. - C. 541-548. - 1 электрон. опт. диск (CD-ROM). - Систем. требования: PC не ниже класса Pentium II; 128 Mb RAM; свободное место на HDD 30 Мб; дисковод CD-ROM 2-х и выше; - Загл. с экрана. - Электрон. текст подг. ФГБОУ ВПО «МГТУ». - № гос. регистрации 0321100504.

1045. Березина И.А., Калинин А.М., Клапатюк А.М. Этологические наблюдения за ластоногими, содержащимися в условиях океанариума, и различение настоящими тюленями геометрических фигур с измененной площадью креста [Электронный ресурс] // Наука и образование - 2012: Матер. Междунар. науч.-техн. конф., Мурманск, 2-6 апреля 2012 г. Электрон. текст. дан. (30 Мб). - Мурманск: Изд-во Мурм. гос. техн. ун-та, 2012. С. 319-321. - 1 электрон. опт. диск (CD-ROM). - Систем. требования: PC не ниже класса Pentium II; $128 \mathrm{Mb}$ RAM; свободное место на HDD 130 Мб; дисковод CD-ROM 2-х и выше. - Загл. с экрана. - Электрон. текст подг. ФГБОУ ВПО «МГТУ». - № гос. регистрации 0321201101.

1046. Березина И.А., Калинин А.М., Трошичев А.Р. Распознавание звуков различной частоты настоящими тюленями // Материалы XXIX конференции молодых ученых Мурманского морского биологического института, посвященной 140 -летию со дня рождения Г.А. Клюге, «Морские исследования экосистем европейской Арктики» (г. Мурманск, май 2011 г.). - Мурманск: Изд. ММБИ КНЦ РАН, 2011. - С. 11-16.

1047. Биоэкологические аспекты защитных реакций рыб и беспозвоночных / Н.Г. Журавлева, Г.Г. Матишов, О.Н. Оттесен, E.E. Минченок. - Апатиты: Изд-во КНЦ РАН, 2011. - 272 с.

1048. Биоэкологические основы жизнедеятельности организмов в условиях Заполярья / Н.Г. Журавлева, Г.Г. Матишов, О. Оттесен, Е.Н. Будилова, А.В. Троиенко, Т.М. Ларина. - Апатиты: Изд-во КНЦ PAH, 2013. $-210 \mathrm{c}$.

1049. Биоэкологические аспекты защитных реакций рыб и беспозвоночных / Г.Г. Матииов, Н.Г. Журавлева, О. Оттесен, Е.Е. Минченок. Изд. 2-е доп. и перераб. - Мурманск: Изд-во Мурм. гос. техн. ун-та, 2013. $-260 \mathrm{c}$.

1050. Вербицкий E.В., Войнов В.Б. К экологической значимости физиологической реактивности организма морских млекопитающих // Изучение и освоение морских и наземных экосистем в условиях арктического и аридного климата: Матер. Междунар. науч. конф. (6-11 июня 2011 г., Ростов-на-Дону). - Ростов н/Д.: Изд-во ЮНЦ РАН, 2011. - C. 249-251.

1051. Вербиикий Е.В., Войнов В.Б., Кибальников А.С. Феномен апноэ сна ушастых и настоящих тюленей // Актуальные проблемы сомнологии: Тез. докл. VIII Всерос. конф. (22-23 ноября 2012 г., Москва). - М.: Б.и., 2012. - С. 24-25. 
1052. Войнов В.Б. Подходы к оценке физической и психоэмоциональной работоспособности подводников в условиях Заполярья // Морские животные на службе человеку: Матер. науч.-практ. семинара (4 октября 2010 г., Североморск). - Ростов н/Д.: Изд-во ЮНЦ РАН, 2011. - C. 66-70.

1053. Войнов В.Б. Современные аппаратные средства дистанционного контакта с животными // Проблемные вопросы служебной кинологии на современном этапе: Матер. IV науч.-практ. конф. - Ростов н/Д.: ФГКОУ ДПО РШ СРС МВД России, 2015. - С. 49-53.

1054. Войнов В.Б., Вербиикий Е.В. Параметры физиологической реактивности морских млекопитающих как важный компонент экологических исследований // Экологическая безопасность приморских регионов (порты, берегозащита, рекреация, марикультура): Матер. Междунар. науч. конф., посвященной 150-летию Н.М. Книповича (Ростов-на-Дону, 5-8 июня 2012 г.). - Ростов н/Д.: Изд-во ЮНЦ РАН, 2012. - C. $80-82$.

1055. Войнов В.Б., Михайлюк А.Л. Представление о доминанте как основе обучения животных // Проблемные вопросы служебной кинологии на современном этапе: Матер. II науч.-практ. конф. (16 мая 2013 г., г. Ростов-на-Дону). - Ростов н/Д.: ФГКОУ ДПО РШ СРС МВД России, 2013. - C. 3-11.

1056. Гладких А.С. Влияние седативных препаратов на сердечнососудистую систему гренландских тюленей // Материалы XXIX конференции молодых ученых Мурманского морского биологического института, посвященной 140 -летию со дня рождения Г.А. Клюге, «Морские исследования экосистем европейской Арктики» (г. Мурманск, май 2011 г.). - Мурманск: Изд. ММБИ КНЦ РАН, 2011. - С. 42-44.

1057. Гудимов А.В. Поведенческие и физиологические реакции двустворчатых моллюсков на модельные токсиканты // Материалы IV Всероссийской конференции по водной экотоксикологии, посвященной памяти Б.А. Флерова, «Антропогенное влияние на водные организмы и экосистемы» и школы-семинара «Современные методы исследования состояния поверхностных вод в условиях антропогенной нагрузки» (пос. Борок, 24-29 сентября 2011 г.): В 2-х ч. - Борок: Изд. Ин-та биол. внутр. вод им. И.Д. Папанина, 2011. - Ч. 1. - С. 100-101.

1058. Гудимов A.B. Первые записи поведенческих реакций двустворчатых моллюсков исландского гребешка Chlamys islandica и модиолуса Modiolus modiolus // Вестн. Камчат. гос. техн. ун-та. - 2012. № 20. - C. 50-55.

1059. Гудимов А.В. Поведение двустворчатых моллюсков Шпицбергена в контролируемых условиях // Вестн. Камчат. гос. техн. ун-та. - 2012. № 22. - C. 77-81. 
1060. Гудимов А.В. Поведенческие реакции двустворчатых моллюсков Шпицбергена: Chlamys islandica, Mya truncata и Tridonta borealis // Комплексные исследования природы Шпицбергена: Матер. Междунар. науч. конф. (Мурманск, 1-3 ноября 2012 г.). ВЫп. 11. - М.: ГЕОС, 2012. - C. 46-50.

1061. Гудимов А.В. Перманентная адаптация // Современные экологобиологические и химические исследования, техника и технология производств: Матер. Междунар. науч.-практ. конф., Мурманск, 7 апреля 2015 г.: В 2-х ч. - Мурманск: Изд-во Мурм. гос. техн. ин-та, 2015. Ч. 1. - C. 211-213.

1062. Гудимов А.В., Ерохина И.А. Особенности метаболизма и поведения мидий в условиях экспериментального осушения // Животные: экология, биология и охрана: Матер. Всерос. науч. конф. с междунар. участием (г. Саранск, 29 ноября 2012 г.). - Саранск: Изд-во Мордов. гос. ун-та, 2012. С. 109-112.

1063. Гудимов А.В., Нестеров В.П. Медленные ритмы как поведенческие и физиологические адаптации мидий к изменениям условий среды // Материалы XIV Международного совещания и VII школы по эволюционной физиологии: Тез. докл. и лекций (СанктПетербург, 24-29 октября 2011 г.). - СПб.: Изд. Ин-та эволюц. физиол. и биохим. им. И.М. Сеченова, 2011. - С. 61-62.

1064. Двигательная активность беспозвоночных и рыб при вариациях магнитного поля / В.М. Муравейко, И.А. Степанюк, В.С. Зензеров, A.B. Емелина // Космос и биосфера: Матер. IX Междунар. крымской конф. (10-15 октября 2011 г., г. Алушта, Крым, Украина). - Симферополь: ДИАЙПИ, 2011. - С. 143-144.

1065. Емелина A.B. Реакция краба Paralithodes camtchaticus Баренцева моря на магнитное поле // Материалы XXXI конференции молодых ученых Мурманского морского биологического института, посвященной 135-летию со дня рождения К.М. Дерюгина, «Океанография и биология арктических морей» (г. Мурманск, май 2013). - Мурманск: Изд. ММБИ КНЦ РАН, 2013. - С. 68-70.

1066. Емелина A.B. Реакция краба Paralithodes camtchaticus (Tilesius, 1815) на приближение и прохождение циклонов // Эколого-эволюционные исследования морских организмов и экосистем: Матер. XIV Междунар. науч. конф. студентов и аспирантов «Проблемы Арктического региона» (г. Мурманск, май 2014 г.). Т. І. Форум молодых ученых, посвященный 110-летию со дня рождения Ю.И. Полянского (XXXII конференция молодых ученых ММБИ). - Мурманск: Изд. ММБИ КНЦ РАН, 2014. C. 74-76. 
1067. Емелина А.В., Владимирова О.М., Фролова Н.С. Влияние вариаций магнитного поля Земли на двигательную активность краба Paralithodes camtchaticus Баренцева моря // Материалы XXX юбилейной конференции молодых ученых Мурманского морского биологического института, посвященной 150 -летию со дня рождения Н.М. Книповича, «Проблемы океанографии, биологии и освоения биоресурсов морей российской Арктики» (г. Мурманск, май 2012). - Мурманск: Изд. ММБИ КНЦ РАН, 2012. - С. 61-64.

1068. Ермилов С.Д. Лечение щенков гренландского тюленя в условиях биотехнического аквакомплекса ММБИ // Материалы XXXI конференции молодых ученых Мурманского морского биологического института, посвященной 135-летию со дня рождения К.М. Дерюгина, «Океанография и биология арктических морей» (г. Мурманск, май 2013). - Мурманск: Изд. ММБИ КНЦ РАН, 2013. - С. 72-75.

1069. Ерохина И.А. Гаптоглобин как индикатор физиологического состояния морских млекопитающих // Проблемы иммунологии, патологии и охраны здоровья рыб: Расширенные матер. III Междунар. конф. (18-22 июля 2011 г., пос. Борок). - М.: Изд-во РГАУ-МСХА им. К.А. Тимирязева, 2011. - С. 297-301.

1070. Ерохина И.А. Метаболические адаптации ластоногих в раннем постнатальном периоде развития // Адаптационные стратегии живых систем: Тез. докл. междисципл. науч. конф. (11-16 июня 2012 г., Новый Свет, Крым, Украина). - Киев: Изд-во В.С.Мартынюк, 2012. C. $41-42$.

1071. Ерохина И.А. Биохимические адаптации ластоногих в раннем постнатальном периоде развития // Современные проблемы биологии, экологии и химии: Сб. матер. III Междунар. конф., посвященной 25-летию биол. фак-та ЗНУ (11-13 мая 2012 г., г. Запорожье, Украина). Запорожье: Copy Art, 2012. - C. 264-265.

1072. Ерохина И.А. Метаболические адаптации ластоногих в раннем постнатальном периоде развития // Физиологические, биохимические и молекулярно-генетические механизмы адаптаций гидробионтов: Матер. Bсерос. конф. с междунар. участием (22-28 сент. 2012 г., пос. Борок). Борок: Изд. Ин-та биол. внутр. вод им. И.Д. Папанина, 2012. - С. 130-132.

1073. Ерохина И.А. Метаболические адаптации ластоногих в раннем постнатальном периоде развития // Актуальные проблемы современной териологии: Тез. докл. Всерос. науч. конф. (18-22 сент. 2012 г., г. Новосибирск). - Новосибирск: Сибрегион Инфо, 2012. - С. 99.

1074. Ерохина И.А. Физиолого-биохимические аспекты адаптации морских млекопитающих при содержании в океанариуме // Актуальные 
проблемы современной териологии: Тез. докл. Всерос. науч. конф. (18-22 сент. 2012 г., г. Новосибирск). - Новосибирск: Сибрегион Инфо, 2012. - C. 100 .

1075. Ерохина И.А. Новые данные к характеристике метаболического статуса тюленя-хохлача (Cystophora cristata Erxleben, 1777) и гренландского тюленя (Pagophilus groenlandica Erxleben, 1777) в раннем постнатальном периоде развития // Морские млекопитающие Голарктики 2012: Сб. науч. тр. по матер. VII Междунар. конф. (г. Суздаль, 24-28 сентября 2012 г.). - М.: РОО «Совет по морским млекопитающим», 2012. - Т. 1. C. $237-241$.

1076. Ерохина И.А. К вопросу об индикаторах физиологического состояния морских млекопитающих: сорбционная способность эритроцитов // Морские млекопитающие Голарктики 2014: Тез. докл. VIII Междунар. конф. (г. Санкт-Петербург, 24-27 сентября 2014 г.). СПб.: РОО «Совет по морским млекопитающим», 2014. - С. 29.

1077. Ерохина И.А. Физиолого-биохимические адаптации морских млекопитающих в онтогенезе // Млекопитающие Северной Евразии: жизнь в северных широтах: Матер. Междунар. науч. конф. (6-10 апреля 2014 г., г. Сургут). - Сургут: ИЦ СурГУ, 2014. - С. 51-52.

1078. Ерохина И.А. Биохимический подход в изучении популяций морских млекопитающих // Современные эколого-биологические и химические исследования, техника и технология производств: Матер. Междунар. науч.-практ. конф., Мурманск, 7 апреля 2015 г.: В 2-х ч. Мурманск: Изд-во Мурм. гос. техн. ун-та, 2015. - Ч. 1. - С. 97-104.

1079. Ерохина И.А. К вопросу об индикаторах физиологического состояния морских млекопитающих: сорбционная способность эритроцитов // Морские млекопитающие Голарктики: Сб. науч. тр. VIII Междунар. конф. (Санкт-Петербург, 22-27 сентября 2014 г.). - М.: РОО «Совет по морским млекопитающим», 2015. - Т. 1. - С. 186-191.

1080. Ерохина И.А. Некоторые свойства эритроцитов в оценке физиологического состояния морских млекопитающих // Проблемы патологии, иммунологии и охраны здоровья рыб и других гидробионтов: Расширенные матер. IV Междунар. конф., Борок, 24-27 сентября 2015 г. - Ярославль: Филигрань, 2015. - С. 517-524.

1081. Ерохина И.А. Новые данные об адсорбционно-транспортной функции эритроцитов морских млекопитающих // Арктическое морское природопользование в XXI веке - современный баланс научных традиций и инноваций (к 80-летию ММБИ КНЦ РАН): Тез. докл. Междунар. науч. конф. (г. Мурманск, 1-3 апреля 2015 г.). - Апатиты: Изд-во КНЦ РАН, 2015. - С. 65-66. 
1082. Ерохина И.А., Зензеров В.С. Влияние голодания на биохимические параметры гемолимфы камчатского краба Paralithodes camtschaticus (Tilesius, 1815) // Современные проблемы гидробиологии. Перспективы, пути и методы решений: Матер. III Междунар. науч. конф. (г. Херсон, 17-19 мая 2012 г.). - Херсон: ПП Вишемирьский B.C., 2012. - C. 234-237.

1083. Ерохина И.А., Зензеров В.С. Влияние голодания на биохимические параметры гемолимфы камчатского краба Paralithodes camtschaticus // Современные зоологические исследования в России и в сопредельных странах: Матер. II Междунар. науч.-практ. конф. памяти д.б.н., профессора М.А. Козлова. - Чебоксары: ИПК «Новое время», 2012. - C. 48-49.

1084. Ерохина И.А., Зензеров В.С. Метаболический статус камчатского краба Paralithodes camtschaticus, Tilesius, 1815 при голодании // Приволжский науч. вестн. (издатель Самохвалов А.В., Ижевск). - 2014. № 6(34). - C. 12-14.

1085. Ерохина И.А., Кавцевич Н.Н. Новые данные к характеристике метаболического статуса тюленя-хохлача (Cystophora cristata Erxleben, 1777) и гренландского тюленя (Pagophilus groenlandica Erxleben, 1777) в раннем постнатальном периоде развития // Докл. РАН. - 2011. T. 440, № 3. - C. 420-422.

1086. Ерохина И.А., Кавцевич Н.Н. Проблема охраны здоровья морских млекопитающих // Проблемы иммунологии, патологии и охраны здоровья рыб: Расширенные матер. III Междунар. конф. (18-22 июля 2011 г., пос. Борок). - М.: Изд-во РГАУ-МСХА им. К.А. Тимирязева, 2011. - C. 31-34.

1087. Жарова Ю.А., Михайлюк А.Л., Березина И.А. Изучение суточного ритма кольчатой нерпы в искусственных условиях содержания // Проблемы Арктического региона: 11-я Междунар. науч. конф. студентов и аспирантов, г. Мурманск, 12 мая 2011 г.: Тез. конф. Мурманск: Изд. ММБИ КНЦ РАН, 2011. - С. 38-39.

1088. Жарова Ю.А., Михайлюк А.Л., Березина И.А. Наблюдение изменения двигательной активноси кольчатой нерпы при воздействии на нее постоянного шума // Проблемы Арктического региона: 12-я Междунар. науч. конф. студентов и аспирантов, г. Мурманск, май 2012 г.: Тез. конф. - Мурманск: Изд. ММБИ КНЦ РАН, 2012. - С. 64-65.

1089. Желудкова А.И. Поведение кольчатой нерпы (Pusa hispida) и гренландского тюленя (Pagophilus groenlandicus) в условиях неволи [Электронный ресурс] // Наука и образование - 2013: Матер. Междунар. науч.-техн. конф., Мурманск, 4-11 марта 2013 г. - Электрон. текст. дан. (220 Мб). - Мурманск: Изд-во Мурм. гос. техн. ун-та, 2013. - 
C. 240-242. - 1 электрон. опт. диск (CD-ROM). - Систем. требования: PC не ниже класса Pentium II; $128 \mathrm{Mb}$ RAM; свободное место на HDD $130 \mathrm{Mb}$; дисковод CD-ROM 2-х и выше. - Загл. с экрана. - Электрон. текст подг. ФГБОУ ВПО «МГТУ». - № гос. регистрации 0321301202.

1090. Желудкова А.И. Структурные уровни поведения кольчатой нерпы (Pusa hispida) и гренландского тюленя (Pagophilus groenlandicus) в условиях неволи // Материалы XXXI конференции молодых ученых Мурманского морского биологического института, посвященной 135летию со дня рождения К.М. Дерюгина, «Океанография и биология арктических морей» (г. Мурманск, май 2013). - Мурманск: Изд. ММБИ КНЦ РАН, 2013. - С. 75-80.

1091. Зайцев A.A. Структура суточного поведения гренландского тюленя в условиях вольерного содержания // Материалы XXIX конференции молодых ученых Мурманского морского биологического института, посвященной 140 -летию со дня рождения Г.А. Клюге, «Морские исследования экосистем европейской Арктики» (г. Мурманск, май 2011 г.). - Мурманск: Изд. ММБИ КНЦ РАН, 2011. - С. 74-78.

1092. Зайцев A.A. Изменения суточной динамики поведения гренландского тюленя, вызванные патологическими нарушениями в организме // Материалы XXXI конференции молодых ученых Мурманского морского биологического института, посвященной 135летию со дня рождения К.М. Дерюгина, «Океанография и биология арктических морей» (г. Мурманск, май 2013). - Мурманск: Изд. ММБИ КНЦ РАН, 2013. - С. 80-85.

1093. Зайцев A.A. Структура суточного поведения гренландского тюленя // Проблемы изучения и охраны животного мира на Севере: Матер. II Всерос. конф. с междунар. участием. - Сыктывкар: Изд-во Коми НЦ УрО РАН, 2013. - С. 77-79.

1094. Зайцев А.А., Лазуренко В.В. Характер изменений в поведении гренландского тюленя при влиянии различных факторов // Арктическое морское природопользование в XXI веке - современный баланс научных традиций и инноваций (к 80-летию ММБИ КНЦ РАН): Тез. докл. Междунар. науч. конф. (г. Мурманск, 1-3 апреля 2015 г.). Апатиты: Изд-во КНЦ РАН, 2015. - С. 71-72.

1095. Зензеров В.С. Эндокринные механизмы в адаптации камчатского краба Баренцева моря к изменению среды обитания // Арктическое морское природопользование в XXI веке - современный баланс научных традиций и инноваций (к 80-летию ММБИ КНЦ РАН): Тез. докл. Междунар. науч. конф. (г. Мурманск, 1-3 апреля 2015 г.). Апатиты: Изд-во КНЦ РАН, 2015. - С. 79-80. 
1096. Зензеров В.С. Гормоны камчатского краба Баренцева моря и их роль в адаптации вселенца к новым условиям обитания // Современные проблемы экологии и природопользования: Матер. регион. науч.-практ. конф., посвященной 15-летию со дня основания кафедры биоэкологии, Мурманск, 27-28 февраля 2014 г. - Мурманск: Изд-во Мурм. гос. техн. ун-та, 2014. - С. 47-50.

1097. Зензеров В.С., Типисова Е.В. Определение уровней гормонов в гемолимфе камчатского краба Баренцева моря радиоиммунологическим методом // Глобальные климатические процессы и их влияние на экосистемы арктических и субарктических регионов: Тез. докл. Междунар. науч. конф. (г. Мурманск, 9-11 ноября 2011 г.). - Апатиты: Изд-во КНЦ РАН, 2011. - С. 75-76.

1098. Извекова Г.И., Куклина М.М. Заражение цестодами и активность пищеварительных гидролаз позвоночных хозяев // Паразитология в изменяющемся мире: Матер. V Съезда паразитол. общ-ва при РАН и Всерос. конф. с междунар. участием. - Новосибирск: Гарамонд, 2013. - С. 78.

1099. Извекова Г.И., Куклина М.М. Активность пищеварительных гидролаз при заражении цестодами позвоночных хозяев // Тр. Центра паразитологии ИПЭЭ РАН. - 2014. - С. 106-108.

1100. Изменчивость формулы периферической крови под действием регионального и промышленного факторов у жителей Республики Карелия и Мурманской области / A.A. Троиенко, A.T. Терехин, E.В. Будилова, Н.Г. Журавлева // Актуальные проблемы экологии и природопользования. Вып.13. - М.: Изд-во Рос. ун-та дружбы народов, 2011. - Ч. 1. - С. 344-347.

1101. Илющенко А.М., Зензеров В.С. Влияние экспериментального голодания на морфологию антеннальной железы и белковые фракции мышечной ткани камчатского краба Paralithodes camtschaticus Баренцева моря // Рыбное хозяйство. - 2011. - № 6. - С. 63-64.

1102. Иикулов Д.Г., Михайлюк А.Л., Пахомов М.В. Особенности цветовосприятия у серых тюленей // Вестн. Кольского науч. центра PAH. - 2013. - № 4(15). - С. 84-90.

1103. Кавиевич Н.Н. Гематологические показатели обыкновенных морских свиней при отравлении нефтепродуктами // Изв. Самар. науч. центра РАН. - 2011. - Т. 13, № 1(5). - С. 1109-1112.

1104. Кавцевич Н.Н. Морфологические и цитохимические особенности клеток крови морских млекопитающих в связи с адаптацией к среде обитания: Автореф. дис. ... докт. биол. наук (03.03.01 - физиология; 03.02.04 - зоология). - Петрозаводск, 2011. - 39 с. 
1105. Кавиевич Н.Н. Цитохимическое исследование структуры популяции лимфоцитов периферической крови афалин // Изв. Самар. науч. центра РАН. - 2011. - Т. 13, № 1(5). - С. 1113-1118.

1106. Кавцевич Н.Н. Цитохимические особенности лимфоцитов крови дельфинов афалин при содержании в неволе // Актуальные вопросы ветеринарной биологии. - 2011. - № 3(11). - С. 18-23.

1107. Кавцевич Н.Н., Березина И.А. Биотехнические характеристики морских млекопитающих, перспективных для служебного использования // Морские животные на службе человеку: Матер. науч.-практ. семинара (4 октября 2010 г., Североморск). - Ростов н/Д.: Изд-во ЮНЦ РАН, 2011. - C. 25-33.

1108. Кавцевич Н.Н., Минзюк Т.В. Возрастные особенности клеточного состава крови щенков серого тюленя // Проблемы иммунологии, патологии и охраны здоровья рыб: Расширенные матер. III Междунар. конф. (18-22 июля 2011 г., пос. Борок). - М.: Изд-во РГАУ-МСХА им. К.А. Тимирязева, 2011. - С. 121-124.

1109. Кавиевич Н.Н., Минзюк Т.В. Особенности клеточного состава крови серых тюленей (Halichoerus grypus) разного возраста // Зоол. журн. - 2011. - Т. 90, № 9. - С. 1122-1126.

1110. Кавцевич Н.Н., Ерохина И.А., Минзюк Т.В. «Физиологический перекрест» лейкоцитарной формулы и особенности системы крови тюленей // Арктическое морское природопользование в XXI веке современный баланс научных традиций и инноваций (к 80-летию ММБИ КНЦ РАН): Тез. докл. Междунар. науч. конф. (г. Мурманск, 1-3 апреля 2015 г.). - Апатиты: Изд-во КНЦ РАН, 2015. - С. 94-95.

1111. Кавиевич Н.Н., Минзюк Т.В., Ерохина И.А. Экологофизиологические параметры тюленей разного возраста // Вестн. Кольского науч. центра РАН. - 2015. - № 2(21). - С. 59-69.

1112. Кардиореспираторная функция и электрическая активность мозга кольчатой нерпы при переходе от бодрствования ко сну / Г.Г. Матишов, В.Б. Войнов, Е.В. Вербиикий, А.Л. Михайлюк // Докл. PAH. - 2012. - T. 442, № 3. - C. 413-418.

1113. Кибальников А.С., Войнов В.Б., Вербиикий Е.В. Индивидуальные особенности кардиореспираторной функции в бодрствовании и во сне у северных морских котиков, пребывающих на суше // Вестн. Южного науч. центра РАН. - 2011. - Т. 7, № 2. - С. 86-93.

1114. Кибальников А.С., Войнов В.Б., Вербицкий Е.В. Аритмия дыхания и частоты сердечных сокращений в цикле сон-бодрствование северных морских котиков (Callorhinus ursinus) на суше // Морские 
млекопитающие Голарктики 2012: Сб. науч. тр. по матер. VII Междунар. конф. (г. Суздаль, 24-28 сентября 2012 г.). - М.: РОО «Совет по морским млекопитающим», 2012. - Т. 1. - С. 290-296.

1115. Куклина М.М. Физиологические особенности взаимоотношений в системе паразит-хозяин на примере моевки и ленточных червей // Современные проблемы эволюционной морфологии животных: Матер. II Всерос. конф. с междунар. участием, посвященной 105-летию со дня рождения академика А.В. Иванова (17-19 октября 2011 г., г. СанктПетербург, Россия). - СПб.: Изд. Зоол. ин-та РАН, 2011. - С. 222-225.

1116. Куклина М.М. Особенности процессов пищеварения как возможные адаптации к колониальному образу жизни на примере толстоклювой и тонкоклювой кайр // Теоретические аспекты колониальности у птиц. - Ростов н/Д.: Изд-во ЮНЦ РАН, 2012. - С. 199-203.

1117. Куклина М.М. Показатели обмена веществ моевки при цестодной инвазии // Материалы V Всероссийской конференции с международным участием по теоретической и морской паразитологии (23-27 апреля 2012 г., Светлогорск, Калининградская обл.). Калиниград: Изд. АтлантНИРО, 2012. - С. 117-120.

1118. Куклина М.М. Влияние цестодной инвазии на биохимические показатели толстоклювой (Uria lomvia) и тонкоклювой (Uria aalge) кайр Баренцева моря // Физиологические, биохимические и молекулярногенетические механизмы адаптаций гидробионтов: Матер. Всерос. конф. с междунар. участием (22-28 сент. 2012 г., пос. Борок). - Борок: Изд. Ин-та биол. внутр. вод им. И.Д. Папанина, 2012. - С. 214-218.

1119. Куклина М.М. Сопряженность процессов пищеварения у глупыша Fulmarus glacialis и паразитирующей в нем цестоды Tetrabothrius minor (Cestoda: Tetrabothriidae) // Докл. РАН. - 2012. T. 446, № 3. - C. 350-353.

1120. Куклина М.M. Трофические отношения в системе паразитхозяин (на примере атлантического глупыша Fulmarus glacialis и цестоды Tetrabothrius minor (Cestoda: Tetrabothriidae) // Современные проблемы общей паразитологии: Матер. Междунар. конф. (30 октября1 ноября 2012 г., г. Москва). - М.: Изд. Центра паразитологии ИПЭЭ PAH, 2012. - C. 182-186.

1121. Куклина М.М. Физиологические особенности взаимоотношений в системе паразит-хозяин на примере моевки и ленточных червей // Проблемы цестодологии. Вып. IV. - СПб.: Элмор, 2012. - C. 123-132.

1122. Куклина M.M. Влияние паразитирования цестоды Alcataenia armillaris (Cestoda: Dilepididae) на биохимические показатели толстоклювой и тонкоклювой кайр Баренцева моря // Рос. паразитол. журн. - 2013. № 2. - C. 58-63. 
1123. Куклина М.M. Распределение Tetrabothrius erostris (Cestoda: Tetrabothriidae) в кишечнике серебристых чаек в зависимости от активности ферментов // Тр. Центра паразитологии ИПЭЭ РАН. -2014. - С. 152-154.

1124. Куклина М.М. Физиологическое состояние морского песочника при заражении трематодами их разных систематических групп // Современные проблемы экологии и природопользования: Матер. регион. науч.-практ. конф., посвященной 15-летию со дня основания кафедры биоэкологии, Мурманск, 27-28 февраля 2014 г. - Мурманск: Изд-во Мурм. гос. техн. ун-та, 2014. С. 227-230.

1125. Куклина М.М. Биохимические показатели плазмы крови серебристой чайки при инвазии Tetrabothrius erostris (Cestoda: Tetrabothriidae) // Рос. паразитол. журн. - 2015. - Вып. 4 . - С. 79-84.

1126. Куклина М.М. Взаимоотношения в системе атлантический глупыш Fulmarus glacialis-цестода Tetrabothrius minor (Cestoda: Tetrabothriidae): физиологические аспекты // Паразитология. - 2015. T. 49, № 6. - С. 433-443.

1127. Куклина М.М. Физиология питания Tetrabothrius erostris (Cestoda: Tetrabothriidae) из кишечника моевки и серебристой чайки // Арктическое морское природопользование в XXI веке - современный баланс научных традиций и инноваций (к 80-летию ММБИ КНЦ РАН): Тез. докл. Междунар. науч. конф. (г. Мурманск, 1-3 апреля 2015 г.). Апатиты: Изд-во КНЦ РАН, 2015. - С. 125-126.

1128. Куклина М.М., Куклин В.В. Биохимические аспекты взаимоотношений в системе паразит-хозяин на примере моевки и ленточных червей из разных систематических групп // Докл. РАН. - 2011. - Т. 438, № 1. - C. 129-133.

1129. Куклина М.М., Куклин В.В. Биохимические и гематологические показатели моевки Rissa tridactyla (Linnaeus, 1758) при инвазии цестодами Alcataenia larina (Krabbe, 1869) (Cestoda: Dilepididae) // Рос. паразитол. журн. - 2011. - № 3. - С. 62-67.

1130. Куклина М.М., Куклин В.В. Особенности гидролиза белков на пищеварительно-транспортных поверхностях кишечника моевки Rissa tridactyla и паразитирующей в нем Acataenia larina (Cestoda: Dilepididae) // Изв. РАН. Сер. Биол. - 2011. - № 5. - С. 550-556.

1131. Куклина М.М., Куклин В.В. Активность пищеварительных ферментов толстоклювой (Uria lomvia) и тонкоклювой (U. aalge) кайр при инвазии ленточными червями // Журн. эволюцинной биохимии и физиологии. - 2012. - Т. 48, № 3. - С. 225-231.

1132. Куклина М.М., Куклин В.В. Особенности обмена веществ птенцов моевки Rissa trydactyla (Linnaeus, 1758) при инвазии цестодами // Рос. паразитол. журн. - 2013. - № 1. - C. 49-53. 
1133. Куклина М.М., Куклин В.В. Показатели углеводного обмена толстоклювой кайры (Uria lomvia) при инвазии Alcataenia armillaris (Cestoda: Dilepididae) // Изв. РАН. Сер. Биол. - 2013. - № 4. - С. 431-436.

1134. Куклина М.М., Куклин В.В. Экспериментальное исследование особенностей физиологии и питания ленточных червей Tetrabothrius minor (Cestoda: Tetrabothriidae) // Вестн. Кольского науч. центра РАН. 2015. - № 2(21). - C. 49-52.

1135. Лазуренко В.В. Роль типологических индивидуальных особенностей тюленя в биотехнической системе // Материалы XXXI конференции молодых ученых Мурманского морского биологического института, посвященной 135-летию со дня рождения К.М. Дерюгина, «Океанография и биология арктических морей» (г. Мурманск, май 2013). - Мурманск: Изд. ММБИ КНЦ РАН, 2013. - С. 114-116.

1136. Лазуренко В.В., Зайцев А.А. Выявление реакции тюленя на отсутствие ранее подкрепляемого стимула // Материалы XXX юбилейной конференции молодых ученых Мурманского морского биологического института, посвященной 150-летию со дня рождения H.M. Книповича, «Проблемы океанографии, биологии и освоения биоресурсов морей российской Арктики» (г. Мурманск, май 2012). Мурманск: Изд. ММБИ КНЦ РАН, 2012. - С. 106-108.

1137. Ластоногие: аритмия циклических процессов в поведении и физиологии / В.Б. Войнов, А.А. Зайцев, А.Л. Михайлюк, М.В. Пахомов // Морские экосистемы и сообщества в условиях современных климатических изменений. - СПб.: Реноме, 2014. - С. 312-325.

1138. Литвинов Ю.В. Выработка условных рефлексов у серых тюленей с использованием обонятельных раздражителей // Материалы XXIX конференции молодых ученых Мурманского морского биологического института, посвященной 140 -летию со дня рождения Г.А. Клюге, «Морские исследования экосистем европейской Арктики» (г. Мурманск, май 2011 г.). - Мурманск: Изд. ММБИ КНЦ РАН, 2011. - С. 121-124.

1139. Литвинов Ю.В. Выработка у серых тюленей условных рефлексов на обонятельные раздражители различными методами [Электронный ресурс] // Наука и образование - 2012: Матер. Междунар. науч.-техн. конф., Мурманск, 2-6 апреля 2012 г. - Электрон. текст. дан. (30 Мб). - Мурманск: Изд-во Мурм. гос. техн. ун-та, 2012. С. 322-325. 1 электрон. опт. диск (CD-ROM). - Систем. требования: PC не ниже класса Pentium II; 128 Mb RAM; свободное место на HDD 130 Мб; дисковод CD-ROM 2-х и выше. - Загл. с экрана. - Электрон. текст подг. ФГБОУ ВПО «МГТУ». - № гос. регистрации 0321201101.

1140. Литвинов Ю.В. Обонятельная чувствительность серых тюленей к сульфиду этана // Материалы XXX юбилейной конференции 
молодых ученых Мурманского морского биологического института, посвященной 150-летию со дня рождения Н.М. Книповича, «Проблемы океанографии, биологии и освоения биоресурсов морей российской Арктики» (г. Мурманск, май 2012). - Мурманск: Изд. ММБИ КНЦ PAH, 2012. - C. 108-111.

1141. Литвинов Ю.В. Возможность выработки условных рефлексов на обанятельные раздражители у серых тюленей // Материалы Всероссийской конференции молодых ученых и специалистов с международным участием, посвященной 90-летию со дня постройки первого научно-исследовательского судна ПИНРО «Персей». Мурманск: Изд-во ПИНРО, 2012. - С. 161-166.

1142. Литвинов Ю.В. Использование сульфида этана как условного раздражителя на обонятельные реакции у серых тюленей // 2013 год - год охраны окружающей среды в России: Тез. докл. конф. молодых ученых (Мурманск, 12-13 февраля 2013 г.). - Мурманск: Изд-во Мурм. гос. техн. ун-та, 2013. - С. 42-89.

1143. Литвинов Ю.В. Диметилсульфид как вероятное «сигнальное» вещество при поиске пищи у гренландских тюленей // Материалы XXXI конференции молодых ученых Мурманского морского биологического института, посвященной 135-летию со дня рождения К.М. Дерюгина, «Океанография и биология арктических морей» (г. Мурманск, май 2013). - Мурманск: Изд. ММБИ КНЦ РАН, 2013. С. 117-122.

1144. Литвинов Ю.В. Способность серых тюленей к дифференциации сульфида этана по обонятельным признакам // Проблемы изучения и охраны животного мира на Севере: Матер. II Всерос. конф. с междунар. участием. - Сыктывкар: Изд-во Коми НЦ УрО РАН, 2013. - С. 130-132.

1145. Литвинов Ю.В. Способность гренландских тюленей к выбору диметилсульфида по обонятельному признаку // Эколого-эволюционные исследования морских организмов и экосистем: Матер. XIV Междунар. науч. конф. студентов и аспирантов «Проблемы Арктического региона» (г. Мурманск, май 2014 г.). Т. І. Форум молодых ученых, посвященный 110-летию со дня рождения Ю.И. Полянского (XXXII конференция молодых ученых ММБИ). - Мурманск: Изд. ММБИ КНЦ РАН, 2014. C. $82-85$.

1146. Литвинов Ю.В. Обонятельная чувствительность гренландских тюленей к диметилсульфиду // Арктическое морское природопользование в XXI веке - современный баланс научных традиций и инноваций (к 80-летию ММБИ КНЦ РАН): Тез. докл. Междунар. науч. конф. (г. Мурманск, 1-3 апреля 2015 г.). - Апатиты: Изд-во КНЦ РАН, 2015. C. $136-138$. 
1147. Микросателлитная изменчивость атлантического моржа (Odobenus rosmarus rosmarus) с лежбищ архипелага Земля Франца-Иосифа и северной оконечности Новой Земли / М.В. Шитова, М.В. Гаврило, И.А. Мизин, Ю.В. Краснов, И.И. Чупин // Морские млекопитающие Голарктики: Сб. науч. тр. VIII Междунар. конф. (Санкт-Петербург, 2227 сентября 2014). - М.: РОО «Совет по морским млекопитающим», 2015. - T. 2. - C. 319-326.

1148. Минзюк T.B. Возрастные изменения бактерицидной активности зернистых лейкоцитов серых тюленей // Вестн. Южного науч. центра PAН. - 2011. - Т. 7, № 4. - С. 70-73.

1149. Минзюк T.В. Содержание катионных бактерицидных белков в гранулоцитах серых тюленей // Материалы XXIX конференции молодых ученых Мурманского морского биологического института, посвященной 140 -летию со дня рождения Г.А. Клюге, «Морские исследования экосистем европейской Арктики» (г. Мурманск, май 2011 г.). Мурманск: Изд. ММБИ КНЦ РАН, 2011. - С. 147-150.

1150. Минзюк T.B. Некоторые показатели естественной резистентности тюленей в постанатальном онтогенезе // Изучение и освоение морских и наземных экосистем в условиях арктического и аридного климата: Матер. Междунар. науч. конф. (6-11 июня 2011 г., Ростов-на-Дону). - Ростов н/Д.: Изд-во ЮНЦ РАН, 2011. - С. 295-297.

1151. Минзюк T.B. Морфофункциональные особенности лейкоцитов тюленей разного возраста: Автореф. дис. ... канд. биол. наук (03.03.01 физиология). - Петрозаводск, 2012. - 23 с.

1152. Минзюк T.B. Морфометрические параметры районов организаторов ядрышка в лимфоцитах тюленей разного возраста // Материалы XXX юбилейной конференции молодых ученых Мурманского морского биологического института, посвященной 150 -летию со дня рождения Н.М. Книповича, «Проблемы океанографии, биологии и освоения биоресурсов морей российской Арктики» (г. Мурманск, май 2012). - Мурманск: Изд. ММБИ КНЦ РАН, 2012. - С. 129-134.

1153. Минзюк T.B. Цитохимическая оценка функционального состояния лейкоцитов крови афалин разного возраста // Материалы XXXI конференции молодых ученых Мурманского морского биологического института, посвященной 135-летию со дня рождения К.М. Дерюгина, «Океанография и биология арктических морей» (г. Мурманск, май 2013). - Мурманск: Изд. ММБИ КНЦ РАН, 2013. - С. 139-143.

1154. Минзюк T.B. Клеточный состав крови морского зайца // Эколого-эволюционные исследования морских организмов и экосистем: Матер. XIV Междунар. науч. конф. студентов и аспирантов «Проблемы Арктического региона» (г. Мурманск, май 2014 г.). Т. І. Форум молодых 
ученых, посвященный 110-летию со дня рождения Ю.И. Полянского (XXXII конференция молодых ученых ММБИ). - Мурманск: Изд. ММБИ КНЦ РАН, 2014. - С. 116-122.

1155. Минзюк Т.В. Морфологическая и цитохимическая характеристика лейкоцитов крови щенков серого тюленя // Арктическое морское природопользование в XXI веке - современный баланс научных традиций и инноваций (к 80-летию ММБИ КНЦ РАН): Тез. докл. Междунар. науч. конф. (г. Мурманск, 1-3 апреля 2015 г.). - Апатиты: Изд-во КНЦ РАН, 2015. - С. 163-165.

1156. Минзюк Т.В., Кавцевич Н.Н. Бактерицидный катионный белок в клетках крови морских млекопитающих // Физиологические, биохимические и молекулярно-генетические механизмы адаптаций гидробионтов: Матер. Всерос. конф. с междунар. участием (22-28 сент. 2012 г., пос. Борок). - Борок: Изд. Ин-та биол. внутр. вод им. И.Д. Папанина, 2012. - С. 263-266.

1157. Минзюк Т.В., Кавцевич Н.Н. Миелопероксидаза и бактерицидные катионные белки в лейкоцитах серого тюленя (Halichoerus grypus Fabricius, 1791) // Морские млекопитающие Голарктики 2012: Сб. науч. тр. по матер. VII Междунар. конф. (г. Суздаль, 24-28 сентября 2012 г.). М.: РОО «Совет по морским млекопитающим», 2012. - С. 95-99.

1158. Минзюк T.В., Кавцевич Н.Н. Содержание бактерицидного катионного белка в лейкоцитах дельфинов-афалин, гренландских и серых тюленей // Животные: экология, биология и охрана: Матер. Bcepoc. науч. конф. с междунар. участием (г. Саранск, 29 ноября 2012 г.). - Саранск: Изд-во Мордов. гос. ун-та, 2012. - С. 251-254.

1159. Минзюк T.В., Кавцевич Н.Н. Бактерицидный катионный белок в лейкоцитах морских млекопитающих // Вестн. Мурм. гос. техн. ун-та. - 2013. - Т. 16, № 3. - С. 506-511.

1160. Минзюк Т.В., Кавцевич Н.Н. Морфофункциональные особенности лейкоцитов тюленей разного возраста // Современные проблемы анатомии, гистологии и эмбриологии животных: Матер. V Bcepoc. науч. интернет-конф. с междунар. участием (22-23 апреля 2014 г., г. Казань). - Казань: ИП Синяев Д.Н., 2014. - С. 123-130.

1161. Минзюк T.B., Кавцевич Н.Н. К оценке функционального состояния лейкоцитов крови дельфинов афалин // Проблемы патологии, иммунологии и охраны здоровья рыб и других гидробионтов: Расширенные матер. IV Междунар. конф., Борок, 24-27 сентября 2015 г. - Ярославль: Филигрань, 2015. - С. 73-80.

1162. Минзюк Т.В., Кавиевич Н.Н. Показатели лейкоцитарной формулы крови серых тюленей в постнатальном онтогенезе // Современные эколого-биологические и химические исследования, 140 
техника и технология производств: Матер. Междунар. науч.-практ. конф., Мурманск, 7 апреля 2015 г.: В 2-х ч. - Мурманск: Изд-во Мурм. гос. техн. ун-та, 2015. - Ч. 1. - С. 147-151.

1163. Минзюк Т.В., Кавцевич Н.Н., Светочев В.Н. Новые данные о морфофункциональных особенностях лейкоцитов морских зайцев (Erignathus barbatus) // Морские млекопитающие Голарктики 2014: Тез. докл. VIII Междунар. конф. (г. Санкт-Петербург, 24-27 сентября 2014 г.). - СПб.: РОО «Совет по морским млекопитающим», 2014. - С. 47.

1164. Минзюк Т.В., Кавцевич Н.Н., Светочев В.Н. Новые данные о морфофункциональных особенностях лейкоцитов морских зайцев (Erignathus barbatus) // Морские млекопитающие Голарктики: Сб. науч. тр. VIII Междунар. конф. (Санкт-Петербург, 22-27 сентября 2014 г.). М.: РОО «Совет по морским млекопитающим», 2015. - Т. 2. - С. 11-16.

1165. Минзюк Т.В., Кавцевич Н.Н., Светочев В.Н. Новые данные о клеточном составе крови морского зайца // Докл. РАН. - 2015. Т. 462, № 6. - С. 727-729.

1166. Михайлюк А.Л. Влияние постоянного и импульсного шума на параметры поведения кольчатой нерпы // Биоресурсы и аквакультура: Тез. докл. Школы молодых ученых по морской биологии (Мурманск, 28-29 февраля 2012 г.). - Мурманск: Изд-во Мурм. гос. техн. ун-та, 2012. - C. 32-33.

1167. Михайлюк А.Л. Техногенное шумовое загрязнение Баренцева моря и его влияние на биологию кольчатой нерпы: Автореф. дис. ... канд. биол. наук (25.00.28 - океанология). - Мурманск, 2012. - 23 с.

1168. Михайлюк А.Л. Техногенное шумовое загрязнение Баренцева моря и его влияние на биологию кольчатой нерпы // Арктическое морское природопользование в XXI веке - современный баланс научных традиций и инноваций (к 80-летию ММБИ КНЦ РАН): Тез. докл. Междунар. науч. конф. (г. Мурманск, 1-3 апреля 2015 г.). Апатиты: Изд-во КНЦ РАН, 2015. - С. 166-167.

1169. Михайлюк А.Л., Войнов В.Б. Перестройки поведения и параметров высшей нервной деятельности кольчатой нерпы в ответ на шумовое акустическое воздействие // Морские млекопитаюшие Голарктики 2012: Сб. науч. тр. по матер. VII Междунар. конф. (г. Суздаль, 24-28 сентября 2012 г.). - М.: РОО «Совет по морским млекопитающим», 2012. - T. 2. C. $460-464$.

1170. Михайлюк А.Л., Пахомов М.В., Войнов В.Б. Исследование механизма цветовосприятия серых тюленей // Морские млекопитающие Голарктики 2014: Тез. докл. VIII Междунар. конф. (г. Санкт-Петербург, 24-27 сентября 2014 г.). - СПб.: РОО «Совет по морским млекопитающим», 2014. C. 46. 
1171. Морфофункциональная характеристика взаимосвязей между маткой и зародышами у цестод из различных таксонов / Ж.В. Корнева, С.А. Корниенко, Н.М. Пронин, В.В. Куклин // Паразитология в изменяющемся мире: Матер. V Съезда паразитол. общ-ва при РАН и Всерос. конф. с междунар. участием. Новосибирск: Гарамонд, 2013. - С. 91.

1172. Муравейко А.В., Емелина А.В. Влияние вариаций магнитного поля Земли на морских беспозвоночных животных // Современные экологобиологические и химические исследования, техника и технология производств: Матер. Междунар. науч.-практ. конф., Мурманск, 7 апреля 2015 г.: В 2-х ч. - Мурманск: Изд-во Мурм. гос. техн. ун-та, 2015. Ч. 1. - C. 238-242.

1173. Муравейко В.М., Гладких А.С., Емелина А.В. Влияние питания на сердечную деятельность гренландского тюленя // Морские животные на службе человеку: Матер. науч.-практ. семинара (4 октября 2010 г., Североморск). - Ростов н/Д.: Изд-во ЮНЦ РАН, 2011. - C. 71-75.

1174. Муравейко В.М., Степанюк И.А. Зензеров В.С. Реакция краба Paralithodes camtschaticus (Tilesius, 1815) на геомагнитную бурю // Докл. РАН. - 2013. - Т. 448, № 6. - С. 729-731.

1175. Ненашева-Желудкова А.И. Структурные уровни поведения у кольчатой нерпы (Pusa hispida) и гренландского тюленя (Pagophilus groenlandicus) в условиях неволи // Актуальные исследования гуманитарных, естественных, точных и общественных наук: Матер. III Междунар. науч.-практ. конф. (г. Новосибирск, 25 ноября 2013 г.). Новосибирск: ООО «ЦСРНИ», 2013. С. 81-93.

1176. Ненашева-Желудкова А.И. Территориальное поведение кольчатой нерпы (Pusa hispida) и гренландского тюленя (Pagophilus groenlandicus), содержащихся в условиях неволи // Эколого-эволюционные исследования морских организмов и экосистем: Матер. XIV Междунар. науч. конф. студентов и аспирантов «Проблемы Арктического региона» (г. Мурманск, май 2014 г.). Т. І. Форум молодых ученых, посвященный 110-летию со дня рождения Ю.И. Полянского (XXXII конференция молодых ученых ММБИ). - Мурманск: Изд. ММБИ КНЦ РАН, 2014. - С. 122-126.

1177. Ненашева-Желудкова А.И. Стереотипная траектория движения как критерий оценки влияния внешних и внутренних факторов на поведение кольчатой нерпы Pusa hispida // Арктическое морское природопользование в XXI веке - современный баланс научных традиций и инноваций (к 80-летию ММБИ КНЦ РАН): Тез. докл. Междунар. науч. конф. (г. Мурманск, 1-3 апреля 2015 г.). - Апатиты: Изд-во КНЦ РАН, 2015. - С. 174-176. 
1178. Ненашева-Желудкова А.И., Кавцевич Н.Н. Территориальное поведение кольчатой нерпы (Pusa hispida) и гренландского тюленя (Pagophilus groenlandicus) в неволе// Морские млекопитающие Голарктики 2014: Тез. докл. VIII Междунар. конф. (г. СанктПетербург, 24-27 сентября 2014 г.). - СПб.: РОО «Совет по морским млекопитающим», 2014. - С. 48.

1179. О созревании кардиореспираторной функции у настоящих тюленей (Phocidae) / Е.В. Вербицкий, В.Б. Войнов, А.А. Кондаков, Е.П. Олейников // Морские млекопитающие Голарктики: Сб. науч. тр. VIII Междунар. конф. (Санкт-Петербург, 22-27 сентября 2014 г.). - М.: POО «Совет по морским млекопитающим», 2015. - Т. 1. - С. 125-132.

1180. Пахомов М.В. Исследование возможностей дифференцировки объектов по цветовому признаку представителями трех видов настоящих тюленей // Материалы XXIX конференции молодых ученых Мурманского морского биологического института, посвященной 140летию со дня рождения Г.А. Клюге, «Морские исследования экосистем европейской Арктики» (г. Мурманск, май 2011 г.). - Мурманск: Изд. ММБИ КНЦ РАН, 2011. - С. 169-174.

1181. Пахомов М.В. Исследование особенности арктических тюленей к дифференцировке объекта по цвету // Материалы XXX юбилейной конференции молодых ученых Мурманского морского биологического института, посвященной 150-летию со дня рождения Н.М. Книповича, «Проблемы океанографии, биологии и освоения биоресурсов морей российской Арктики» (г. Мурманск, май 2012). Мурманск: Изд. ММБИ КНЦ РАН, 2012. - С. 140-145.

1182. Пахомов М.В. Исследование способности дифференцировать объекты по признаку цветности у представителей трех видов настоящих тюленей // Морские млекопитающие Голарктики 2012: Сб. науч. тр. по матер. VII Междунар. конф. (г. Суздаль, 24-28 сентября 2012 г.). - М.: РОО «Совет по морским млекопитающим», 2012. - Т. 1. - С. 167-171.

1183. Пахомов М.В. Дифференцировка объектов по признаку цветности в воздушной и водных средах представителями трех видов настоящих тюленей // Материалы Всероссийской конференции молодых ученых и специалистов с международным участием, посвященной 90-летию со дня постройки первого научно-исследовательского судна ПИНРО «Персей». - Мурманск: Изд-во ПИНРО, 2012. - С. 210-214.

1184. Пахомов М.В. Адаптация цветового зрения арктических ластоногих к среде обитания // Материалы XXXI конференции молодых ученых Мурманского морского биологического института, посвященной 135-летию со дня рождения К.М. Дерюгина, «Океанография и биология арктических морей» (г. Мурманск, май 2013). - Мурманск: Изд. ММБИ КНЦ РАН, 2013. - С. 163-166. 
1185. Пахомов М.B. Влияние освещенности на цветовосприятие арктических тюленей // Проблемы изучения и охраны животного мира на Севере: Матер. II Всерос. конф. с междунар. участием. - Сыктывкар: Изд-во Коми НЦ УрО РАН, 2013. - С. 162-165.

1186. Пахомов М.В. Видовые особенности зрительной системы арктических ластоногих // Современные проблемы экологии и природопользования: Матер. регион. науч.-практ. конф., посвященной 15-летию со дня основания кафедры биоэкологии, Мурманск, 27-28 февраля 2014 г. - Мурманск: Изд-во Мурм. гос. техн. ун-та, 2014. - С. 27-32.

1187. Пахомов М.B. Особенности цветовосприятия гренландских тюленей беломорской популяции // Эколого-эволюционные исследования морских организмов и экосистем: Матер. XIV Междунар. науч. конф. студентов и аспирантов «Проблемы Арктического региона» (г. Мурманск, май 2014 г.). Т. І. Форум молодых ученых, посвященный 110-летию со дня рождения Ю.И. Полянского (XXXII конференция молодых ученых ММБИ). - Мурманск: Изд. ММБИ КНЦ РАН, 2014. - С. 141-144.

1188. Пахомов М.В. К вопросу об использовании цвета предмета как условного раздражителя при работе с арктическими тюленями // Арктическое морское природопользование в XXI веке - современный баланс научных традиций и инноваций (к 80-летию ММБИ КНЦ РАН): Тез. докл. Междунар. науч. конф. (г. Мурманск, 1-3 апреля 2015 г.). Апатиты: Изд-во КНЦ РАН, 2015. - С. 191-192.

1189. Пахомов М.B. Роль цветового зрения в экологии арктических тюленей // Современные эколого-биологические и химические исследования, техника и технология производств: Матер. Междунар. науч.-практ. конф., Мурманск, 7 апреля 2015 г.: В 2-х ч. - Мурманск: Изд-во Мурм. гос. техн. ун-та, 2015. - Ч. 1. - С. 152-157.

1190. Пахомов М.В. Результаты исследования цветового зрения настоящих тюленей Баренцева моря // Pontus Euxinus 2015: Тез. IX Всерос. науч.-практ. конф. молодых ученых (с междунар. участием) по проблемам водных экосистем, посвященной 100-летию со дня рождения д.б.н., проф., чл.-корр. АН УССР В.Н. Грёзе (17-20 ноября 2015 г.). - Севастополь: DigitPrint, 2015. - С. 116-118.

1191. Пахомов М.В., Михайлюк А.Л., Войнов В.Б. Исследование механизма цветовосприятия серых тюленей // Морские млекопитающие Голарктики: Сб. науч. тр. VIII Междунар. конф. (Санкт-Петербург, 2227 сентября 2014 г.). - М.: РОО «Совет по морским млекопитающим», 2015. - T. 2. - C. 87-93.

1192. Поливиева Е.И., Гудимов А.В. Первый опыт исследования поведенческих реакций двустворчатых моллюсков мидий в постоянных условиях [Электронный ресурс] // Охрана окружающей среды и здоровья 
человека в Российской Федерации и странах Евросоюза: Матер. Междунар. науч.-практ. конф., Мурманск, 31 окт. 2014 г. - Электрон. текст. дан. (5.15 Мб). - Мурманск: Изд-во Мурм. гос. техн. ун-та, 2014. - С. 128133. - 1 электрон. опт. диск (CD-ROM). - Систем. требования: РC не ниже класcа Pentium II; 128 Mb RAM; Windows 9x-Windows 8; свободное место на HDD 131 Мб; дисковов CD-ROM 2-х и выше. Загл. с экрана. - Электрон. текст подг. ФГБОУ ВПО «МГТУ».

1193. Реактивность ЭКГ-параметров водолазов разной квалификации при выполнении модельных нагрузок под водой / Г.Г. Матишов, В.Б. Войнов, А.Л. Михайлюк, Ю.С. Полищук // Журн. фундамент. медицины и биологии. - 2015. - № 2. - С. 19-23.

1194. Салмова Н.А., Журавлева Н.Г., Оттесен О. Современные представления о функциях вилочковой железы [Электронный ресурс] // Наука и образование - 2013: Матер. Междунар. науч.-техн. конф., Мурманск, 4-11 марта 2013 г. - Электрон. текст. дан. (220 Мб). Мурманск: Изд-во Мурм. гос. техн. ун-та, 2013. - С. 1037-1041. 1 электрон. опт. диск (CD-ROM). - Систем. требования: PC не ниже класса Pentium II; $128 \mathrm{Mb}$ RAM; свободное место на HDD $130 \mathrm{Mb}$; дисковод CD-ROM 2-х и выше. - Загл. с экрана. - Электрон. текст подг. ФГБОУ ВПО «МГТУ». - № гос. регистрации 0321301202.

1195. Светочева О.Н., Светочев В.Н. Энергетические потребности детенышей гренландского тюленя беломорской популяции (Phoca groenlandica Erxleben, 1777) на разных стадиях развития // Морские млекопитающие Голарктики: Сб. науч. тр. VIII Междунар. конф. (СанктПетербург, 22-27 сентября 2014). - М.: РОО «Совет по морским млекопитающим», 2015. - Т. 2. - С. 147-153.

1196. Сенсорные возможности арктических тюленей в морских биотехнических системах / В.Б. Войнов, А.А. Зайцев, Ю.В. Литвинов, А.Л. Михайлюк, М.В. Пахомов // Вестн. Южного науч. центра РАН. 2013. - Т. 9, № 4. - С. 87-95.

1197. Троценко А.А., Журавлева Н.Г., Будилова Е.В. Изучение влияния промышленного пресса на формулу крови жителей Республики Карелия и Мурманской области // Север в XXI веке: среда обитания, общество, освоение: Матер. Междунар. науч.-практ. конф., 1-4 декабря 2014 г. - Мурманск: Изд. Арктич. центр науч. исслед. и экспертиз, 2014. - С. 123-134.

1198. Физиология феномена апноэ во сне: от человека к морским млекопитающим / А.С. Кибальников, Е.В. Вербиикий, В.Б. Войнов, А.Л. Михайлюк // Валеология. - 2011. - № 4. - С. 102-108.

1199. Яковлев А.П. О перспективах исследования когнитивного поведения настоящих тюленей в условиях биотехнического акваполигона // 
Арктическое морское природопользование в XXI веке - современный баланс научных традиций и инноваций (к 80-летию ММБИ КНЦ РАН): Тез. докл. Междунар. науч. конф. (г. Мурманск, 1-3 апреля 2015 г.). Апатиты: Изд-во КНЦ РАН, 2015. - С. 261-262.

1200. About cardiorespiratory function maturation in the seals (Phocidae) / E.V. Verbitsky, V.B. Voinov, A.A. Kondakov, E.P. Oleynikov // Marine Mammals of the Holarctic: Abstr. book VIII Intern. Conf. (September 2014, St. Petersburg). - SPb., 2014. - P. 127.

1201. Kuklina M.M., Kuklin V.V. Carbohydrate metabolism parameters in the thick-billed murre (Uria lomvia) infested with Alcataenia armillaris (Cestoda: Dilepididae) // Biol. Bull. - 2013. - Vol. 40, iss. 4. - P. 372-376. URL: http://link.springer.com/article/10.1134/S1062359013040092

1202. Matishov G.G., Voinov V.B., Mikhaylyuk A.L. Arrhythmic phenomena in organization of cyclic processes in organisms of Pinnipedia and their behaviour // Advances Zool. Res. - NY: Nova Sci. Publ. Inc. USA, 2012. - Vol. 1. - P. 155-171. - URL: https://www.novapublishers.com/

1203. Mikhaylyuk A.L., Pachomov M.V., Voinov V.B. Investigation of the color sensitivity mechanism of gray seals // Marine Mammals of the Holarctic: Abstr. book VIII Intern. Conf. (September 2014, St. Petersburg). SPb., 2014. - P. 110.

1204. Minzyuk T.V., Kavtsevich N.N., Svetochev V.N. New data on the blood cell composition of bearded seal // Doklady Biol. Sci. - 2015. Vol. 462, № 1. - P. 152-154.

1205. Nenasheva-Zheludkova A.I., Kavtsevich N.N. Territorial behaviour of ringed seal (Pusa hispida) and harp seal (Pagophilus groenlandicus) in captivity // Marine Mammals of the Holarctic: Abstr. book VIII Intern. Conf. (September 2014, St. Petersburg). - SPb., 2014. - P. 111.

1206. Yerokhina I.A. To a question on indicators of a marine mammals physiological state sorption capacity of erythrocytes // Marine Mammals of the Holarctic: Abstr. book VIII Intern. Conf. (September 2014, St. Petersburg). - SPb., 2014. - P. 129.

\section{гистология и цитология}

1207. Журавлева Н.Г. Морфологическое строение пищеварительного тракта личинок атлантического палтуса Hippoglossus hippoglossus // Арктическое морское природопользование в XXI веке - современный баланс научных традиций и инноваций (к 80-летию ММБИ КНЦ РАН): Тез. докл. Междунар. науч. конф. (г. Мурманск, 1-3 апреля 2015 г.). Апатиты: Изд-во КНЦ РАН, 2015. - С. 70-71. 
1208. Илющенко А.М., Зензеров В.С. Морфология антенальной железы камчатского краба Paralithodes camtschaticus Баренцева моря при экспериментальном голодании и изменении солености // Вестн. Южного науч. центра РАН. - 2011. - Т. 7, № 1. - С. 76-79.

1209. Кабанова Н.А., Журавлева Н.Г. Морфологические и гистохимические особенности тимуса личинок атлантического палтуса Hippoglossus hippoglosus L. // Проблемы и перспективы развития рыбохозяйственного комплекса на современном этапе: Тез. докл. I Междунар. науч. конф. молодых ученых (г. Мурманск, 22-24 октября 2014 г.). - Мурманск: Изд-во ПИНРО, 2014. - С. 71-75.

1210. Кабанова Н.А., Журавлева Н.Г. Некоторые особенности морфофизиологических изменений тимуса семги в онтогенезе // Современные эколого-биологические и химические исследования, техника и технология производств: Матер. Междунар. науч.-практ. конф., Мурманск, 7 апреля 2015 г.: В 2-х ч. - Мурманск: Изд-во Мурм. гос. техн. ун-та, 2015. - Ч. 1. - С. 214-217.

1211. Кабанова Н.А., Журавлева Н.Г. Реактивность тимуса сеголеток семги при его непосредственном повреждении // Современные экологобиологические и химические исследования, техника и технология производств: Матер. Междунар. науч.-практ. конф., Мурманск, 7 апреля 2015 г.: В 2-х ч. - Мурманск: Изд-во Мурм. гос. техн. ун-та, 2015. Ч. 1. - C. 218-221.

1212. Новообразования в плавательном пузыре молоди трески / Н.Г. Журавлева, Г.Г. Матишов, О. Оттесен, Т.М. Ларина // Докл. PAH. - 2011. - T. 440, № 1. - C. 129-131.

1213. Салмова Н.А., Журавлева Н.Г. Гистологическое строение поджелудочной железы молоди трески (Gadus morhua L.) [Электронный ресурс] // Наука и образование - 2011: Матер. Междунар. науч.-техн. конф. - Электрон. текст. дан. (30 Мб). - Мурманск: Изд-во Мурм. гос. техн. ун-та, 2011. - C. 657-663. - 1 электрон. опт. диск (CD-ROM). Систем. требования: PC не ниже класса Pentium II; 128 Mb RAM; свободное место на HDD 30 Мб; дисковод CD-ROM 2-х и выше; Загл. с экрана. - Электрон. текст подг. ФГБОУ ВПО «МГТУ». - № гос. регистрации 0321100504.

1214. Салмова Н.А., Журавлева Н.Г. Строение печени молоди трески (Gadus morhua L.) [Электронный ресурс] // Наука и образование 2011: Матер. Междунар. науч.-техн. конф. - Электрон. текст. дан. (30 Мб). - Мурманск: Изд-во Мурм. гос. техн. ун-та, 2011. - С. 651-657. 1 электрон. опт. диск (CD-ROM). - Систем. требования: PC не ниже класса Pentium II; $128 \mathrm{Mb}$ RAM; свободное место на HDD 30 Мб; дисковод CD-ROM 2-х и выше; - Загл. с экрана. - Электрон. текст подг. ФГБОУ ВПО «МГТУ». - № гос. регистрации 0321100504. 
1215. Салмова Н.А., Журавлева Н.Г. Строение печени и поджелудочной железы молоди атлантической трески [Электронный ресурс] // Наука и образование - 2012: Матер. Междунар. науч.-техн. конф., Мурманск, 2-6 апреля 2012 г. - Электрон. текст. дан. (30 Мб). Мурманск: Изд-во Мурм. гос. техн. ун-та, 2012. - С. 413-416. 1 электрон. опт. диск (CD-ROM). - Систем. требования: PC не ниже класса Pentium II; $128 \mathrm{Mb}$ RAM; свободное место на HDD 130 Мб; дисковод CD-ROM 2-х и выше. - Загл. с экрана. - Электрон. текст подг. ФГБОУ ВПО «МГТУ». - № гос. регистрации 0321201101.

1216. Троченко А.А., Журавлева Н.Г. Молекулярно-генетические аспекты врожденного иммунитета // Современные проблемы экологии и природопользования: Матер. регион. науч.-практ. конф., посвященной 15-летию со дня основания кафедры биоэкологии, Мурманск, 27-28 февраля 2014 г. - Мурманск: Изд-во Мурм. гос. техн. ун-та, 2014. - C. 70-74.

1217. Федоренко А.Г., Лебедева Н.В., Авилова К.В. Ультраструктурное исследование механорецепторного комплекса кончика клюва уткикряквы (предварительные данные) // Актуальные проблемы биологии, нанотехнологии и медицины: Сб. матер. VI Междунар. науч.-практ. конф. (г. Ростов-на-Дону, 1-3 октября 2015 г.). - Ростов н/Д.: Изд-во Южного фед. ун-та, 2015. - С. 284-286.

1218. Щепак Л.В., Журавлева Н.Г. Влияние температуры и солености на эмбриональное развитие рыбы чистильщика радужного губана (Labrus bergylta) [Электронный ресурс] // Наука и образование 2012: Матер. Междунар. науч.-техн. конф., Мурманск, 2-6 апреля 2012 г. Электрон. текст. дан. (30 Мб). - Мурманск: Изд-во Мурм. гос. техн. ун-та, 2012. - C. 422-425. - 1 электрон. опт. диск (CD-ROM). - Систем. требования: PC не ниже класса Pentium II; 128 Mb RAM; свободное место на HDD 130 Мб; дисковод CD-ROM 2-х и выше. - Загл. с экрана. - Электрон. текст подг. ФГБОУ ВПО «МГТУ». - № гос. регистрации 0321201101.

1219. Щепак Л.В., Журавлева Н.Г., Оттесен О. Изучение влияния различных температур и солености на эмбриональное развитие оплодотворенной икры рыбы чистильщика радужного губана (Labrus bergylta) // Экологическая безопасность приморских регионов (порты, берегозащита, рекреация, марикультура): Матер. Междунар. науч. конф., посвященной 150-летию Н.М. Книповича (Ростов-на-Дону, 5-8 июня 2012 г.). - Ростов н/Д.: Изд-во ЮНЦ РАН, 2012. - С. 283-286.

1220. Amin A., Ottesen O., Zhuravleva N. Histology of the atlantic cod. A colour Atlas. - Licentia: Universitet of Nurland. Publ., 2012. - 245 p.

1221. Embryonic development in ballan wrasse Labrus bergylta / J.D. Arcy, E. Dunaevskaya, J.W. Treasurer, O. Ottesen, J. Maguire, N. Zhuravleva, A. Karlsen, C. Rebours, R.D. FitzGerald // J. Fish Biology. - 2012. - Vol. 81, iss. 3. - P. 1101-1110. - Doi: 10.1111/j.1095-8649.2012.03337.x. 
1222. Fedotova L.V., Zhuravleva N.G., Ottesen O.H. Investigation of the body malformations of the newly hatched larvae of Labrus bergilta reared at different temperature and salinity during the embryonic development [Электронный ресурс] // Охрана окружающей среды и здоровья человека в Российской Федерации и странах Евросоюза: Матер. Междунар. науч.-практ. конф., Мурманск, 31 окт. 2014 г. Электрон. текст. дан. (5.15 Мб). - Мурманск: Изд-во Мурм. гос. техн. ун-та, 2014. - С. 214-221. - 1 электрон. опт. диск (CD-ROM). - Систем. требования: PC не ниже класса Pentium II; 128 Mb RAM; Windows 9xWindows 8; свободное место на HDD 131 Мб; дисковод CD-ROM 2-х и выше. - Загл. с экрана. - Электрон. текст подг. ФГБОУ ВПО «МГТУ».

1223. Kozyrenko E.A., Salmova N.A., Zhuravleva N. Thymus morphology at early ontogenetic stages of atlantic cod, Gadus morhua L. [Электронный ресурс] // Наука и образование - 2012: Матер. Междунар. науч.-техн. конф., Мурманск, 2-6 апреля 2012 г. - Электрон. текст. дан. (30 Мб). - Мурманск: Изд-во Мурм. гос. техн. ун-та, 2012. - С. 389-391. 1 электрон. опт. диск (CD-ROM). - Систем. требования: PC не ниже класса Pentium II; 128 Mb RAM; свободное место на HDD 130 Мб; дисковод CD-ROM 2-х и выше. - Загл. с экрана. - Электрон. текст подг. ФГБОУ ВПО «МГТУ». - № гос. регистрации 0321201101.

1224. Ottesen O.H., Zhuravleva N., Amin A.B. Histology of atlantic cod - Early stages. A colour atlas. - Licentia: Universitet of Nurland. Publ., 2015. - $360 \mathrm{p}$.

1225. Shchepak L.V., Zhuravleva N.G. The study of the early development of the most promising cleaner fish Labrus bergylta (Ballan Wrasse) [Электронный ресурс] // Наука и образование - 2014: Матер. Междунар. науч.-техн. конф., Мурманск, 24-28 марта 2014 г. Электрон. текст. дан. - Мурманск: Изд-во Мурм. гос. техн. ун-та, 2014. C. 1017-1020. - 1 электрон. опт. диск (CD-ROM). - Систем. требования: PC не ниже класса Pentium II; 128 Mb PAM; свободное место на HDD $100 \mathrm{Mb}$; Adobe Acrobat Reader; дисковод CD-ROM 2-х и выше. - Загл. с экрана. - Электрон. текст подг. ФГБОУ ВПО «МГТУ». - № гос. регистрации 0321401155.

1226. Shchepak L.V., Zhuravleva N.G., Ottesen O. Effects of different conditions of incubation on appearance of the main deformations of Ballan wrasse (Labrus bergylta) larvae after hatching [Электронный ресурс] // Наука и образование - 2013: Матер. Междунар. науч.-техн. конф., Мурманск, 4-11 марта 2013 г. - Электрон. текст. дан. (220 Мб). - Мурманск: Изд-во Мурм. гос. техн. ун-та, 2013. - С. 966-970. - 1 электрон. опт. диск (CDROM). - Систем. требования: PC не ниже класса Pentium II; $128 \mathrm{Mb}$ RAM; свободное место на HDD $130 \mathrm{Mb}$; дисковод CD-ROM 2-х и выше. - Загл. с экрана. - Электрон. текст подг. ФГБОУ ВПО «МГТУ». № гос. регистрации 0321301202 . 


\section{ОБЩИЕ ВОПРОСЫ ЭКОЛОГИИ АРКТИЧЕСКИХ И ЮЖНЫХ МОРЕЙ}

1227. Бардан С.И., Сербов Н.Г. Формирование бимодального сценария сукцессии автотрофных компонент планктона в Баренцевом и Черном морях и оценка роли температурного фактора // Вісник Одеського екологічного державного університету. - 2013. - Вип. 16. - С. 90-114.

1228. Биоресурсы арктических морей России: современное состояние, влияние природных изменений и антропогенных воздействий, научные основы и перспективы использования [Электронный ресурс] / Г.Г. Матишов, М.В. Макаров, А.Г. Двореикий, Е.И. Дружкова, Г.В. Ильин, Н.Н. Кавиевич, О.В. Карамушко, Ю.В. Краснов, О.С. Любина, Д.В. Моисеев, А.А. Шавыкин, C.В. Бердников // Программа Президиума РАН «Поисковые фундаментальные научные исследования в интересах развития Арктической зоны Российской Федерации» на 2014 год. - М.: PAH, 2014 г. - 12 с. - URL: http://www.ras.ru/viewstaticdoc.aspx? $\mathrm{id}=6 \mathrm{fa} 0 \mathrm{e} 4 \mathrm{e} 3-9753-428 \mathrm{~b}-\mathrm{a} 447$ 1 befb $815 \mathrm{~cd} 93 \&$ Language $=$ ru

1229. Большие морские экосистемы шельфовых морей российской Арктики / Г.Г. Матишов, В.В. Денисов, С.Л. Дженюк, П.Р. Макаревич // Наземные и морские экосистемы. - М.; СПб.: Paulsen, 2011. - С. 71-97.

1230. Влияние пастбищной нагрузки на трансформацию сухостепных экосистем в долине Маныча / Н.В. Лебедева, Л.П. Ильина, А.В. Пономарев, Р.М. Савииякии // Аридные экосистемы. - 2011. - Т. 17, № 4(49). - C. 83-94.

1231. Гаргопа Ю.М. Реакция отдельных компонентов экосистемы Черного моря на изменения характера климатообразующих процессов // Вопросы промысловой океанологии. - 2010. - Т. 7, вып. 1. - С. 45-70.

1232. Дворецкий А.Г. Вселение камчатского краба в Баренцево море и его воздействие на экосистему (обзор). 4. Промысел и социальноэкономические аспекты // Вопросы рыболовства. - 2014. - Т. 15, № 1(57). - C. 7-20.

1233. Доклад о состоянии и об охране окружающей среды Мурманской области в 2010 году / С.И. Ахметшина, В.Ш. Баркан, Е.В. Бреславеи, С.В. Булатова, И.В. Вдовин, С.В. Волочин, К.В. Востряков, Р.И. Гайнанова, С.Г. Генералов, О.Б. Гонтарь, Т.С. Гоппен, О.Н. Гроголь, Г.М. Дьячкова, А.П. Зайчев, А.В. Зубарева, Ю.В. Иванов, А.С. Игнатьев, В.И. Игнатенко, Г.В. Ильин, О.П. Киричек, А.Н. Кольиова, И.Б. Конюхов, Т.Д. Короткова, В.В. Королев, А.С. Корякин, Т.С. Куликова, Н.А. Лесихина, Л.А. Лукичева, А.Н. Маслов, О.Г. Микляева, О.А. Носарева, В.Р. Охотник, П.В. Пестов, Н.В. Поликарпова, Ю.В. Полищук, И.В. Ратомская, Н.М. Савчис, А.В. Семенов, 
И.С. Сидорова, В.И. Смирнов, Е.Н. Сусленкова, А.А. Смирнов, О.К. Суткайтис, Н.М. Суханова, В.М. Хруикий, Ю.В. Фундератов, А.С. Чавгун, Н.И. Чупрова, И.Н. Шахова, О.Г. Шипилова, М.В. Шулина. - Мурманск: ООО «Рекламное агентство XXI век», 2011. - 160 c. - URL: http://www.gov-murman.ru/envcond/

1234. Доклад о состоянии и об охране окружающей среды Мурманской области в 2011 году / А.Р. Анцифферова, Н.А. Беляевская, В.Ш. Баркан, Т.С. Баева, С.В. Булатова, С.В. Буханиева, И.В. Вдовин, О.А. Вишневская, С.В. Волошин, Е.В. Воронова, Р.И. Гайнанова, С.Г. Генералов, Т.Н. Голубева, О.Б. Гонтарь, Т.С. Гоппен, О.Н. Гроголь, И.Д. Данилов, Н.С. Дмитриева, А.В. Зубков, В.С. Знаенко, М.Н. Зуева, Ю.В. Иванов, В.И. Игнатенко, Г.В. Ильин, О.П. Киричек, А.Н. Кольчова, Т.Д. Короткова, В.В. Королев, А.С. Корякин, А.Н. Курчак, Л.В. Лапинскайтене, М.В. Левченко, Н.А. Лесихина, Л.А. Лукичева, А.Н. Маслов, Л.А. Николаева, А.Н. Новикова, О.А. Носарева, В.Р. Охотник, О.А. Подольская, Ю.В. Полищук, И.В. Ратомская, Т.М. Рыюжкова, Н.М. Савчис, А.В. Семенов, И.С. Сидорова, В.И. Смирнов, Е.Н. Сусленкова, А.А. Смирнов, О.К. Суткайтис, М.Г. Утробин, В.М. Хруикий, А.С. Чавгун, Н.И. Чупрова, И.Н. Шахова, С.В. Шаманский, М.В. Шулина, A.А. Яшкина. - Мурманск: ООО «Ростсервис», 2012. - 160 с. - URL: http://www.gov-murman.ru/envcond/

1235. Доклад о состоянии и об охране окружающей среды Мурманской области в 2012 году / Л.Е. Александрова, В.Ш. Баркан, С.В. Буханщева, И.В. Вдовин, О.А. Вишневская, С.В. Волошин, С.Г. Генералов, О.Б. Гонтарь, Т.С. Гоппен, И.Д. Данилов, М.В. Даувальтер, А.П. Зайџев, В.В. Загудеева, Ю.В. Иванов, Г.В. Ильин, А.В. Киреева, О.П. Киричек, Т.Д. Короткова, М.Р. Краевская, В.В. Королев, А.С. Корякин, Е.Н. Кругликова, Л.В. Лапинскайтене, М.В. Левченко, Л.А. Лукичева, С.В. Малашенко, Э.В. Макарова, О.А. Носарева, В.Р. Охотник, Н.И. Подольский, М.А. Петроченкова, Ю.В. Печерская, О.А. Подольская, Н.В. Поликарпова, К.Ю. Ракитенко, О.З. Решетова, Т.М. Рыюжкова, М.В. Рыжсов, С.И. Русских, В.В. Серветник, А.А. Сергеев, И.С. Сидорова, В.И. Смирнов, Е.Н. Сусленкова, А.А. Смирнов, О.К. Суткайтис, И.В. Ткачук, М.Г. Трусова, М.Г. Утробин, М.Ю. Уткин, А.С. Чавгун, Н.И. Чупрова, Ю.В. Шандарова, С.В. Шаманский, М.В. Шулина, А.А. Яшкина, О.А. Юрьева, А.Р. Анциферова, М.Н. Зуева. Мурманск: ИП Щербаков М.Л., 2013. - 160 c. - URL: http://www.govmurman.ru/envcond/.

1236. Доклад о состоянии и об охране окружающей среды Мурманской области в 2013 году / Д.Б. Аверкиев, Л.Е. Александрова, А.В. Алексеев, В.И. Антонов, В.Ш. Баркан, Н.А. Беляевская, П.В. Богданов, И.В. Вдовин, С.В. Волошин, О.Б. Гонтарь, Д.Л. Демченко, М.В. Даувальтер, А.А. Золотков, А.П. Зайчев, Г.Г. Иванова, Г.В. Ильин, А.Х. Ильясов, В.В. Йокубаускас, Е.В. Койпиш, И.Б. Конюхов, Т.Д. Короткова, В.В. Королев, Е.Н. Кругликова, Л.А. Лукичева, Е.С. Макарова, Э.В. Макарова, А.С. Меренков, Е.Н. Меренкова, О.А. Носарева, Т.В. Опря, П.В. Пестов, Ю.В. Печерская, О.А. Подольская, 
Н.В. Поликарпова, О.И. Прокина, Т.М. Рыжкова, Р.В. Самохин, B.В. Серветник, А.А. Сергеев, И.С. Сидорова, А.А. Смирнов, В.И. Смирнов, В.Н. Соснина, Е.Н. Сусленкова, О.К. Суткайтис, Е.Л. Толмачева, С.И. Телятник, К.Ю. Турищева, М.Г. Утробин, А.В. Фролов, Р.И. Хардикова, Е.В. Хлопиева, А.С. Чавгун, М.М. Чупрова, Н.И. Чупрова, И.Н. Шахова, A.В. Шиловский, О.А. Юрьева. - Мурманск: ИП Кузнецов Н.В., 2014. 160 c. - URL: http://mpr.gov-murman.ru/07.eco/00.condition/condit.html

1237. Доклад о состоянии и об охране окружающей среды Мурманской области в 2014 году / Д.Б. Аверкиев, Л.Е. Александрова, А.В. Алексеев, В.В. Алексеева, М.А. Амахина, О.В. Анисимова, Е.Г. Антонова, М.М. Ахметова, В.Ш. Баркан, Н.А. Беляевская, Н.Г. Берлина, П.В. Богданов, Е.А. Боровичев, В.Е. Бранько, С.В. Булатова, И.В. Вдовин, О.А. Вишневская, С.В. Волошин, Р.И. Гайнанова, О.Б. Гонтарь, О.В. Горемькина, О.Н. Гроголь, Д.Л. Демченко, М.В. Даувальтер, М.О. Ершов, Н.В. Заборщиков, В.В. Заборшикова, А.А. Золотков, А.П. Зайщев, Г.Г. Иванова, Г.В. Ильин, А.Х. Ильясов, В.В. Йокубаускас, Т.Б. Киричек, Е.В. Койпиш, И.Б. Конюхов, Т.Д. Короткова, В.В. Королев, Е.Н. Кругликова, М.В. Левченко, Л.А. Лукичева, Е.С. Макарова, Э.В. Макарова, А.С. Меренков, Е.Н. Меренкова, О.А. Носарева, Т.В. Опря, В.Р. Охотник, П.В. Пестов, М.А. Петроченкова, Ю.В. Печерская, О.А. Подольская, Н.В. Поликарпова, О.И. Прокина, Ю.В. Романова, Т.М. Рызжкова, Р.В. Самохин, Н.Ю. Самсонова, В.В. Серветник, А.А. Сергеев, В.И. Смирнов, В.Н. Соснина, Е.Н. Сусленкова, О.К. Суткайтис, Е.Л. Толмачева, С.И. Телятник, К.Ю. Турищева, М.Г. Утробин, А.В. Фролов, Р.И. Хардикова, Е.В. Хлопиева, И.В. Цветкова, А.С. Чавгун, М.М. Чупрова, Н.И. Чупрова, Ю.В. Шандарова, И.Н. Шахова, А.В. Шиловский, О.Н. Ширшова, О.А. Юрьева, А.А. Яшкина. - Мурманск: Изд. Мин-ва природ. ресурсов и экологии Мурманской обл., 2017. - 177 с. - URL: http://mpr.gov-murman.ru/activities/00.condition/

1238. Ишкулов Д.Г., Горяев Ю.И. Результаты наблюдений за птицами и морскими млекопитающими в Обской и Тазовской губах в поздне-летний период 2014 г. // Арктическое морское природопользование в XXI веке - современный баланс научных традиций и инноваций (к 80-летию ММБИ КНЦ РАН): Тез. докл. Междунар. науч. конф. (г. Мурманск, 1-3 апреля 2015 г.). - Апатиты: Изд-во КНЦ РАН, 2015. - С. 90-91.

1239. Керченский пролив в осенний период 2011 года: результаты совместных комплексных исследований, выполненных в экспедиции МГИ НАН Украины и ЮНЦ РАН / В.А. Иванов, Г.Г. Матишов, В.М. Кушнир, С.В. Бердников, А.И. Чепьюженко, В.В. Поважный, О.В. Степаньян // Мор. гидрофиз. журн. - 2014. - № 1. - С. 44-57.

1240. Краснов Ю.В., Гаврило М.В., Спиридонов В.А. Ледовые биотопы юго-восточной части Баренцева и Белого морей // Атлас биологического разнообразия морей и побережий российской Арктики. М.: Изд. WWF России, 2011. - С. 32-33. 
1241. Ларионов В.В. Потребление зоопланктоном пелагических микроводорослей в течение суток на мелководье Норвежского моря в осенний период // Актуальные проблемы планктонологии: Тез. докл. II Междунар. конф. с таксономическим тренингом для молодых ученых (г. Светлогорск, Калининградская область, 14-18 сентября 2015 г.). Калининград: Изд-во Калининг. гос. техн. ун-та, 2015. - С. 57-58.

1242. Лебедева Н.В. Ави-вектор распространения почвенных животных на полярные острова: обзор // Тр. Кольского науч. центра РАН. - 2013. - Т. 1(14). - Сер. Океанология. - Вып. 1. - С. 152-161.

1243. Ледовое сообщество микроводорослей в Таганрогском заливе Азовского моря / Г.В. Ковалева, В.В. Поважный, А.Е. Золотарева, П.Р. Макаревич, Д.Г. Матишов // Океанология. - 2014. - Т. 54, № 5. C. 659-664.

1244. Макаревич П.Р. Морская биота арктических экосистем в условиях изменений глобального климата и антропогенного воздействия // Экологические проблемы северных регионов и пути их решения: Матер. V Всерос. науч. конф. с междунар. участием. Апатиты: Изд-во КНЦ РАН, 2014. - Ч. 1. - С. 30-32.

1245. Макаревич П.Р., Ишкулов Д.Г. Влияние климатических факторов на структуру и видовое разнообразие пелагических и донных биоценозов Баренцева моря // Наземные и морские экосистемы. - М.; СПб.: Paulsen, 2011. - С. 151-165.

1246. Матишов Г.Г. Перспективы освоения Мирового океана и арктических морей // Морские животные на службе человеку: Матер. науч.-практ. семинара (4 октября 2010 г., Североморск). - Ростов н/Д.: Изд-во ЮНЦ РАН, 2011. - С. 5-16.

1247. Матишов Г.Г. Фундаментальные проблемы арктических и аридных экосистем // Изучение и освоение морских и наземных экосистем в условиях арктического и аридного климата: Матер. Междунар. науч. конф. (6-11 июня 2011 г., Ростов-на-Дону). - Ростов н/Д.: Изд-во ЮНЦ РАН, 2011. - С. 5-12.

1248. Матишов Г.Г. Заключение // Комплексные исследования больших морских экосистем России. - Апатиты: Изд-во КНЦ РАН, 2011. - C. 465-467.

1249. Матишов Г.Г. Социально-экономические и экологические проблемы Арктики // Инновации как фактор устойчивого развития Арктики: Тез. докл. Междунар. науч.-практ. конф. (25-26 ноября 2010 г., Ямало-Ненецкий АО, г. Салехард). - Б.м., 2011. С. 177-180.

1250. Матишов Г.Г. Климат и океанологические исследования северных и южных морей // Научно-технические проблемы освоения Арктики. - М.: Наука, 2015. - С. 298-306. 
1251. Матишов Г.Г. Фундаментальные и прикладные исследования арктических морей в интересах экономики и безопасности // Арктическое морское природопользование в XXI веке - современный баланс научных традиций и инноваций (к 80-летию ММБИ КНЦ РАН): Тез. докл. Междунар. науч. конф. (г. Мурманск, 1-3 апреля 2015 г.). Апатиты: Изд-во КНЦ РАН, 2015. - С. 5-7.

1252. Матишов Г.Г., Дженюк С.Л. Арктические вызовы и проблемы полярной науки // Вестн. РАН. - 2012. - Т. 82, № 10. - С. 921-929.

1253. Матишов Г.Г., Дженюк С.Л. Природно-экономическая система Севморпути как объект комплексных исследований // Освоение Арктики. История и современность: Матер. науч.-практ. конф., 14-15 ноября 2013 г. - Мурманск: Б.и., 2013. - С. 103-108.

1254. Матишов Г.Г., Дюсенюк С.Л. Научные изыскания в Арктике // Арктический регион. Проблемы международного сотрудничества: В 3-х т. - М.: Аспект Пресс, 2013. - Т. 2. - С. 324-343.

1255. Матишов Г.Г., Ишкулов Д.Г. Экспедиционные исследования Мурманского морского биологического института КНЦ РАН, проведенные в рамках Международного полярного года 2007/08 // Наземные и морские экосистемы. - М.; СПб.: Paulsen, 2011. - С. 15-59.

1256. Матишов Г.Г., Матишов Д.Г. Основные направления морских экосистемных исследований Мурманского морского биологического института в Арктике // Тр. Кольского науч. центра РАН. - 2013. Т. 1(14). - Сер. Океанология. - Вып. 1. - С. 25-42.

1257. Матишов Г.Г., Степаньян О.В. В Азовском море и зимой кипит жизнь // Природа. - 2013. - № 3. - С. 20-23.

1258. Матишов Г.Г., Болтачев А.Р., Степаньян О.В. Введение // Вселенцы в биоразнообразии и продуктивности Азовского и Черного морей. - Ростов н/Д.: Изд-во ЮНЦ РАН, 2010. - С. 7-8.

1259. Матишов Г.Г., Болтачев А.P., Степаньян О.В. Заключение // Вселенцы в биоразнообразии и продуктивности Азовского и Черного морей. - Ростов н/Д.: Изд-во ЮНЦ РАН, 2010. - С. 114-115.

1260. Матишов Г.Г., Балыкин П.А., Жичкин А.П. Биологические ресурсы моря и пресноводных водоемов // Богатства России. - М.: Календа, 2012. - С. 218-223.

1261. Матишов Г.Г., Дженюк С.Л., Брехунщов А.М. Исследования Карского моря на современном этапе освоения российской Арктики // Арктика: экология и экономика. - 2013. - № 1(9). - С. 4-11.

1262. Матишов Г.Г., Дженюк С.Л., Тарасов Г.А. Актуальные проблемы изучения природы архипелага Шпицберген и прилегающих 
вод // Комплексные исследования природы Шпицбергена и прилегающего шельфа: Матер. Междунар. науч. конф. (Мурманск, 6-8 ноября 2014 г.). Вып. 12. - М.: ГЕОС, 2014. - С. 5-7.

1263. Матишов Г.Г., Макаревич П.Р., Ильин Г.В. Структура и современное функционирование баренцевоморской экосистемы // Комплексные исследования больших морских экосистем России. Апатиты: Изд-во КНЦ РАН, 2011. - С. 91-116.

1264. Матишов Г.Г., Макаревич П.Р., Ишкулов Д.Г. Влияние климата и антропогенных факторов на морские экосистемы Арктики // Материалы совместного заседания Совета РАН по координации деятельности региональных отделений и региональных научных центров РАН и Научного совета РАН по изучению Арктики и Антарктики, 31 марта-2 апреля 2010 г., г. Архангельск. - Екатеринбург: Изд-во УрО PAH, 2010. - C. 103-116.

1265. Матишов Г.Г., Макаревич П.Р., Ишкулов Д.Г. «Вселенцы» и «невселенцы»: причины и последствия их появления // Изв. Самар. науч. центра РАН. - 2011. - Т. 13, № 1(6). - С. 1357-1366.

1266. Матишов Г.Г., Макаревич П.Р., Моисеев Д.В. Кольский разрез в полярную ночь // Российские полярные исследования: Информ.-аналит. сб. - 2013. - № 3(13). - С. 23-25.

1267. Матишов Г.Г., Матишов Д.Г., Степаньян О.В. Оценка современного состояния экосистемы Черного моря (Республика Абхазия) // Докл. РАН. - 2014. - Т. 454, № 6. - С. 715-719.

1268. Матишов Г.Г., Макаревич П.Р., Тарасов Г.А. Комплексные исследования ММБИ КНЦ РАН на Шпицбергене // Комплексные исследования природы Шпицбергена: Матер. Междунар. науч. конф. (Мурманск, 1-3 ноября 2012 г.). Вып. 11. - М.: ГЕОС, 2012. - С. 5-9.

1269. Особенности структуры пелагического сообщества Азовского моря в условиях аномально холодной зимы 2005-2006 гг. / Г.Г. Матишов, О.В. Степаньян, Г.В. Ковалева, В.В. Поважный, К.В. Кренева // Вестн. Южного науч. центра РАН. - 2012. - Т. 8, № 4. - С. 66-75.

1270. Особенности организации пелагиали в районе архипелага Земля Франца-Иосифа в летний период / И.В. Берченко, Е.И. Дружккова, А.А. Олейник, Т.Г. Ишкулова, М.П. Венгер // Тр. Кольского науч. центра РАН. - 2014. - Т. 4(23). - Сер. Океанология. - Вып. 2. - С. 112-150.

1271. От Шпицбергена до моря Лаптевых - научно-экспедиционные исследования ММБИ на современном этапе / Г.Г. Матишов, П.Р. Макаревич, Д.В. Моисеев, С.Л. Дженюк [Электронный ресурс] // Современные тенденции природных процессов в полярных областях Земли и 
перспективы российских полярных исследований: Тез. докл. 10-й науч. конф. (г. Сочи, 6-8 октября 2014 г.). - Сочи, 2014. - С. 82-83. - URL: http://polar2014.ru/

1272. Пантелеева Н.Н. Схема функционирования экосистемы залива Грён-фьорд (Западный Шпицберген) в летний период на примере беспозвоночных // Глобальные климатические процессы и их влияние на экосистемы арктических и субарктических регионов: Тез. докл. Междунар. науч. конф. (г. Мурманск, 9-11 ноября 2011 г.). - Апатиты: Изд-во КНЦ РАН, 2011. - С. 146-148.

1273. Роль ави-вектора в распространении беспозвоночных на удаленные арктические острова / E.H. Мелехина, Н.В. Лебедева, А.А. Таскаева, С.Дж. Коулсон, Д.Дж. Гвяздович, Т. Солхой // Проблемы изучения и охраны животного мира на Севере: Матер. докл. II Всерос. конф. с междунар. участием (Сыктывкар, Республика Коми, Россия, 8-12 апреля 2013 г.). - Сыктывкар: Изд-во Коми НЦ УрО РАН, 2013. C. 146-147.

1274. Селифонова Ж.П. Экосистемы акваторий черноморских портов Новороссийска и Туапсе. - СПб.: Наука, 2012. - 228 с.

1275. Селифонова Ж.П. Прибрежные экосистемы северо-восточного шельфа Черного моря и Азовского моря. - Новороссийск: Изд. ГМУ им. адм. Ф.Ф. Ушакова, 2014. - 170 с.

1276. Состояние прибрежных морских экосистем северо-восточного шельфа Черного моря / Ж.П. Селифонова, Ю.И. Сорокин, В.К. Часовников, O.Н. Ясакова // Комплексные исследования больших морских экосистем России. - Апатиты: Изд-во КНЦ РАН, 2011. - С. 389-398.

1277. Фаунистическое разнообразие и показатели обилия планктонных сообществ Азовского моря в июне 2014 г. / Г.Г. Матишов, С.М. Игнатьев, Ю.А. Загородняя, Т.Н. Климова, И.В. Вдодович, В.В. Саяпин, О.В. Степаньян // Вестн. Южного научн. центра РАН. - 2015. - Т. 11, № 3. - С. 81-91.

1278. Эколого-географический анализ морского побережья Ростовской области / Г.Г. Матишов, О.В. Ивлиева, Л.А. Беспалова, Л.В. Кропянко // Докл. РАН. - 2015. - Т. 460, № 1. - С. 88-92.

1279. Экосистемы Арктического шельфа в условиях современных климатических изменений / Г.Г. Матишов, С.Л. Дженюк, А.П. Жичкин, Д.В. Моисеев // Состояние арктических морей и территорий в условиях изменения климата: Тез. докл. Всерос. конф. с междунар. участием. Архангельск: Изд. дом Северного (Арктического) фед. ун-та им. М.В. Ломоносова, 2014. - С. 86-87.

1280. Algae community on temporary ice in Taganrog Bay of the Azov Sea (temporary ice microalgae community in Taganrog Bay of the Azov Sea) / G.V. Kovaleva, V.V. Povazhnyi, A.E. Zolotareva, P.R. Makarevich, D. G. Matishov // Oceanology. - 2014. - Vol. 54, № 5. - P. 618-623. 
1281. Climatic chages of marine ecosystems of the Western Arcric / G.G. Matishov, S.L. Dzhenyuk, A.P. Zhichkin, D.V. Moiseev // The Arctic in the earth system perspective: the role of tipping points: Abstr. Conf. Arctic Frontiers (26-28 January 2011, Tromsø, Norway). - Tromsø, 2011. - P. 57.

1282. Climate and cyclic hydrobiological changes in the Barents Sea in the $20^{\text {th }}$ and $21^{\text {st }}$ centuries / G. Matishov, D. Moiseev, O. Lyubina, A. Zhichkin, S. Dzhenyuk, O. Karamushko, E. Frolova [Электронный pecypc] // Effects of Climate Change on the World's Oceans: Abstr. of $2^{\text {nd }}$ Intern. Symp. (May 13-20 2012, Yeosu, Korea). - Yeosu, 2012. - S4-7968. P. 119. - URL: http://pices.int/publications/book_of_abstracts/2012-YeosuBook-of-Abstracts.pdf

1283. Climate and cyclic hydrobiological changes of the Barents Sea from the twentieth to twenty-first centuries / G. Matishov, D. Moiseev, O. Lyubina, A. Zhichkin, S. Dzhenyuk, O. Karamushko, E. Frolova // Polar Biol. - 2012. - Vol. 35. - P. 1773-1790. - Doi: 10.1007/s00300-012-1237-9 URL: http://www.springerlink.com/content/8t41515hp0052273/

1284. Ecological and geographical analysis of the Sea coast of the Rostov Region / G.G. Matishov, O.V. Ivlieva, L.A. Bespalova, L.V. Kropyanko // Doklady Earth Sci. - 2015. - Vol. 460, № 1. - P. 53-57.

1285. Lebedeva N.V. Oribatid mites transported by birds to polar islands. A review // Berichte zur Polarforschung. - 2012. - № 640. - P. 152-161.

1286. Main bioproductivity features of the western Arctic LMEs / G.G. Matishov, P.R. Makarevich, E.I. Druzhkova, O.V. Karamushko, O.S. Lyubina // Book of Abstracts ICES Annual Science Conference (19-23 September 2011, Gdansk Music and Congress Center, Gdansk, Poland). Gdansk, 2011. - P. 141-142.

1287. Marine Lake Mogilnoe (Kildin Island, the Barents Sea): one hundred years of solitude / P. Strelkov, N. Shunatova, M. Fokin, N. Usov, M. Fedyuk, S. Malavenda, O. Lubina, A. Poloskin, S. Korsun // Polar Biol. 2014. Vol. 37. - P. 297-310. - Doi: 10.1007/s00300-013-1431-4

1288. Matishov G.G., Matishov D.G. Main problems of Arctic marine ecosystem studies of Murmansk Marine Biological Institute // Berichte zur Polarforschung. - 2012. - № 640. - P. 26-47.

1289. Matishov G.G., Matishov D.G., Stepanyan O.V. Assessment of the modern state of the Black Sea ecosystem (Republic of Abkhazia) // Doklady Earth Sci. - 2014. - Vol. 454, № 2. - P. 213-217.

1290. Planktonic community of Frans-Josef Land / I.V. Berchenko, E.I. Druzhkova, A.A. Oleynik, M.P. Venger, T.G. Ishkulova [Электронный pecypc] // Book of Abstracts $35^{\text {th }}$ polar symposium diversity and state of polar ecosystems, 4- $7^{\text {th }}$ June 2014, Wrocław. - Wrocław: Institute of Geography and Regional Development, University of Wrocław, 2014. - P. 10. - URL: http://www.geogr.uni.wroc.pl/images/publikacje/SP_2014_Abstract_book.pdf 
1291. Temporal dynamics of top predators interactions in the Barents Sea / J.M. Durant, M. Skern-Mauritzen, Y.V. Krasnov, N.G. Nikolaeva, U. Lindstrøm, A. Dolgov // PLOS ONE. - 2014. - № 9(11). - Doi: 10.1371/journal. pone.0110933. - URL: http://www.plosone.org/article/info\%3Adoi\%2F10. 1371\%2Fjournal.pone.0110933

1292. The effect of grazing intensity on the transformation of arid steppe ecosystems in the Manych valley / N.V. Lebedeva, L.P. Ilyina, A.V. Ponomarev, R.M. Savitsky // Arid Ecosystems. - 2011. - Vol. 1, № 4. - P. 251-259.

1293. The terrestrial and freshwater invertebrate biodiversity of the archipelagoes of the Barents Sea: Svalbard, Franz Josef Land and Novaya Zemlya / S.J. Coulson, P. Convey, K. Aakra, L. Aarvik, M.L. Ávila-Jiménez, A. Babenko, E.M. Biersma, S. Boström, J.E. Brittain, A.M. Carlsson, K. Christoffersen, W.H. De Smet, T. Ekrem, A. Fjellberg, L. Füreder, D. Gustafsson, D.J. Gwiazdowicz, L.O. Hansen, M. Holmstrup, M. Hullé, Ł. Kaczmarek, M. Kolicka, V. Kuklin, H.-K. Lakka, N. Lebedeva, O. Makarova, K. Maraldo, E. Melekhina, F. Ødegaard, H.E. Pilskog, J.C. Simon, B. Sohlenius, T. Solhøy, G. Søli, E. Stur, A. Tanasevitch, A. Taskaeva, G. Velle, K. Zawierucha, K. Zmudczyńska-Skarbek// Soil Biology and Biochemistry. - 2014. - Vol. 68. - P. 440-470.

\section{МОНИТОРИНГ ВОДНЫХ ЭКОСИСТЕМ}

1294. Баданин Ю.А., Дерябин А.А. Результаты экспедиции в Баренцево, Белое и Карское моря по трассе Севморпути весной 2014 г. // Арктическое морское природопользование в XXI веке современный баланс научных традиций и инноваций (к 80-летию ММБИ КНЦ РАН): Тез. докл. Междунар. науч. конф. (г. Мурманск, 1-3 апреля 2015 г.). - Апатиты: Изд-во КНЦ РАН, 2015. - С. 15.

1295. Гудимов A.B. Биосенсорные технологии обнаружения экологически опасных изменений водной среды в реальном времени: прошлое, настоящее и будущее // Изучение и освоение морских и наземных экосистем в условиях арктического и аридного климата: Матер. Междунар. науч. конф. (6-11 июня 2011 г., Ростов-на-Дону). Ростов н/Д.: Изд-во ЮНЦ РАН, 2011. - С. 41-42.

1296. Гудимов А.B. К вопросу применения он-лайн биомониторинга // Тобольск научный - 2011: Матер. VIII Всерос. науч.-практ. конф. (г. Тобольск, Россия, 11-12 ноября 2011 г.). - Тобольск: Полиграфист, 2011. - C. 44-45.

1297. Гудимов А.В. Непрерывный биомониторинг по поведенческим реакциям мидий: первый опыт в условиях Кольского залива, Баренцево море // Докл. РАН. - 2011. - Т. 439, № 1. - С. 132-134. 
1298. Гудимов A.B. Разделение нормы и патологии - основа технологий он-лайн биомониторинга и контроля токсичности вод в реальном времени // Проблемы иммунологии, патологии и охраны здоровья рыб: Расширенные матер. III Междунар. конф. (18-22 июля 2011 г., пос. Борок). - М.: Изд-во РГАУ-МСХА им. К.А. Тимирязева, 2011. - C. 24-25.

1299. Гудимов A.B. Двустворчатые моллюски морской гребешок Chlamys islandica и модиолус Modiolus modiolus - объекты биосенсорного мониторинга // Экологическая безопасность приморских регионов (порты, берегозащита, рекреация, марикультура): Матер. Междунар. науч. конф., посвященной 150-летию Н.М. Книповича (Ростов-на-Дону, 5-8 июня 2012 г.). - Ростов н/Д.: Изд-во ЮНЦ РАН, 2012. - С. 92-93.

1300. Гудимов A.B. Оперативный биомониторинг на основе биосенсоров - современная технология контроля экологической безопасности // Север промышленный. - 2012. - № 1(41). - С. 17-18.

1301. Гудимов A.B. Применение двустворчатых моллюсков в биосенсорном мониторинге // Современные проблемы экологии и природопользования: Матер. регион. науч.-практ. конф., посвященной 15-летию со дня основания кафедры биоэкологии, Мурманск, 27-28 февраля 2014 г. - Мурманск: Изд-во Мурм. гос. техн. ун-та, 2014. C. $151-155$.

1302. Гудимов А.B. Экологический биомониторинг водных экосистем: на пути к новейшим технологиям // Морские экосистемы и сообщества в условиях современных климатических изменений. - СПб.: Реноме, 2014. - C. 326-344.

1303. Гудимов A.B. Биосенсорный мониторинг и тестирование дизельного топлива по поведенеским реакциям двустворчатых моллюсков // Проблемы патологии, иммунологии и охраны здоровья рыб и других гидробионтов: Расширенные матер. IV Междунар. конф., Борок, 24-27 сентября 2015 года. - Ярославль: Филигрань, 2015. - С. 508-512.

1304. Гудимов A.B. Оперативный (онлайн) биомониторинг стратегический путь развития экологического биомониторинга // Экологическая стратегия развития прибрежных регионов: география, окружающая среда, население. Медико-экологические и социальноэкономические проблемы прибрежных регионов: Матер. Всерос. науч. конф. (г. Ростов-на-Дону, 15-18 декабря 2015 г.). - Ростов н/Д.: Изд-во ЮНЦ РАН, 2015. - С. 54-59.

1305. Гудимов А.В., Массабю Ж.-Ч. Он-лайн биомониторинг первый опыт в условиях прибрежья Баренцева моря // Юдахинские чтения. Геодинамика и экология Баренц-региона в XXI веке: Матер. докл. Всерос. конф. с междунар. участием (15-18 сентября 2014 г.). - Архангельск: Изд. Ин-та экол. проблем Севера УрО РАН, 2014. - С. 54-55. 
1306. Гудимов А.В., Массабю Ж.-Ч., Матишов Г.Г. Первый опыт непрерывного он-лайн биомониторинга в условиях прибрежья Баренцева моря // Арктическое морское природопользование в XXI веке современный баланс научных традиций и инноваций (к 80-летию ММБИ КНЦ РАН): Тез. докл. Междунар. науч. конф. (г. Мурманск, 1-3 апреля 2015 г.). - Апатиты: Изд-во КНЦ РАН, 2015. - С. 44-45.

1307. Дженюк С.Л. О совместном использовании данных дистанционного зондирования контактных измерений в океанологии // Экология. Экономика. Информатика (8-13 сентября 2013 г.): Матер. конф.: В 2-х т. Т. 2. Геоинформационные науки и экологическое развитие: новые подходы, методы, технологии. Геоинформационные технологии и космический мониторинг. - Ростов н/Д.: Изд-во Южного фед. ун-та, 2013. С. 178-181.

1308. Дженюк С.Л. К обоснованию комплексной системы мониторинга морей Западной Арктики // Вестн. Кольского науч. центра РАН. - 2015. - № 2(21). - С. 94-102.

1309. Дженюк С.Л. Физические и биологические аспекты мониторинга морских экосистем // Арктическое морское природопользование в XXI веке - современный баланс научных традиций и инноваций (к 80-летию ММБИ КНЦ РАН): Тез. докл. Междунар. науч. конф. (г. Мурманск, 1-3 апреля 2015 г.). - Апатиты: Изд-во КНЦ РАН, 2015. - С. 56-57.

1310. Калинка О.П., Шавыкин А.А. Вопросы производственного экологического мониторинга при освоении шельфа // Изучение и освоение морских и наземных экосистем в условиях арктического и аридного климата: Матер. Междунар. науч. конф. (6-11 июня 2011 г., Ростов-на-Дону). - Ростов н/Д.: Изд-во ЮНЦ РАН, 2011. - С. 57-60.

1311. Комплексные исследования в Черном и Азовском морях летом 2012 г. / Г.Г. Матишов, М.В. Набоженко, И.В. Шохин, А.Е. Золотарева, Н.И. Бульшева, В.Л. Семин, В.В. Польшин, В.В. Поважный, Р.Е. Вербиикий, Е.В. Вербицкий, Ф.В. Сапожников, В.А. Спиридонов, А.К. Залота // Океанология. - 2013. - Т. 53, № 3. - С. 418-420.

1312. Кренева К.В., Свистунова Л.Д., Кренева С.В. Оценка качества вод Кубанских лиманов с помощью индекса эвтрофирования // XI съезд Гидробиологического общества при Российской академии наук: Тез. докл., Красноярск, 22-26 сент. 2014 г. - Красноярск: Изд-во Сиб. фед. ун-та, 2014. - С. 88-90.

1313. Кренева C.В. О качестве оценок и прогнозе деградации водных экосистем (на примере крупных озер) // Вестн. Южного науч. центра РАН. - 2012. - Т.8, № 2. - С. 41-47.

1314. Кренева С.В., Кренева К.В. Состояние эвтрофных Состинских озер // Озерные экосистемы: биологические процессы, антропогенная 
трансформация, качество воды: Тез. докл. IV Междунар. науч. конф. (12-17 сент. 2011 г., Минск-Нарочь). - Минск: Изд-во Центр БГУ, 2011. - C. 25.

1315. Кренева С.В., Кренева К.В. Новые достижения и возможности в области контроля состояния водных экосистем // Современные вопросы экологического мониторинга водных и наземных экосистем: Матер. Междунар. науч. конф. молодых ученых (26-29 октября 2015, г. Ростов-на-Дону). - Ростов н/Д.: Изд. АзНИИРХ, 2015. - С. 138-143.

1316. Кренева C.B., Кренева К.В. Стремительный рост роли инфузорий в развитии методов гидроэкологии // Арктическое морское природопользование в XXI веке - современный баланс научных традиций и инноваций (к 80-летию ММБИ КНЦ РАН): Тез. докл. Междунар. науч. конф. (г. Мурманск, 1-3 апреля 2015 г.). - Апатиты: Изд-во КНЦ РАН, 2015. - С. 115-117.

1317. Кренева С.В., Кренева К.В., Головко Г.В. Оценка состояния биоценоза Миусского лимана Азовского моря // Вестн. Южного науч. центра РАН. - 2013. - Т. 9, № 4. - С. 71-77.

1318. Матишов Г.Г., Бердников С.В. Задачи создания экспериментального образца биотехнической системы мониторинга шельфовых зон морей Западной Арктики и Юга России // Арктическое морское природопользование в XXI веке - современный баланс научных традиций и инноваций (к 80-летию ММБИ КНЦ РАН): Тез. докл. Междунар. науч. конф. (г. Мурманск, 1-3 апреля 2015 г.). Апатиты: Изд-во КНЦ РАН, 2015. - С. 155-156.

1319. Матишов Г.Г., Тишков А.А. Организация и предварительные результаты исследований морских и наземных экосистем в рамках научной программы Международного полярного года 2007/08 (вместо предисловия) // Наземные и морские экосистемы. - М.; СПб.: Paulsen, 2011. - C. 3-14.

1320. Матишов Г.Г., Тишков А.А. Наземные и морские экосистемы // Итоги МПГ 2007/08 и перспективы российских полярных исследований. М.; СПб.: Paulsen, 2013. - С. 94-110.

1321. Методы контактного и спутникового мониторинга социально-экономических процессов в береговой зоне Баренцева и Белого морей / Д.В. Моисеев, П.С. Ващенко, Г.Н. Духно, О.П. Калинка // Экологическая стратегия развития прибрежных регионов: география, окружающая среда, население. Медико-экологические и социальноэкономические проблемы прибрежных регионов: Матер. Всерос. науч. конф. (г. Ростов-на-Дону, 15-18 декабря 2015 г.). - Ростов н/Д.: Изд-во ЮНЦ РАН, 2015. - С. 144-150. 
1322. Непрерывные измерения океанологических параметров в приповерхностном слое Таганрогского залива / А.А. Шавыкин, С.В. Бердников, B.B. Сапрыгин, P.E. Вербицкий // Экосистемные исследования среды и биоты Азовского бассейна. - Ростов н/Д.: Изд-во ЮНЦ РАН, 2012. C. 104-116.

1323. Облучинская Е.Д., Алешина Е.Г., Матишов Д.Г. Фукусовые водоросли как индикаторы загрязнения губ и заливов Мурмана тяжелыми металлами // Изучение и освоение морских и наземных экосистем в условиях арктического и аридного климата: Матер. Междунар. науч. конф. (6-11 июня 2011 г., Ростов-на-Дону). - Ростов н/Д.: Изд-во ЮНЦ PAH, 2011. - C. 77-79.

1324. Перспективы использования базовых продуктов ДЗ3 для комплексного экосистемного мониторинга акваторий арктических морей / К.С. Емельянов, Ю.В. Федорокова, Е.А. Морозов, О.П. Калинка, Р.Н. Клепиковский, М.Н. Петрова // Материалы XXXI конференции молодых ученых Мурманского морского биологического института, посвященной 135-летию со дня рождения К.М. Дерюгина, «Океанография и биология арктических морей» (г. Мурманск, май 2013). - Мурманск: Изд. ММБИ КНЦ РАН, 2013. - С. 70-72.

1325. Поливиева Е.И., Гудимов А.В. Мониторинг окружающей среды по поведенческим реакциям двустворчатых моллюсков [Электронный ресурс] // Наука и образование - 2014: Матер. Междунар. науч.-техн. конф., Мурманск, 24-28 марта 2014 г. - Электрон. текст. дан. - Мурманск: Изд-во Мурм. гос. техн. ун-та, 2014. - С. 1051-1054. - 1 электрон. опт. диск (CD-ROM). - Систем. требования: PC не ниже класса Pentium II; $128 \mathrm{Mb}$ PAM; свободное место на HDD $100 \mathrm{Mb}$; Adobe Acrobat Reader; дисковод CD-ROM 2-х и выше. - Загл. с экрана. - Электрон. текст подг. ФГБОУ ВПО «МГТУ». - № гос. регистрации 0321401155.

1326. Поливцева Е.И., Гудимов А.В. Приоритетные патенты в области биосенсорного мониторинга // Наука и образование в Арктическом регионе: Матер. Междунар. науч.-практ. конф., Мурманск, 6-9 апреля 2015 г. - Мурманск: Изд-во Мурм. гос. техн. ун-та, 2015. - С. 186-189.

1327. Comprehensive Studies in the Black Sea and the Sea of Azov in the summer of 2012 / G.G. Matishov, M.V. Nabozhenko, I.V. Shokhin, A.E. Zolotareva, N.I. Bulysheva, V.L. Semin, V.V. Polshin, V.V. Povazhnyi, R.E. Verbitskyi, E.V. Verbitskyi, F.V. Sapozhnikov, V.A. Spiridonov, A.K. Zalota /I Oceanology. - 2013. - Vol. 53, № 3. - P. 374-376.

1328. Kreneva S.V., Kreneva K.V. Methodology of control over the water ecosystems' statebased on the analysis of anthropogenic successions // 21 century: fundamental science and technology IV (North Charleston, USA, 10-11.11.2014). - North Charleston, 2014. - Vol. 3. - P. 1-3. 


\section{АНТРОПОГЕННОЕ ЗАГРЯЗНЕНИЕ ВОДНЫХ ЭКОСИСТЕМ И ОХРАНА ПРИРОДЫ}

1329. «Абсолютная» интегральная уязвимость акватории Кольского залива от нефти [Электронный ресурс] / А.А. Шавыкин, П.С. Ващенко, О.П. Калинка, А.Н. Карнатов // Веб-сайт «Центр компетенции по ликвидации разливов нефти в Арктике». 2014. - URL: http://osr-arctic.ru/ru/karty/ absolyutnaya-integralnaya-uyazvimost-akvatorii-kolskogo-zaliva-ot-nefti

1330. Барышникова Н.В., Павлова М.А. Влияние сточных вод на бактериальный планткон и бентос Кольского залива [Электронный ресурс] // Наука и образование - 2012: Матер. Междунар. науч.-техн. конф., Мурманск, 2-6 апреля 2012 г. - Электрон. текст. дан. (30 Мб). Мурманск: Изд-во Мурм. гос. техн. ун-та, 2012. - С. 476-480. 1 электрон. опт. диск (CD-ROM). - Систем. требования: PC не ниже класса Pentium II; 128 Mb RAM; свободное место на HDD 130 Мб; дисковод CD-ROM 2-х и выше. - Загл. с экрана. - Электрон. текст подг. ФГБОУ ВПО «МГТУ». - № гос. регистрации 0321201101.

1331. Валуйская Д.А. Океанографические основы распространения техногенных радиоизотопов Баренцева моря на примере разреза «Кольский меридиан» [Электронный ресурс] // Наука и образование 2014: Матер. Междунар. науч.-техн. конф., Мурманск, 24-28 марта 2014 г. - Электрон. текст. дан. - Мурманск: Изд-во Мурм. гос. техн. ун-та, 2014. - С. 211-214. - 1 электрон. опт. диск (CD-ROM). - Систем. требования: РС не ниже класса Pentium II; 128 Mb РАM; свободное место на HDD $100 \mathrm{Mb}$; Adobe Acrobat Reader; дисковод CD-ROM 2-х и выше. - Загл. с экрана. - Электрон. текст подг. ФГБОУ ВПО «МГТУ ». № гос. регистрации 0321401155 .

1332. Валуйская Д.А. Техногенные радионуклиды в компонентах лесных и тундровых экосистем Мурманской области // Арктическое морское природопользование в XXI веке - современный баланс научныХ традиций и инноваций (к 80-летию ММБИ КНЦ РАН): Тез. докл. Междунар. науч. конф. (г. Мурманск, 1-3 апреля 2015 г.). - Апатиты: Изд-во КНЦ РАН, 2015. - С. 24-26.

1333. Валуйская Д.А., Дерябин А.А. Радиоактивное загрязнение почвы и биоты севера Финноскандии в 2011-2012 годах // Экологоэволюционные исследования морских организмов и экосистем: Матер. XIV Междунар. науч. конф. студентов и аспирантов «Проблемы Арктического региона» (г. Мурманск, май 2014 г.). Т. I. Форум молодых ученых, посвященный 110-летию со дня рождения Ю.И. Полянского (XXXII конференция молодых ученых ММБИ). - Мурманск: Изд. ММБИ КНЦ РАН, 2014. - С. 30-36. 
1334. Ващенко П.С. Результаты оценки чувствительности береговой линии к разливам нефти по индексу ESI, материалы экспедиции по Кольскому заливу 2013 // Эколого-эволюционные исследования морских организмов и экосистем: Матер. XIV Междунар. науч. конф. студентов и аспирантов «Проблемы Арктического региона» (г. Мурманск, май 2014 г.). T. І. Форум молодых ученых, посвященный 110 -летию со дня рождения Ю.И. Полянского (XXXII конференция молодых ученых ММБИ). - Мурманск: Изд. ММБИ КНЦ РАН, 2014. - С. 37-42.

1335. Влияние аварий судов в Керченском проливе на среду и биоту / Г.Г. Матишов, Д.Г. Матишов, С.В. Бердников, Р.М. Савицкий // Физические, геологические и биологические исследования океанов и морей. - М.: Научный мир, 2010. - С. 598-612.

1336. Влияние молевого сплава на реки Пинежского бассейна / С.В. Кренева, К.В. Кренева, Е.Н. Бакаева, В.Н. Шевченко, Г.Г. Черникова, Г.Г. Толстик // Биологическое разнообразие и продуктивность водных экосистем Севера: Матер. Всерос. науч.-практ. конф., посвященной 100-летию со дня рождения заслуженного деятеля науки РС(Я), д.б.н. Ф.Н. Кириллова (г. Якутск, 15-17 ноября 2011 г.). - Якутск: Изд. ЯФ ФГУП «Госрыбцентр», 2012. - С. 181-189.

1337. Влияние радиоактивных выбросов АЭС «Фукусима-1» на среду Евро-Арктического региона / Г.В. Ильин, Н.Е. Касаткина, И.С. Усягина, Г.Г. Матишов // VII Съезд по радиационным исследованиям (радиобиология, радиоэкология, радиационная безопасность): Тез. докл., Москва, 21-24 октября 2014 г. - М.: Изд-во Рос. ун-та дружбы народов, 2014. - C. 261.

1338. Воскобойников Г.М., Пуговкин Д.В. О возможной роли Fuсиs vesiculosus в очистке прибрежных акваторий от нефтяного загрязнения // Вестн. Мурм. гос. техн. ун-та. - 2012. - Т. 15, № 4. - С. 716-720.

1339. Воскобойников Г.М., Макаров М.В., Рыжик И.В. Теоретические основы и перспективы использования плантации-биофильтра для очистки морской акватории от нефтяного загрязнения // Комплексные исследования больших морских экосистем России. - Апатиты: Изд-во КНЦ РАН, 2011. - С. 202-234.

1340. Ильин Г.В. Загрязнение среды высокоширотных районов Баренцева моря // Тезисы конференции «Комплексные и междисциплинарные исследования полярных районов» (г. Сочи, 9-11 октября 2011 г.). - Сочи: Б.и., 2011. - С. 51-52.

1341. Ильин Г.В. Накопление и распространение нефтяных углеводородов и ПАУ в Азовском море // Вестн. Южного науч. центра РАН. - 2011. - Т. 7, № 2. - С. 49-53. 
1342. Ильин Г.В. Загрязняющие вещества в атмосфере БаренцевоКарского региона // Тезисы конференции «От международного полярного года к международной полярной инициативе» (г. Сочи, 8-10 октября 2012 г.). - Сочи: Б.и., 2012. - С. 15-16.

1343. Ильин Г.В. Органические загрязнители в рыбах АзовоЧерноморского бассейна // Вестн. Южного науч. центра РАН. - 2012. T. 8, № 1. - С. 60-69.

1344. Ильин Г.В. Загрязнение воздушной среды БаренцевоКарского морского региона // Тезисы конференции «Комплексные и междисциплинарные исследования полярных районов» (г. Сочи, 7-9 октября 2013 г.). - Сочи: Б.и., 2013. - С. 17-18.

1345. Ильин Г.В. Химические загрязнители в морской среде высокоширотных архипелагов // Тр. Кольского науч. центра РАН. 2014. - Т. 4(23). - Сер. Океанология. - Вып. 2. - С. 89-102.

1346. Ильин Г.В. Распространение техногенных загрязнителей в приводном слое воздуха Баренцево-Карского региона // Современные проблемы экологии и природопользования: Матер. регион. науч.-практ. конф., посвященной 15-летию со дня основания кафедры биоэкологии, Мурманск, 27-28 февраля 2014 г. - Мурманск: Изд-во Мурм. гос. техн. ун-та, 2014. - С. 161-165.

1347. Ильин Г.В. Химические загрязнители в морской среде высокоширотных архипелагов Баренцева моря // Тезисы конференции «Современные тенденции природных процессов в полярных областях Земли и перспективы российских полярных исследований» (г. Сочи, 6-8 октября 2014 г.). - Сочи: Б.и., 2014. - С. 64.

1348. Ильин Г.В. Техногенные нагрузки и риски загрязнения окраинных морей российской Арктики // Арктическое морское природопользование в XXI веке - современный баланс научных традиций и инноваций (к 80-летию ММБИ КНЦ РАН): Тез. докл. Междунар. науч. конф. (г. Мурманск, 1-3 апреля 2015 г.). - Апатиты: Изд-во КНЦ РАН, 2015. - C. 86-88.

1349. Ильин Г.В., Голубева Н.И. Антропогенные нагрузки и риски химического загрязнения морской среды Арктики // Морские экосистемы и сообщества в условиях современных климатических изменений. СПб.: Реноме, 2014. - С. 50-76.

1350. Ильин Г.В., Громов М.С. Загрязнение аэрозолей в приводном слое атмосферы Баренцево-Карского морского региона // Глобальные климатические процессы и их влияние на экосистемы арктических и субарктических регионов: Тез. докл. Междунар. науч. конф. (г. Мурманск, 9-11 ноября 2011 г.). - Апатиты: Изд-во КНЦ РАН, 2011. - С. 80-82. 
1351. Ильин Г.В., Матишов Д.Г., Касаткина Н.Е. Формирование антропогенного загрязнения и экосистемное здоровье морей российской Арктики // Комплексные исследования больших морских экосистем России. - Апатиты: Изд-во КНЦ РАН, 2011. - С. 277-325.

1352. Ильин Г.В., Усягина И.С., Касаткина Н.Е. Геоэкологическое состояние среды морей российского сектора Арктики в условиях современных техногенных нагрузок // Вестн. Кольского науч. центра PAH. - 2015. - № 2(21). - С. 82-93.

1353. Ильин Г.В., Усягина И.С., Касаткина Н.Е. Радиоэкологическое состояние морской и наземной среды в районе губы Андреева // Атомная энергия. - 2015. - Т. 118, вып. 3. - С. 168-174.

1354. Ильин Г.В., Усягина И.С., Касаткина Н.Е. Современная оценка радиоэкологического состояния среды Карского моря (по данным 2011-2013 гг.) // Экосистема Карского моря - новые данные экспедиционных исследований: Матер. науч. конф. - М.: АПР, 2015. - С. 267-272.

1355. Искусственные радионуклиды в съедобных дикорастущих грибах и ягодах Мурманской области / Г.Г. Матишов, Н.Е. Касаткина, И.С. Усягина, Д.А. Фарион // Докл. РАН. - 2014. - Т. 455, № 5. - С. 589-594.

1356. Источники и современное распределение изотопов плутония в Баренцевом море / Н.Е. Касаткина, Г.Г. Матишов, А. Леппанен, Д.Г. Матишов, Д. Солатие // Радіобіологічні та радіоекологічні аспекти Чорнобильської катастрофи: Тез. доповідей Міжнар. конф., м. Славутич, 11-15 квітня 2011 року. - Славутич: Фітосоціоцентр, 2011. - С. 170.

1357. Касаткина Н.Е., Валуйская Д.А., Матишов Г.Г. Искусственные радионуклиды в съедобных дикорастущих грибах и ягодах Мурманской области // VII Съезд по радиационным исследованиям (радиобиология, радиоэкология, радиационная безопасность): Тез. докл., Москва, 21-24 октября 2014 г. - М.: Изд-во Рос. ун-та дружбы народов, 2014. - С. 268.

1358. Касаткина Н.Е., Салатие Д., Налбандян А. Сотрудничество России, Финляндии и Норвегии в рамках проекта «Развитие сети сотрудничества по охране окружающей среды и радиационным исследованиям европейской Арктики (CEEPRA)» // Мониторинг природных и техногенных процессов - основа предупреждения чрезвычайных ситуаций в Мурманской области: Тез. докл. науч.-практ. конф. (г. Мурманск, 15-16 мая 2012 г.). - Мурманск: Изд. ГОКУ «Управление по ГОЧС и ПБ Мурманской обл.», 2012. - С. 4-5.

1359. К оценке воздействия аварийных выбросов АЭС «Фукусима-1» на моря Западной Арктики (на примере Баренцева моря) / Г.Г. Матишов, Г.В. Ильин, Н.Е. Касаткина, И.С. Усягина, Е.В. Павельская // Докл. PAH. - 2012. - T. 446, № 4. - С. 448-452. 
1360. Кренева С.В., Кренева К.В. Соотношение некоторых структурных показателей гидробиоценозов в условиях экстремального загрязнения // Вода: химия и экология. - 2013. - № 1. - С. 87-92.

1361. Кренева С.В., Матишов Г.Г., Кренева К.В. К методологии контроля загрязнения и состояния водных экосистем // Вестн. Южного науч. центра РАН. - 2014. - Т. 10, № 4. - С. 73-79.

1362. Лебедева Н.В. Радиоэкология птиц в период между авариями в Чернобыле и Фукусиме // Изучение и освоение морских и наземных экосистем в условиях арктического и аридного климата: Матер. Междунар. науч. конф. (6-11 июня 2011 г., Ростов-на-Дону). - Ростов н/Д.: Изд-во ЮНЦ РАН, 2011. - С. 279-281.

1363. Лебедева Н.В., Панасюк H.B. Dreissena polymorpha (Pallas, 1771) в биоиндикации загрязнения вод в бассейне Азовского моря // Докл. РАН. - 2011. - Т. 436, № 4. - С. 569-573.

1364. Малавенда С.В., Шавыкин А.А., Ващзенко П.С. Биомасса макрофитобентоса и районы его наибольшей уязвимости от разливов нефти в Кольском заливе // Защита окружающей среды в нефтегазовом комплексе. - 2015. - № 12. - С. 5-12.

1365. Математическое моделирование распространения ${ }^{137} \mathrm{Cs}$ после гипотетической аварии на финской атомной станции / И.С. Усягина, Н.Е. Касаткина, Д.Г. Матишов, С.В. Бердников, Г.В. Ильин, В.В. Кульгин // Современные проблемы экологии и природопользования: Матер. регион. науч.-практ. конф., посвященной 15-летию со дня основания кафедры биоэкологии, Мурманск, 27-28 февраля 2014 г. - Мурманск: Изд-во Мурм. гос. техн. ун-та, 2014. - С. 65-70.

1366. Матишов Г.Г., Ковалева Г.В. «Цветение» воды в водоемах юга России и сбои в водоснабжении (на примере г. Волгодонска) // Цимлянское водохранилище: состояние водных и прибрежных экосистем, проблемы и пути решения. - Ростов н/Д.: Изд-во ЮНЦ РАН, 2011. C. $168-177$.

1367. Матишов Г.Г., Степаньян О.В. Комплексная оценка воздействия разливов нефтепродуктов (ноябрь 2007 г.) на экосистему Керченского пролива // Изучение и освоение морских и наземных экосистем в условиях арктического и аридного климата: Матер. Междунар. науч. конф. (6-11 июня 2011 г., Ростов-на-Дону). - Ростов н/Д.: Изд-во ЮНЦ РАН, 2011. - С. 69-71.

1368. Матишов Г.Г., Инжебейкин Ю.И., Савицкий Р.М. Воздействие на среду и биоту аварийного разлива нефтепродуктов в Керченском проливе в ноябре 2007 г. // Водные ресурсы. - 2013. - Т. 40, № 3. C. 259-273. 
1369. Матишов Г.Г., Ильин Г.В., Усягина И.С. Оценка радиоэкологического состояния и современные риски радионуклидного загрязнения Карского моря // Тезисы конференции «Итоги и перспективы изучения природной среды российской Арктики и других полярных областей» (г. Сочи, 5-7 октября 2015 г.) - Сочи: Б.и., 2015. - С. 16.

1370. Матишов Г.Г., Усягина И.С., Матишов Д.Г. Антропогенная радиоактивность морей Западной Арктики в 2010-2014 гг. // Арктическое морское природопользование в XXI веке - современный баланс научных традиций и инноваций (к 80-летию ММБИ КНЦ РАН): Тез. докл. Междунар. науч. конф. (г. Мурманск, 1-3 апреля 2015 г.). - Апатиты: Изд-во КНЦ РАН, 2015. - С. 160-162.

1371. Матишов Г.Г., Усягина И.С., Польшин В.В. Динамика загрязнения Азовского моря изотопом ${ }^{137} \mathrm{Cs}$ в 1966-2013 гг. // Докл. PAH. - 2015. - T. 460, № 6. - C. 716-721.

1372. Методы прогнозирования загрязнения нефтью побережья Азовского моря в случае аварийных разливов при транспортировке судами / С.В. Бердников, А.А. Шавыкин, В.В. Кульгин, Н.А. Яиџкая // Экология. Экономика. Информатика: В 3-х т. Т. 1. Системный анализ и моделирование экономических и экологических систем. - Ростов н/Д.: Изд-во Южного фед. ун-та, 2015. - С. 59-64.

1373. Международное сотрудничество по охране окружающей среды и радиационным исследованиям европейской Арктики / Г.Г. Матишов, Н.Е. Касаткина, И.С. Усягина, Г.В. Ильин, Д.В. Моисеев, С.В. Бердников // Арктическое морское природопользование в XXI веке - современный баланс научных традиций и инноваций (к 80-летию ММБИ КНЦ РАН): Тез. докл. Междунар. науч. конф. (г. Мурманск, 1-3 апреля 2015 г.). Апатиты: Изд-во КНЦ РАН, 2015. - С. 158-160.

1374. Многолетняя динамика радиоактивного загрязнения Баренцево-Карского региона (1960-2013 гг.) / Г.Г. Матишов, Д.Г. Матишов, И.С. Усягина, Н.Е. Касаткина // Докл. РАН. - 2014. - Т. 458, № 4. C. 473-479.

1375. Новые данные о содержании изотопов плутония в грунтах Баренцева моря / Г.Г. Матишов, Н.Е. Касаткина, А.П. Леппанен, Д.Г. Матишов, Д. Солатие // Докл. РАН. - 2011. - Т. 440, № 5. C. 696-700.

1376. Облучинская Е.Д., Алешина Е.Г., Матишов Д.Г. Сравнительная оценка загрязнения металлами губ и заливов Мурмана по индексу MPI (Metal pollution index) // Докл. РАН. - 2013. - Т. 448, № 5. - С. 588-591.

1377. О влиянии аварийного выброса АЭС «Фукусима-1» на радиационное загрязнение Баренцева моря / Г.В. Ильин, Н.Е. Касаткина, 
И.С. Усягина, Е.В. Павельская // Мониторинг природных и техногенных процессов - основа предупреждения чрезвычайных ситуаций в Мурманской области: Тез. докл. науч.-практ. конф. (г. Мурманск, 15-16 мая 2012 г.). Мурманск: Изд. ГОКУ «Управление по ГОЧС и ПБ Мурманской обл.», 2012. - C. 10-11.

1378. Оценка потоков ${ }^{137} \mathrm{Cs}$ и ${ }^{90} \mathrm{Sr}$ в Баренцевом море / Г.Г. Матишов, Д.Г. Матишов, И.С. Усягина, Н.Е. Касаткина, Е.В. Павельская // Докл. PAH. - 2011. - Т. 439, № 6. - С. 822-827.

1379. Оценка уязвимости морских млекопитающих при проведении экологических экспертиз хозяйственного освоения морского шельфа на примере юго-восточной части Баренцева моря / A.Н. Болтунов, Ю.А. Горбунов, А.А. Кондаков, Л.Р. Лукин, Д.Т. Менис, Г.Н. Огнетов, B.Н. Светочев, В.С. Семенова // Морские млекопитающие Голарктики 2012: Сб. науч. тр. по матер. VII Междунар. конф. (г. Суздаль, 24-28 сентября 2012 г.). - М.: РОО «Совет по морским млекопитающим», 2012. - T. 1. - C. 105-109.

1380. Распространение взвеси и ее воздействие на биоту при дноуглублении в Кольском заливе (Баренцево море). 1. Исходные данные и используемые модели / К.А. Клеванный, Е.В. Смирнова, А.А. Шавыкин, П.С. Ващенко // Защита окружающей среды в нефтегазовом комплексе. 2013. - № 3. - С. 18-24.

1381. Распространение взвеси и ее воздействие на биоту при дноуглублении в Кольском заливе (Баренцево море). 2. Результаты моделирования в районе дноуглубления / К.А. Клеванный, Е.В. Смирнова, А.А. Шавыкин, П.С. Ващенко // Защита окружающей среды в нефтегазовом комплексе. - 2013. - № 3. - С. 24-31.

1382. Распространение взвеси и ее воздействие на биоту при дноуглублении в Кольском заливе (Баренцево море). 3. Результаты моделирования при дампинге / К.А. Клеванный, Е.В. Смирнова, Е.В. Шавыкин, П.С. Ващенко // Защита окружающей среды в нефтегазовом комплексе. 2013. - № 3. - С. 31-39.

1383. Результаты измерений тяжелых металлов в атмосферных аэрозолях в открытых районах арктических морей в 2009-2010 гг. / Н.И. Голубева, Л.В. Буриева, Г.Г. Матишов, Г.В. Ильин // Докл. РАН. 2013. - Т. 453, № 1. - С. 72-75.

1384. Савицкий Р.М. Памятники природы как условия существования орнитофауны // Сохранение разнообразия животных и охотничье хозяйство России: Тез. докл. 4-й Междунар. науч.-практ. конф. (Москва, 17-18 февраля 2011 г.). - М.: Изд-во РГАУ-МСХА им. К.А. Тимирязева, 2011. - C. 123-124. 
1385. Сеть сотрудничества для радиационных исследований и охраны окружающей среды европейской Арктики от радиации (CEEPRA): Итоговый отчет / А.-П. Лепппнен, Т. Расилайен, К. Ваарамаа, Я. Юлипети, Н. Касаткина, Г. Матишов, И. Усягина, Г. Ильин, Д. Гвинн, М. Иоспье, Б. Мёллер, А. Налбандян, Ю. Паатеро, Ю. Вира, М. Нисси, К. Рейникайнен, Й. Бартниикий, Х. Кляйн / Под ред. Т. Расилайен. - Ювяскюля, Финляндия: Копиювя, 2014. - 44 с.

1386. Современная оценка радиоэкологического состояния среды Карского моря / Г.Г. Матишов, Г.В. Ильин, И.С. Усягина, Д.А. Валуйская // Тезисы конференции «Современные тенденции природных процессов в полярных областях Земли и перспективы российских полярных исследований» (г. Сочи, 6-8 октября 2014 г.) - Сочи, Б.и., 2014. - С. 65.

1387. Современная радиоэкологическая нагрузка на морскую среду Западной Арктики / Г.Г. Матишов, Д.Г. Матишов, Г.В. Ильин, H.Е. Касаткина, И.С. Усягина // Морские экосистемы и сообщества в условиях современных климатических изменений. - СПб.: Реноме, 2014. - C. 76-98.

1388. Современное радиоактивное загрязнения морских и наземных экосистем Евро-Арктического региона / Н.Е. Касаткина, И.С. Усягина, Г.Г. Матишов, Г.В. Ильин, Д.А. Валуйская // Современные проблемы экологии и природопользования: Матер. регион. науч.-практ. конф., посвященной 15-летию со дня основания кафедры биоэкологии, Мурманск, 27-28 февраля 2014 г. - Мурманск: Изд-во Мурм. гос. техн. ун-та, 2014. - С. 177-181.

1389. Современное состояние радиоактивного загрязнения морских экосистем Баренцево-Карского региона / Г.Г. Матишов, Д.Г. Матишов, И.С. Усягина, Д.А. Валуйская // VII Съезд по радиационным исследованиям (радиобиология, радиоэкология, радиационная безопасность): Тез. докл., Москва, 21-24 октября 2014 г. - М.: Изд-во Рос. ун-та дружбы народов, 2014. - C. 295.

1390. Современное радиоактивное загрязнение наземных экосистем Кольского полуострова / Д.А. Валуйская, Г.В. Ильин, Н.Е. Касаткина, И.С. Усягина // Pontus Euxinus 2015: Тез. IX Всерос. науч.-практ. конф. молодых ученых (с междунар. участием) по проблемам водных экосистем, посвященной 100 -летию со дня рождения д.б.н., проф., чл.-корр. АН УССР В.Н. Грёзе (17-20 ноября 2015 г.). - Севастополь: DigitPrint, 2015. - C. 33-34.

1391. Современные данные по загрязнению Азовского и Черного морей углеводородами нефти / Г.Г. Матишов, О.В. Степаньян, B.M. Харьковский, В.Г. Сойер // Вестн. Южного науч. центра РАН. 2014. - T. 10, № 4. - C. 49-52. 
1392. Усягина И.С. Распределение и пути миграций искусственных радионуклидов в экосистеме Баренцева моря: Автореф. дис. ... канд. геогр. наук (25.00.28 - океанология). - Мурманск, 2012. - 23 с.

1393. Усягина И.С. Реконструкция потоков ${ }^{137} \mathrm{Cs}$ и ${ }^{90} \mathrm{Sr}$ в Карском море (1960-2013 гг.) // Арктическое морское природопользование в XXI веке - современный баланс научных традиций и инноваций (к 80-летию ММБИ КНЦ РАН): Тез. докл. Междунар. науч. конф. (г. Мурманск, 1-3 апреля 2015 г.). - Апатиты: Изд-во КНЦ РАН, 2015. - С. 228-230.

1394. Усягина И.С., Касаткина Н.Е., Ильин Г.В. Техногенные радионуклиды в морской среде и элементах наземной экосистемы архипелага Земля Франца-Иосифа // Тр. Кольского науч. центра РАН. 2014. - Т. 4(23). - Сер. Океанология. - Вып. 2. - С. 102-112.

1395. Усягина И.С., Касаткина Н.Е., Ильин Г.В. Антропогенные радионуклиды в элементах морской и наземной сред архипелага Земля Франца-Иосифа, 2000-2010 гг. // Комплексные исследования природы Шпицбергена и прилегающего шельфа: Матер. Междунар. науч. конф. (Мурманск, 6-8 ноября 2014 г.). Вып. 12. - М.: ГЕОС, 2014. - С. 297-305.

1396. Усягина И.С., Касаткина Н.Е., Матишов Д.Г. Реконструкция потоков ${ }^{137} \mathrm{Cs}$ и ${ }^{90} \mathrm{Sr}$ в Баренцевом море // VII Съезд по радиационным исследованиям (радиобиология, радиоэкология, радиационная безопасность): Тез. докл., Москва, 21-24 октября 2014 г. - М.: Изд-во Рос. ун-та дружбы народов, 2014. - С. 348.

1397. Усягина И.С., Матишов Д.Г., Павельская Е.В. Миграции радионуклидов в Баренцевом море // Радіобіологічні та радіоекологічні аспекти чорнобильської катастрофи: Тез. доповідей Міжнар. конф., м. Славутич, 11-15 квітня 2011 року. - Славутич: Фітосоціоцентр, 2011. - C. 186.

1398. Фарион Д.А., Усягина И.С. Современное загрязнение техногенными радионуклидами макрофитов Баренцева моря [Электронный ресурс] // Наука и образование - 2013: Матер. Междунар. науч.-техн. конф., Мурманск, 4-11 марта 2013 г. - Электрон. текст. дан. (220 Мб). Мурманск: Изд-во Мурм. гос. техн. ун-та, 2013. - С. 288-290. 1 электрон. опт. диск (CD-ROM). - Систем. требования: PC не ниже класса Pentium II; $128 \mathrm{Mb}$ RAM; свободное место на HDD $130 \mathrm{Mb}$; дисковод CD-ROM 2-х и выше. - Загл. с экрана. - Электрон. текст подг. ФГБОУ ВПО «МГТУ». - № гос. регистрации 0321301202.

1399. Федеральные морские и приморские особо охраняемые природные территории / В.А. Спиридонов, Ю.В. Краснов, Н.Г. Николаева, М.В. Гаврило // Атлас биологического разнообразия морей и побережий российской Арктики. - М.: Изд. WWF России, 2011. - С. 48-49. 
1400. Шавыкин А.А., Соколова С.А., Ващченко П.С. Взвесь при гидротехнических работах на шельфе. І. Время существования и размеры зон распространения // Защита окружающей среды в нефтегазовом комплексе. - 2011. - № 2. - С. 8-12.

1401. Шавыкин А.А., Соколова С.А., Ващченко П.С. Взвесь при гидротехнических работах на шельфе. II. Оценка воздействия на биоту при расчете ущерба рыбным запасам // Защита окружающей среды в нефтегазовом комплексе. - 2011. - № 3. - С. 30-35.

1402. Artificial radionuclides in edible wild mushrooms and berries of the Murmansk Region / G.G. Matishov, N.E. Kasatkina, I.S. Usyagina, D.A. Farion // Doklady Earth Sci. - 2014. - Vol. 455, part 2. - P. 463-468.

1403. Assessment of ${ }^{137} \mathrm{Cs}$ and ${ }^{90} \mathrm{Sr}$ fluxes in the Barents Sea / G. Matishov, I. Usiagina, N. Kasatkina, G. Il'in // Geophysical Res. Abstr. 2014. - Vol. 16 (EGU General Assembly 2014). - P. EGU2014-12869.

1404. CEEPRA - Collaboration network on EuroArctic environmental radiation protection and research / M. Risto, K. Vaaramaa, N. Kasatkina, A. Nalbandyan, J. Paatero, K. Reinikainen, D. Solatie [Электронный pecypc] // Abstracts of Nordic Society for Radiation Protection (NSFS) Conference (Reykjavik, August 22-25, 2011). - Reykjavik, 2011. - P. 95. - URL: http://yourhost.is/images/stories/NSFS2011/abstracts.pdf

1405. CEEPRA - Collaboration network on EuroArctic environmental radiation protection and research / D. Solatie, N. Kasatkina, A. Nalbandyan, J. Paatero, K. Reinikainen, M. Nissi, K. Vaaramaa, A.P. Leppänen [Электронный pecypc] // ICRER $2014-3^{\text {rd }}$ International Conference on Radioecology and Environmental Radioactivity (7-12 September 2014, Barcelona, Spain). Barcelona, 2014. - Presentation code: OP-010. - URL: https://intranet. pacificomeetings.com/amsysweb/publicacionOnline.jsf?id=146

1406. CEEPRA - Collaboration network on EuroArctic environmental radiation protection and research: Final report / A.-P. Leppänen, T. Rasilainen, K. Vaaramaa, J. Ylipieti, N. Kasatkina, G. Matishov, I. Usiagina, J. Gwynn, M. Iospje, B. Møller, A. Nalbandyan, J. Paatero, J. Vira, M. Nissi, K. Reinikainen, J. Bartnicki, H. Klein. - Jyväskylä, Finland: Kopijyvä Oy, 2014. - 44 p.

1407. CEEPRA - Euroopan arktisten alueiden säteilysuojelun ja tutkimuksen yhteistyöverkosto: Loppuraportti / A.-P. Leppänen, T. Rasilainen, K. Vaaramaa, J. Ylipieti, N. Kasatkina, G. Matishov, I. Usiagina, J. Gwynn, M. Iospje, B. Møller, A. Nalbandyan, J. Paatero, J. Vira, M. Nissi, K. Reinikainen, J. Bartnicki, H. Klein. - Jyväskylä, Finland: Säteilyturvakeskus, Kopijyvä Oy, 2014. $-44 \mathrm{~s}$.

1408. CEEPRA - Ovttasbargofierpmádat EuroArctica birrasa suonjardorvvolašvuođas ja dutkamuš: Loahpparaporta / A.-P. Leppänen, T. Rasilainen, K. Vaaramaa, J. Ylipieti, N. Kasatkina, G. Matishov, 
I. Usiagina, J. Gwynn, M. Iospje, B. Møller, A. Nalbandyan, J. Paatero, J. Vira, M. Nissi, K. Reinikainen, J. Bartnicki, H. Klein. - Jyväskylä, Finland: Kopijyvä Oy, 2014. - 44 p.

1409. CEEPRA - Samarbeidsnettverket om euroarktisk strålevern og forskning: Sluttrapport / A.-P. Leppänen, T. Rasilainen, K. Vaaramaa, J. Ylipieti, N. Kasatkina, G. Matishov, I. Usiagina, J. Gwynn, M. Iospje, B. Møller, A. Nalbandyan, J. Paatero, J. Vira, M. Nissi, K. Reinikainen, J. Bartnicki, H. Klein. - Jyväskylä, Finland: Säteilyturvakeskus, Kopijyvä Oy, 2014. -44 p.

1410. Chemical pollutions in the tissues of White Sea belugas / A. Chernetsky, V. Krasnova, P. Samsonov, V. Svetochev, V. Belkovich // Abstract of $28^{\text {th }}$ Annual conference of the ECS (European Cetacean Society), 5-9 April 2014, Liege, Belgium. - Liege, 2014. - P. 120.

1411. Collaboration network on EuroArctic environmental radiation protection and research / D. Solatie, T. Rasilainen, A. Nalbandyan, N. Kasatkina, J. Paatero, K. Reinikainen // Euroopan arktisten alueiden säteilysuojelun ja-tutkimuksen yhteistyöverkosto. - Rovaniemi: STUK, 2013. - 19 p.

1412. Cross-Border assessment of environmental radioactivity in the Euro-Arctic region / A. Nalbandyan, J.P. Gwynn, I.M. Eikelmann, B. Møller, A. Leppänen, T. Rasilainen, N. Kasatkina, I. Usiagina [Электронный pecypc] // ICRER 2014 - $3^{\text {rd }}$ International Conference on Radioecology and Environmental Radioactivity (7-12 September 2014, Barcelona, Spain). Barcelona, 2014. - Presentation code: OP-111. - URL: https://intranet. pacificomeetings.com/amsysweb/publicacionOnline.jsf?id=146

1413. Il'in G.V., Usaygina I.S., Kasatkina N.E. Radioecological state of marine and land environments in the region of Guba Andreeva // Atomic Energy. - 2015. - Vol. 118, iss. 3. - P. 215-221.

1414. Impact assessment of the Fukushima nuclear power plant accidental emission on the Barents Sea ecosystem / G. Matishov, G. Ilyin, N. Kasatkina, I. Usiagina, E. Pavelskaya // Geophysical Res. Abstr. - 2013. Vol. 15 (EGU General Assembly 2014). - P. EGU2013-12163-3.

1415. Matishov G.G., Inzhebeikin Yu.I., Savitskii R.M. The environmental and biotic impact of the oil spill in Kerch Strait in November 2007 // Water Resources. - 2013. - Vol. 40, № 3. - P. 271-284.

1416. Matishov G.G., Usyagina I.S., Pol'shin V.V. Long-term dynamics of Sea of Azov contamination withj the ${ }^{137}$ Cs isotope (19662013) // Doklady Earth Sci. - 2015. - Vol. 460, № 2. - P. 198-202.

1417. New data on the concentration of plutonium isotopes in the sediments of the Barents Sea / G.G. Matishov, N.E. Kasatkina, A-P. Leppanen, D.G. Matishov, D. Solatie // Doklady Earth Sci. - 2011. - Vol. 440, part 2. P. 1445-1448. 
1418. Quality assurance in cross-border monitoring of environmental radioactivity in the Euro-Arctic region / A. Nalbandyan, J.P. Gwynn, B. Møller, J. Nilssen, A-P. Leppänen, T. Rasilainen, N. Kasatkina, I. Usiagina // Fourth european IRPA congress radiation protection culture - a global challenge (June 23-27, 2014, Geneva, Switzerland): Abstr. book. - Geneva, 2014. - P. 170.

1419. Persistent organic pollutants in ringed seals from the Russian Arctic / V. Savinov, D.C. Muir, V. Svetochev, O. Svetocheva, S. Belikov, A. Boltunov, L. Alekseeva, L.-O. Reiersenf, T. Savinova // Sci. Total Environment. - 2011. - Vol. 409, iss. 14. - P. 2734-2745.

1420. Radioecological studies in the Barents Sea (results of expedition in 2007-2009) / A. Leppänen, N. Kasatkina, G. Matishov, D. Solatie [Электронный ресурс] // Third European IRPA Congress «Radiation protection - science, safety and security» (Helsinki, Finland, 14-18 June 2010). - Helsinki: Publ. STUK - Radiation and Nuclear Safety Authority, Finland, 2010. - P. 2550-2554. - URL: http://www.irpa2010europe.com

1421. Regularities of long-term changes in artificial radionuclides content in the Barents Sea ecosystem / G. Matishov, D. Matishov, D. Solatie, N. Kasatkina, A. Leppänen [Электронный pecypc] // Third European IRPA Congress «Radiation protection - science, safety and security» (Helsinki, Finland, 14-18 June 2010). - Helsinki: Publ. STUK - Radiation and Nuclear Safety Authority, Finland. - P. 2337-2344. - URL: http://www.irpa2010europe.com

1422. Selected anthropogenic and natural radioisotopes in the Barents Sea and off the western coast of Svalbard / A.-P. Leppänen, N. Kasatkina, K. Vaaramaa, G.G. Matishov, D. Solatie // J. Environmental Radioactivity. 2013. - Vol. 126. - P. 196-208.

1423. Toward the new role of marine and coastal protected areas in the Arctic: The Russian Case / V. Spiridonov, M. Gavrilo, Yu. Krasnov, A. Makarov, N. Nikolaeva, L. Sergienko, A. Popov, E. Krasnova // Protection of the Three Poles. - Part V. - Tokyo: Springer, 2012. - P. 171-202. - Doi: 10.1007/978-4-431-54006-9_8. - URL: http://www.springerlink.com/content/ $1161950548110512 /$

\section{ОЦЕНКА ВОЗДЕЙСТВИЯ НА ОКРУЖАЮЩУЮ СРЕДУ ПРИ ОСВОЕНИИ НЕФТЕГАЗОВЫХ МЕСТОРОЖДЕНИЙ}

1424. Веденев А.И., Авилов К.В., Шавыкин А.А. Оценка шумов рыболовства и зон акустического воздействия на морских млекопитающих при строительстве объектов нефтегазового комплекса в Баренцевом море // Морские млекопитающие Голарктики 2012: Сб. науч. труд. по матер. VII междунар. конф. (г. Суздаль, 24-28 сентября 2012 г.). - М.: РОО «Совет по морским млекопитающим», 2012. - С. 137-142. 
1425. Калинка О.П., Ващзенко П.С., Карнатов А.Н. Оценка уязвимости окружающей среды северо-западного сектора Арктики от прогнозируемых воздействий // Материалы XXX юбилейной конференции молодых ученых Мурманского морского биологического института, посвященной 150 -летию со дня рождения Н.М. Книповича, «Проблемы океанографии, биологии и освоения биоресурсов морей российской Арктики» (г. Мурманск, май 2012). - Мурманск: Изд. ММБИ КНЦ РАН, 2012. - С. 72-79.

1426. Калинка О.П., Карнатов А.Н., Ващенко П.С. Разработка карт экологической уязвимости прибрежных и морских зон арктических морей от нефти на примере Кольского залива // Арктическое морское природопользование в XXI веке - современный баланс научных традиций и инноваций (к 80-летию ММБИ КНЦ РАН): Тез. докл. Междунар. науч. конф. (г. Мурманск, 1-3 апреля 2015 г.). - Апатиты: Изд-во КНЦ РАН, 2015. - С. 95-97.

1427. Макаревич П.Р. Воздействие разработки объектов морского нефтегазового комплекса на пелагические фитоценозы Баренцева моря // Вестн. Мурм. гос. техн. ун-та. - 2013. - Т. 16, № 3. - С. 478-485.

1428. Методика построения карт интегральной уязвимости прибрежных и морских зон от нефти / А.А. Шавыкин, П.С. Ващенко, О.П. Калинка, А.Н. Карнатов [Электронный ресурс] // Веб-сайт «Центр компетенции по ликвидации разливов нефти в Арктике». - 2014. - URL: http:// www. osr-arctic.ru/ru/karty/metodika-postroeniya-kart-integralnoy-uyazvimostipribrezhnyh-i-morskih-zon-ot-nefti

1429. Методические подходы к созданию карт экологически уязвимых зон и районов приоритетной защиты акваторий и берегов Российской Федерации от разливов нефти и нефтепродуктов / В.Б. Погребов, А.А. Шавыкин, О.П. Калинка, М.Б. Шилин, М.В. Гаврило, Я.Ю. Блиновскал, А.Ю. Книжсников, М.А. Пухова. - Мурманск: Изд. WWF России, 2011. 55 c. - URL: http://www.wwf.ru/resources/publ/book/478

1430. Обобщенная схема алгоритма методики разработки карт уязвимости прибрежных и морских зон от нефти при ее разливе / А.А. Шавыкин, П.С. Ващенко, О.П. Калинка, А.Н. Карнатов [Электронный pecypc] // Веб-сайт «Центр компетенции по ликвидации разливов нефти в Арктике». - 2014. - URL: http://www.osr-arctic.ru/ru/karty/obobshchyonnayashema-algoritma-metodiki-razrabotki-kart-uyazvimosti-pribrezhnyh-i-morskih-zon

1431. Риски реализации проектов геологоразведки и нефтедобычи в условиях сероводородной зоны Черного моря / Г.Г. Матишов, Д.Г. Матишов, С.В. Бердников, Г.В. Ковалева, А.Д. Викришук // Вестн. Южного науч. центра РАН. - 2011. - Т. 7, № 1. - С. 59-64.

1432. Светочева О.Н., Светочев В.Н. О воздействиях и рисках для морских млекопитающих при разведке и добыче углеводородов в северных морях // Программа и материалы Международной научной 
конференции, посвященной 50-летию Зоологического музея им. М.И. Глобенко Таврической академии Крымского федерального университета им. В.И. Вернадского (Симферополь, 16-18 сентября 2015 г.). - Симферополь: Изд. Крым. фед. ун-та, 2015. - С. 105-107.

1433. Шавыкин A.A. Разработка карт экологической уязвимости от нефти прибрежно-морских зон арктических морей // ЭкоПечора 2015. Экосистемный подход природопользования в Арктике: преимущества и перспективы: Матер. Междунар. науч.-практ. конф., г. Нарьян-Мар, 17-18 октября 2014 г. - Нарьян-Мар: Красный город, 2014. - С. 57-66.

1434. Шавыкин A.A. Методика построения карт уязвимости прибрежных и морских зон от нефти // Арктическое морское природопользование в XXI веке - современный баланс научных традиций и инноваций (к 80-летию ММБИ КНЦ РАН): Тез. докл. Междунар. науч. конф. (г. Мурманск, 1-3 апреля 2015 г.). - Апатиты: Изд-во КНЦ РАН, 2015. - С. 250-253.

1435. Шавыкин A.A. Методика построения карт уязвимости прибрежных и морских зон от нефти. Пример карт для Кольского залива // Вестн. Кольского науч. центра РАН. - 2015. - № 2(21). C. 113-123.

1436. Шавыкин А.А. Эколого-океанографическое сопровождение освоения нефтегазовых месторождений Арктического шельфа (на примере Баренцева моря): Автореф. дис. ... докт. геогр. наук (25.00.28 океанология). - Мурманск, 2015. - 46 с.

1437. Шавыкин А.А., Малавенда С.В. Уязвимость макрофитобентоса Кольского залива от разливов нефти // Защита окружающей среды в нефтегазовом комплексе. - 2015. - № 10. - С. 12-18.

1438. Mapping water area vulnerability for oil spill contingency, response and other natural protection purposes: MMBI's methodology / A.A. Shavykin, P.S. Vashchenko, O.P. Kalinka, A.N. Karnatov // Kortrapport/ Brief report series. assessing vulnerability of flora and fauna in polar areas: Symp. proc. (November 3-4, 2014, Fram Centre, Tromsø, Norway). Tromsø: Norwegian Polar Institute, 2015. - P. 68-75.

1439. MMBI's methodology of coastline sensitivity and water area vulnerability mapping for oil contingency, response and other natural protection purposes / A.A. Shavykin, P.S. Vashchenko, O.P. Kalinka, A.N. Karnatov // Assessing vulnerability of flora and fauna in polar areas: Symp. proc. (November 3-4, 2014, Fram Centre, Tromsø, Norway. Tromsø: Norwegian Polar Institute, 2014. - P. 14.

1440. Voskoboinikov G., Makarov M., Rizhik I. Algae and oil: from visual observation to sanitary algae plantation // World Conference on Marine Biodiversity, 12-16 October 2014, Qingdao, China: Abstr. book. - Qingdao, 2014. - P. 217. 


\section{УСТОЙЧИВОЕ РАЗВИТИЕ ПРИБРЕЖНЫХ ЭКОСИСТЕМ И ЭКОЛОГИЧЕСКАЯ БЕЗОПАСНОСТЬ}

1441. Балыкин П.А., Кушнаренко А.И., Жичкин А.П. Водные биоресурсы России - использование и потенциал // Использование и охрана природных ресурсов в России. - 2012. - № 5. - С. 44-48.

1442. Берестовский Е.Г. Индустриальное вторжение садкового лосося в нативные популяции Salmo salar // Арктическое морское природопользование в XXI веке - современный баланс научных традиций и инноваций (к 80-летию ММБИ КНЦ РАН): Тез. докл. Междунар. науч. конф. (г. Мурманск, 1-3 апреля 2015 г.). - Апатиты: Изд-во КНЦ РАН, 2015. - С. 19-21.

1443. Васильев A.М., Денисов В.В. Проблемы и перспективы комплексного подхода к организации морской деятельности в прибрежноморском пространстве Мурманской области // Север и рынок: формирование экономического порядка. - 2012. - Т. 3, № 31. - С. 37-46.

1444. Васильев А.М., Денисов В.В. Проблемы и перспективы комплексного подхода к организации морской деятельности в прибрежноморском пространстве Мурманской области // Национальные интересы: приоритеты и безопасность. - 2012. - № 24(165). - С. 2-10.

1445. Ващенко П.С. Разработка карт чувствительности береговой линии арктических морей: необходимость, опыт построения, проблемы // Арктическое морское природопользование в XXI веке - современный баланс научных традиций и инноваций (к 80-летию ММБИ КНЦ РАН): Тез. докл. Междунар. науч. конф. (г. Мурманск, 1-3 апреля 2015 г.). Апатиты: Изд-во КНЦ РАН, 2015. - С. 28-30.

1446. Ващзенко П.С., Калинка О.П. Применение ГИС-технологий для оценки чувствительности побережья Кольского залива к разливам нефти // Вестн. Мурм. гос. техн. ун-та. - 2013. - Т. 16, № 3. - С. 542-549.

1447. Ващенко П.С., Шавыкин А.А. Разномасштабные ESI-карты чувствительности береговой линии Кольского залива к нефти // Освоение ресурсов нефти и газа российского шельфа: Арктика и Дальний Восток (ROOGD-2014): Тез. докл. V Междунар. конф., 29-30 октября 2014 г. М.: Газпром ВНИИГАЗ, 2014. - C. 96.

1448. Двореикий А.Г. О проведении судебных биологических экспертиз по камчатскому крабу (на примере Баренцева моря) // Вопросы рыболовства. - 2011. - Т. 12, № 1(45). - С. 175-181.

1449. Дворецкий А.Г. К методике расчета ущерба от нелегального вылова камчатского краба Баренцева моря // Рыбное хозяйство. - 2014. № 4. - С. 64-68. 
1450. Двореикий А.Г., Двореикий В.Г. Методика проведения экспертиз по камчатскому крабу Баренцева моря // Материалы VIII Всероссийской научной конференции по промысловым беспозвоночным (2-5 сентября 2015 г., г. Калининград). - Калининград: Изд-во Калинингр. гос. техн. ун-та, 2015. - С. 27-28.

1451. Денисов В.В. Развитие идей профессора А.П. Алхименко в области морского природопользования и экологической географии шельфовых морей // Морская геополитика в контексте XXI века. СПб.: ИПК «Прикладная экология», Комис. океана Рус. геогр. общ-ва, 2013. - C. $118-129$.

1452. Денисов В.В. Управление морскими биологическими ресурсами в Северо-Европейском бассейне на основе экосистемно-ориентированного подхода: состояние и перспективы // Национальные интересы России и экономика морских коммуникаций в Арктике: Матер. V Bcepoc. мор. науч.-практ. конф., 29-30 мая 2014 г. - Мурманск: Изд-во Мурм. гос. техн. ун-та, 2014. - С. 149-151.

1453. Денисов В.В., Васильев А.М. Проблемы и перспективы комплексного подхода к организации морской деятельности в прибрежноморском пространстве Мурманской области (на примере рыбного хозяйства) // Север и Арктика в новой парадигме мирового развития. Лузинские чтения - 2012: Тез. докл. VI Междунар. науч.-практ. конф., 12-14 апреля 2012 г., Апатиты. - Апатиты: Изд-во КНЦ РАН, 2012. C. 29-31.

1454. Денисов В.В., Жичкин А.П. Прибрежное рыболовство и аквакультура в Норвегии и России: сравнительный анализ экологогеографической ситуации на региональном уровне // Рыбное хозяйство. 2013. - № 6. - C. 22-26.

1455. Денисов В.В., Михайличенко Ю.Г. О роли региональных органов власти в управлении прибрежно-морскими акваториями России // Стратегическое планирование в регионах и городах России: выстраивая систему: Докл. участников XII Общерос. форума лидеров стратегического планирования, Санкт-Петербург, 21-23 октября 2013 г. - СПб.: Леонтьевский центр, 2014. - С. 90-92.

1456. Денисов В.В., Светлова М.В. Эколого-географическое положение Мурманской области // Учен. зап. Рос. гос. гидромет. ун-та. 2011. - № 20. - С. 187-193.

1457. Денисов В.В., Светлова М.B. Применение SWOT-анализа в исследовании эколого-географического положения региона (на примере Мурманской области) // Учен. зап. Рос. гос. гидромет. ун-та. - 2012. № 24. - С. 126-136. 
1458. Денисов В.В., Фомин С.Ю. Роль пространственного морского планирования в оценке влияния антропогенной деятельности при эксплуатации природных ресурсов и охране морских арктических территорий в связи с климатическими изменениями // Глобальные климатические процессы и их влияние на экосистемы арктических и субарктических регионов: Тез. докл. Междунар. науч. конф. (г. Мурманск, 9-11 ноября 2011 г.). - Апатиты: Изд-во КНЦ РАН, 2011. - С. 207-209.

1459. Денисов В.В., Жичкин А.П., Васильев А.М. Морское пространственное планирование в арктических и субарктических регионах РФ: проблемы реализации (на примере Мурманской области) // Север и рынок: формирование экономического порядка. - 2014. - № 3(40). C. $18-21$.

1460. Денисов В.В., Жичкин А.П., Ильин Г.В. Арктические архипелаги Баренцева экорегиона как объекты рационального природопользования и управления // Вестн. Мурм. гос. техн. ун-та. - 2012. - Т. 15, № 4. С. 733-738.

1461. Дженюк С.Л. Природные риски, сопутствующие морской деятельности на Баренцевом и Белом морях, и возможности их количественной оценки // Глобальные климатические процессы и их влияние на экосистемы арктических и субарктических регионов: Тез. докл. Междунар. науч. конф. (г. Мурманск, 9-11 ноября 2011 г.). Апатиты: Изд-во КНЦ РАН, 2011. - С. 49-51.

1462. Дженюк С.Л. Комплексное использование тематических данных для описания больших морских экосистем // Комплексные исследования больших морских экосистем России. - Апатиты: Изд-во КНЦ РАН, 2011. - С. 51-62.

1463. Дженюк С.Л. Информационные аспекты морского природопользования на арктическом шельфе России // Вестн. Южного науч. центра РАН. - 2014. - Т. 10, № 2. - С. 34-43.

1464. Дженюк С.Л., Матишова Е.С. Рекреационные ресурсы // Богатства России. - М.: Календа, 2012. - С. 224-229.

1465. Дженюк С.Л., Матишов Г.Г. Проблемы управления морским природопользованием и обеспечения экологической безопасности // Геоэкономические процессы в Арктике и развитие морских коммуникаций. - Апатиты: Изд-во КНЦ РАН, 2014. - С. 138-145.

1466. Жичкин А.П. Динамика климатических колебаний и миграции промысловых скоплений рыб в Баренцевом море // Глобальные климатические процессы и их влияние на экосистемы арктических и субарктических регионов: Тез. докл. Междунар. науч. конф. (г. Мурманск, 9-11 ноября 2011 г.). - Апатиты: Изд-во КНЦ РАН, 2011. - С. 63-65. 
1467. Жичкин А.П. Влияние природных и антропогенных факторов на рыбопромысловую деятельность в Баренцевом море // Стратегия морской деятельности России и экономика природопользования в Арктике: Матер. IV Bсерос. мор. науч.-практ. конф., Мурманск, 7-8 июня 2012 г. Мурманск: Изд-во Мурм. гос. техн. ун-та, 2012. - С. 127-129.

1468. Жичкин А.П. Межгодовые колебания промысловой значимости основных районов рыбного лова в экосистеме Баренцева моря // Национальные интересы России и экономика морских коммуникаций в Арктике: Матер. V Bсерос. мор. науч.-практ. конф., 29-30 мая 2014 г. Мурманск: Изд-во Мурм. гос. техн. ун-та, 2014. - С. 151-153.

1469. Жичкин А.П. Многолетняя изменчивость промысловой значимости различных районов промышленного рыболовства в Баренцевом море // Рыбное хозяйство. - 2014. - № 4. - С. 59-63.

1470. Жичкин А.П. Пространственно-временная изменчивость промысловой значимости различных районов рыбного лова в Баренцевом море // Вестн. Мурм. гос. техн. ун-та. - 2014. - Т. 17, № 3. - С. 465-473.

1471. Кавцевич Н.Н., Войнов В.Б. Биотехнические системы: назначение и структура // Морские животные на службе человеку: Матер. науч.-практ. семинара (4 октября 2010 г., Североморск). - Ростов н/Д.: Изд-во ЮНЦ РАН, 2011. - С. 17-24.

1472. Каленченко М.М. Природоохранная деятельность // Богатства России. - М.: Календа, 2012. - С. 230-235.

1473. Калинка О.П. Предложения к единой методике картирования уязвимости морских акваторий и побережий для планов ЛРН // Материалы XXIX конференции молодых ученых Мурманского морского биологического института, посвященной 140 -летию со дня рождения Г.А. Клюге, «Морские исследования экосистем европейской Арктики» (г. Мурманск, май 2011 г.). - Мурманск: Изд. ММБИ КНЦ РАН, 2011. С. 95-101.

1474. Калинка О.П. Оценка уязвимости морских экосистем от нефтяного загрязнения на примере Кольского залива // Фундаментальная и прикладная наука глазами молодых ученых. Успехи, перспективы, проблемы и пути их решения: Матер. IV науч.-практ. конф. молодых ученых РАН (г. Санкт-Петербург, 15-17 октября 2014 г.). - СПб.: Лема, 2014. - С. 18-20.

1475. Калинка О.П., Карнатов А.Н., Ващченко П.С. Карты экологической уязвимости Белого моря к нефтяному загрязнению // 2013 год - год охраны окружающей среды в России: Тез. докл. конф. молодых ученых (Мурманск, 12-13 февраля 2013 г.). - Мурманск: Изд-во Мурм. гос. техн. ун-та, 2013. - С. 85-89.

1476. Калинка О.П., Карнатов А.Н., Ващченко П.С. Оценка экологической уязвимости к нефтяному загрязнению на примере Белого 
моря // Проблемы изучения, рационального использования и охраны природных ресурсов Белого моря: Матер. XII Междунар. конф. с элементами школы для молодых ученых и аспирантов (Петрозаводск, 30 сентября-4 октября 2013 г.). - Петрозаводск: Изд-во КарелНЦ РАН, 2013. - C. 139-143.

1477. Калинка О.П., Карнатов А.Н., Ващенко П.С. Карты уязвимости акватории и прибрежной зоны Кольского залива для планов ликвидации разливов нефти // Материалы XXXI конференции молодых ученых Мурманского морского биологического института, посвященной 135-летию со дня рождения К.М. Дерюгина, «Океанография и биология арктических морей» (г. Мурманск, май 2013). - Мурманск: Изд. ММБИ КНЦ РАН, 2013. - С. 102-108.

1478. Калинка О.П., Шавыкин А.А., Ващенко П.С. Разномасштабные сезонные карты уязвимости акватории Кольского залива от нефти // Освоение ресурсов нефти и газа российского шельфа: Арктика и Дальний Восток (ROOGD-2014): Тез. докл. V Междунар. конф. 29-30 октября 2014 г. - М.: Газпром ВНИИГАЗ, 2014. - С. 95.

1479. Лебедева Н.В., Ломадзе Н.Х., Коломейцев С.Г. Функционирование зон покоя и эксплуатируемых охотничьих территорий на Веселовском водохранилище. - Ростов-н/Д.: Изд. Ростовского ГООХ, 2015. - 96 с.

1480. Матишов Г.Г. Природно-ресурсный потенциал России и его мировое значение // Богатства России. - М.: ООО Календа, 2012. C. $168-179$.

1481. Матишов Г.Г. Керченский пролив и дельта Дона: безопасность коммуникаций и населения // Вестн. Южного науч. центра РАН. 2015. - T. 11, № 1. - С. 6-15.

1482. Матишов Г.Г., Голубева Н.И. Значение аридных и семиаридных зон в системе природопользования России // Современное состояние и технологии мониторинга аридных и семиаридных экосистем юга России. - Ростов н/Д: Изд-во ЮНЦ РАН, 2010. - С. 11-18.

1483. Матишов Г.Г., Дженюк С.Л. Морская хозяйственная деятельность в российской Арктике в условиях современных климатических изменений // Арктика: экология и экономика. - 2012. - № 1(5). - С. 26-37.

1484. Матишов Г.Г., Дженюк С.Л. Задачи научного обеспечения морской деятельности в зоне Северного морского пути // Арктика. Экология и экономика. - 2014. - № 1(13). - С. 48-56.

1485. Матишов Г.Г., Дженюк С.Л. Проблемы управления морским природопользованием и обеспечения экологической безопасности в российской Арктике // Вестн. Мурм. гос. техн. ун-та. - 2014. - Т. 17, № 3. - С. 531-539. 
1486. Матишов Г.Г., Дженюк С.Л. Проблемы управления морским природопользованием и обеспечения экологической безопасности в российской Артике // Национальные интересы России и экономика морских коммуникаций в Арктике: Матер. V Bcерос. мор. науч.-практ. конф., 29-30 мая 2014 г. - Мурманск: Изд-во Мурм. гос. техн. ун-та, 2014. - C. $30-32$.

1487. Матишов Г.Г., Матишов Д.Г. Современные природные и социальные риски в Азово-Черноморском регионе // Вестн. РАН. 2013. - T. 83, № 12. - С. 1059-1067.

1488. Матишов Г.Г., Денисов В.В., Дженюк С.Л. Методические основы и результаты делимитации больших морских экосистем России // Комплексные исследования больших морских экосистем России. Апатиты: Изд-во КНЦ РАН, 2011. - С. 15-32.

1489. Матишов Г.Г., Денисов В.В., Жичкин А.П. Морское природопользование в западном секторе Арктики: проблемы и решения // Вестн. Кольского науч. центра РАН. - 2015. - № 2(21). - С. 103-112.

1490. Матишов Г.Г., Денисов В.В., Ильин Г.В. Управление морским природопользованием на основе экосистемных принципов // Комплексные исследования больших морских экосистем России. Апатиты: Изд-во КНЦ РАН, 2011. - С. 33-51.

1491. Международно-правовая квалификация морских районов в качестве исторических вод (теория и практика государств) / А.Н. Вылегжанин, Г.Г. Матишов, Б.А. Моргунов, Е.Л. Соколова. - М.: МГИМО-Университет, 2012. - 112 с.

1492. Моисеев Д.В. Радиационная безопасность под контролем // Российские полярные исследования. - 2011. - № 4(6). - С. 32.

1493. О возможной роли Fucus vesiculosus в очистке прибрежных акваторий от нефтяного загрязнения / Г.М. Воскобойников, Д.В. Пуговкин, B.B. Ильинский, E.Ю. Зубова // Изучение и освоение морских и наземных экосистем в условиях арктического и аридного климата: Матер. Междунар. науч. конф. (6-11 июня 2011 г., Ростов-на-Дону). - Ростов н/Д.: Изд-во ЮНЦ РАН, 2011. - С. 32-35.

1494. «Относительная» интегральная уязвимость акватории Кольского залива от нефти / А.А. Шавылкин, П.С. Ващенко, О.П. Калинка, А.Н. Карнатов [Электронный ресурс] // Веб-сайт «Центр компетенции по ликвидации разливов нефти в Арктике». - 2014. - URL: http://osr-arctic.ru/ru/karty/ otnositelnaya-integralnaya-uyazvimost-akvatorii-kolskogo-zaliva-ot-nefti

1495. Развитие арктического морского природопользования в ММБИ: теоретические и практические аспекты комплексного подхода на современном этапе (результаты и проблемы) / Г.Г. Матишов, В.В. Денисов, С.Л. Дженюк, 
А.П. Жичкин, Г.В. Ильин // Арктическое морское природопользование в XXI веке - современный баланс научных традиций и инноваций (к 80летию ММБИ КНЦ РАН): Тез. докл. Междунар. науч. конф. (г. Мурманск, 1-3 апреля 2015 г.). - Апатиты: Изд-во КНЦ РАН, 2015. - С. 156-158.

1496. Расчет и построение карт уязвимости Кольского залива от нефтяного загрязнения / О.П. Калинка, А.Н. Карнатов, П.С. Ващенко, A.А. Шавыкин // Современные эколого-биологические и химические исследования, техника и технология производств: Матер. Междунар. науч.-практ. конф., Мурманск, 7 апреля 2015 г.: В 2-х ч. - Мурманск: Изд-во Мурм. гос. техн. ун-та, 2015. - Ч. 1. - С. 117-119.

1497. Результаты натурализации искусственно выращенной кряквы и поддержание охотничьего ресурса / Н.В. Лебедева, Н.Х. Ломадзе, С.Г. Коломейцев, В.В. Куликов // Сохранение разнообразия животных и охотничье хозяйство России: 5-я Междунар. науч.-практ. конф. (г. Москва, 14-15 февраля 2013 г.). - М.: Изд-во РГАУ-МСХА им. К.А. Тимирязева, 2013. - С. 451-453.

1498. Санитарная водорослевая плантация (СВП): Варианты / Г.М. Воскобойников, Е.Ю. Зубова, М.В. Макаров, Д.В. Пуговкин, И.В. Рыжик // Биоразнообразие и устойчивое развитие: Матер. докл. III Междунар. науч.-практ. конф. (Симферополь, 15-19 сентября 2014 г.). - Симферополь: Изд-во Крым. науч. центра, 2014. - С. 66.

1499. Светочев В.Н. Дождались? Возобновится ли промысел гренландского тюленя в Белом море [Электронный ресурс] // Природно-ресурсные ведомости. - 2015. - № 1-2. - C. 1-2. - URL: http://www.priroda.ru/reviews/detail.php?ID=10983

1500. Троценко А.А., Будилова Е.В., Журавлева Н.Г. Методика оценки экологического состояния городской среды на основе характеристик неспецифической резистентности организма человека [Электронный ресурс] // Руководство по изучению городской среды. Экологические и социально-психологические аспекты / Науч. ред. проф. Д.Н. Кавтарадзе. - М.: МГУ, 2015 - 1 электрон. опт. диск (CD-ROM). URL: http://istina.msu.ru/publications/article/11122180/

1501. Управление водоплавающими птицами в Ростовском государственном опытном охотничьем хозяйстве / С.Г. Коломийцев, В.В. Куликов, Н.Х. Ломадзе, В.Н. Говорунов, Н.В. Лебедева // Тр. Ростов. гос. опытно-охотничьего хоз-ва. - 2012. - Вып. 2 - 208 с.

1502. Устойчивое развитие морского сегмента БЕАР (приоритеты, реалии, компромиссы) / Г.Г. Матишов, В.В. Денисов, А.П. Жичкин, Д.В. Моисеев // Арктика: экология и экономика. - 2013. - № 1(9). C. 60-69. 
1503. Учет вековой динамики климата Баренцева моря при планировании морской деятельности / Г.Г. Матишов, П.Р. Макаревич, В.В. Денисов, С.Л. Дженюк, А.П. Жичкин, Д.В. Моисеев // Стратегия морской деятельности России и экономика природопользования в Арктике: Матер. IV Всерос. мор. науч.-практ. конф., Мурманск, 7-8 июня 2012 г. Мурманск: Изд-во Мурм. гос. техн. ун-та, 2012. - С. 17-22.

1504. Чувствительность береговой линии Кольского залива к разливам нефти по индексу ESI / А.А. Шавыкин, П.С. Ващенко, О.П. Калинка, A.Н. Карнатов [Электронный ресурс] // Веб-сайт «Центр компетенции по ликвидации разливов нефти в Арктике». - 2014. - URL: http://osrarctic.ru/ru/karty/chuvstvitelnost-beregovoy-linii-kolskogo-zaliva-k-razlivamnefti-po-indeksu-esi

1505. Фарион Д.А. Внутреннее облучение населения Мурманской области от цезия-137 и стронция-90 за счет потребления основных продуктов питания // 2013 год - год охраны окружающей среды в России: Тез. докл. конф. молодых ученых (Мурманск, 12-13 февраля 2013 г.). - Мурманск: Изд-во Мурм. гос. техн. ун-та, 2013. - С. 22-27.

1506. Фарион Д.А. Роль грибов в формировании дозы внутреннего облучения населения Мурманской области // Материалы XXXI конференции молодых ученых Мурманского морского биологического института, посвященной 135-летию со дня рождения К.М. Дерюгина, «Океанография и биология арктических морей» (г. Мурманск, май 2013 г.). - Мурманск: Изд. ММБИ КНЦ РАН, 2013. - С. 173-180.

1507. Фарион Д.А., Усягина И.С. Радиоактивное загрязнение элементов наземных экосистем Кольского полуострова // Материалы XXX юбилейной конференции молодых ученых Мурманского морского биологического института, посвященной 150 -летию со дня рождения Н.М. Книповича, «Проблемы океанографии, биологии и освоения биоресурсов морей российской Арктики» (г. Мурманск, май 2012 г.). Мурманск: Изд. ММБИ КНЦ РАН, 2012. - С. 169-173.

1508. Эколого-географические аспекты развития морской деятельности Мурманской области / Г.Г. Матишов, В.В. Денисов, С.Л. Дженюк, Г.В. Ильин // Живущие на Севере. - Мурманск: Изд-во Мурм. гос. гуман. ун-та, 2012. - Вып. 2. - С. 10-13 (+ вклейка на 8 с.).

1509. Vedenev A., Avilov K., Shavykin A. Assessment of zones of the acoustic impact on the arctic marine mammals at industrial activity in the Barents Sea // Information and Ideas Worth Sharing: Abstr. book on $26^{\text {th }}$ european cetacean society conf., 26-28 March, 2012. - Galway, Ireland, 2012. - P. 285. 


\section{ТЕХНОЛОГИЯ ПЕРЕРАБОТКИ ГИДРОБИОНТОВ И ВОДОРОСЛЕЙ}

1510. Влияние ультразвуковой обработки на химический состав и антикоагулянтные свойства сухого экстракта фукуса / Е.Д. Облучинская, М.Н. Макарова, О.Н. Пожарицкая, А.Н. Шиков // Хим.-фарм. журн. 2015. - T. 49. № 3. - С. 35-38.

1511. Клиндух М.П., Облучинская Е.Д. Экстракты фукусовых водорослей северных морей России как источник БАВ // Молодая наука Заполярья: Тез. докл. регион. молодежного форума. - Мурманск: Изд-во Мурм. гос. техн. ун-та, 2013. - С. 11-15.

1512. Клиндух М.П., Облучинская Е.Д. Исследование влияния концентрации спирта на содержание биологически активных веществ в настойках фукусовых водорослей // Здоровье. Медицинская экология. Наука. - 2014. - № 3(57). - С. 31-33. - URL: http://hmes-jornal.narod.ru/ current_issue 57.htm

1513. Клиндух М.П., Облучинская Е.Д. Этанольные экстракты фукусовых водорослей Баренцева моря // Современные проблемы экологии и природопользования: Матер. регион. науч.-практ. конф., посвященной 15-летию со дня основания кафедры биоэкологии, Мурманск, 27-28 февраля 2014 г. - Мурманск: Изд-во Мурм. гос. техн. ун-та, 2014. C. 230-235.

1514. Клиндух М.П., Облучинская Е.Д. Химический состав и антиоксидантная активность настоек фукусовых водорослей // Фармация. 2015. - № 3. - C. 8-11.

1515. Облучинская Е.Д. Технология и применение комплексных биотехнологических препаратов из фукусовых водорослей // Материалы VII Московского международного конгресса «Биотехнология: состояние и перспективы развития», г. Москва, 19-22 марта 2013 г. - М.: ЗАО «Экспобиохим-технологии»; РХТУ им. Д.И. Менделеева, 2013. - С. 271-272.

1516. Облучинская Е.Д. Биологически активные вещества бурых водорослей: состав и фармакологические свойства // Фармация. - 2014. № 4. - C. 49-51.

1517. Облучинская Е.Д. Новые комплексные биопрепараты из фукусовых водорослей // Современные проблемы экологии и природопользования: Матер. регион. науч.-практ. конф., посвященной 15-летию со дня основания кафедры биоэкологии, Мурманск, 27-28 февраля 2014 г. - Мурманск: Изд-во Мурм. гос. техн. ун-та, 2014. - С. 83-86.

1518. Облучинская Е.Д. Методические подходы к разработке биопрепаратов на основе фукусовых водорослей // Вестн. Кольского науч. центра РАН. - 2015. - № 2(21). - С. 78-81. 
1519. Облучинская Е.Д. Методологические подходы к разработке биопрепаратов на основе водорослей в свете концепции рационального природопользования // Современные эколого-биологические и химические исследования, техника и технология производств: Матер. Междунар. науч.-практ. конф., Мурманск, 7 апреля 2015 г.: В 2-х ч. - Мурманск: Изд-во Мурм. гос. техн. ун-та, 2015. - Ч. 1. - С. 243-246.

1520. Облучинская Е.Д. Содержание полифенолов водорослей Баренцева моря и их антиоксидантная активность // Арктическое морское природопользование в XXI веке - современный баланс научных традиций и инноваций (к 80-летию ММБИ КНЦ РАН): Тез. докл. Междунар. науч. конф. (г. Мурманск, 1-3 апреля 2015 г.). - Апатиты: Изд-во КНЦ РАН, 2015. - С. 178-179.

1521. Облучинская Е.Д. Теоретические и экспериментальные аспекты создания биопрепаратов на основе фукусовых водорослей // Здоровье. Медицинская экология. Наука. - 2015. - № 1(59). - С. 41-43.

1522. Облучинская Е.Д., Рыюсик И.В. Изучение слоевищ фукусовых водорослей // Фармация. - 2014. - № 2. - С. 19-21.

1523. Effects of ultrsound treatment on the chemical composition and anticoagulant properties of dry focus extract / E.D. Obluchinskaya, M.N. Makarova, O.N. Pozhariskaya, A.N. Shikov // Pharmaceutical Chemistry J. 2015. - Vol. 49, № 3. - P. 183-186.

1524. Lipid composition of brown algae species by HPTLC / E.D. Obluchinskaya, S.A. Ivanova, O.N. Pozharitskaya, A.N. Shikov // Reviews of clinical pharmacolgy and drug therapy. - 2013. Vol. 11 (suppl.). - P. 68.

1525. Obluchinskaya E.D. Biochemical and technological aspects of BAS of fucoids of the Barents Sea // Renewable wood and plant resources: chemistry, technology, pharmacology, medicine: Abstr. Intern. Conf. (SaintPetersburg, June 21-24 2011). - Saint-Petersburg: BBM, 2011. - P. 156-157.

1526. Obluchinskaya E.D. Physical and chemical properties, anticoagulant and antioxidant activity of fucus dry extract // Reviews of clinical pharmacolgy and drug therapy. - 2012. - Vol. 10. - № 2. - P. 85.

1527. Obluchinskaya E.D. New method obtain the fucoidan containing extracy with the ultrasonic treatment // Reviews of clinical pharmacolgy and drug therapy. 2013. Vol. 11 (suppl.). - P. 67-68.

1528. Obluchinskaya E.D. Comparative study of antioxidant activity of fucus ethanol extracts // Reviews of clinical pharmacolgy and drug therapy. - 2014. - Vol. 12 (suppl.) - P. 47-48.

1529. Obluchinskaya E.D. Effect of extrinsic factors on the polyphenol content of Fucus from the Barents Sea // Reviews of clinical pharmacolgy and drug therapy. - 2015. - Vol. 13 (suppl.) - P. 67. 


\section{МОНОГРАФИИ}

1530. Адров Н.M. Полярная наука Книповича (к 150-летию со дня его рождения). - Апатиты: Изд-во КНЦ РАН, 2012. - 253 с.

1531. Адров Н.М. Дерюгинские рубежи морской биологии (к 135летию со дня рождения К.М. Дерюгина). - Мурманск: Изд. ММБИ КНЦ РАН, 2013. - 164 c.

1532. Биоэкологические аспекты защитных реакций рыб и беспозвоночных / Н.Г. Журавлева, Г.Г. Матишов, О.Н. Оттесен, E.E. Минченок. - Апатиты: Изд-во КНЦ РАН, 2011. - 272 с.

1533. Биоэкологические основы жизнедеятельности организмов в условиях Заполярья / Н.Г. Журавлева, Г.Г. Матишов, О. Оттесен, E.В. Будилова, А.А. Троченко, Т.М. Ларина / Отв. ред. А.Д. Чинарина. Апатиты: Изд-во КНЦ РАН, 2013. - 210 с.

1534. Дворецккий А.Г., Двореикий В.Г. Эпифауна крабов-литодид в Баренцевом море / Отв. ред. П.Р. Макаревич. - Апатиты: Изд-во КНЦ PAH, 2012. $-410 \mathrm{c}$.

1535. Дворецккий В.Г., Дворецикий А.Г. Биология и роль Oithona similis в зоопланктоне морей Арктики / Отв. ред. П.Р. Макаревич. Апатиты: Изд-во КНЦ РАН, 2011. 149 с.

1536. Дворецкий В.Г., Дворецкий А.Г. Экология зоопланктонных сообществ Баренцева моря и сопредельных вод / Отв. ред. П.Р. Макаревич. СПб.: Реноме, 2015. - 736 с.

1537. Комплексные исследования больших морских экосистем России / Отв. ред. Г.Г. Матишов. - Апатиты: Изд-во КНЦ РАН, 2011. 516 с.

1538. Комплексные экосистемные исследования Арктики по трассе Северного морского пути на атомных ледоколах (20 лет опыта ММБИ) / Г.Г. Матишов, Ю.А. Баданин, А.А. Дерябин, С.Л. Дженюк, Д.Г. Иикулов, Д.В. Моисеев. - Ростов н/Д.: Изд-во ЮНЦ РАН, 2014. - 96 с.

1539. Макаревич П.Р., Водопьянова В.В., Олейник А.А. Фитоценозы пелагиали Кольского залива. Структура и функциональные характеристики / Отв. ред. С.Л. Дженюк. - Ростов н/Д.: Изд-во ЮНЦ РАН, 2015. - 192 с.

1540. Матишов Г.Г., Клещенков А.В. Кубанский паводковый кризис. Климат, геоморфология, прогноз. Крымск, июль 2012 г. Ростов н/Д.: Изд-во ЮНЦ РАН, 2012. - 128 с. 
1541. Матишов Г.Г., Войнов В.Б., Михайлюк А.Л. Руководство по подготовке морских млекопитающих в составе биотехнических систем в Арктике. - Ростов н/Д.: Изд-во ЮНЦ РАН, 2015. - 212 с.

1542. Матишов Г.Г., Горяев Ю.И., Иикулов Д.Г. Белый медведь Карского моря. Результаты экспедиционных работ ММБИ в районе прохождения трасс Севморпути в 1997-2013 гг. - Ростов н/Д.: Изд-во ЮНЦ РАН, 2013. - 112 c.

1543. Митяев M.B. Мурманское побережье (геологогеоморфологические и климатические особенности, современные геологические процессы) / Отв. ред. Л.Г. Павлова. - Апатиты: Изд-во КНЦ РАН, 2014. - 226 с.

1544. Морские экосистемы и сообщества в условиях современных климатических изменений / Отв. ред. Г.Г. Матишов. - СПб.: Реноме, 2014. $-456 \mathrm{c}$.

1545. Погодина И.А. Фораминиферы в донных отложениях морей Западной Арктики / Отв. ред. Г.А. Тарасов. - Апатиты: Изд-во КНЦ PAH, 2014. - 192 c.

1546. Практическая аквакультура (разработки ЮНЦ РАН и ММБИ КНЦ РАН) / Г.Г. Матишов, Е.Н. Пономарева, Н.Г. Журавлева, В.А. Григорьев, В.А. Лужняк. - Ростов н/Д.: Изд-во ЮНЦ РАН, 2011. - 282 с.

1547. Птицы северных и южных морей России: фауна, экология / Отв. ред. П.Р. Макаревич. - Апатиты: Изд-во КНЦ РАН, 2013. - 294 с.

1548. Селифонова Ж.П. Экосистемы акваторий черноморских портов Новороссийска и Туапсе / Под ред. Г.Г. Матишова. - СПб.: Наука, 2012. - 228 с.

1549. Селифонова Ж.П. Прибрежные экосистемы северо-восточного шельфа Черного моря и Азовского моря. - Новороссийск: ГМУ им. адм. Ф.Ф. Ушакова, 2014. - 170 с.

1550. Симбионты промысловых видов крабов Охотского и Баренцева морей / Г.Г. Матишов, И.В. Карманова, А.Г. Двореикий, С.Ю. Утевский / Отв. ред. Д.Г. Ишкулов. - Ростов н/Д.: Изд-во ЮНЦ РАН, 2014. - 276 с.

1551. Чинарина А.Д. «Смотреть вперед и помнить...». Очерки из истории ММБИ КНЦ РАН / Отв. ред. Е.Э. Кириллова. - Ростов н/Д.: Изд-во ЮНЦ РАН, 2012. - 326 с.

1552. Matishov G.G., Ognetov G.N. White whale (Delphinapterus leucas) of the Russia Arctic Seas: biology, ecology, protection and exploitation of resources / G. Matishov, M. Castellote, S.M. Gendron (Eds.). - Spain: Fundación Ciudad de las Artes y las Ciencias - Comunitat Valencuiana, 2011. - 302 c. 


\section{СБОРНИКИ СТАТЕЙ, ТРУДЫ, МАТЕРИАЛЫ КОНФЕРЕНЦИЙ}

1553. Арктическое морское природопользование в XXI веке современный баланс научных традиций и инноваций (к 80-летию ММБИ КНЦ РАН): Тез. докл. Междунар. науч. конф. (г. Мурманск, 1-3 апреля 2015 г.) / Отв. ред. Г.Г. Матишов. - Апатиты: Изд-во КНЦ PAH, 2015. -275 c.

1554. Биоресурсы и аквакультура: Тез. докл. Школы молодых ученых по морской биологии (Мурманск, 28-29 февраля 2012 г.) / Ред. С.А. Афончева, Е.В. Шошина. - Мурманск: Изд-во Мурм. гос. техн. ун-та, 2012. $-48 \mathrm{c}$.

1555. Глобальные климатические процессы и их влияние на экосистемы арктических и субарктических регионов: Тез. докл. Междунар. науч. конф. (г. Мурманск, 9-11 ноября 2011 г.) / Отв. ред. Г.Г. Матишов. - Апатиты: Изд-во КНЦ РАН, 2011. - 219 с.

1556. Естественно-научные проблемы Арктического региона: $\mathrm{X}$ региональная научная студенческая конференция, Мурманск, 14 мая 2010 г.: Тр. конф. / Отв. ред. О.Н. Богаевская, С.М. Черняков. Мурманск: Изд-во Мурм. гос. гуманитар. ун-та, 2011. - 109 с.

1557. Комплексные исследования природы Шпицбергена: Матер. Междунар. науч. конф. (Мурманск, 1-3 ноября 2012 г.). Вып. 11. - М.: ГЕОС, 2012. - $284 \mathrm{c}$.

1558. Комплексные исследования природы Шпицбергена и прилегающего шельфа: Матер. Междунар. науч. конф. (Мурманск, 6-8 ноября 2014 г.). Вып. 12. - М.: ГЕОС, 2014. - 378 с.

1559. Кулики Северной Евразии: экология, миграции и охрана: Матер. VIII Междунар. науч. конф. (10-12 ноября 2009 г., г. Ростов-на-Дону) / Отв. ред. Н.В.Лебедева.- Ростов н/Д.: Изд-во ЮНЦ РАН, 2011. - 308 с.

1560. Материалы XXIX конференции молодых ученых Мурманского морского биологического института, посвященной 140-летию со дня рождения Г.А. Клюге, «Морские исследования экосистем европейской Арктики» (г. Мурманск, май 2011 г.). - Мурманск: Изд. ММБИ КНЦ PAH, 2011. $-226 \mathrm{c}$.

1561. Материалы XXX юбилейной конференции молодых ученых Мурманского морского биологического института, посвященной 150-летию со дня рождения Н.М. Книповича, «Проблемы океанографии, биологии и освоения биоресурсов морей российской Арктики» (г. Мурманск, май 2012). - Мурманск: Изд. ММБИ КНЦ РАН, 2012. - 180 с. 
1562. Материалы XXXI конференции молодых ученых Мурманского морского биологического института, посвященной 135-летию со дня рождения К.М. Дерюгина, «Океанография и биология арктических морей» (г. Мурманск, май 2013). - Мурманск: Изд. ММБИ КНЦ РАН, 2013. - 200 с.

1563. Морские животные на службе человеку: Матер. науч.-практ. семинара (4 октября 2010 г., Североморск). - Ростов н/Д.: Изд-во ЮНЦ PAH, 2011. - $80 \mathrm{c}$.

1564. Проблемы Арктического региона: 11-я Международная научная конференция студентов и аспирантов, г. Мурманск, 12 мая 2011 г.: Тез. конф. / [Редкол.: С.М. Черняков и др.]. - Мурманск: Изд. ММБИ КНЦ PAH, 2011. $-93 \mathrm{c}$.

1565. Проблемы Арктического региона: Одиннадцатая Международная научная конференция студентов и аспирантов, Мурманск, 12 мая 2011 г.: Тр. конф. / [Редкол.: С.М. Черняков (науч. ред.) и др.]. - Мурманск: Изд. Мурм. гос. гуманитар. ун-та, 2012. - 95 с.

1566. Проблемы Арктического региона: 12-я Международная научная конференция студентов и аспирантов, г. Мурманск, май 2012 г.: Тез. конф. / [Редкол.: С.М. Черняков и др.]. - Мурманск: Изд. ММБИ КНЦ РАН, 2012. - 112 c.

1567. Проблемы Арктического региона: Двенадцатая Международная научная конференция студентов и аспирантов, Мурманск, 15 мая 2012 г.: Тр. конф. / [Редкол.: С.М. Черняков (науч. ред.) и др.]. - Мурманск: Изд. ММБИ КНЦ РАН, 2012. - 189 с.

1568. Проблемы Арктического региона: 13-я Международная научная конференция студентов и аспирантов, г. Мурманск, май 2013 г. / [Редкол.: С.М. Черняков, А.В. Дьяконова].: Тез. конф. - Мурманск: Изд. ММБИ КНЦ РАН, 2013. - 98 с.

1569. Проблемы Арктического региона: 13-я Международная научная конференция студентов и аспирантов, г. Мурманск, май 2013 г.: Тр. конф. / [Редкол.: С.М. Черняков, А.В. Дьяконова]. - Мурманск: Изд. ММБИ КНЦ РАН, 2014. - 161 с.

1570. Проблемы Арктического региона: Материалы XIV Международной научной конференции студентов и аспирантов (г. Мурманск, май 2014 г.). Т. II. Форум студентов и аспирантов / [Редкол.: С.М. Черняков и др.]. - Мурманск: Изд. ММБИ КНЦ РАН, 2014. -148 c.

1571. Проблемы Арктического региона: Труды XIV Международной научной конференции студентов и аспирантов (г. Мурманск, май 2014 г.) / [Редкол.: С.М. Черняков и др.]. - Мурманск: Изд. ММБИ КНЦ РАН, 2014. - 240 с. 
1572. Проблемы Арктического региона: Пятнадцатая Международная научная конференция студентов и аспирантов (г. Мурманск, 14 мая 2015 г.): Тез. докл. - Ростов н/Д.: Изд-во ЮНЦ РАН, 2015. - 164 с. (Электронное изд. в формате PDF).

1573. Теоретические аспекты колониальности у птиц / Отв. ред. Н.В. Лебедева. - Ростов н/Д.: Изд-во ЮНЦ РАН, 2012. - 270 с.

1574. Труды Кольского научного центра. - Т. 1(14). - Сер. Океанология. - Вып. 1. - 224 с.

1575. Труды Кольского научного центра. - Т. 4(23). - Сер. Океанология. - Вып. 2. - 299 с.

1576. Экология морских птиц Белого моря / Отв. ред. Г.Г. Матишов. Апатиты: Изд-во КНЦ РАН, 2012. - 181 с.

1577. Эколого-эволюционные исследования морских организмов и экосистем: Материалы XIV Международной научной конференции студентов и аспирантов «Проблемы Арктического региона» (г. Мурманск, май 2014 г.). Т. І. Форум молодых ученых, посвященный 110-летию со дня рождения Ю.И. Полянского (XXXII конференция молодыХ ученых ММБИ) / [Редкол.: С.М. Черняков и др.]. - Мурманск: Изд. ММБИ КНЦ РАН, 2014. - 162 с.

\section{УЧЕБНО-МЕТОДИЧЕСКИЕ ИЗДАНИЯ}

1578. Адров М.Н., Адров Н.М. Теоретические основы прогрессивных технологий высшего образования. - Мурманск: Изд-во Мурм. гос. техн. ун-та, 2011. - $168 \mathrm{c}$.

1579. Журавлева Н.Г. Ихтиология. Методические указания к самостоятельной работе студентов заочной формы обучения по специальности 020803.65 «Биоэкология». - Мурманск: Изд-во Мурм. гос. техн. ун-та. 2011. -35 с.

1580. Журавлева Н.Г. Экологическая эмбриология рыб. Методические указания к самостоятельной работе студентов специальности 020803.65 «Биоэкология» заочной формы обучения. - Мурманск: Изд-во Мурм. гос. техн. ун-та, 2011. -28 с.

1581. Журавлева Н.Г. Аквакультура и устойчивое развитие. Методические указания к самостоятельным занятиям и контрольной работе для студентов по направлению подготовки 022000.68 «Экология и рациональное природопользование». - Мурманск: Изд-во Мурм. гос. техн. ун-та, 2012. - 46 с. 
1582. Журавлева Н.Г. Экология и природопользование. Методические указания и программа научно-исследовательской и научно-педагогической практики по направлению подготовки 022000.68 «Экология и природопользование». - Мурманск: Изд-во Мурм. гос. техн. ун-та, 2014. - 195 с.

1583. Иллюстрированный атлас «Биоэкологические экскурсии»: Учебное пособие по дисциплине «Животный и растительный мир Мурманской области» для направления 020400.62 «Биология» (профиль «Биоэкология») / Н.А. Пахомова, Е.Е. Минченок, Н.А. Салмова, Н.Г. Журавлева. - Мурманск: Изд-во Мурм. гос. техн. ун-та, 2012. - 182 с.

1584. Ларина Т.М., Журавлева Н.Г. Экология человека. Методические указания к самостоятельным занятиям и контрольной работе для студентов по направлению подготовки 020400.62 «Биология». Мурманск: Изд-во Мурм. гос. техн. ун-та, 2012. - 32 с.

1585. Пахомова Н.А., Минченок Е.Е., Журавлева Н.Г. Программа научно-исследовательской и научно-педагогической практики по направлению подготовки 022000.68 «Экология и природопользование», профиль «Биоэкология»: учебно-методическая разработка. - Мурманск: Изд-во Мурм. гос. техн. ун-та, 2013.

1586. Пахомова Н.А., Минченок Е.Е., Журавлева Н.Г. Программа производственной практики по направлению подготовки 020400.62 «Биология», профиль «Биоэкология»: учебно-методическая разработка. Мурманск: Изд-во Мурм. гос. техн. ун-та, 2013.

1587. Пахомова Н.А., Минченок Е.Е., Журавлева Н.Г. Программа учебной практики по направлению подготовки 020400.62 «Биология», профиль «Биоэкология»: учебно-методическая разработка. - Мурманск: Изд-во Мурм. гос. техн. ун-та, 2013.

1588. Учебное пособие по дисциплине «Биоэкология» «Большой практикум» для направления 020200.62 «Биология» (профиль «Экология») и специальности 020803.65 «Биоэкология» / Е.Е. Минченок, Т.М. Ларина, Н.А. Пахомова, Н.Г. Журавлева. - Мурманск: Изд-во Мурм. гос. техн. ун-та, 2011. $-126 \mathrm{c}$.

1589. Учебное пособие по дисциплине «Животный и растительный мир Мурманской области» для направления 020400.62 «Биология» (профиль «Экология»). Иллюстрированный атлас «Зоологические и ботанические экскурсии» / Е.Е. Минченок, Н.А. Салмова, Н.А. Пахомова, Н.Г. Журавлева. - Мурманск: Изд-во Мурм. гос. техн. ун-та, 2012. - 142 с. 


\section{ИНФОРМАЦИОННЫЕ ИЗДАНИЯ}

1590. Библиографический указатель работ сотрудников Мурманского морского биологического института (2006-2010 гг.) / Отв. ред. акад. РАН Г.Г. Матишов. - Апатиты: Изд-во КНЦ РАН, 2012. - 256 с.

1591. Гаврилов В.М., Лебедева Н.В., Ильина Т.А. Международная научная конференция «Птицы-дуплогнездники как модельные объекты в решении проблем популяционной экологии и эволюции» // Зоол. журн. - 2015. - Т. 94, № 4. - С. 494-496.

1592. Дворецкий А.Г. Вклад ученых Мурманского морского биологического института в изучение камчатского краба Баренцева моря // Вестн. Кольского науч. центра РАН. - 2015. - № 2(21). - С. 33-39.

1593. Калинка О.П. Тридцатилетний опыт проведения конференций молодых ученых ММБИ // Фундаментальная и прикладная наука глазами молодых ученых. Успехи, перспективы, проблемы и пути их решения. II научно-практическая конференция молодых ученых РАН, г. Санкт Петербург, 28-30 мая 2012 г. - СПб.: Лема, 2012. - С. 49-50.

1594. Калинка О.П., Моисеев Д.В. Опыт работы СМУС Мурманской области в 2009-2013 гг. // Фундаментальная и прикладная наука глазами молодых ученых. Успехи, перспективы, проблемы и пути их решения, г. Санкт-Петербург, 5-7 июня 2013 г. III научно-практическая конференция молодых ученых РАН. - СПб.: Лема, 2013 - С. 67-69.

1595. Ларионов В.В., Горяев Ю.И., Иикулов Д.Г. Юбилейная экспедиция Мурманского морского биологического института по трассе Севморпути на а/л «Ямал» зимой 2011 г. // Российские полярные исследования. - 2012. - № 1(7). - С. 14-16.

1596. Лебедева Н.В. Международная научная конференция «Экология птиц: виды, сообщества, взаимосвязи» // Вестн. Южного науч. центра РАН. - 2012. - Т. 8, № 2. - С. 89-90.

1597. Лебедева Н.В. Юбилей рабочей группы по куликам // Информационные материалы Рабочей группы по куликам Северной Евразии. - М.: Изд. РГК, 2013. - № 26. - С. 82-85.

1598. Макаревич П.Р., Моисеев Д.В. Международный проект «GreenSeas» // Российские полярные исследования. - 2014. - № 3(17). C. 30-33.

1599. Матишов Г.Г. Перспективы научно-технического и гуманитарного развития южного макрорегиона // Вестн. Южного науч. центра РАН. - 2013. - Т. 9, № 4. - С. 3-12. 
1600. Матишов Г.Г., Миноранский В.А. 10 лет ассоциации «Живая природа степи» // Вестн. Южного науч. центра РАН. - 2015. - Т. 11, № 1. - С. 107-108.

1601. Матишов Г.Г., Павленко А.А., Григорьев В.А. Опыт организации малого инновационного предприятия «ИНТОС» в ЮНЦ РАН // Вестн. Южного науч. центра РАН. - 2012. - Т. 8, № 3. - С. 91.

1602. Матишов Г.Г., Пономарева Е.Н., Красильникова А.А. О международных научных конференциях, посвященных рыбному хозяйству и аквакультуре в Южном федеральном округе // Вестн. Южного науч. центра РАН. - 2015. - Т. 11, № 1. - С. 109-110.

1603. Моисеев Д.В., Тарасов Г.А. Научно-исследовательское судно «Дальние Зеленцы» на Шпицбергене // Рус. вестн. Шпицбергена. 2013. - № 8. - C. 26-27.

1604. Савельева С.П., Дженюк С.Л., Моисеев Д.В. История, основные задачи и перспективы развития Мурманского регионального отделения Русского географического общества // Материалы III конференции Ассоциации обществ Мурманской области и VI научной сессии Геологического института КНЦ РАН, посвященных Дню российской науки, Апатиты, 9-10 февраля 2015 г. - Апатиты: Изд-во K\&M, 2015. - C. 70-71.

1605. Тарасов Г.А. Шпицбергенская биогеостанция ММБИ // Рус. вестн. Шпицбергена. - 2013. - № 4. - С. 26-27.

1606. Тарасов Г.А. Не оставляй на завтра работу, начатую сегодня // Рус. вестн. Шпицбергена. - 2015. - № 1(15). - С. 22-23.

1607. Участие ММБИ в международном проекте «GreenSeas» / П.Р. Макаревич, Д.В. Моисеев, Е.И. Дружккова, И.В. Берченко, А.А. Олейник, Г.Н. Духно, В.Г. Двореикий // Арктическое морское природопользование в XXI веке - современный баланс научных традиций и инноваций (к 80-летию ММБИ КНЦ РАН): Тез. докл. Междунар. науч. конф. (г. Мурманск, 1-3 апреля 2015 г.). - Апатиты: Изд-во КНЦ РАН, 2015. С. 148-149.

1608. Щепак Л.В., Салмова Н.А., Журавлева Н.Г. Перспективы международного сотрудничества кафедры биоэкологии МГТУ // Современные проблемы экологии и природопользования: Матер. регион. науч.-практ. конф., посвященной 15-летию со дня основания кафедры биоэкологии, Мурманск, 27-28 февраля 2014 г. - Мурманск: Изд-во Мурм. гос. техн. ун-та, 2014. - С. 13-15.

\section{ПРЕПРИНТЫ}

1609. Воскобойников Г.М., Белишева Н.К. Водоросли и здоровье северян: Препр. - Мурманск: Изд. ММБИ КНЦ РАН, 2013. - 32 с. 
1610. Денисов В.В., Фомин С.Ю. Комплексное управление природопользованием на шельфовых морях: аналитический материал и результаты круглых столов. - Мурманск: Premiart.ru, 2011. - 82 с.

1611. Матишов Г.Г., Матишов Д.Г., Шевердяев И.В. Обстоятельства затопления Олимпийской деревни в Адлере. Отчет о результатах экспедиции по маршруту Туапсе-Сухуми (01-08.08.2015 г.). - Ростов н/Д.: Изд-во ЮНЦ РАН, 2015. - 64 с.

1612. Районы ограничения антропогенной деятельности: Печорское море. Нефтегазовый комплекс / А.Н. Болтунов, М.Ю. Дубинин, А.В. Ежов, В.В. Ларионов, А.П. Новоселов, М.А. Пухова, Е.А. Фролова. - Мурманск: Изд. WWF России, 2014. - 76 с.

1613. Чинарина А.Д., Ивакина Ю.И. Мурманский морской биологический институт 1981-2011 гг. (к 30-летию руководства Институтом академиком Г.Г. Матишовым). - Мурманск: Изд. ММБИ КНЦ РАН, 2011. $-58 \mathrm{c}$

\section{КАРТЫ. АТЛАСЫ. АЛЬБОМЫ. КАТАЛОГИ. ОПРЕДЕЛИТЕЛИ}

1614. Абдурахманов Г.М., Набоженко М.В. Определитель и каталог жуков-чернотелок (Coleoptera: Tenerionidae s. str.) Кавказа и юга европейской части России. - М.: Тов-во науч. изд. КМК, 2011. - 361 с.

1615. Атлас климатических изменений в больших морских экосистемах Северного полушария (1878-2013). Регион 1. Моря Восточной Арктики. Регион 2. Черное, Азовское и Каспийское моря / Г.Г. Матишов, С.В. Бердников, А.П. Жичкин, П.Р. Макаревич, С.Л. Дюенюк, В.В. Кульюии, Н.А. Яицкая, В.В. Поважный, И.В. Шевердяев, С.В. Кумпан, И.А. Третьякова, A.E. Цыганкова. - Ростов н/Д.: Изд-во ЮНЦ РАН, 2014. - 256 с.

1616. Времена года. Фотоальбом / М. Паращенко, С. Покуль, С. Шаповалова, О. Панкова, А.Г. Шиараева, Р.М. Савиикий, Г.Б. Бахтадзе / Под общ. ред. Г.И. Скрипки. - Ростов н/Д.: Комитет по охране окружающей среды и природных ресурсов Ростовской области, 2012. - 112 с.

1617. Зонн И.С., Костяной А.Г. Баренцево море. Энциклопедия / Под ред. академика РАН Г.Г. Матишова. - М.: Международные отношения, 2011. -272 c.

1618. Природа морской Арктики глазами биолога: Фотоальбом. Ростов н/Д.: Изд-во ЮНЦ РАН, 2011. - 232 с.

1619. Флора и фауна Донского края: Фотоальбом / C. Покуль, О. Панкова, А.Д. Шмараева, Р.М. Савиикий / Под общ. ред. А. Куренкова. Ростов н/Д.: Комитет по охране окружающей среды и природных ресурсов Ростовской области, 2013. - 112 с. 
1620. Экологический атлас Азовского моря / Г.Г. Матишов, Д.Г. Матишов, О.Е. Архипова, Н.И. Бульишева, Ю.М. Гаргопа, Н.И. Голубева, Ю.И. Инжебейкин, Г.В. Ковалева, А.А. Кондаков, К.В. Красноруикая, Н.В. Лебедева, В.А. Лужняк, М.В. Набоженко, Н.В. Панасюк, Р.М. Савиикий, В.В. Саяпин, В.В. Сорокина, О.В. Степаньян, В.В. Титов, И.В. Толочко, И.В. Шохин. - Ростов н/Д.: Изд-во ЮНЦ РАН, 2011. 328 с.

1621. Atlas of Climatic Changes in Large Marine Ecosystems of the Northern Hemisphere (1878-2013) / G.G. Matishov, S.V. Berdnikov, A.P. Zhichkin, S.L. Dzhenyuk, I.V. Smolyar, V.V. Kulygin, N.A. Yaitskaya, V.V. Povazhniy, I.V. Sheverdyaev, S.V. Kumpan, I.A. Tret'yakova, A.E. Tsygankova, N.N. D'yakov, V.V. Fomin, D.N. Klochkov, B.M. Shatohin, V.V. Plotnikov, N.M. Vakul'skaya, V.A. Luchin, A.A. Kruts / G.G. Matishov, K. Sherman, S. Levitus (Eds.). - Wash., D.C.: NOAA Atlas NESDIS 68, U.S. Gov. Printing, 2014. - 250 p. (DVD).

1622. Atlas of Climatic Changes in Nine Large Marine Ecosystems of the Northern Hemisphere (1827-2013) / G.G. Matishov, S.V. Berdnikov, A.P. Zhichkin, S.L. Dzhenyuk, I.V. Smolyar, V.V. Kulygin, N.A. Yaitskaya, V.V. Povazhniy, I.V. Sheverdyaev, S.V. Kumpan, I.A. Tret'yakova, A.E. Tsygankova, N.N. D'yakov, V.V. Fomin, D.N. Klochkov, B.M. Shatohin, V.V. Plotnikov, N.M. Vakul'skaya, V.A. Luchin, A.A. Kruts / G.G. Matishov, K. Sherman, S. Levitus (Eds.). - Wash., D.C.: NOAA Atlas NESDIS 78, 2014. - 131 p. URL: http://data.nodc.noaa.gov/woa/PUBLICATIONS/AtlasLME-2014.pdf

\section{АВТОРЕФЕРАТЫ КАНДИДАТСКИХ И ДОКТОРСКИХ ДИССЕРТАЦИЙ}

1623. Березина И.А. Исследование поведения настоящих тюленей в условиях неволи: Автореф. дис. ... канд. биол. наук (03.02.04 зоология). - Петрозаводск, 2013. - 23 с.

1624. Кавцевич Н.Н. Морфологические и цитохимические особенности клеток крови морских млекопитающих в связи с адаптацией к среде обитания: Автореф. дис. ... докт. биол. наук (03.03.01 - физиология; 03.02.04 - зоология). - Петрозаводск, 2011. - 39 с.

1625. Минзюк T.B. Морфофункциональные особенности лейкоцитов тюленей разного возраста: Автореф. дис. ... канд. биол. наук (03.03.01 физиология). - Петрозаводск, 2012. - 23 с.

1626. Михайлюк А.Л. Техногенное шумовое загрязнение Баренцева моря и его влияние на биологию кольчатой нерпы: Автореф. дис. ... канд. биол. наук (25.00.28 - океанология). - Мурманск, 2012. - 23 с.

1627. Олейник A.A. Фитопланктон Кольского залива: Автореф. дис. ... канд. биол. наук (25.00.28 - океанология). - Мурманск, 2011. - 23 с. 
1628. Сапрыгин В.В. Изучение распределения хлорофилла $a$ в Азовском море по данным дистанционного зондирования Земли из космоса и результатам судовых измерений: Автореф. дис. ... канд. геогр. наук (25.00.28 - океанология). - Ростов н/Д., 2011. - 24 с.

1629. Светочев В.Н. Биология и экология гренландского тюленя (Phoca groenlamdica Erxleben, 1777) беломорской популяции на первом году жизни: Автореф. дис. ... канд. биол. наук (25.00.28 - океанология). Мурманск, 2013. - 24 с.

1630. Семин В.Л. Экология полихет Азовского моря и лиманов российской части его побережья: Автореф. дис. ... канд. биол. наук (25.00.28 - океанология). - Мурманск, 2011. - 25 с.

1631. Усягина И.С. Распределение и пути миграций искусственных радионуклидов в экосистеме Баренцева моря: Автореф. дис. ... канд. геогр. наук (25.00.28 - океанология). - Мурманск, 2012. - 23 с.

1632. Фролов A.A. Фауна, распространение и экология моллюсков надсемейства Pisidioidea различных водных объектов Северо-Запада России: Автореф. дис. ... канд. биол. наук (03.02.08 - экология (биология). - Борок, 2011. - 24 с.

1633. Шавыкин А.А. Эколого-океанографическое сопровождение освоения нефтегазовых месторождений Арктического шельфа (на примере Баренцева моря): Автореф. дис. ... докт. геогр. наук (25.00.28 океанология). - Мурманск, 2015. - 46 с.

1634. Яиџкая Н.A. Термохалинный режим Каспийского моря при изменении уровня: Автореф. дис. ... канд. геогр. наук (25.00.28 океанология). - Мурманск, 2012. - 28 с.

\section{ПАТЕНТЫ}

1635. Автономная система оперативного биологического мониторинга и индикации (варианты): Пат. 101838 Российская Федерация, 27.08.10. / А.В. Гудимов. - Бюл. - 2011. - № 3.

1636. Плавучее устройство для транспортировки морских млекопитающих: Пат. 147813 Российская Федерация, 16.10.14 / А.Л. Михайлюк, Д.Г. Иикулов, А.Р. Трошичев, И.М. Кощер. - Бюл. - 2014. - № 32.

1637. Приборный комплекс для непрерывной регистрации и измерения двигательной активности двустворчатых моллюсков: Пат. 2452949 Российская Федерация, 31.01.11 / А.В. Гудимов, А.И. Бурдыгин, В.П. Нестеров, В.Ф. Митрофанов. - Бюл. - 2012. - № 16. 
1638. Приманка искусственная для ярусного лова рыбы: Пат. 2494618 Российская Федерация, 20.12.11. / В.М. Муравейко. - Бюл. 2013. - № 28.

1639. Свидетельство о регистрации базы данных «Фитопланктон Гренландского, Баренцева, Белого, Карского морей» № 2014620337 Российская Федерация, 25.02.2014 г. / Д.В. Моисеев, П.Р. Макаревич, Е.И. Дружкова, А.А. Олейник, Г.Н. Духно. Организация-разработчик Федеральное государственное бюджетное учреждение науки Мурманский морской биологический институт Кольского научного центра Российской академии наук.

1640. Система оперативного биологического мониторинга и индикации: Пат. 2437093 Российская Федерация, 11.05.10 / А.В. Гудимов. - Бюл. 2011. - № 35 .

1641. Способ очистки прибрежной зоны морей от комплексного загрязнения с использование двустворчатых моллюсков: Пат. 2494978 Российская Федерация, 13.06.12 / А.В. Гудимов. - Бюл. - 2013. - № 28.

1642. Способ биологической очистки литоральной зоны морей от нефтепродуктов: Пат. 2505489 Российская Федерация, 27.01.14 / А.В. Гудимов. - Бюл. - 2014. - № 3.

1643. Способ оценки уязвимости прибрежно-морских зон от нефти, нефтепродуктов и других химических веществ и построения соответствующих карт уязвимости: Пат. 2563549 Российская Федерация, 25.08.2015 / А.А. Шавыкин, О.П. Калинка, П.С. Ващенко, А.А. Карнатов. - Бюл. 2015. - № 26.

1644. Сухой экстракт фукуса, способ его получения и антикоагулянтная мазь на его основе: Пат. 2506089 Российская Федерация, 10.02.14 / Е.Д. Облучинская. - Бюл. - 2014. - № 4.

1645. Устройство для изготовления препаратов биологических клеток на покровных стеклах ценрифугированием: Пат. 113178 Российская Федерация / И.А. Ерохина, Н.Н. Кавцевич, Т.В. Минзюк. - № 2011141973/05; заявл. 17.10.2011; опубл. 10.02.2012. - Бюл. - 2012. - № 4.

1646. Устройство для биологической очистки морских вод от техногенных загрязнений: Пат. 126327 Российская Федерация, 04.09.12 / Г.М. Воскобойников, М.В. Макаров. - Бюл. - 2013. - № 9.

1647. Устройство для биологической очистки морских вод от техногенных загрязнений (варианты): Пат. 136037 Российская Федерация, 27.12.13 / Г.М. Воскобойников, М.В. Макаров. - Бюл. - 2013. - № 36.

1648. Устройство для подводного отбора проб: Пат. 150517 Российская Федерация, 20.01.15. / М.В. Макаров. - Бюл. - 2015. - № 5. 


\section{НАУЧНО-ПОПУЛЯРНЫЕ КНИГИ И СТАТЬИ}

1649. Жук В.А., Адров Н.М. Союз науки и образования в ММРК им. И.И. Месяцева (Северное научно-исследовательское общество курсантов, студентов, преподавателей и ученых «Грумант») // Рыбные ресурсы. - 2011. - № 1. - С. 38-41.

1650. Жук В.А., Клочков Д.Н., Адров Н.М. Стратегическое партнерство - сплав образования, науки и производства // Север промышленный. - 2012. - № 1(41). - С. 11-15.

1651. Зензеров В.С., Терехов А.Э., Никитин Н.В. Новые данные по способам охоты поселенцев Восточного Мурмана на северных оленей (история, орудия и способы лова) // Вестн. Кольского научн. центра PAH. - 2014. - № 3(18). - С. 30-37.

1652. Как обогатить охотничьи угодья кряквой / H.X. Ломадзе, Н.В. Лебедева, С.Г. Коломейцев, В. Говорунов, В.В. Куликов // Охота. 2011. - № 5. - С. 36-38.

1653. Нехаев И.О. Побережье Баренцева моря (фото из путешествий) // GEO. - 2013. - № 4(181). - C. 21.

1654. Савицкий Р.М. Добро пожаловать белые аисты // Искра. 2015. - № 15(11612), 16 апр.

1655. Савищкий Р.М. Жители Ростовской области построили девять гнезд для аистов // Крестьянин. - 2015, 23 апр.

1656. Савицикй P.M. Как ростовские ученые строят гнезда аистам // Вечерний Ростов. - 2015. - № 65-66(16334-16335), 10 апр.

1657. Савиикий Р.М. Настольная книга для любителей природы // Наше время. - 2015. - № 66(22952), 17 март.

1658. Савицкий P.M. Научная традиция: никак без экспедиции // Академия. - 2015. - № 1(637), 17 янв.

1659. Савицкий Р.M. Путь в науку начинается в «Радуге»// ЭКОлогический альманах. - 2015. - №1, 6 февр. 


\section{Авторский указатель}

Аарвак T.

Абдурахманов Г.М.

Аверкиев Д.Б.

Авилова К.В.

Авилов К.В.

Адров М.Н.

Адров Н.M.

Аистов Е.А.

Александрова Л.Е.

Алексеева В.В.

Алексеева Я.И.

Алексеев А.В.

Алёшина Е.Г.

Алёшина Н.В.

Амахина М.A.

Андреева С.И.

Анисимова Н.А.

Анисимова О.В.

Анисимов Ю.А.

Антонова Е.Г.

Антонов В.И.

Анциферова А.Р.

Архипова О.Е.

Ахметова М.М.

Ахметчина О.Ю.

Ахметшина С.И.

Бабанин Ю.А.

Бабушкин М.B.

Багатько О.Ю.

Баданин Ю.А.

Баева Т.С.

Бакаева Е.Н.
831,864

$761,772,778,1614$

1236,1237

1217

1424

1578

$1-10,116,1530,1531,1578,1649,1650$

173

$1235-1237$

1237

978

1236,1237

$186,598,601,1323,1376$

186

1237

375

$445,447,478$,

1237

843

1237

1236

1234,1235

$216,218,1620$

1237

365-370, 425, 434, 466, 478

1233

1294

980

844

$807-808,911,1538$

1234

1336 


\begin{tabular}{|c|c|}
\hline Балыкин П.А. & $672-674,738,739,1260,1441$ \\
\hline Баранов С. & 129 \\
\hline Бардан С.И. & $117-125,154,232-236,264,1227$ \\
\hline Баркан В.Ш. & $1233-1237$ \\
\hline Бартницкий Й. & 1385 \\
\hline Барышникова Н.В. & 1330 \\
\hline Батанов Р.Л. & 705 \\
\hline Баyx X.A. & 33 \\
\hline Бахтадзе Г.Б. & 1616 \\
\hline Белая М.М. & 740 \\
\hline Беликов С.Е. & 978 \\
\hline Белишева Н.К. & 1609 \\
\hline Белькович В.М. & 981 \\
\hline Беляевская Н.А. & $1234,1236,1237$ \\
\hline Бергер В.Я. & $64,73,74,75,127,153$ \\
\hline Бердников С.В. & $\begin{array}{l}159,166,182,188,189,204,215-223,1228,1239, \\
1318,1322,1335,1365,1372,1373,1431,1615\end{array}$ \\
\hline Березина И.А. & $968,1041-1046,1087,1088,1107,1623$ \\
\hline Берестовский Е.Г. & $623,627,1442$ \\
\hline Берлина Н.Г. & 1237 \\
\hline Берченко И.В. & $301-305,1270,1607$ \\
\hline Беспалова Л.А. & 1278 \\
\hline Бианки В.В. & 809 \\
\hline Бирюкова С.В. & 371 \\
\hline Бирюков А.А. & 742 \\
\hline Блиновская Я.Ю. & 1429 \\
\hline Бобров К.А. & $59,128,170,304$ \\
\hline Богданов П.В. & 1236,1237 \\
\hline Болтачев А.P. & 1258,1259 \\
\hline Болтунов А.Н. & $965,978,980,1007,1379,1612$ \\
\hline Бондарев О.В. & 626,677 \\
\hline Бонк А.А. & 705 \\
\hline Боровичев Е.А. & 1237 \\
\hline Бранько В.Е. & 1237 \\
\hline
\end{tabular}


Бреславец Е.В.

Брехунцов А.M.

Брязгин В.Ф.

Будилова Е.В.

Булатова С.В.

Булышева Н.И.

Бурдыгин А.И.

Бурцева Л.В.

Буханцева С.В.

Ваарамаа К.

Вакатов А.В.

Валуйская Д.А.

Васильева Е.Д.

Васильев А.М.

Ващенко А.В.

Ващенко П.С.

Вдовин И.В.

Вдодович И.В.

Веденев А.И.

Венгер М.П.

Вербицкий P.Е.

Вербицкий Е.В.

Викрищук А.Д.

Вильнет А.А.

Винарский М.В.

Виноградов А.Н.

Вира Ю.

Вишневская О.А.

Владимирова О.М.

Водопьянова В.В.

Войнов В.Б.
1233

1261

446

1100, 1197, 1500, 1533

$1233,1234,1237$

$372,373,450,455,465,781,782,1311,1620$

1637

1383

1234, 1235

1385

705

1331-1333, 1357, 1386, 1388-1390

671

$1443,1444,1453,1459$

609

$199,1321,1329,1334,1364,1380-1382,1400$, $1401,1425,1426,1428,1430,1445-1447,1475-$ $1478,1494,1496,1504,1643$

$1233,1234,1236,1237$

1277

1424

231, 237-250, 254, 263, 346, 1270

$742,1311,1322$

1950, 1951, 1054, 1112-1114, 1179, 1198, 1311

1431

609,610

374

129

1385

1234,1237

1067

231, 246-249, 255, 265, 266, 277, 287, 293, 1539 973, 974, 1050-1055, 1112-1114, 1137, 1169, 1170, 1179, 1191, 1193, 1196, 1198, 1471, 1541 
Волошин С.В.

Воронова Е.В.

Ворошилова И.С.

Воскобойникова О.С.

Воскобойников Г.М.

Востряков К.В.

Вылегжанин А.Н.

Вязникова В.С.

Гаврилов В.М.

Гаврило М.В.

Гайденок Н.Д.

Гайнанова Р.И.

Галактионов К.В.

Гарбуль Е.А.

Гаргопа Ю.М.

Гасанова А.Ш.

Гвинн Д.

Гвяздович Д.Дж.(Я.)

Генералов С.Г.

Герасимова М.B.

Гладких А.С.

Говорунов В.Н.

Голиков А.В.

Головкина Е.М.

Головко Г.В.

Голубева Н.И.

Голубева Т.Н.

Голяк И.В.

Гонтарь О.Б.

Гоппен T.C.

Горбачев В.В.

Горбунов Ю.А.
$1233,1234,1236,1237$

1234

375

624

$11,261,530,532-536,559,560,567,568,613$, $614,618,728-730,734,743,752,1338,1339$, $1493,1498,1609,1646,1647$

1233

1491

376

1591

$813,831,864,865,1147,1240,1399,1429$

$205,959,961$

$1233,1234,1237$

1029

$370,377,378,425,434,466,478,479$

130-135, 167, 186, 208, 379, 1231, 1620

164

1385

$810,1033,1273$

1233,1234

$30-32,65-76,153,542,543,617$

$960,1056,1173$

907, 908, 947, 1501, 1652

384, 489

380,450

1317

$1349,1383,1482,1620$

1234

559, 560, 728, 743

1233-1235, 1237

1233-1235

705

1379 
Гордеева Е.Л.

Горемыкина О.В.

Горяева А.А.

Горяев Ю.И.

Григорьев В.А.

Григоренко К.С.

Гроголь О.Н.

Громов В.В.

Громов М.С.

Гудимов А.В.

Данилов И.Д.

Даувальтер М.В.

Дашкевич Л.В.

Дворецкий А.Г.

Дворецкий В.Г.

Демидов А.Б.

Демченко В.А.

Демченко Д.Л.

Денисов В.В.

Дерябин А.А.

Дженюк С.Л.

Дикаева Д.Р.

Динкевич М.А.

Дмитриева Н.С.

Добрынин Д.В.

Долгоносов Б.М.

Дорофеева Е.А.
154

1237

814-817

$817,842,859,860,866,867,869,911,975,979$, $1009,1238,1542,1595$

$745,1546,1601$

$173,174,175,178$

$1233,1234,1237$

$537-541,601$

$137,171,184,221,1350$

381-383, 482-485, 1057-1063, 1192, 1295-1306, $1325,1326,1635,1637,1640-1642$

1234,1235

1235,1237

216

$200,319-343,385-413,488,1228,1232,1448-$ $1450,1534-1536,1550,1592$

306-343, 346, 394-413, 1450, 1534-1536, 1607

289

671

1237

$12,79,183,184,187,1229,1443,1444,1451-$ $1460,1488-1490,1495,1502,1503,1508,1610$

$137,214,221,808,1294,1333,1538$

$79,126,136,139-141,152,177,185,187,204$, $219,737,1229,1252-1254,1261,1262,1271$, $1279,1307-1309,1461-1465,1483-1486,1488$, $1495,1503,1508,1538,1604,1615$

$370,414-425,434,466,467,478,479,493-495$

$818,819,905$

1234

868

120

625 
Дружкова Е.И.

Дубинин М.Ю.

Духно Г.Н.

Дьячкова Г.М.

Дюжова К.В.

Ежов А.В.

Елисеева О.И.

Емелина А.В.

Емельянов К.С.

Ермилов С.Д.

Ермолаев А.И.

Ерохина И.А.

Ершов М.О.

Жарова Ю.А.

Желудкова А.И.

Жичкин А.П.

Жук В.А.

Журавлева Н.Г.

Заборщикова В.В.

Заборщиков Н.В.

Заботкина Е.A.

Завалко С.Е.

Загородняя Ю.А.

Загудеева В.В.

Зайцев А.А.

Зайцев А.П.

Залота А.К.

Захаров Д.В.
$76,267-269,275,278,279,289-292,1228,1270$, 1607,1639

1612

172, 209-214, 217, 221, 1321, 1607, 1639

1233

47,77

$817,820-826,842,861-863,866,867,911,1009$, 1612

167

741, 1064-1067, 1172, 1173

1324

1068

811, 827-830, 884-886, 896, 897, 909, 942

$16,967,968,1062,1069-1086,1110,1111,1645$

1237

1087,1088

$962,981,1089,1090$

$12,126,129,136,142-149,152,160,177,183-$ $185,187,204,219,1260,1279,1441,1454,1459$, $1460,1466-1470,1489,1495,1502,1503,1615$

1649,1650

13, 627, 694, 704, 731-733, 735, 736, 744-751, 753-757, 1047-1949, 1100, 1194, 1197, 1207, 1209-1216, 1218, 1219, 1500, 1532, 1533, 1546, $1579-1589,1608$

1237

1237

245

618

1277

1235

964, 1091-1094, 1136, 1137, 1196

$1233,1235-1237$

465,1311

369 
Зензеров В.С.

Зимина О.Л.

Знаенко В.С.

Золотарева А.Е.

Золотков А.А.

Зонн И.С.

Зубакин В.А.

Зубарева А.В.

Зубков А.В.

Зубова Е.Ю.

Зуева М.Н.

Зуев Ю.А.

Зырянов С.В.

Ивакина Ю.И.

Иванова Г.Г.

Иванов В.А.

Иванов В.П.

Иванов С.А.

Иванов Ю.В.

Иваненко Н.Ю.

Ивлиева О.В.

Игнатьев А.C.

Игнатьев C.M.

Игнатенко В.И.

Извекова Г.И.

Ильина Л.П.

Ильина Т.A.

Ильин Г.В.

Ильинский В.В.

Ильясов А.Х.

Илющенко А.M.
$14,15,426,440,1064,1082-1084,1095-1097$, $1101,1174,1208,1651$

$370,425,427-434,447,466,467,477-480,487$

1234

$77,1243,1311$

1236,1237

1617

832,910

1233

1234

$730,734,743,1493,1498$

1234,1235

435-438

963

28,1613

1236,1237

1239

672-674

201-203

$1233-1235$

833-843, 887

1278

1233

1277

1233,1234

$1017,1098,1099$

1230

1591

$137,183,1228,1233-1237,1263,1337,1340$ $1354,1359,1365,1369,1373,1377,1383,1385-$ 1388, 1390, 1394, 1395, 1460, 1490, 1495, 1508 $259,260,1493$

1236,1237

426, 439, 440, 1101, 1208 


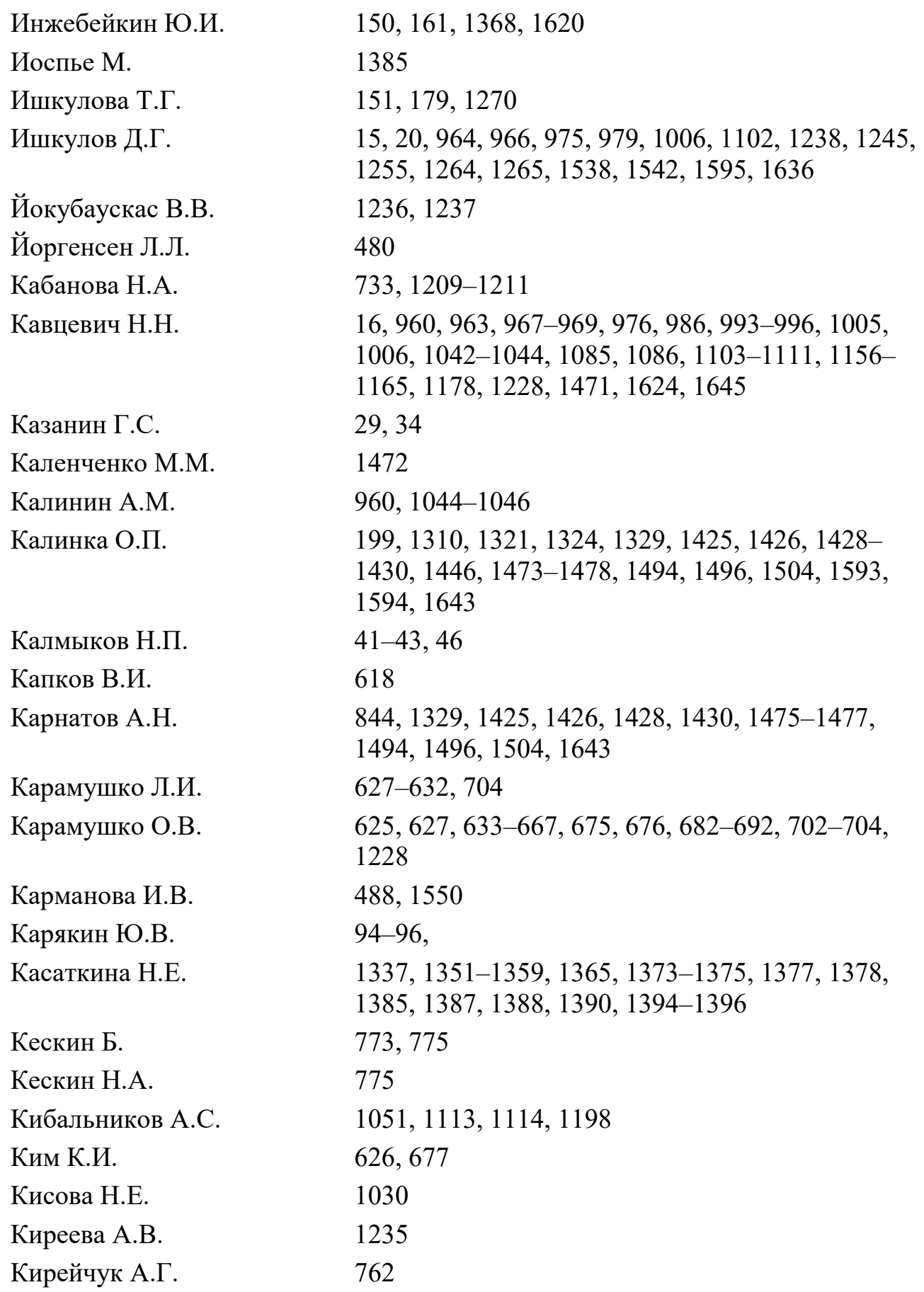




$\begin{array}{ll}\text { Кириллова Е.Э. } & 189 \\ \text { Киричек О.П. } & 1233-1235,1237 \\ \text { Клапатюк А.М. } & 1045 \\ \text { Клеванный К.А. } & 1380-1382 \\ \text { Клепиковский Р.Н. } & 1324 \\ \text { Клещенков А.В. } & 162,189,1540 \\ \text { Климова Т.Н. } & 1277 \\ \text { Климук В.С. } & 46 \\ \text { Клиндух М.П. } & 544-555,1511-1514 \\ \text { Клочков Д.Н. } & 1650 \\ \text { Клычева А.Н. } & 778 \\ \text { Кляйн Х. } & 1385 \\ \text { Книжников А.Ю. } & 1429 \\ \text { Ковалева Г.В. } & 21,35,77,164,1243,1269,1366,1431,1620 \\ \text { Коваленко Е.П. } & 453 \\ \text { Коваленко М.В. } & 742 \\ \text { Ковблюк Н.М. } & 17 \\ \text { Койпиш Е.В. } & 1236,1237 \\ \text { Кокин О.В. } & 36-39, \\ \text { Колбеева М.В. } & 556,615 \\ \text { Коломейцев С.Г. } & 812,898-900,907,947,1479,1497,1501,1652 \\ \text { Коломийчук В.П. } & 587 \\ \text { Кольцова А.Н. } & 1233,1234 \\ \text { Комракова Д.Г. } & 449,557,558,582 \\ \text { Кондаков А.А. } & 969,970,976,1179,1379,1620 \\ \text { Конюхов И.Б. } & 1233,1236,1237 \\ \text { Копылов А.И. } & 245 \\ \text { Корнева Ж.В. } & 1171 \\ \text { Корнеева Г.А. } & 121,125,154 \\ \text { Корниенко С.А. } & 1171 \\ \text { Королев В.В. } & 1233-1237 \\ \text { Короткова Т.Д. } & 1233-1237 \\ \text { Корякин А.С. } & 1233-1235 \\ \text { Костин Д.А. } & \\ \text { 208 } & \end{array}$


Костяной А.Г.

Коулсон С.Дж.

Кощер И.М.

Краевская М.Р.

Красильникова А.А.

Краснова В.В.

Краснов Ю.В.

Красноруцкая К.В.

Кременецкий В.В.

Кренева К.В.

Кренева С.В.

Кропянко Л.В.

Кругликова Е.Н.

Кудрявцева Е.О.

Кудрявцева О.Ю.

Куклина М.M.

Куклин В.В.

Куликова Т.С.

Куликов В.В.

Кулыгин В.В.

Кумпан С.В.

Куранов Ю.Ф.

Курчак А.Н.

Кушнир B.M.

Кушнаренко А.И.

Лазуренко В.В.

Лапинскайтене Л.В.

Ларионов В.В.

Ларина Т.М.

Лебедева Н.В.
1617

$763,810,1273$

1636

1235

1602

978, 981

$809,813,831,832,842,845-870,911,948,971$, $1029,1147,1228,1240,1399$

$35,48,49,1620$

289

$344,345,1269,1312,1314-1317,1336,1360,1361$

$344,345,1312-1317,1336,1360,1361$

1278

$1235-1237$

$559,560,743$

$624,626,627,668-670,677,704$

$873,874,1017,1026,1027,1030,1031,1098$, $1099,1115-1134$

871-874, 1018-1030, 1128-1134, 1171

1233

$812,907,947,1497,1501,1652$

204, 215, 216, 218-220, 1365, 1372, 1615

204, 219, 1615

728

1234

216,1239

1441

$1094,1135,1136$

1234,1235

$270,276,278,279,1241,1595,1612$

$732,735,736,744,1212,1533,1584,1588$

$17,18,763,779,780,810-812,828-830,832$,

875-902, 907-910, 934-940, 943-947, 1032-1034, $1217,1230,1242,1273,1362,1363,1479,1497$,

$1501,1591,1596,1597,1620,1652$ 
Лебедев В.Д.

Левитус $\mathrm{C}$.

Левченко М.В.

Леппанен А.-П.

Лесихина Н.А.

Литвинов Ю.В.

Лихтанская Н.В.

Ломадзе Н.X.

Лужняк В.А.

Лукин Л.Р.

Лукичева Л.А.

Лурье П.М.

Лычагина Ю.М.

Любина О.C.

Любин П.А.

Ляймер А.В.

Макаревич П.Р.

Макарова Е.C.

Макарова М.Н.

Макарова Э.В.

Макаров М.В.

Малавенда С.В.

Малавенда С.C.

Малашенко С.В.

Манушин И.Е.

Марахонич A.B.

Маркитан Л.В.

Марковская Е.Ф.

Маслич М.А.
780,1034

204, 219

$1234,1235,1237$

$1356,1375,1385$

1233,1234

1138-1146, 1196

216

812, 888-894, 896, 898-900, 902, 907, 908, 943, $944,947,1479,1497,1501,1652$

$671,693,745,1546,1620$

1379

1233-1237

186

$217,218,221$

$136,370,377,384,425,430,431,434,441-447$, $466,467,478-480,489,1228$

$445,466,478,480$

$258-260$

$19,79,136,205,246,248,249,269,271-279,346$, $959,961,979,1229,1243-1245,1263-1266,1268$, $1271,1427,1539,1598,1607,1615,1639$

1236,1237

1510

$1235-1237$

530, 535, 536, 561-568, 578, 579, 582-586, 613, 614, $618,728,752,1228,1339,1498,1637,1646-1648$ $448,449,530,531,542,543,557,558,569-586$, $593,611,612,614,617,1364,1437$

$449,542,543,557,558,617,626,677$

1235

376

764, 776-778

$818,819,903-905$

531

1028 


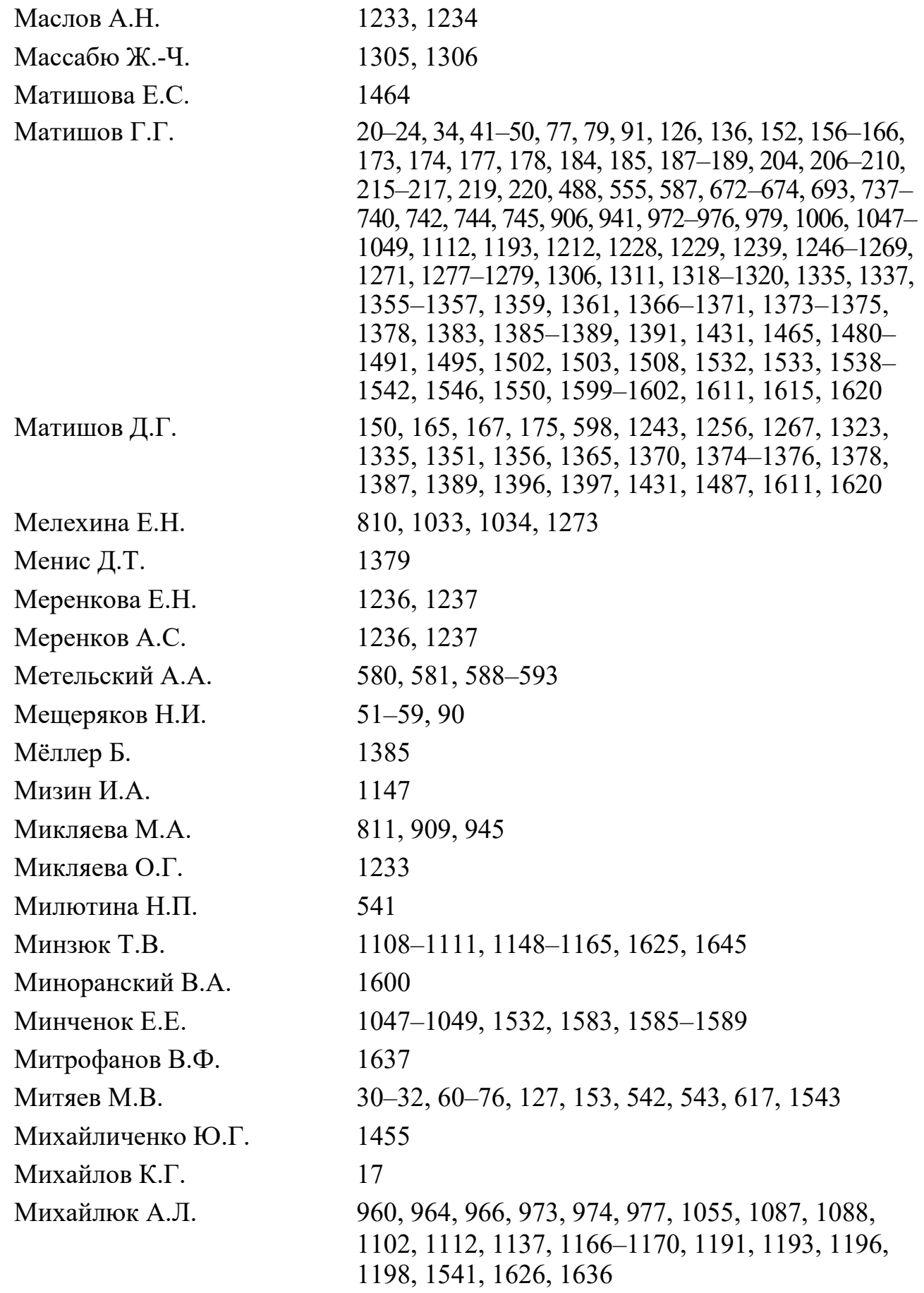
$173,174,177,178,184,185,187-189,204,206-210$, 215-217, 219, 220, 488, 555, 587, 672-674, 693, 737740, 742, 744, 745, 906, 941, 972-976, 979, 1006, 1047$1049,1112,1193,1212,1228,1229,1239,1246-1269$, 1271, 1277-1279, 1306, 1311, 1318-1320, 1335, 1337, 1355-1357, 1359, 1361, 1366-1371, 1373-1375, $1378,1383,1385-1389,1391,1431,1465,1480$ $1491,1495,1502,1503,1508,1532,1533,1538-$ $1542,1546,1550,1599-1602,1611,1615,1620$ $150,165,167,175,598,1243,1256,1267,1323$, $1335,1351,1356,1365,1370,1374-1376,1378$, $1387,1389,1396,1397,1431,1487,1611,1620$ $810,1033,1034,1273$

1379

1236,1237

1236,1237

$580,581,588-593$

$51-59,90$

1385

1147

$811,909,945$

1233

541

1108-1111, 1148-1165, 1625, 1645

1600

$1047-1049,1532,1583,1585-1589$

1637

$30-32,60-76,127,153,542,543,617,1543$

1455

17

960, 964, 966, 973, 974, 977, 1055, 1087, 1088, 1102, 1112, 1137, 1166-1170, 1191, 1193, 1196, $1198,1541,1626,1636$ 
Мишина Н.Н.

Моисеев Д.В.

Моргунов Б.А.

Морозов Г.С.

Морозов Е.А.

Мошаров С.А.

Муравейко А.В.

Муравейко В.M.

Набоженко М.В.

Набоженко С.В.

Налбандян А.

Недоспасов А.А.

Нель А.

Ненашева-Желудкова А.И.

Нестеров В.П.

Нехаев И.О.

Никитин Н.В.

Никитский Н.Б.

Никифоров В.В.

Николаева Л.А.

Николаева Н.Г.

Николаев С.Д.

Нисси М.

Новенко Е.Ю.

Новикова А.Н.

Новиковский Н.M.

Новоселов А.П.

Носарева О.А.

Облучинская Е.Д.

Овсепян Я.С.

Огнетов Г.Н.
$168,250,734$

$126,129,136-138,152,163,169-172,177,183-$ $185,187,209-214,217,220,221,346,378,1228$, $1266,1271,1279,1321,1373,1492,1502,1503$, $1538,1594,1598,1603,1604,1607,1639$

1491

384,489

1324

289

741,1172

$1064,1173,1174,1638$

$35,77,372,373,380,450-455,465,496,761,762$, 764-778, 780-782, 1311, 1614, 1620

780

1358,1385

290

762

$1175-1178$

1063,1637

$370,374,425,434,456-464,467,478,479,705,1653$ 1651

774

$965,980,1007$

1234

1399

33

1385

$47,48,49$

1234

601

1612

$1233-1237$

552-555, 594-599, 616, 1323, 1376, 1510-1522, 1644 33

205, 959, 961, 1379 
Олейник А.А.

Олейник Д.И.

Олейников Е.П.

Оленин А.Л.

Омельчук Р.В.

Опря Т.В.

Оттесен О.

Охотник B.P.

Паатеро Ю.

Павельская Е.В.

Павленко А.А.

Павлова Л.В.

Павлова Л.Г.

Павлова М.А.

Палатов Д.М.

Панасюк Н.В.

Панкова О.

Панов В.Д.

Пантелеева Н.Н.

Панфилова П.Н.

Парада С.Г.

Паращенко М.

Пастухов И.А.

Пахомова Н.А.

Пахомов М.В.

Перемотина А.Г.

Пестов П.В.

Петрова М.Н.

Петроченкова М.А.

Печерская Ю.В.

Поважный В.В.

Погодина И.А.

Погребов В.Б.
$277,280-285,287,1270,1539,1607,1627,1639$

778

969,1179

173

176

1236,1237

$744,753,755-757,1047-1049,1194,1212,1219$, 1532,1533

$1233-1235,1237$

1385

$1359,1377,1378,1397$

1601

$435-438,468-472$

179

$231,250-255,286,287,293,1330$

374

1363,1620

1616,1619

186

$370,473-477,479,1272$

705

44

1616

180,181

$1583,1585-1589$

964, 966, 1102, 1137, 1170, 1180-1191, 1196

599

$1233,1236,1237$

1324

1235,1237

$1235-1237$

$174,178,182,1239,1243,1269,1311,1615$

$33,78,79,1545$

1429 
Подольская О.А.

Подольский Н.И.

Пожарицкая О.Н.

Покуль С.

Поливцева Е.И.

Поликарпова Н.В.

Полищук Ю.В.

Полищук Ю.С.

Польшина Т.H.

Польшин В.В.

Полухин А.C.

Пономарев А.B.

Пономарева Е.Н.

Пономаренко В.О.

Пономаренко Е.П.

Попова O.A.

Потапов В.В.

Прокина О.И.

Пронин Н.М.

Пуговкин Д.В.

Пухова М.A.

Разумовский Л.В.

Разновская С.В.

Разномазов B.M.

Ракитенко К.Ю.

Расилайен $\mathrm{T}$.

Расхожева Е.В.

Ратомская И.В.

Рейникайнен К.

Решетников Ю.С.

Решетова O.3.

Родимцев А.C.

Романова Ю.В.

Рощевский Ю.К.
1234-1237

1235

1510

1616,1619

$1192,1325,1326$

1233, 1235-1237

1233,1234

1193

587

$35,50,77,174,1311,1371$

289

$779,901,1230$

693, 738-740, 742, 1546, 1602

601

182

$659,660,675,676$

35,77

1236,1237

1171

256-261, 600, 734, 752, 1338, 1493, 1498

1429, 1612

122

446

601

1235

1385

627, 678-681, 704, 706

1233,1234

1385

661-666, 682-692

1235

811,909

1237

910

214 
Руденко О.В.

Русских С.И.

Рыжик И.В.

Рыжкова Т.М.

Рыжов М.В.

Сабиров Р.М.

Савельева С.П.

Савикин А.И.

Савицкая C.C.

Савицкий P.M.

Савчис Н.M.

Сажин А.Ф.

Салатие Д.

Салмова Н.А.

Самохин Р.В.

Самсонова Н.Ю.

Сапожников Ф.В.

Сапрыгин В.В.

Сарвилина С.В.

Саяпин В.В.

Старцев А.В.

Светлова М.В.

Светочева О.Н.

Светочев В.Н.

Свистунова Л.Д.

Свитина B.C.

Селифонова Ж.П.

Семенов А.В.

Семенова В.С.

Семин В.Л.

Сербов Н.Г.
$33,80,91$

1235

$261,530,531,536,556,568,600,602-615,734$, $752,1339,1498,1522$

1234-1237

1235

384, 489

1604

481, 781, 782

942

895, 901, 906, 909, 912-944, 1230, 1335, 1368, $1384,1616,1619,1620,1654-1659$

1233,1234

289, 291

694, 746-751, 1194, 1213-1215, 1583, 1589, 1608

1236,1237

1237

1311

$216,288,1322,1628$

379

1277,1620

1456,1457

695, 970, 978, 987-1005, 1195, 1432

965, 970, 978, 980, 982-996, 1001-1007, 1163-1165, 1195, 1379, 1432, 1499, 1629

1312

$382,383,482-485$

696, 1274-1276, 1548, 1549

1233,1234

$965,978,980,1007,1379$

$432,433,465,486,487,1311,1630$

123-125, 235, 236, 1227 
Серветник В.В.

Сергеева В.М.

Сергеев А.A.

Сергиенко Л.А.

Сидорова И.С.

Скрылева Л.Ф.

Смирнова Е.В.

Смирнов А.А.

Смирнов Г.В.

Смирнов В.В.

Смирнов В.И.

Смоляр И.В.

Сойер В.Г.

Соколова Е.Л.

Соколова С.А.

Соколова С.В.

Солатие Д.

Солвенчук Л.Л.

Соловьева А.А.

Солхой $\mathrm{T}$.

Сон M.O.

Сонина А.В.

Сорокина В.В.

Сорокин Ю.И.

Соснина В.Н.

Спиридонов В.А.

Старцев А.В.

Степанова А.Ю.

Степаньян O.B.

Степанюк И.А.

Стоцкая Е.Э.

Ступникова А.Н.

Сусленкова Е.Н.
1235-1237

290-292

1235-1237

531

1233-1236

$811,830,897,909,945$

697-704, 706, 1380-1382

1233-1236

173

153

1233-1237

204, 219

$174,178,1391$

1491

1400, 1401

615

$1356,1358,1375$

705

175

810,1273

454

531

$216,218,1620$

1276

1236, 1237

$868,1240,1311,1399$

693

33

22-24, 173, 174, 178, 1239, 1257-1259, 1267, $1269,1277,1367,1391,1620$

1064, 1174

910

305

1233-1237

216 
Суткайтис О.К.

Суханова В.M.

Суханова И.Н.

Суханова Н.M.

Сухотин А.А.

Сыроечковский Е.В.

Талденкова Е.Е.

Тарасов Г.А.

Таскаева А.А.

Телятник С.И.

Терехин A.T.

Терехов А.Э.

Типисова Е.В.

Титов В.В.

Тихомирова А.В.

Тишков А.А.

Ткачук И.В.

Толмачева Е.Л.

Толочко И.В.

Толстик Г.Г.

Томкович П.С.

Третьякова И.А.

Трофимова Н.В.

Трофимов И.К.

Троценко А.А.

Трошичев А.P.

Трусова М.Г.

Турищева К.Ю.

Узденов А.М.

Усягина И.С.

Утевский С.Ю.

Уткин М.Ю.

Утробин М.Г.
1233-1237

289

289-292

1233

870

910

33

$19,29,34,40,59,79-91,1262,1268,1603,1605,1606$

$763,810,1273$

1236,1237

1100

1651

426,1097

1620

945

1319,1320

1235

1236,1237

$35,50,77,1620$

1336

946

$204,216,219,1615$

616

705

$1100,1197,1216,1500,1533$

$1008,1046,1636$

1235

1236,1237

908

222, 1337, 1352-1355, 1359, 1365, 1369-1371, 1373, $1374,1377,1378,1385-1390,1392-1398,1507,1631$ 488,1550

1235

$1234-1237$ 
Фарион Д.А.

Федоренко А.Г.

Федорокова Ю.В.

Федотова Л.В.

Федухина Т.Я.

Филатова Т.Б.

Фисак Е.М.

Флинт М.В.

Фомин В.В.

Фомин С.Ю.

Фролова Е.А.

Фролова Н.С.

Фролов А.А.

Фролов А.В.

Фундератов Ю.В.

Хардикова Р.И.

Харитонов С.П.

Хартиев C.M.

Харьковский В.М.

Хлопцева Е.В.

Христиансен Й.Ш.

Хруцкий B.M.

Цветкова И.В.

Цыганкова А.Е.

Чавгун A.C.

Часовников В.К.

Челинцев Н.Г.

Чепыженко А.И.

Чернецкий А.Д.

Черникова Г.Г.

Черничко И.И.

Чернова Н.В.
$1355,1398,1505-1507$

1217

1324

753

29,34

135,186

556

290-292

216

1458,1610

$136,370,376,419,420-425,434,466,467,478$, $479,493-495,1612$

1067

$370,375,425,434,444,466,467,478,479$, 490-492, 1632

1236,1237

1233

1236,1237

843,910

175

$174,178,1391$

1236,1237

667

1233,1234

1237

204, 218, 219, 223, 1615

1233-1237

1276

979, 1009

1239

978, 981

1336

910

706 


\begin{tabular}{ll} 
Черноиванова Л.А. & 705 \\
Чикилев В.Г. & 705 \\
Чикин А.Л. & $188,189,206-208,216$ \\
Чинарина А.Д. & $25-28,1551,1613$ \\
Чмаркова Г.М. & 959 \\
Чупин И.И. & 813,1147 \\
Чупрова М.М. & 1236,1237 \\
Чупрова Н.И. & $1233-1237$ \\
Чухарева И.П. & 843 \\
Шавыкин А.А. & $448,831,865,948,1228,1310,1322,1329,1364$, \\
& $1372,1380-1382,1400,1401,1424,1428-1430$, \\
& $1433-1437,1447,1478,1494,1496,1504,163$, \\
& 1643 \\
Шаманский С.В. & 1234,1235 \\
Шандарова Ю.В. & 1235,1237 \\
Шаповалова С. & 1616 \\
Шахова И.Н. & $1233,1234,1236,1237$ \\
Шевердяев И.В. & $165,188,189,204,216,218,219,1611,1615$ \\
Шевченко В.Н. & 1336 \\
Шержуков Е.Л. & 216 \\
Шиков А.Н. & 1510 \\
Шилин М.Б. & 1429 \\
Шиловский А.В. & 1236,1237 \\
Шипилова О.Г. & 1233 \\
Шипилов Э.В. & $45,92-98$, \\
Широколобова Т.И. & $231,244,247-250,262,263,293$ \\
Широколобов Д.В. & 137,138 \\
Ширшова О.Н. & 1237 \\
Шитова М.В. & 1147 \\
Шишкина А.В. & $182,215,220$ \\
Шкарубо С.И. & 97,98 \\
Шкляревич Г.А. & 869,870 \\
Шлыкова В.В. & 29,34 \\
Шмараева А.Г. & 1616,1619 \\
\hline
\end{tabular}


Шохин И.В.

Шошина Е.В.

Шулина М.B.

Щепак Л.В.

Эриксен Е.

Юлипети Я.

Юрьева О.А.

Яицкая Н.А.

Яковлев А.П.

Ясакова О.Н.

Яшкина А.А.

Aakra K.

Aarvik L.

Abdurahmanov G.M

Alekseeva L.

Allen I.

Alieva S.V.

Amin A.B.

Anisimova N.A.

Anker-Nilssen T.

Arcy J.D.

Ávila-Jiménez M.L.

Avilov K.

Babenko A.

Bagheri S.

Badanin Yu.A.

Barrett R.T.

Bartnicki J.

Basin A.B.

Bauch H.A.

Bellerby R.

Belikov S.E.

Belkina O.A.
$372,373,450,455,465,496,776-778,781,782$, 1311,1620

618

1233-1235

$751,754-757,1218,1219,1608$

695

1385

$1235-1237$

166, 190, 204, 216-221, 1372, 1615, 1634

1199

1276

$1234,1235,1237$

1293

1293

513

1419

226, 229

513

1220,1224

510

956

1221

1293

1509

1293

300

957

956

1406-1409

511

99, 100, 102, 105, 108

225, 226, 229

1419

791 


\begin{tabular}{|c|c|}
\hline Belkovich V. & 1410 \\
\hline Bender M. & 722 \\
\hline Berchenko I.V. & 347,1290 \\
\hline Berdnikov S.V. & $228,1621,1622$ \\
\hline Berge J. & $718-722$ \\
\hline Bespalova L.A. & 1284 \\
\hline Biersma E.M. & 1293 \\
\hline Birkjedal I. & 707 \\
\hline Biryukova S.V. & 511 \\
\hline Bogdanova M.I. & 956 \\
\hline Bogus K. & 300 \\
\hline Boltunov A.N. & 1419 \\
\hline Boniecki P. & 512 \\
\hline Boström S. & 1293 \\
\hline Bouchard P. & 802 \\
\hline Boulinier T. & 956 \\
\hline Bousquet $Y$. & 802 \\
\hline Bracher A. & 193 \\
\hline Brewin R. & 226,229 \\
\hline Brittain J.E. & 1293 \\
\hline Brown R.J. & 711 \\
\hline Bruun J. & $225,226,229$ \\
\hline Brykov V.A. & 711 \\
\hline Bulysheva N.I. & 1327 \\
\hline Butenschön M. & 226,229 \\
\hline Byrkjedal I. & $708,715,727$ \\
\hline Carlsson A.M. & 1293 \\
\hline Chaban E.M. & 497-499 \\
\hline Chardine J.W. & 956 \\
\hline Chastel O. & 956 \\
\hline Chernetsky A. & 1410 \\
\hline Christoffersen K. & 1293 \\
\hline Chivers L.S. & 956 \\
\hline Christensen G. & 711 \\
\hline
\end{tabular}


Christensen-Dalsgaard S. $\quad 956$

Christiansen J.S.

$632,707,709,711,713,715-722,724,725,727$

Christoffersen $\mathrm{K}$.

711

Clément-Chastel C.

956

Coad B.W.

716

Colhoun K.

956

Convey P.

1293

Cott P.

711

Coulson S.J.

783, 791, 806, 949, 1035, 1293

Crane P.

711

Daunt F.

956

Deart Yu.V.

500,523

Dempson J.B.

711

Denisov V.V.

191

De Smet W.H.

1293

Dikaeva D.R.

514

Docker M.

711

Dolgov A.

1291

Druzhkova E.I.

224, 294, 295, 298, 299, 1290

Dubinenkov I.

193

Duhno G.N.

227

Dunaevskaya E.

1221

Dunmall K.

711

Durant J.M.

1291

Dvoretsky A.G.

350-363, 502-509, 710

Dvoretsky V.G.

$347-363,503-509,710$

D'yakov N.N.

1621,1622

Dzhenyuk S.L.

191, 192, 195, 197, 1281-1283, 1286, 1621, 1622

Eikelmann I.M.

1412

Ekrem T.

1293

El'derkhanova Z.M.

513

Eriksen E.

726

Ermolaev A.I.

953,954

Erséus Ch.

783,806

222 


\begin{tabular}{|c|c|}
\hline Eskendarova S.N. & 513 \\
\hline Ezhov A.V. & 957 \\
\hline Fagerheim K.-A. & 1010 \\
\hline Farion D.A. & 1402 \\
\hline Fedotova L.V. & 1222 \\
\hline Fedorkova Yu.V. & 227 \\
\hline Feduhina T.Ya. & 114 \\
\hline Fedyuk M. & 1287 \\
\hline Fevolden S.-E. & 724 \\
\hline Fjellberg A. & $783,791,806,1293$ \\
\hline Finstad A. & 711 \\
\hline FitzGerald R.D. & 1221 \\
\hline Flint M.V. & 299 \\
\hline Fokin M. & 1287 \\
\hline Fomin V.V. & 1621,1622 \\
\hline Frantzen M. & $717-722$ \\
\hline Frie A.K. & $1010-1012,1014$ \\
\hline Freeman R. & 956 \\
\hline Frederiksen M. & 956 \\
\hline Frolova E.A. & $514,1282,1283$ \\
\hline Frolov A.A. & 500 \\
\hline Füreder L. & 1293 \\
\hline Gallucci V.F. & 711,725 \\
\hline Garbul E.A. & 510 \\
\hline Gaston A.J. & 956 \\
\hline Gavrilo M.V. & 1423 \\
\hline Glöer P. & 529 \\
\hline Gonçalves-Araujo R. & 193 \\
\hline González-Solís J. & 956 \\
\hline Goryaeva A.A & 950 \\
\hline Goryaev Yu.I. & 950,957 \\
\hline Gottschalk J. & 102 \\
\hline Goutte A. & 956 \\
\hline Greenacre M. & 724 \\
\hline
\end{tabular}


Grémillet D. 956

Grigorenko K.S. $\quad 194$

Gromov M.S. $\quad 196$

$\mathrm{Gu} \mathrm{H.} \quad 300$

Gudimov A. $\quad 528$

Guilford T. 956

Gustafsson D. 1293

Gwiazdowicz D.J. 783, 791, 806, 1035, 1293

Gwynn J.P. $\quad 1406-1409,1412,1418$

Halvorsen I. $\quad 719,721$

Hammar J. 711

Hammill M.O. $\quad 1010,1011$

Hansen L.O. 1293

Harris L.N. $\quad 711$

Heard J. 229

Haug T. 726, 1012, 1014

Hauksson E. 1011

Hedges K.J. $\quad 716$

Heim B. 193, 298

Heino J. 711

Holmstrup M. 1293

Hullé M. 1293

Il'in (Ilyin) G.V. 1403, 1413, 1414

Ilyina L.P. 1292

Inzhebeikin Yu.I. $\quad 1415$

Iospje M. 1406-1409

Ishkulova T.G. $\quad 1290$

Ivanova S.A. $\quad 1524$

Ivanov E. 711

Ivlieva O.V. $\quad 1284$

Jeansson E. 225, 226, 229

Jensen G.H. $\quad 956$

Johannessen J. 226, 229

Jones M.K. 1036, 1037, 1040 


\begin{tabular}{|c|c|}
\hline Jørgensen L.L. & 501 \\
\hline Kaczmarek Ł. & 1293 \\
\hline Kalinka O.P. & 1438,1439 \\
\hline Kaliszewicz A. & 512 \\
\hline Kandiano E. & 102 \\
\hline Kantor Yu.I. & 522 \\
\hline Karamushko L.I. & $712,713,717-722$ \\
\hline Karamushko O.V. & $\begin{array}{l}707-709,711,714-716,724,725,727,1282, \\
1283,1286\end{array}$ \\
\hline Karlsen A. & 1221 \\
\hline Karnatov A.N. & 1438,1439 \\
\hline Kapel F.O. & 1010 \\
\hline Kariakin (Karyakin) Yu.V. & 107,110 \\
\hline Kasatkina N.E. & $\begin{array}{l}1402-1409,1411,1412-1414,1417,1418 \\
1420-1422\end{array}$ \\
\hline Kavtsevich N.N. & 1204,1205 \\
\hline Kazanin G.S. & 103,114 \\
\hline Khar'kovskii V.M. & 194 \\
\hline Keskin B. & $784,785,798$ \\
\hline Kirillov A. & 711 \\
\hline Kirejtshuk A.G. & $786,787,799$ \\
\hline Klein H. & $1406-1409$ \\
\hline Klochkov D.N. & 1621,1622 \\
\hline Klyuvitkina $\mathrm{T}$. & 99,100 \\
\hline Kokin O. & 104 \\
\hline Kolicka M. & 1293 \\
\hline Kolomeitsev S.G. & 955 \\
\hline Kolyuchkina G.A. & 511 \\
\hline Kondakov A.A. & 1200 \\
\hline Korneva J.V. & $1036,1037,1040$ \\
\hline Kornienko S.A. & 1040 \\
\hline Korsun S. & 1287 \\
\hline Kovaleva G.V. & 106,1280 \\
\hline Kozyrenko E.A. & 1223 \\
\hline
\end{tabular}


Kraberg A.C.

Krasnova E.

Krasnova V.

Krasnov Yu.V.

Krasnorutskaya K.

Kremp A.

Kreneva K.V.

Kreneva S.V.

Kropyanko L.V.

Kruts A.A.

Kucheryavyy A.

Kuklina M.M.

Kuklin V.V.

Kulygin V.V.

Kumpan S.V.

Lakka H.-K.

Langhelle G.

Larionov V.V.

Lauth R.R.

Lehtonen $\mathrm{H}$.

Lebedeva N.V.

Leppänen A.-P.

Lillig M.

Lind Y.

Lindstrøm U.

Lobkovsky L.I.

Lockyer C.

Loeder M.J.G.

Lomadze N.Kh.

Lorentsen S.-H.

Luchin V.A.

Lygre $\mathrm{K}$.

Lynghammar A.
193, 298

1423

1410

$527,951,956,957,1291,1423$

106

300

1328

1328

1284

1621,1622

711

1039, 1201

1036-1038, 1040, 1201, 1293

$228,1621,1622$

1621,1622

1293

707

295, 297

716

711

783, 788-791, 804, 806, 949, 952-955, 1035, 1285, 1292,1293

1405-1409, 1412, 1417, 1418, 1420-1422

800

1011

1291

101

1010,1011

298

954, 955

956

1621,1622

226, 229

$707,711,715,716,725$

226 
Lyubina (Lubina) O.S.

Lyubin (Lubin) P.A.

Mackee A.

MacPhee S.A.

Madsen M.L.

Maguire J.

Majewski A.R.

Makarevich P.R.

Makarova M.N.

Makarova O.

Makarov A.

Makarov M.V.

Malavenda S.

Mallory M.L.

Manushin I.E.

Maraldo K.

Matushkin N.Yu.

Matishov D.G.

Matishov G.G.

Matsuoka K.

McKiver W.

Mecklenburg C.W.

Meier S.

Melekhina E.N.

Mertens K.N.

Metelkin D.V.

Mesheriakov N.I.

Mikhaylyuk A.L.

Miko L.

Minzyuk T.V.

Moiseev D.V.
$501,514,1282,1283,1286,1287$

$499,501,523$

719,721

716

724

1221

716

224, 294-297, 1280, 1286

1523

1293

1423

619-622, 1440

1287

956

500

$783,806,1293$

101

$1280,1288,1289,1417,1421$

106, 114, 191, 192, 194-197, 300, 758, 958, 1013,

$1202,1281-1284,1286,1288,1289,1327,1402$,

1403, 1406-1409, 1414-1417, 1420-1422, 1552, 1621,1622

300

226, 229

$708,709,711,715,716,725$

$717-722$

$783,791,806,1035,1293$

300

101

113

1202,1203

783,806

1204

191-193, 195-197, 224-229, 296, 297, 1281-1283 
Moe B.

Monteiro P.

Møller B.

Møller P.R.

Moller P.D.R.

Muir D.C.

Mueter F.J.

Mustonen T.

Nabozhenko M.V.

Nahrgang J.

Nalbandyan A.

Nedreaas K.H.

Nekhaeva A.A.

Nekhaev I.O.

Nel A.

Nenasheva-Zheludkova A.I.

Newell M.

Nikolaeva N.G.

Nikolaev S.

Nilssen J.

Nissi M.

Novenko E.

Obluchinskaya E.D.

Ognetov G.N.

Oleinik (Oleynik) A.A.

Oleinik A.G.

Oleynikov E.P.

Olejniczak I.

Olsen B.

Ottesen O.H.

Ovsepyan Ya.

Ødegaard F.

Paatero J.

Pachomov M.V.
956

226, 229

1406-1409, 1412, 1418

$708,715,725$

711

1419

716

711

$511,513,784-787,792-802,805,1327$

$717-722$

1404, 1405-1409, 1411, 1412, 1418

727

803

$497-499,515-524,529,803$

786,787

1205

956

1291,1423

$99,100,102$

1418

1405-1409

106

1523-1529

1013,1552

224, 1290

711

1200

512

956

1220-1222, 1224, 1226

99, 100, 102, 105, 108

1293

1404, 1405-1409, 1411

1203 


\begin{tabular}{|c|c|}
\hline Panteleeva N.N. & 512 \\
\hline Paramonova M. & 115 \\
\hline Pavelskaya E. & 1414 \\
\hline Pavlova L.V. & 525,526 \\
\hline Philibert R. & 225 \\
\hline Phillips R.A. & 956 \\
\hline Pilskog H.E. & 1293 \\
\hline Plotnikov V.V. & 1621,1622 \\
\hline Pogodina I. & $99,100,102,105,108$ \\
\hline Poloskin A. & 1287 \\
\hline Polshin (Pol'shin) V.V. & $106,194,1327,1416$ \\
\hline Poltavskaya M.P. & 790 \\
\hline Ponomareva E.N. & 758 \\
\hline Ponomarev A.V. & 804,1292 \\
\hline Popov A. & 1423 \\
\hline Power M. & 711 \\
\hline Povazhnyi V.V. & $194,1280,1327,1621,1622$ \\
\hline Pozhariskaya O.N. & 1523,1524 \\
\hline Pronin N.M. & 1040 \\
\hline Purchart L. & 805 \\
\hline Præbel K. & 724 \\
\hline Primicerio R. & 724 \\
\hline Proschwitz T. von & 529 \\
\hline Racault M.-F. & 226,229 \\
\hline Rasilainen $\mathrm{T}$. & $1406-1409,1411,1412,1418$ \\
\hline Raskhozheva E.V. & 723 \\
\hline Rebours C. & 1221 \\
\hline Rees A. & 225 \\
\hline Regel K. & 527 \\
\hline Reiersenf L.-O. & 1419 \\
\hline Reinikainen K. & $1404-1409,1411$ \\
\hline Reist J.D. & 711,716 \\
\hline Reshetnikov Y.S. & 711 \\
\hline Risto M. & 1404 \\
\hline
\end{tabular}


Romanov V.I.

Rostovtseva Yu.

Rudenko O.

Ryzhik (Rizhik) I.V.

Salmova N.A.

Samuelsen A.

Samsonov P.

Sandlund O.-T.

Sapozhnikov F.V.

Savinova $T$.

Savinov V.

Savitskii (Savitsky) R.M.

Sawatzky C.D.

Sawicki M.

Sazhin A.F.

Schatz H.

Schiøtte T.

Schlykova V.V.

Schmelz R.M.

Selifonova Zh.P.

Semin V.L.

Seniczak A.

Seniczak S.

Sergeeva V.M.

Sergienko L.

Shatohin B.M.

Shavykin A.A.

Shaw D.

Shchepak L.V.

Sheverdyaev I.V.

Shikov A.N.

Shipilov E.V.

Shokhin I.V.

Shunatova N.
711

102

105,109

$621,622,1440$

759,1223

226, 229

1410

711

1327

1419

1419

958, 1292, 1415

711,716

512

299

783, 806

524

114

783, 806

364

511,1327

791

791

299

1423

1621, 1622

1438, 1439, 1509

956

$760,1225,1226$

1621, 1622

1523,1524

101, 107, 110

513, 1327

1287 
Sikorski A.V. $\quad 526$

Simakova U.V. $\quad 511$

Simon J.C. 1293

Simonov V.A. $\quad 107$

Sklyarov E.V. $\quad 107$

Smolyar I.V. $\quad 1621,1622$

Sohlenius B. 1293

Soier V.G. 194

Solatie D. $\quad 1404,1405,1411,1417,1420-1422$

Solhøy T. 783, 806, 1035, 1293

Somerfield P. 225, 226, 229

Søli G. $\quad 783,806,1293$

Spiridonov V.A. $\quad 511,1327,1423$

Stedmon C.A. 193

Steen H. 956

Stenman O. 1011

Stenson G.B. $\quad 1010,1012,1014$

Stern-Mauritzen M. 1291

Stephens J. 225

Stepanova A.Yu. 99, 100, 105

Stepan'yan (Stepanyan) O.V. 194, 1289

Strelkov P. 1287

Strøm H. $\quad 956$

Stupnikova A. $\quad 347$

Stur E. $\quad 783,806,1293$

Sukhanova I.N. 299

Sukhotin A. $\quad 527$

Swanson K.H. $\quad 711$

Svenning M. 711

Svetocheva O.N. $\quad 726,1011,1016,1419$

Svetochev V.N. 1010, 1012, 1014-1016, 1204, 1410, 1419

Svitina V. 528

Systad G.H. $\quad 956$

Takano Y. 300 
Taldenkova E.

Tanasevitch A.

Tarasov G.A.

Taskaeva A.A.

Tatarinkova L.P.

Teymurov G.A.

Thomalla S.

Thórarinsson T.L.

Tichý V.

Travin A.V.

Tret'yakova I.A.

Treasurer J.W.

Tsygankova A.E.

Uiblein F.

Usiagina (Usyagina) I.S.

Usov N.

Vaaramaa K.

Vakul'skaya N.M.

Vashchenko P.S.

Vedenev A.

Velle G.

Venger M.P.

Verbitskyi E.V.

Verbitskyi R.E.

Vernikovskaya A.E.

Vernikovsky V.A.

Vichi M.

Vinarski M.V.

Vines A.

Vira J.

Voinov V.B.

Voskoboinikov G.M.

Waldron $\mathrm{H}$.

Wasbotten I.
$99,100,102,105,108$

1293

$103,109,111-115$,

$789,791,1293$

950

513

$225,226,229$

956

801

107

1621,1622

1221

1621,1622

727

1402, 1403, 1406-1409, 1412-1414, 1416, 1418

1287

$1404-1409,1422$

1621,1622

1438,1439

1509

1293

1290

1200, 1327

1327

101

101

226, 229

524,529

229

1406-1409

1200, 1202, 1203

620-622, 1440

225, 226, 229

$717,718,720,722$ 


$\begin{array}{ll}\text { Weinerroither R.M. } & 727 \\ \text { Wiltshire K.H. } & 298 \\ \text { Wrona F.J. } & 711 \\ \text { Yaitskaya N.A. } & 1621,1622 \\ \text { Yamaguchi A. } & 300 \\ \text { Yerokhina I.A. } & 1206 \\ \text { Ylipieti J. } & 1406-1409 \\ \text { Zakharenko V. } & 115 \\ \text { Zacharov D.V. } & 501 \\ \text { Zalota A.K. } & 1327 \\ \text { Zawierucha K. } & 1293 \\ \text { Zhichkin A.P. } & 191,192,195-198,230,1281-1283,1621,1622 \\ \text { Zhuravleva N.G. } & 759,760,1220-1226 \\ \text { Zimina O.L. } & 501 \\ \text { Zmudczyńska-Skarbek K. } & 1293 \\ \text { Zolotareva A.E. } & 1280,1327\end{array}$




\section{СОДЕРЖАНИЕ}

Стр.

История исследований. Юбилейные даты ............................. 5

Геология. Седиментология. Палеоэкология .......................... 8

Гидрология. Гидрохимия. Метеорология …......................... 18

Моделирование. Информационные технологии ...................... 27

Гидробиология ................................................... 32

Микробиологические сообщества .............................. 32

Фитопланктон. Первичная продукция ........................... 36

Зоопланктон ............................................... 41

Зообентос .............................................. 47

Водоросли-макрофиты, водная растительность ................. 67

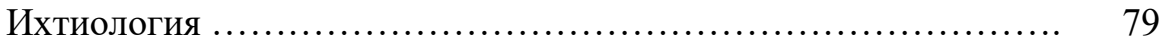

Аквакультура .............................................. 90

Энтомология …................................................. 95

Птицы ............................................................ 99

Морские млекопитающие .......................................... 116

Паразитология .................................................... 123

Физиология и биохимия ….......................................... 125

Гистология и цитология .............................................. 146

Общие вопросы экологии арктических и южных морей ................ 150

Мониторинг водных экосистем ..................................... 158

Антропогенное загрязнение водных экосистем и охрана природы ..... 162

Оценка воздействия на окружающую среду при освоении нефтегазовых месторождений ............................................... 174

Устойчивое развитие прибрежных экосистем и экологическая

безопасность ................................................. 177

Технология переработки гидробионтов и водорослей …............. 185

Монографии …................................................. 187

Сборники статей, материалы конференций ......................... 189

Учебно-методические издания ..................................... 191

Информационные издания ........................................... 193

Препринты ......................................................... 194

Карты. Атласы. Альбомы. Каталоги. Определители ..................... 195

Авторефераты кандидатских и докторских диссертаций ............... 196

Патенты ............................................................. 197

Научно-популярные книги и статьи .................................. 199

Авторский указатель ............................................ 200 
CONTENTS

\begin{tabular}{|c|c|}
\hline & \\
\hline & \\
\hline ogy . & \\
\hline ation technologies. & \\
\hline 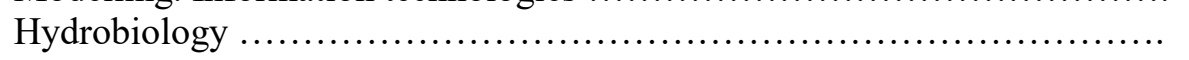 & \\
\hline bial communities & \\
\hline Phytoplankton. A primary production & \\
\hline 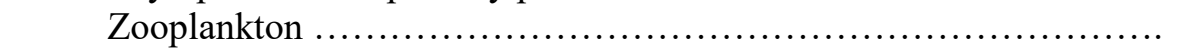 & \\
\hline Zoob & \\
\hline Alga & \\
\hline Ichth & \\
\hline & \\
\hline atomology & \\
\hline irds & \\
\hline Lari & \\
\hline .. & \\
\hline .. & \\
\hline istc & \\
\hline and southern seas & \\
\hline ....... & \\
\hline tection ........ & \\
\hline osits ... & \\
\hline afety ... & \\
\hline and algae . & \\
\hline Mor & \\
\hline erences & \\
\hline Traini & \\
\hline . & \\
\hline ..... & \\
\hline 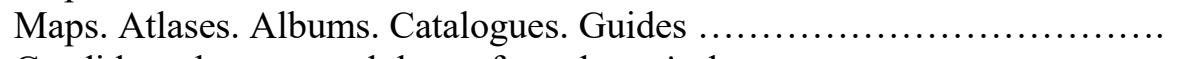 & \\
\hline 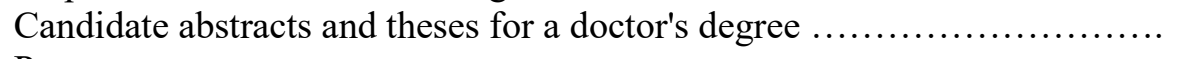 & \\
\hline ..... & \\
\hline & \\
\hline . & \\
\hline
\end{tabular}


БИБЛИОГРАФИЧЕСКИЙ УКАЗАТЕЛЬ

РАБОТ СОТРУДНИКОВ

МУРМАНСКОГО МОРСКОГО

БИОЛОГИЧЕСКОГО ИНСТИТУТА

(2011-2015 гг.)

Технический редактор С.В. Тимофеева

Компьютерная верстка Н.Ю. Иванова

Фото на обложке: О.Л. Зимина

Утверждено к печати

Ученым советом Мурманского морского биологического института

Кольского научного центра Российской академии наук

Подписано к печати 14.02.2020.

Формат бумаги 70x108 1/16.

Бумага офсетная. Печать офсетная. Гарнитура Times/Cyrillic.

Уч.-изд.л. 20,65. Заказ № 13. Тираж 100 экз. 
